\author{
UNIVERSITY OF SÃO PAULO \\ SÃO CARLOS SCHOOL OF ENGINEERING \\ PROGRAM IN HYDRAULIC AND SANITARY ENGINEERING
}

ALTAIR ROSA

BIORETENTION FOR DIFFUSE POLLUTION CONTROL IN SUDS USING EXPERIMENTAL-ADAPTIVE APPROACHES OF ECOHYDROLOGY

CORRECTED VERSION (VERSÃO CORRIGIDA)

SÃO CARLOS

2016 



\section{ALTAIR ROSA}

\section{BIORETENTION FOR DIFFUSE POLLUTION CONTROL IN SUDS USING EXPERIMENTAL-ADAPTIVE APPROACHES OF ECOHYDROLOGY}

Doctoral thesis presented to the São Carlos School of Engineering, University of São Paulo in partial fulfilment of the requirements for the degree of Doctor of Science in the subject of Hydraulics and Sanitary Engineering

Advisor: Prof. Dr. Eduardo Mario Mendiondo

Co - advisor: Prof. Dr. Vladimir Caramori Borges de Souza

\section{SÃO CARLOS}


AUTORIZO A REPRODUÇÃO TOTAL OU PARCIAL DESTE TRABALHO, POR QUALQUER MEIO CONVENCIONAL OU ELETRÔNICO, PARA FINS DE ESTUDO E PESQUISA, DESDE QUE CITADA A FONTE.

R788b Rosa, Altair

BIORETENTION FOR DIFFUSE POLLUTION CONTROL IN SUDS

USING EXPERIMENTAL-ADAPTIVE APPROACHES OF ECOHYDROLOGY / Altair Rosa; orientador Eduardo Mario Mendiondo; coorientador Vladimir Caramori Borges de Souza. São Carlos, 2016.

Tese (Doutorado) Programa de Pós-Graduação em Engenharia Hidráulica e Saneamento e Área de Concentração em Hidráulica e Saneamento Escola de Engenharia de São Carlos da Universidade de São Paulo, 2016 .

1. Sustainable urban drainage. 2. Compensatory techniques sizing. 3. Diffuse pollution. I. Título. 


\section{FOLHA DE JULGAMENTO}

Candidato: Engenheiro ALTAIR ROSA.

Título da tese: "Bioretenção para o controle da poluição difusa em drenagem urbana sustentável (SUDS) utilizando abordagens experimentais-adaptativas de ecohidrologia".

Data da defesa: 24/1 1/2016.

\section{Comissão Julgadora:}

Prof. Dr. Eduardo Mario Mendiondo

\section{(Orientador)}

(Escola de Engenharia de São Carlos/EESC)

Prof. Dr. Vladimir Caramori Borges de Souza

(Universidade Federal de Alagoas/UFAL)

Dr. Wilson Tadeu Lopes da Silva (EMBRAPA)

Prof. Dr. Marllus Gustavo Ferreira Passos das Neves (Universidade Federal de Alagoas/UFAL)

Prof. Dr. Nilo de Oliveira Nascimento

(Universidade Federal de Minas Gerais/UFMG)

Coordenadora do Programa de Pós-Graduação em Engenharia Hidráulica e Saneamento:

Profa. Associada Maria Bernadete A. Varesche Silva

Presidente da Comissão de Pós-Graduaçdo:

Prof. Associado Luis Fernando Costa Alberto

\section{Resultado:}
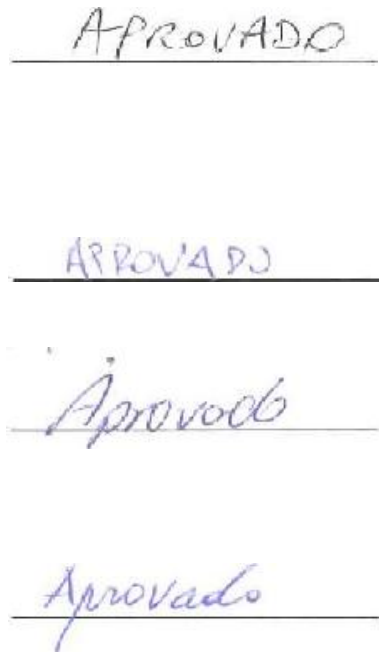

Arnovaso 
DEDICATION

To my parents, Mr. Jorge de Lara Rosa and Mrs. Maria Rega de Lara Rosa and to my best friend Wilson José Galheira who in their own way, at all times, were present, always being my personal support. 


\section{ACKNOWLEDGMENTS}

Deep gratitude to Professors Eduardo Mario Mendiondo, Vladimir Caramori Borges de Souza and David Sample for the tireless guidance and patience with the discussions and for the friendship, encouragement and help in the difficult times faced in this challenge.

To my brothers, nephews, family members and friends for the encouragement and understanding of my absence.

To the NIBH family: each person, in his/her own way and time, helped me to overcome many difficulties. This is especially for arretada Clarissa Câmara de Freitas "Paraíba masculina, Muié macho, sim sinhô", everyone's supermom, always ready to everything and my partner all this time. Thank you very much!

To the two enlightened people, best team that I could ever have: Marina Batalini de Macedo and Cesar do Lago. You are examples of smart, committed and engaged people. Together we managed our experiments "BIRENICE and GODOFREDO". With you, I learned, challenged myself and grew up. My eternal gratitude for all the shared moments!

To the team Life Long Workout (God Team)! You are more than special people to me. You held, listened to and supported me in my sad and happy moments during the period in São Carlos, always willing to comfort me with some training and at Tomodaty or with barbecues on weekends. Friends who I want to have forever, my sincere thank you. Remember, Curitiba is right around the corner, I will be waiting you all there!

To the sweetest couple, Gisela and Tomás, for the friendship, support and encouragement.

To professor Fabiana de Nadai Andreoli and PUCPR, for the trust placed in me and all the support on this journey. Thank you very much!

To my great friend and adviser, Wilson José Galheira, for the friendship, support and encouragement. You will always be my personal and professional references.

To my friends Mariana Kitamura and Henrique Lima, who, even from the distance, have always been present along this journey.

Special thanks to my favorite baiana monster, Mariana Rivera Freire, for the help, care and dedication.

To Sá and Priscilla, efficient secretaries of PPGSHS, for all the attention and understanding. 
In memory of my dear friend, Marcelo Bronze, for the support, encouragement, conversations and laughter. The one who reminded me almost daily the 3F quote: Strength $($ Força), Faith (Fé) and Focus (Foco). You were and always will be remembered. My eternal admiration.

In memory of Dr. Hercília Laura Ferrari Cocicov, for the long conversations and encouragement. Thank you for showing me, in practice, that with work, love and dedication, it is possible to go further. Wherever you are, receive my love, gratitude and admiration.

I thank the University of São Paulo for the physical structure and FAPESP and $\mathrm{CNPq}$ for granting me full scholarship, which made possible to accomplish this $\mathrm{PhD}$.

To all who believed it would be possible to accomplish this journey.

Anyway, to God, responsible for our existence. 


\section{EPÍGRAFE}

"I told you, but I will repeat: not dam a river, do not fool nature, make the dam you want, because the river sooner or later will find a way to tear the earth open a path, and return to run on his bed of origin. "

FERNANDO PESSOA 


\begin{abstract}
ROSA, A. (2016). Bioretention for diffuse pollution control in SUDS using experimental-adaptive approaches of ecohydrology. Doctoral Thesis, São Carlos School of Engineering, University of São Paulo, São Carlos.

Problems of land use and occupation in urban areas may prevent the infiltration of water, thus increasing runoff. Bioretention techniques are solutions, which are emerging from the hydrology field to mitigate the consequences of increasing urbanization, including, flooding and contamination of rivers. The general objective of this research is to study the general efficiency of combined Compensatory Techniques (CT) with detention and bioretention control of diffuse pollutants from an urban drainage system. Specific objectives are defined in each chapter and relates to sizing and to the bioretention systems of modeling and monitoring, located in southeastern Brazil, São Paulo - São Carlos. The first chapter presents the general introduction of the thesis, the objectives and research hypotheses, as well as, the description of the general methodology for the thesis construction and the goals related to each chapter. The second chapter discusses the scope and some limitations of the classifications of terms frequently used in the theme of sustainable urban drainage. This chapter, in a way, approaches the other chapters, which composes this thesis, by providing them comprehensive database of references. The third chapter presents the design criteria used for the construction of experimental bioretention system and compares the design with the model HEC - HMS - Hydrologic Engineering Center - Hydrologic Modeling System. The fourth chapter talks about some criteria to identify areas for building bioretention systems and presents the GIS - Geographic Information System and ecohydrology indicators, in this characterization, considering the quantity and quality aspects in the urban drainage. The fifth chapter shows the use of PCSWMM model (Personal Computer Stormwater Management Model) to simulate future scenarios, assuming progressive modular expansion of CTs, modeling efficiency in qualitative and quantitative aspects diffuse pollution for scenarios 2015, 2025, 2050, 2100. The conclusion of this research is that compensatory techniques can be used not only to assess the impacts of diffuse pollution stemmed from urban drainage system, but as a contribution to the sustainability of watersheds and to mitigation of extremes risks derived by increased urban drainage demand.
\end{abstract}

Palavras-chave: Sustainable urban drainage, Compensatory techniques sizing, Diffuse pollution. 


\section{RESUMO}

ROSA, A. (2016). Bioretenção para o controle da poluição difusa em drenagem urbana sustentável (SUDS) utilizando abordagens experimentais-adaptativas de ecohidrologia. Tese de Doutorado, Escola de Engenharia de São Carlos, Universidade de São Paulo, São Carlos.

Problemas decorrentes do uso e ocupação do solo em áreas urbanas podem dificultar a infiltração da água, aumentando o escoamento superficial. Técnicas de bioretenção são soluções decorrentes do campo da hidrologia para mitigar as consequências resultantes da crescente urbanização, entre elas, enchentes e contaminação de rios. O objetivo geral da pesquisa é estudar a eficiência generalizada de Técnicas Compensatórias (TC's) experimentais, adaptáveis combinadas de detenção e bioretenção para controle da poluição difusa da drenagem urbana. Objetivos específicos são definidos em cada capítulo e relacionam-se com o dimensionamento e monitoramento de modelagem de sistema de bioretenção, localizado no Sudeste do Brasil, São Paulo - São Carlos. O Primeiro capítulo apresenta a introdução geral da tese, objetivos e hipóteses, bem como, descreve a metodologia geral para construção da tese e relação dos objetivos com os respectivos capítulos. O Segundo capítulo discute os alcances e limitações de nomenclaturas sobre termos frequentemente utilizados na temática drenagem urbana sustentável. Este capítulo de certa forma aporta os demais capítulos que compõe esta tese, por propiciar vasto banco de dados referenciais. O Terceiro capítulo apresenta os critérios de dimensionamento utilizados para a construção de um sistema de bioretenção experimental e uma comparação com o dimensionamento com o modelo HEC - HMS - Hydrologic Engineering Center Hydrologic Modeling System. O Quarto capítulo discorre sobre critérios de escolha de áreas propicias para a construção de sistemas de bioretenção usando Sistemas de Informações Geográficas para a caracterização de áreas, utilizando indicadores ecohidrológicos, considerando os aspectos de quantidade e de qualidade na drenagem urbana. O Quinto capítulo demonstra o uso do modelo PCSWMM - Personal Computer Stormwater Management Model, na simulação de cenários futuros assumindo expansões modulares progressivas da TC, modelando a eficiência para os aspectos qualitativos e quantitativos da poluição difusa para os 2015, 2025, 2050, 2100. Conclui-se com esta pesquisa que técnicas compensatórias podem ser empregadas não só para avaliação dos impactos da poluição difusa provindos da drenagem urbana, mas como forma de contribuir com a sustentabilidade de bacias hidrográficas e para mitigação de riscos de extremos advindos do aumento da demanda de drenagem urbana.

Palavras-chave: Drenagem urbana sustentável, Dimensionamento de técnicas compensatórias, Poluição difusa. 


\section{LIST OF FIGURES}

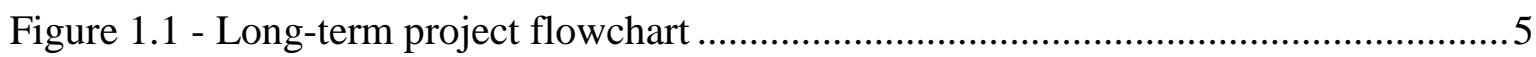

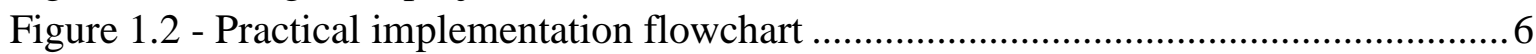

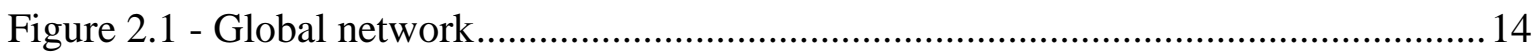

Figure 2.2 - Relationships between authors and countries related to continent ................... 14

Figure 2.3 - Relationships between authors and countries related to countries ................... 15

Figure 2.4 - Centralization of countries in terms of relations between authors ................... 15

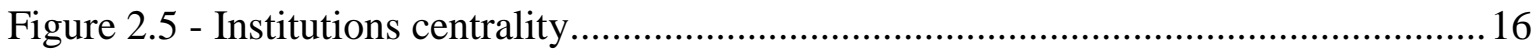

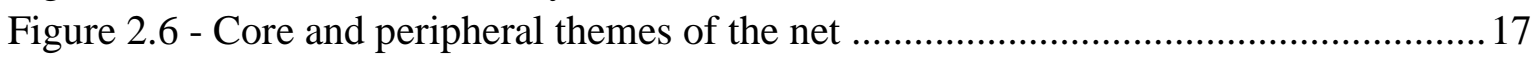

Figure 2.7 - Expressions searched in the Web of Science base .......................................... 18

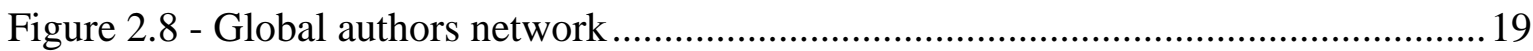

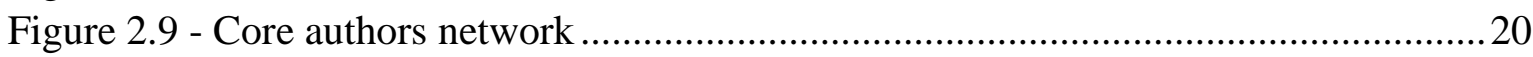

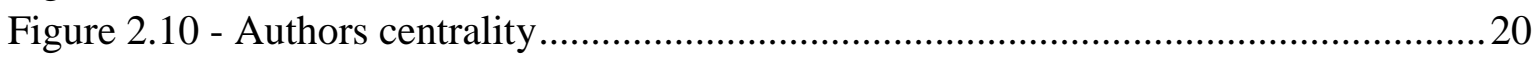

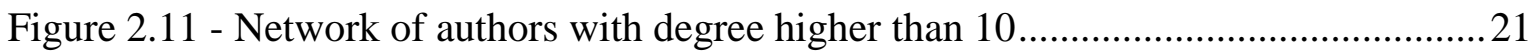

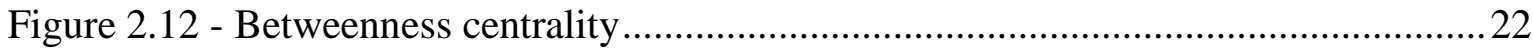

Figure 3.1 - Hydrograms for sizing scenarios and water balance..................................... 31

Figure 3.2 - Graphs showing the increase of capacity of the urban drainage system using

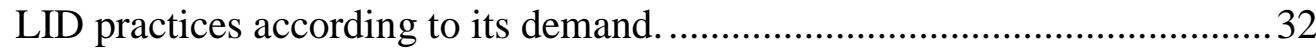

Figure 3.3 - Diagram used for modeling and computational simulation.............................36

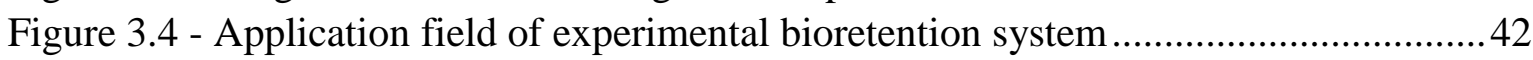

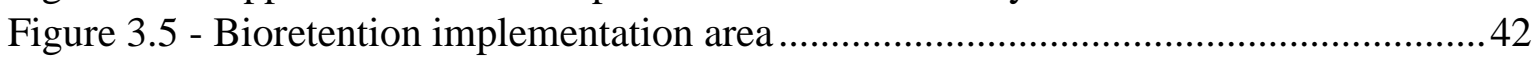

Figure 3.6 - Bioretention dimensions considering modular expansion (in red). ..................46

Figure 3.7 - Internal water dynamics hydrographs and cumulative volumes. .......................47

Figure 3.8 - Comparative inlet hydrographs between BIRENICE (a) and HEC-HMS (b) .48

Figure 3.9 - Internal water dynamics simulation and cumulative volumes ........................ 49

Figure 4.1 - Location map for the Mineirinho's River basin inside São Carlos ....................66

Figure 4.2 - Collecting point for water samples a) input; b) storage, and C) output............68

Figure 4.3 - Use and Occupation - Mapping for 2004, 2010 e 2014 ................................ 70

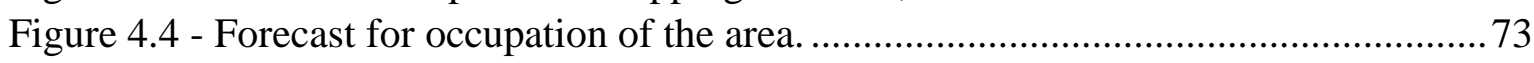

Figure 4.5 - Influence zones and contribution areas for the bioretention technique. ..........74

Figure 4.6 - Perspective for implanting the bioretention technique ................................. 75

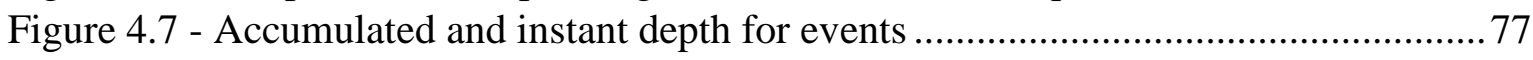

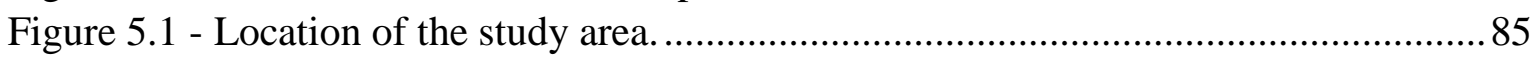

Figure 5.2 - Flowchart of the methodological steps of the research in PCSWMM.............87

Figure 5.3 - Model building scheme based on real scenario data.................................... 88

Figure 5.4 - Results for calibration based on rain-flow profile in bioretention technique .92

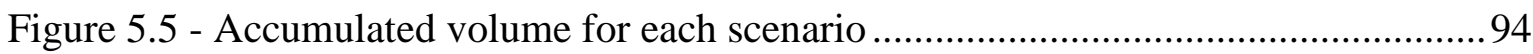

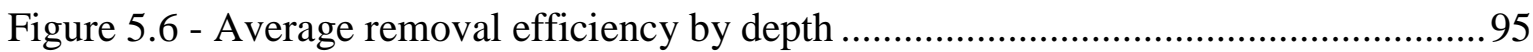

Figure 5.7 - Average Efficiency for scenarios ....................................... 97 


\section{LIST OF TABLES}

Table 2.1 - Expressions searched in the Web of Science base ........................................... 13

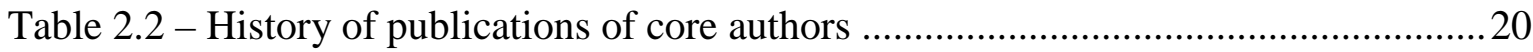

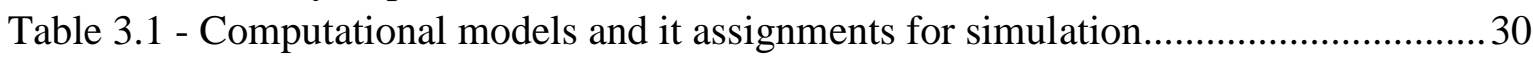

Table 3.2 - Bioretention cell modular sizing for application field .........................................46

Table 3.3 - Peak flow comparison between BIRENICE and HEC-HMS method................48

Table 3.4 - Comparative water balance for both models .................................................50

Table 3.5 - Comparative results of sizing methods (see equations and criteria in the text) 51

Table 4.1 - Time control and collection times of the events..............................................69

Table 4.2 - Evolution of land use at Campus 2 - São Carlos (USP)................................... 71

Table 4.3 - Evolution of land uses in the APPs Campus 2 - São Carlos (USP). .................. 72

Table 4.4 - Evolution of land uses in the RL Campus 2 - São Carlos (USP). ...................... 72

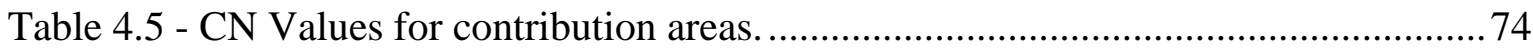

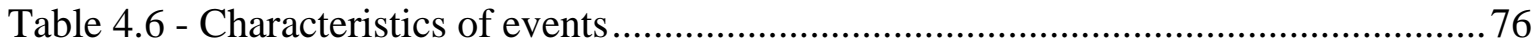

Table 4.7 - Event Mean Concentration for pollutants in each event .................................. 76

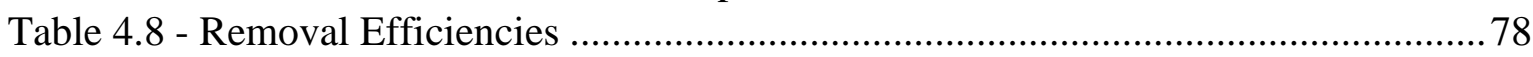

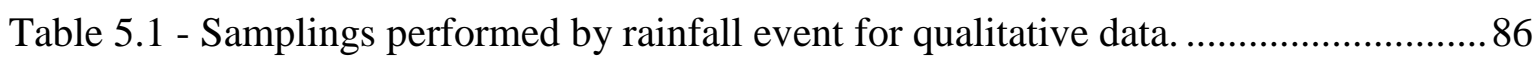

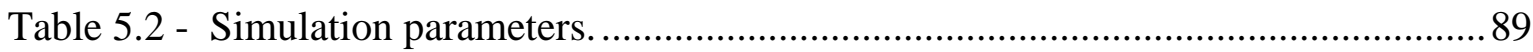

Table 5.3 - Values of calibration coefficients for pollution concentrations in the wash water (Washoff)

Table 5.4 - Values of calibration coefficients for pollution accumulation concentrations

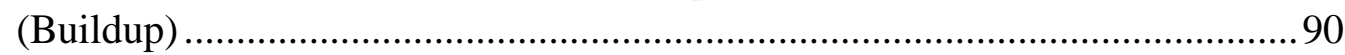

Table 5.5 - Dimensions of bioretention techniques for future scenarios. ............................ 91

Table 5.6 - Rain concentration Galavoti according to method (2010) .................................91

Table 5.7 - Input volumes, output, and infiltration to the simulated scenarios ..................93

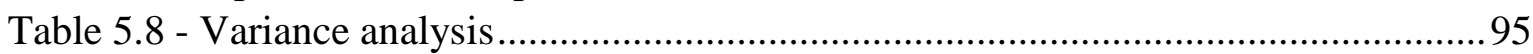

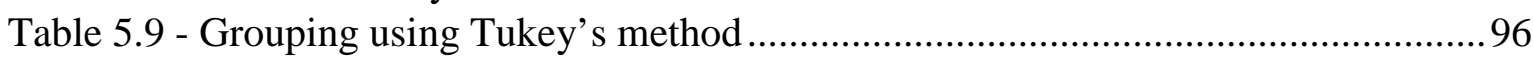

Table 5.10 - Removal efficiency in future scenarios .....................................................96 


\section{LIST OF VARIABLES}

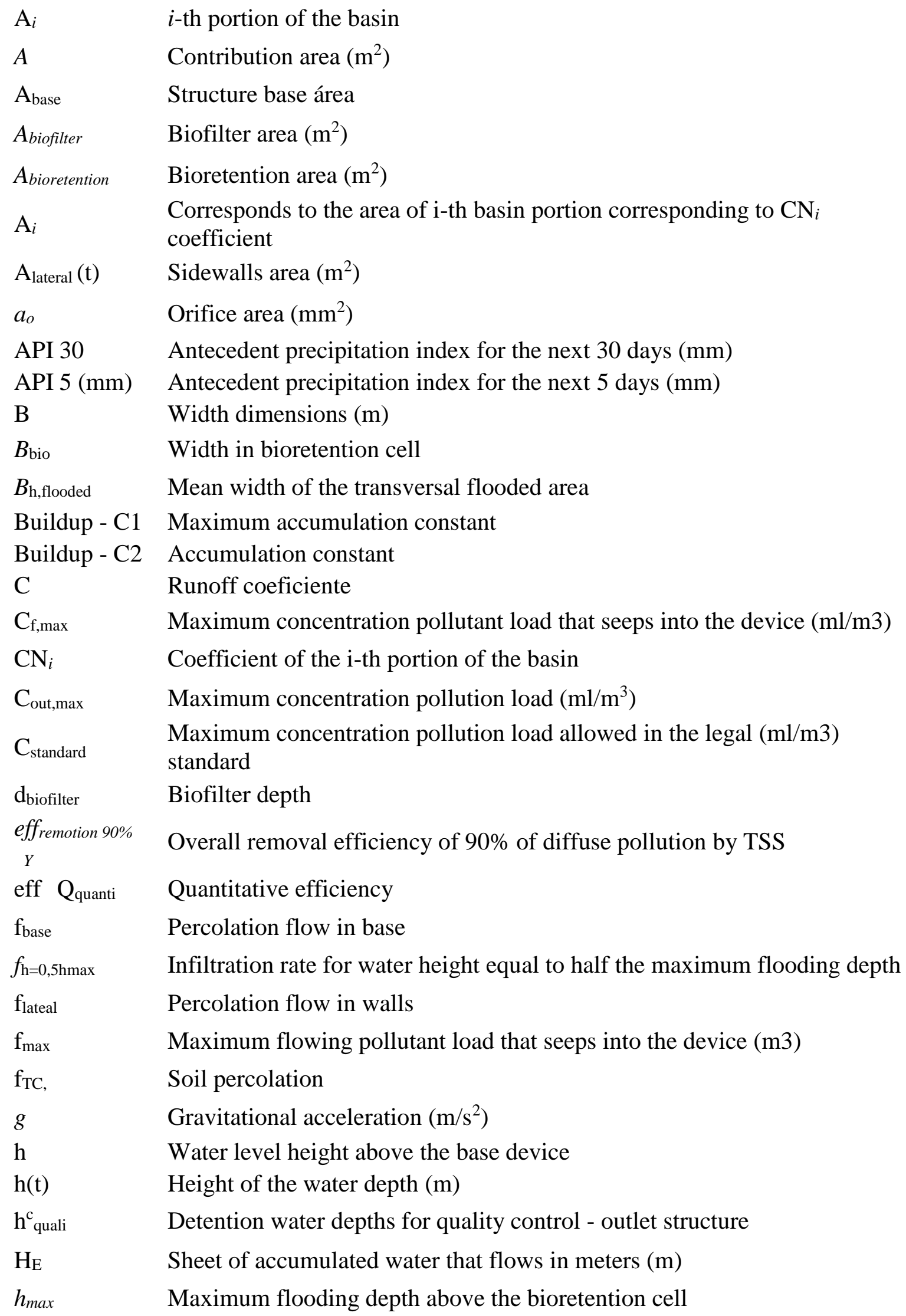




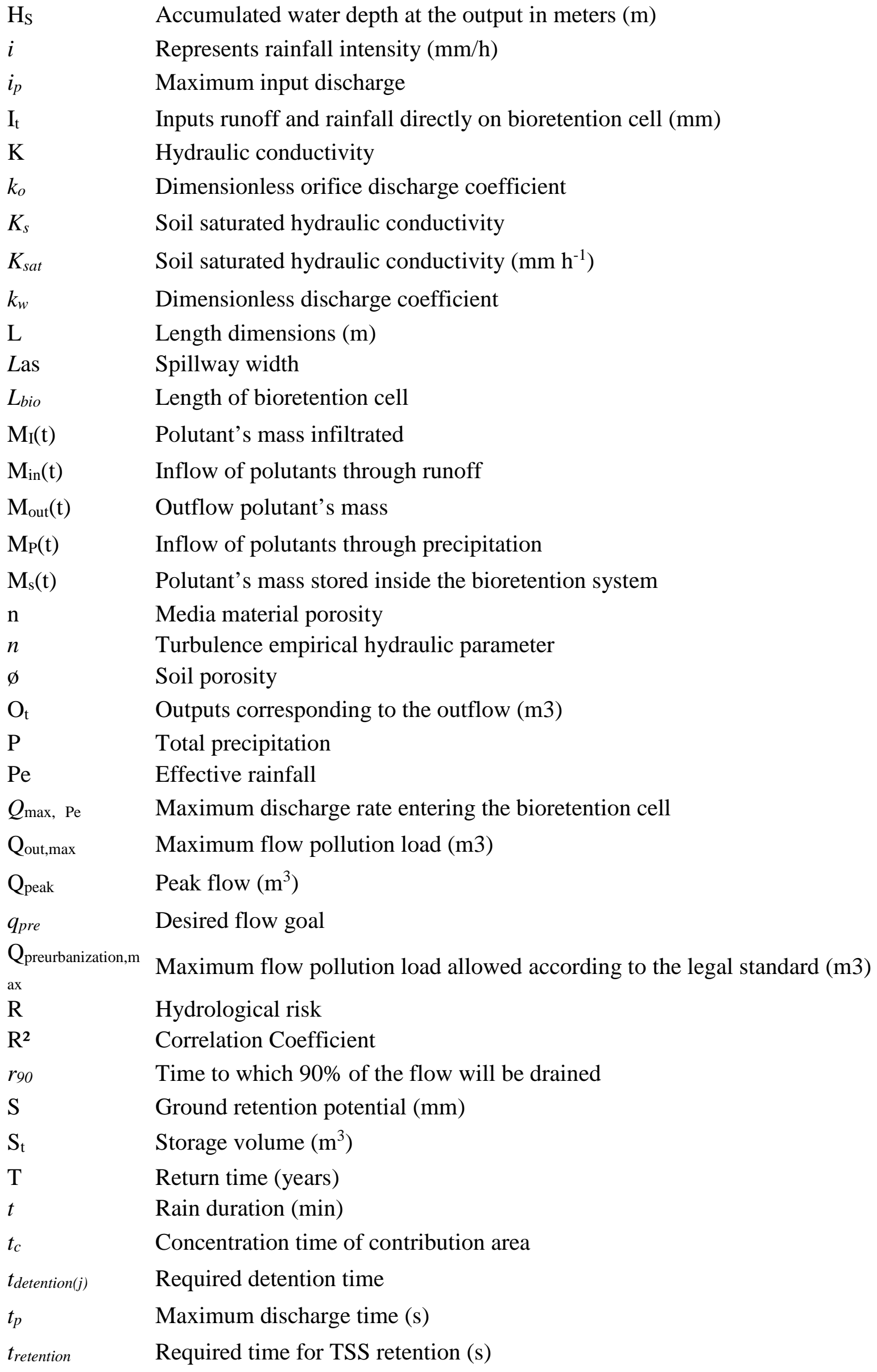




$\begin{array}{ll}\mathrm{t}_{\text {TSS quali-IN }} & \text { Solids mass transport retention time } \\ \mathrm{t}_{\mathrm{TSS} \text { quali-OUT }} & \text { Bioretention draining time } \\ u_{S T T}(\mathrm{j}) & \text { Settling velocity of the TSS } \mathrm{j} \text {-th fraction } \\ \text { Vbioretention } & \text { Total volume of bioretention }\left(\mathrm{m}^{3}\right) \\ \mathrm{V}_{\text {max,quanti }} & \text { Pre-sizing volume (mm height equivalent) } \\ \text { Vmax }_{\text {quali }} . & \text { Extra volume } \\ V_{\text {quali }} & \text { Volume water depths for quality control measured at the outlet structure } \\ w_{90} & \text { Period in which at least } 90 \% \text { of runoff will be held } \\ \text { Washoff - C1 } & \text { Washoff coefficient } \\ \text { Washoff - C2 } & \text { Washoff exponent } \\ \alpha & \text { Infiltration efficiency reduction coefficient due to clogging } \\ \beta & \text { Runoff coefficient with the ratio between percolation area and } \\ \gamma & \text { implementation area } \\ \eta & \text { Ratio between the percolation area and volume (mm) } \\ \Psi & \text { Filler material porosity in porosity units (pu) }\end{array}$




\section{LIST OF ABBREVIATIONS}

$\begin{array}{ll}\text { APP } & \text { Permanent Preservation Areas } \\ \text { BIRENICE } & \text { BIoREteNtIon CEll method } \\ \text { BMP } & \text { Best Management Practices } \\ \text { CAD } & \text { Computer Aided Design } \\ \text { CEMADEN } & \text { National Center for Monitoring and Warning Natural Disasters } \\ \text { CN } & \text { Curve Number } \\ \text { CNPq } & \text { National Counsel of Technological and Scientific Development } \\ \text { CONAMA } & \text { National Environment Council } \\ \text { CPTEC/INPE } & \text { Center of Weather Forecasting and Climate Studies } \\ \text { CT } & \text { Compensatory technique } \\ \text { DEM } & \text { Digital Elevation Model } \\ \text { EESC/USP } & \text { School of Engineering of São Carlos /University of São Paulo } \\ \text { EMC } & \text { Event Mean Concentration } \\ \text { FAPESP } & \text { São Paulo State Research Foundation } \\ \text { GIS } & \text { Geographic Information System } \\ \text { HEC HMS } & \text { Hydrologic Engineering Center - Hydrologic Modeling System } \\ \text { INMET } & \text { National Institute of Meteorology } \\ \text { LID } & \text { Low Impact Development } \\ \text { MAPLU2 } & \text { Stormwater Management in the Urban Environment Project } \\ \text { NSE } & \text { Nash-Sutcliffe Efficiency } \\ \text { PCSWMM } & \text { Personal Computer Storm Water Management Model } \\ \text { PULS } & \text { Level pool method } \\ \text { RL } & \text { Legal Reserve Area } \\ \text { SCS-CN } & \text { Soil Conservation Service Curve Number method } \\ \text { SNA } & \text { Social Network Analysis } \\ \text { SRTC } & \text { Sensitivity-based Radio Tuning Calibration } \\ \text { SUDS } & \text { Sustainable Urban Drainage Systems } \\ \text { SWMM } & \text { Storm Water Management Model } \\ \text { VBA } & \text { Visual Basic for Applications } \\ \text { WSUD } & \text { Water Sensitive Urban Drainage } \\ \text { WWHM } & \text { Western Washington Hydrology Model } \\ & \end{array}$




\section{TABLE OF CONTENTS}

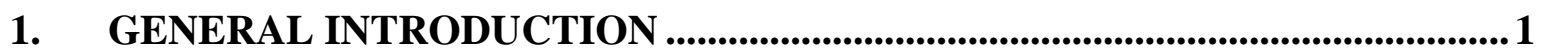

1.1 Research Hypotheses ..................................................................................................4

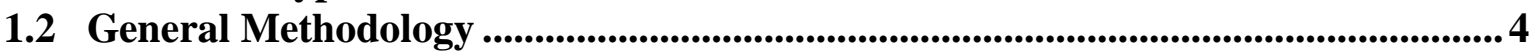

1.3 Relationship between Objectives, Methods and Products ........................................... 6

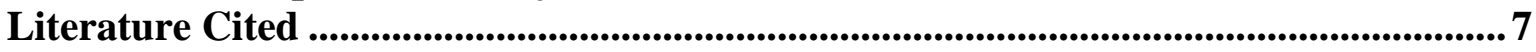

2. SUSTAINABLE URBAN DRAINAGE: DELINEATION OF A SCIENTIFIC

DOMAIN OF KNOWLEDGE PRODUCTION* .................................................................8

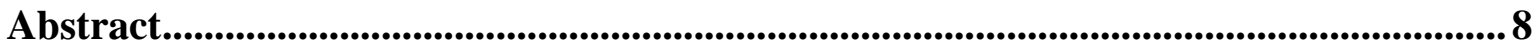

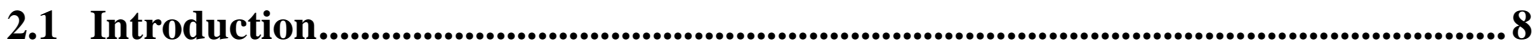

2.1.1 Theoretical perspectives on urban drainage ......................................................... 9

2.1.2 Methodological approach to the comprehension of the theoretical field of urban

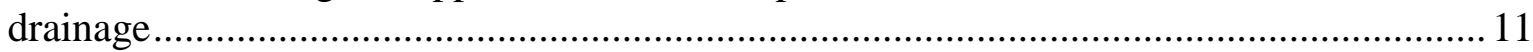

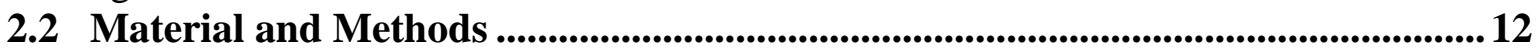

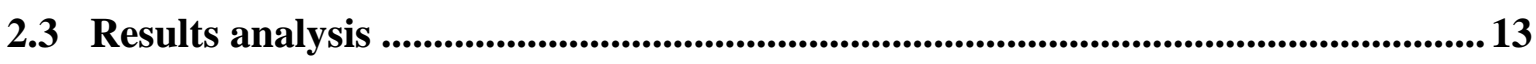

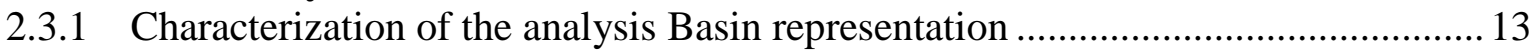

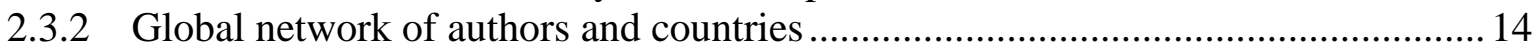

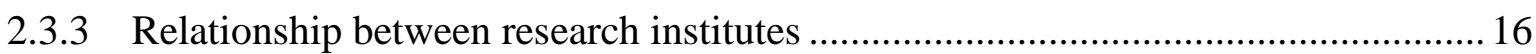

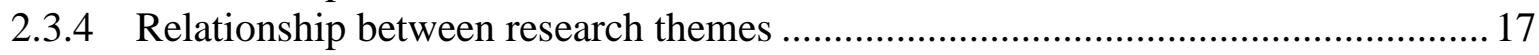

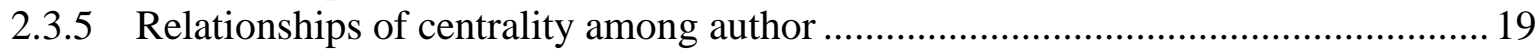

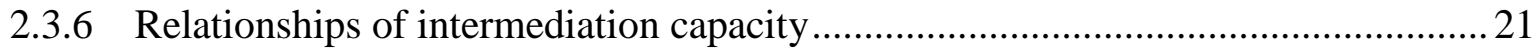

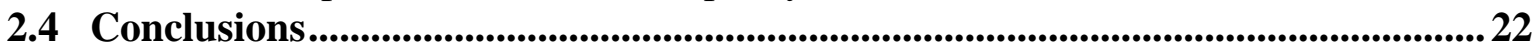

Acknowledgements ......................................................................................................................................2 24

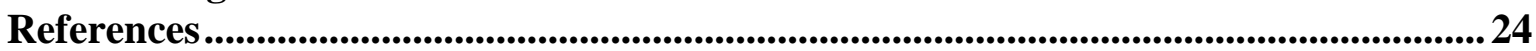

3. MODULAR SIZING FOR BIORETENTION SYSTEMS TO URBAN

SCENARIOS CONSIDERING TIME SCALE AND INCREASING URBANIZATION - A CASE STUDY IN THE CITY OF SÃO CARLOS, BRAZIL*27

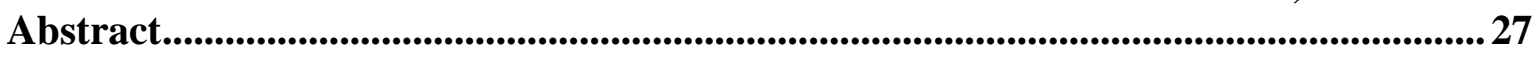

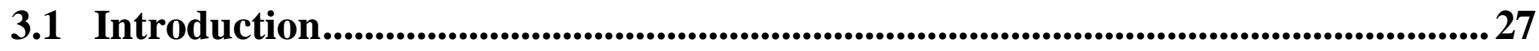

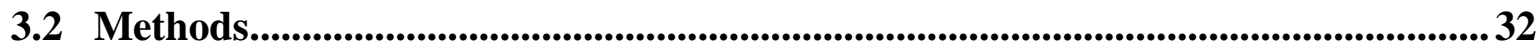

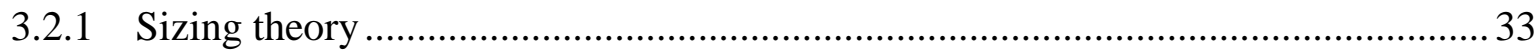

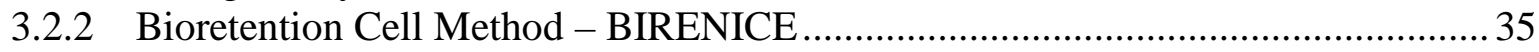

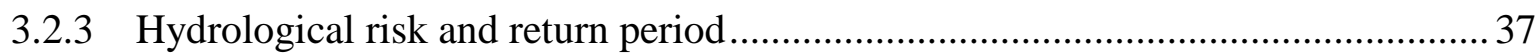

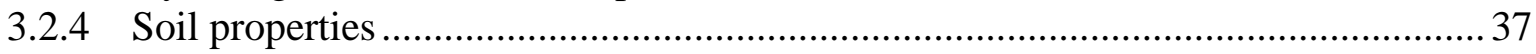

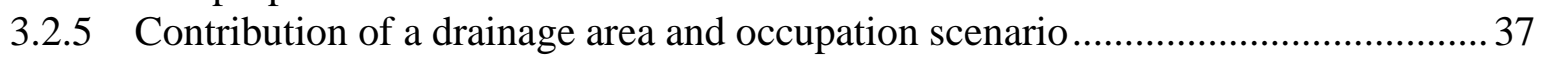

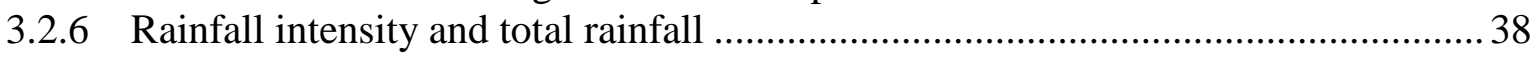

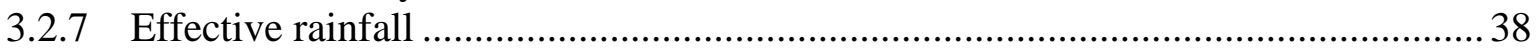

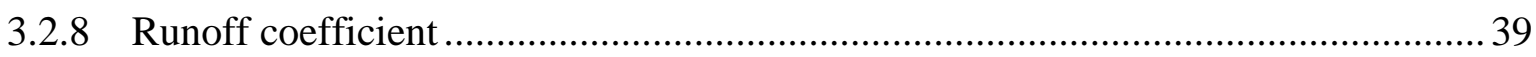

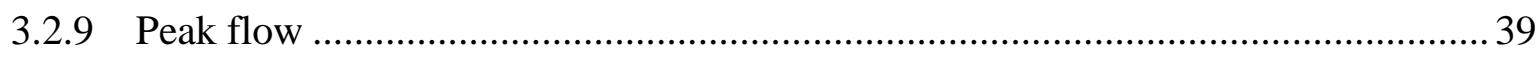

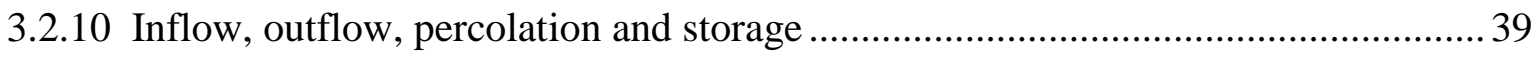

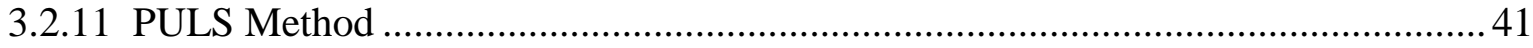

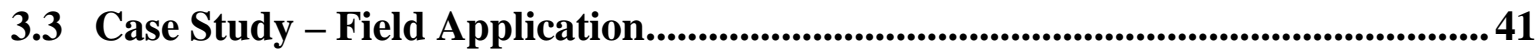

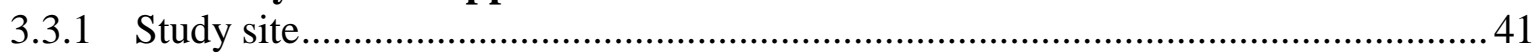

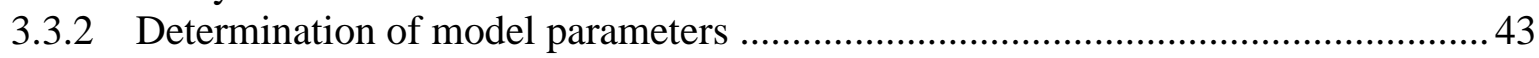

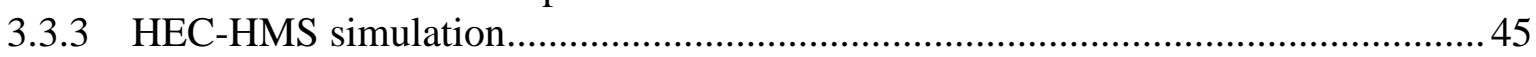

3.4 Results and Discussion......................................................................................45

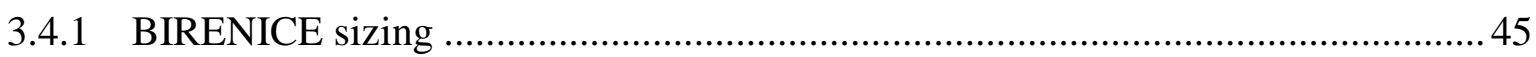

3.4.2 BIRENICE AND HEC-HMS simulations .................................................. 48 
3.4.3 Comparison between to the sizing methods described .......................................50

3.5 Conclusion ........................................................................................................................5 52

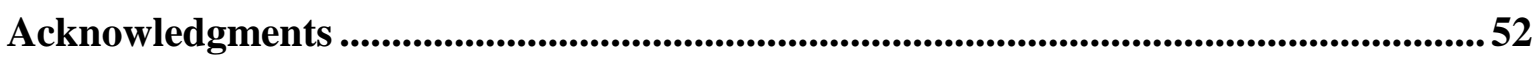

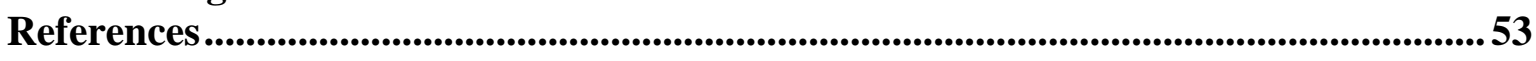

APPENDIX A - Calculation memorial ........................................................................55

APPENDIX B -Photographic memorial ...........................................................................559

APPENDIX C - Illustrative scheme of parameters of sizing equations .............................60

4. BIORETENTION AS A CONTROL TO URBAN DRAINAGE SYSTEM

WITH AN ECOHYDROLOGICAL BASE: GIS AS A TOOL ON DECISION

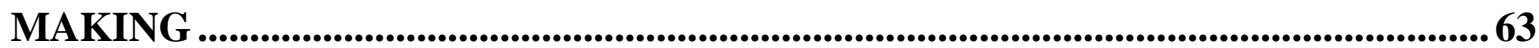

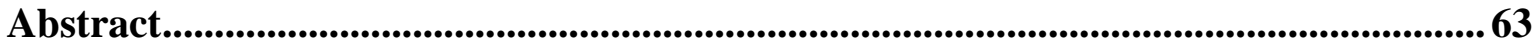

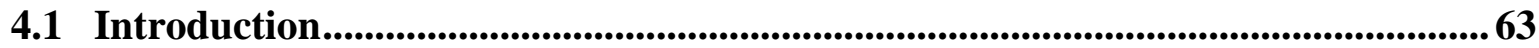

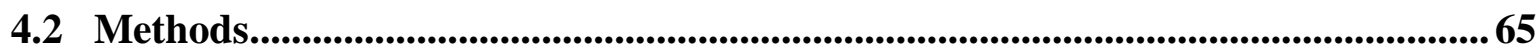

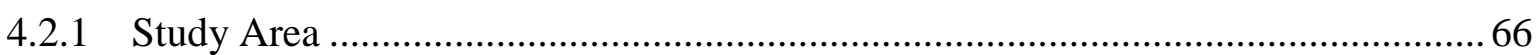

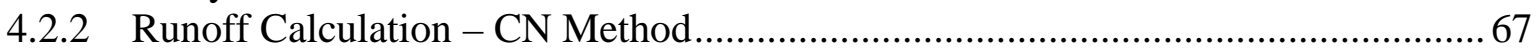

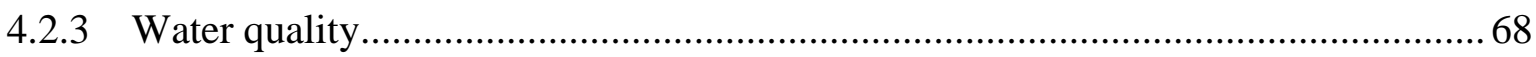

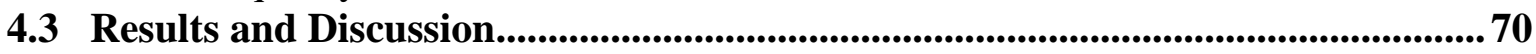

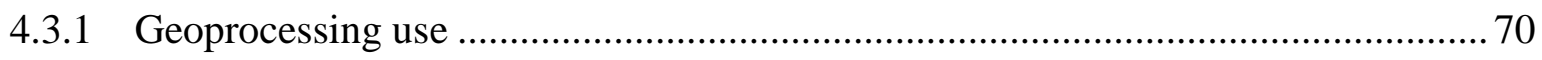

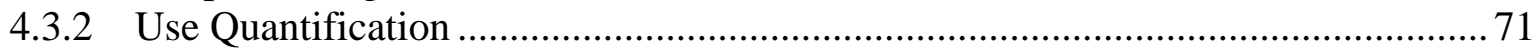

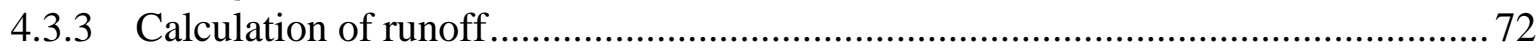

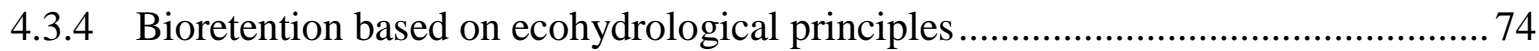

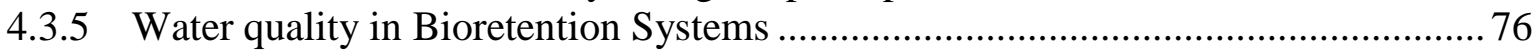

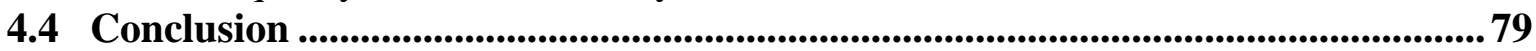

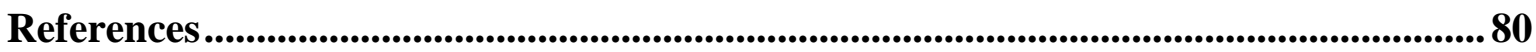

5. USING PCSWMM TO EVALUATE THE EFFICIENCY OF A BRAZILIAN

MODULAR BIORETENTION DESIGN FOR STORMWATER TREATMENT..... 83

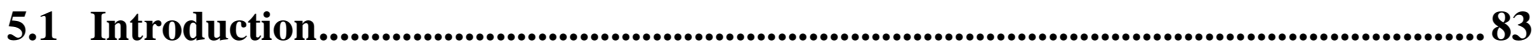

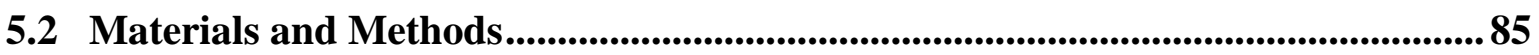

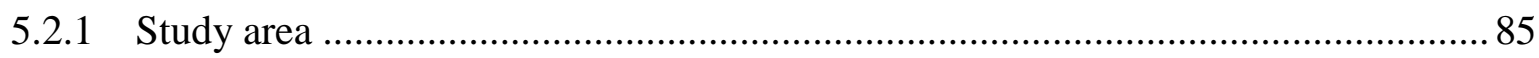

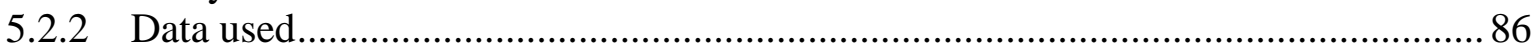

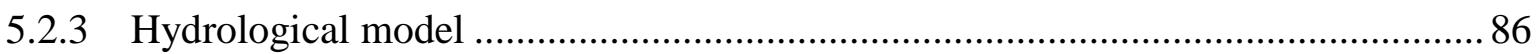

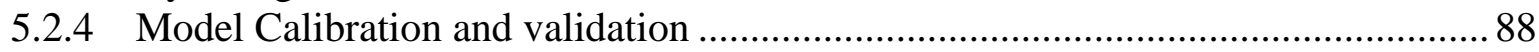

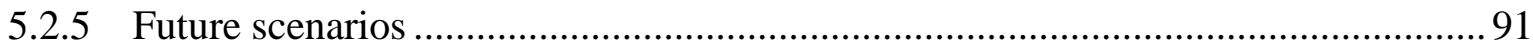

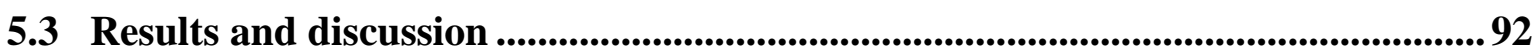

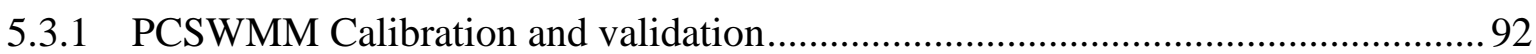

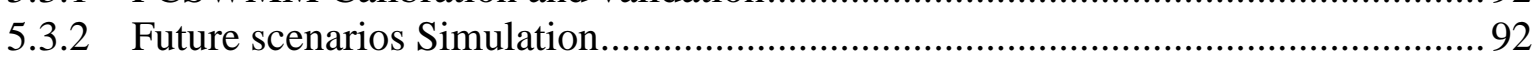

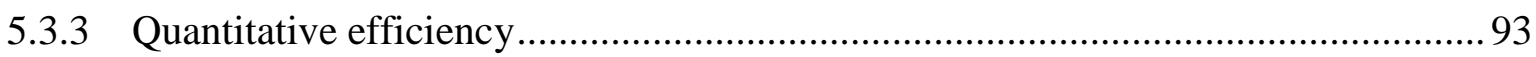

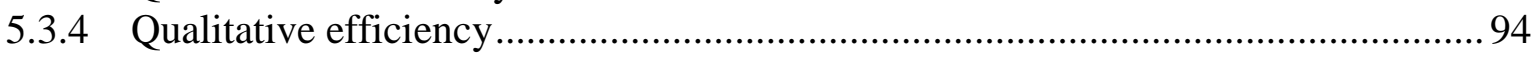

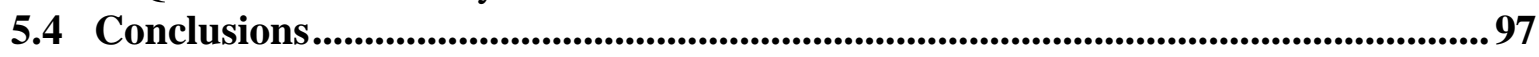

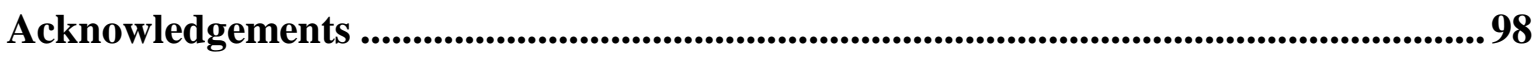

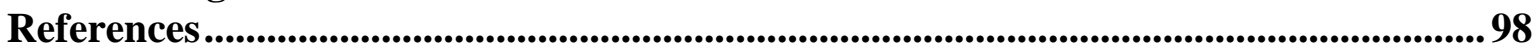

APPENDIX A - Plotted graphs for washoff IN ............................................................................. 103

APPENDIX B - Plotted graphs for washoff OUT .......................................................... 104

APPENDIX C - Table of parameters values were used for the calibration ....................... 105

6. GENERAL CONCLUSION ............................................................................... 106 



\section{GENERAL INTRODUCTION}

Historically, urban drainage in Brazil has focused on surface runoff water treatment, resulting in the concept of conduit based drainage systems, as highlighted by Pompêo (2000). In the 1990s, the Brazilian research centers that worked with urban drainage sought to adapt the so-called "Compensatory Techniques" (CTs) to compensate the effects of urbanization for the runoff, whose review and typology are discussed by Baptista et al. (2005). These CTs were adaptations of techniques developed by research groups from Europe, the U.S. and Australia. Currently, these concepts have brought out considerations and changes in the paradigms of the new Urban Master Plans (PENNINO et al., 2016). These experimental and adaptive approaches have been named as Sustainable Urban Drainage Systems-SUDS, Water Sensitive Urban Design -WSUD, Best Management Practices-BMP and/or Low Impact Development-LID (SAMPLE et al., 2014; HUNT et al., 2006).

According to A. Morales-Torres et al. (2016), urban stormwater management is a complex subject, directly linked with other parts of the urban water cycle: the management of one element (either good or bad) can influence the successful management of another one. Considering this, this thesis is divided in several chapters to explore this complexity. Thus, it is presented in the first chapter of this thesis the general introduction of this work, its objectives and research hypotheses, as well as, the description of the general methodology for the thesis construction and a list of goals with its respective chapters.

It is observed that these new concepts essentially address the same principles and the same types of solutions, whether by structural and/or non-structural means. According to Fletcher et al. (2012), these new approaches prioritize induced infiltration, retention, runoff bio-filtration, control at the runoff source, landscape integration with the urban space, non-transfering of the downstream impacts and a multidisciplinary approach to environmental education and social participation. In this sense, the second chapter demonstrates, through bibliometric technique, a survey of publications and research projects, from a collection of 22 terms frequently used in the subject sustainable drainage.

In short, all concepts are related to maintaining the urban conditions as close as possible to the natural conditions of the hydrological cycle (qualitative and quantitative), seeking to integrate quantity efficiencies (stored volumes, attenuated peak flows, delay of flow time) and water quality (considering diffuse pollution with the physical-chemical, microbiological and ecotoxicological aspects). 
However, in spite of two decades of developing CTs in Brazil, there has been little practical usage of the solutions developed, especially at the scale where they have been studied. The main reasons are driven by the scale of drainage problems: I) there is a preference for detention reservoirs in macro drainage systems (CANHOLI, 2005), due to a lack of technical upgrading of the drainage management agencies to deal with the implementation, operation and maintenance of diffuse, decentralized and small structures,; II) society has difficulty in understanding the relationship between small-scale solutions and large-scale problems: experimental research has focused on control at the source on a local scale, while the urban drainage problems are seen on a large scale, as well as the difficulty of inserting qualitative and quantitative parameters in the design of bioretention systems.

Thus, the third chapter details the methodology used to measure and simulate the bioretention system, object of this research, entitled BIoREteNtIon CEll method BIRENICE. And it also compares it with the HEC-HMS model, which is widely used in researches.

One of the main difficulties in choosing propitious areas to build bioretention systems ends up being the characterization and detail of the terrain. Some factors such as slope, land use and soil type must be taken into consideration. Regarding this difficulty, the fourth chapter demonstrates, with the use of GIS tools along with some indicators from ecohydrological studies, a more detailed and precise analysis of suitable areas for building bioretention techniques. Emphasizing that the system of monitoring has shown that the benefits of CT implementation constitute a landmark for urban drainage.

The fifth and final chapter evaluate the performance of bioretention technique through computer simulations as a result of mathematical modelling through the SWMM5 PCSWMM in version 6.2. The model inputs correspond to hydraulic, hydrometeorological and geotechnical components, being calibrated by the method of multiobjective optimization, allowing users to set tolerances for the parameter of uncertainty in SWMM layers, running the model to the extremes of this range of uncertainty. The model responds in the form of the flow and level of water infiltration, making it possible to evaluate the removal of pollutants and the water volume for different characteristics of precipitation events.

This doctorate research project is connected to and has the financial support of three ongoing projects: (1) MAPLU2 - Stormwater Management in the Urban Environment/FINEP Agreement 0982/10(01.10.0701.00), composed of a network of 16 
Brazilian IES, (2) Thematic Project FAPESP 2008/58161-1 “Assessment of Impacts and Vulnerability to Climate Change in Brazil and Strategies for Adaptation Options", through its Component 6 (EESC/USP) "Mitigation and adaptation measures of vulnerable communities to cope with water-related risks derived from climate change scenarios at river basins of São Carlos"; and (3) Casadinho/PROCAD CNPq 552494/2011-9 (UFALEESC/USP) “Advanced monitoring of biotechnological processes and environmental quality".

This research has an integrative aspect of the three (presented) projects, through which it was possible to reach the objectives proposed here. With MAPLU2 project, a broad network of researches and partnerships was accessed, fortifying the following study through experiments, replicating methodologies and Compensatory Techniques experiments in different regions of Brazil.

With the thematic project, FAPESP research was inserted in the subject of climate changes and its consequences to the urban environment, reflecting the contributions of this study for this research field, strengthening the proposal to model future scenarios due to the impacts caused by urbanization.

While participating in the Casadinho/PROCAD project, it was possible to deepen the knowledge obtained related to water monitoring quality. As follows, one of the main objectives of this project, which intended to study the application of molecular techniques to detect pathogenical organisms in the environment, especially in urban scenarios, is to contribute to the water resources management through compensatory monitoring techniques, mainly of urban areas.

It is important to notice that the participation in these projects provided great visibility to the research by participating in major international scientific events. One of the events was the Scientific Expedition Brazil - Germany, 490148/2011 - 5o Planning tools and measures for sustainable management of water resources in Brazil. This expedition involved researchers from the University of Kassel and University of São Paulo (São Carlos School of Engineering - EESC). Another important event was the International conference on Water, Megacities and global change - 2015 December 1st - 4th 2015 at UNESCO HQ - Paris - France. After this participation, the project gained visibility in Brazil, published in printed and televised media. 


\subsection{Research Hypotheses}

Considering the state of the art on CTs for the control of diffuse pollution of urban drainage, these research hypotheses state that:

- The compensatory techniques, when studied in the form of combined detention with bioretention, represent more efficient adaptation strategies to control urban drainage changes in the long run,

- Under these scenarios, the master plans seek to optimize resources and incorporate drainage resilience, therefore the techniques will actually be compensatory if progressive systematic rehabilitation or "modular" steps are included to increase efficiency during its lifetime,

- Ecohydrological indicators are tools that evaluate how this generalized efficiency is increased, and how quantity and quality of diffuse pollution could better characterize urban drainage if an experimental and adaptive approach is used.

\subsection{General Methodology}

The general methodology follows the schematic flow chart shown in Figure 2.1, divided into six steps: (1) pollutant loads analysis enchases the diffuse pollution of urban drainage; (2) theoretical-adaptive approach of the compensatory techniques (CT) practices is used; (3) experimental approach with sizing by detention and bioretention; (4) choosing of experimental areas for construction of compensatory techniques practices; (5) installation and quality-quantitative monitoring during the working of compensatory techniques practices; and (6) performance evaluation of CT. The discussed methodology may apply to any situation. 


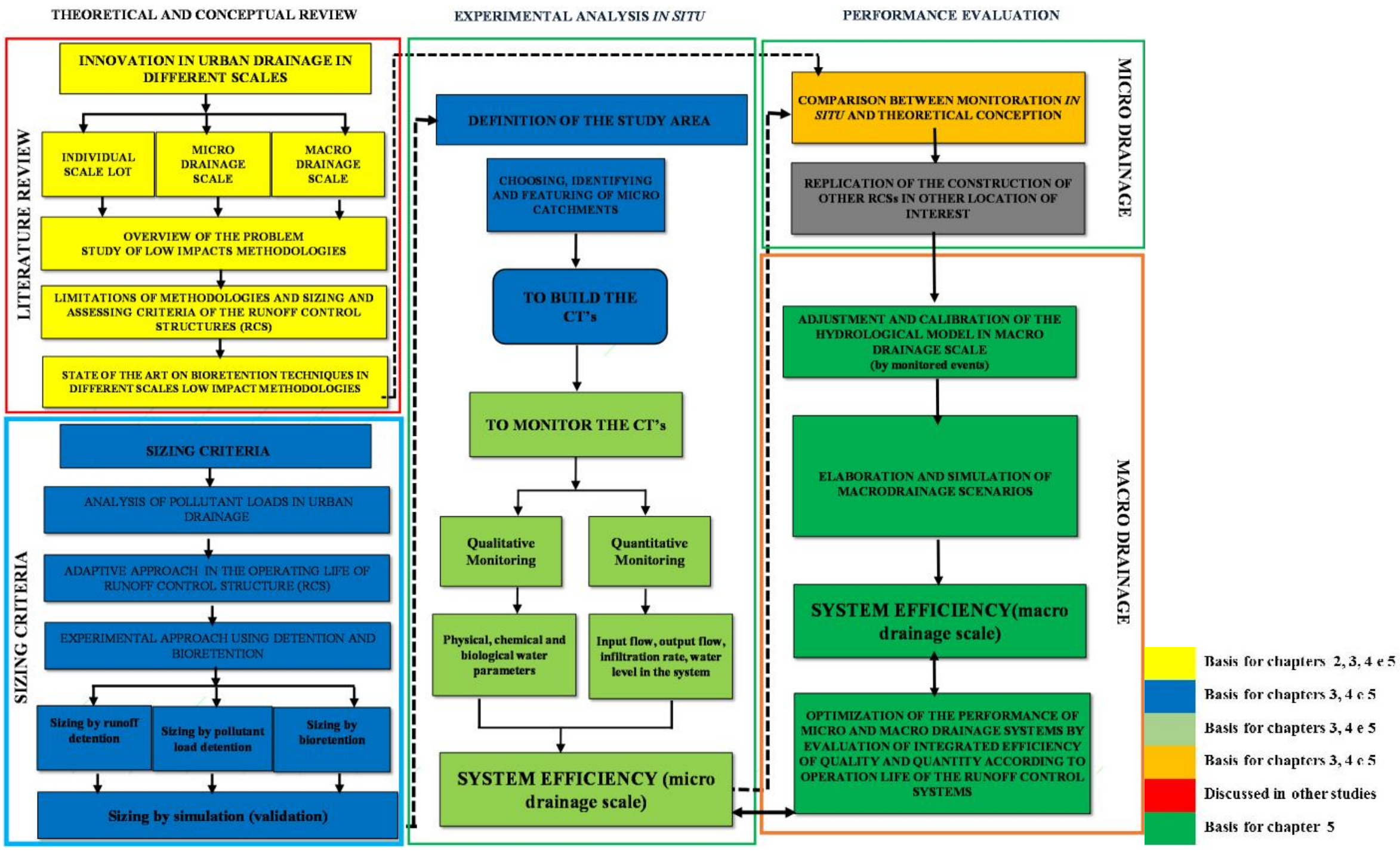

Figure 1.1 - Long-term project flowchart 


\subsection{Relationship between Objectives, Methods and Products}

Figure 1.2 shows the flowchart of the practical implementation of this research. The first phase was the construction of a CT system, based on a comprehensive study and characterization of the area to be implemented, taking into account the legal and administrative requirements of land use and ecohydrological indicators. The research recognizes that the use of compensatory techniques can be an effective alternative to stemmed diffuse pollution control of urban drainage, using experiments built in real scale in previously selected areas.

From documentary and literature surveys that culminated in the discussion of the methodological scope and its limitations and through a thorough theoretical overview, the methodology was developed. Bibliometric techniques were used and supported the understanding of different denominations related to sustainable urban drainage techniques as well as research groups, institutions and researchers involved. It resulted in the article:

Sustainable urban drainage: delineation of the scientific domain of knowledge production.

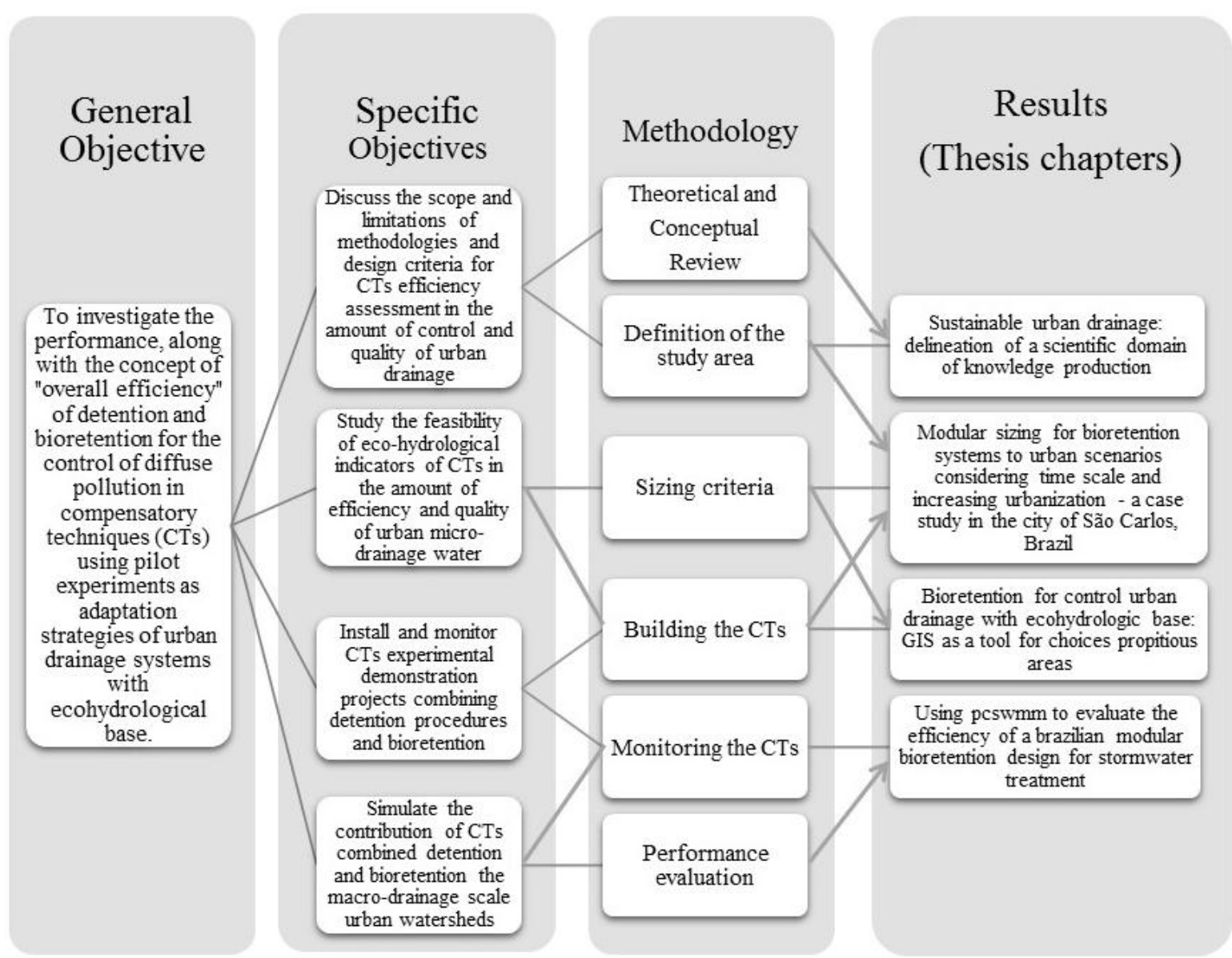

Figure 1.2 - Practical implementation flowchart 
Through the proposed and implemented sizing model, adding to the aggregate knowledge through conceptual theoretical research, it was proposed the second product, which deals with the methodology used in the design of CTs system, the object of this research. It demonstrates innovative aspects as modular design and considered qualitative and quantitative aspects. This step resulted in the article: Modular sizing is bioretention systems to urban scenarios considering scale and increasing urbanization time - a case study in the city of São Carlos.

The choice of areas to construct the CTs systems can be considered one of the most complicated steps in the implementation process and monitoring of these techniques. The project was implemented with the support from the Brazilian legal framework and ecohydrologicals indicators that supported the preliminary studies, giving rise to the fourth chapter of this thesis called: CT for control urban drainage with ecohydrology base: GIS as a tool for choices propitious areas.

The last paper, but not least, demonstrates that through the use of PCSWMM for modelling qualitative and quantitative data obtained by monitoring the compensatory technique, it is possible to study CT's performance.

Thus, the project included the methodological steps ranging from the study of the relevance of compensatory techniques in urban drainage to computer simulations to evaluate the performance of the project after its construction.

\section{LITERATURE CITED}

BARBOSA, A. E.; FERNANDES, J. N.; DAVID, L. M. Key issues for sustainable urban stormwater management. Water research, v. 46, n. 20, p. 6787-6798, 2012.

CANHOLI, A. P. Urban Drainage and Flood Control. Oficina de Textos Publisher, São Paulo, Brazil (in Portuguese), 2005.

HUNT, W.F., JARRETT, A.R., SMITH, J.T., SHARKEY, L.J., 2006. Evaluating bioretention hydrology and nutrient removal at three field sites in North Carolina. J. Irrig. Drain. Eng. ASCE 132, 600-608.

POMPÊO, C. A. (2000). Sustainable Urban Drainage. Brazilian Journal of Water Resources. Rio Grande do Sul.

SAMPLE, D., RANGARAJAN, S., BOONE, M., LEE, J., AND MANGUEURRE, H., 2014. Urban wet-weather flows, Water Environ. Res.

WALSH, Christopher J.; FLETCHER, Tim D.; BURNS, Matthew J. Urban stormwater runoff: a new class of environmental flow problem. PLoS One, v. 7, n. 9, p. e45814, 2012. 


\title{
2. SUSTAINABLE URBAN DRAINAGE: DELINEATION OF A SCIENTIFIC DOMAIN OF KNOWLEDGE PRODUCTION*
}

*A modified version of this chapter has been submitted as: ROSA, A.; PROCOPIUCK, P.; MACEDO, M. B.; SAMPLE, D.; SOUZA, V. C. B.; MENDIONDO, E. M. Sustainable urban drainage: delineation of a scientific domain of knowledge production. Submitted to Water Resources Management. Manuscript Number - WARMD-16-00952.

\begin{abstract}
Sustainable Urban Drainage emerged and gained prominence during the late 90s. Despite this progress, there is little uniformity in subjects and definition of terms within the overall sustainability theme. This tends to create a duplication of objectives and confusion about the correct use of techniques and procedures. This paper seeks to identify, map and evaluate 'Sustainable Urban Drainage' as a scientific domain, using relationships between underlying subthemes. We analyzed 3,805 publications by 8,237 authors with relation to 11,957 citations using sociometric and bibliometric techniques. The results confirm the existence of the knowledge domain with one main nucleus and 20 independent networks. Core subthemes such as stormwater management, low impact development, integrated urban water management, bioretention, and best management practices are distinguishable the main domain.
\end{abstract}

Keywords: scientific domains, low impact development, integrated urban water management, bioretention, best management practices

\subsection{Introduction}

Questions related to urban drainage have occupied professionals and researchers in different contexts. Over the last decades, practical results, adaptations, experiences and techniques have been the object of scientific literature originating mainly from Europe, the United States of America (USA), and Australia. Research within the area of natural hydrological cycles represents a point of convergence within this theme.

A central concept in the urban drainage literature is knowledge generated in networks involving intellectual, social, and physical, chemical, and biological processes. Studies focusing upon the theoretical development and practical application of new methods are principally concerned with reducing negative impacts from urban development, as well as the expansion of the respect for the natural environment limitations.

From this perspective, studies of urban drainage range from those that are strictly technical in nature - e.g. induced infiltration, retention and (bio) filtration - to multidisciplinary socio-technical studies whose aim is to avoid downstream transfer of impacts, and reinforce environmental education and social participation. In this range of approaches ranging from the technical scope to the political one, the increasing concern on 
understanding how to operationalize socio-technical solutions capable of assuring significant levels of success based on the sustainable development principles become more relevant.

This paper seeks to identify, relate and analyse a group of research areas united by a sustainable urban drainage theme. This study maps and explains the relationships between authors and subthemes related to urban drainage in an international context. The work seeks answers to the following questions: Which are the main subthemes that emerge under the sustainable urban drainage theme? Which are the major countries and authors that stablish relationships among the subthemes? Which are the more active subthemes in the scientific community?

\subsubsection{Theoretical perspectives on urban drainage}

As communities build improved responses to urban drainage problems, social research that explains how scientists interact and how they reach consensus on methods is conducted. Scientific enterprise depends, to a large extent, on the community's ability, to adopt assumptions and dedicate themselves to implementing specific practices, until new scientific knowledge becomes available. New investigations will consequently lead the community to a new set of practices. While it is theoretically possible to repeat this process indefinitely, in reality it tends to degrade over time, eventually leading to the emergence of new methods, which, as they propagate, repeats the process. Within the sustainable urban drainage theme, the fundamental questions currently in discussion pertain mainly to general methods and philosophical principles (KUHN, 2000, pp. 23-25).

In the case of conventional urban drainage systems, efforts to expand knowledge tends to concentrate on internal components (GELDOF, 1995). For example, reducing runoff volume through infiltration, removes this source of flow to downstream areas more or less permanent. This influence is perceived on the amount of technical developments and theoretical framework about drainage based on conduits for the construction of stormwater sewers and actions to increase the flow capacity of rivers and canals (POMPÊO, 2000; PROCOPIUCK \& ROSA, 2015). Although, this perspective on development of knowledge about urban drainage is important in the scope of technological development as well as fast responses to emergency problems; it showed itself little fruitful in offering more aligned solutions to the sustainable development.

Since the 60s, municipal master plans have adopted protection of natural resources as a policy goal, indicating a broader focus of urban drainage. Research are now focused on 
aspects other than flooding of streams to overcome problems caused by the development of integrated methods and measures to mitigate urbanization effects (GELDOF, 1995, p. 16; POMPÊO, 2000).

The development of techniques to reduce flows by temporary storage in the soil, through infiltration was created out of necessity to prioritize planning actions (POMPÊO, 2000). While originating in the broad strategies of environmental management, urban drainage can be understood as a network of relationships between intellectual, social, physical, chemical, and biological processes (GELDOF, 2005).

On a constant development process marked by new demands of sustainable urban development, the technicist paradigm was replaced by a new perspective focused on multifunctional adaptive structure for managing natural resources. Integrated management emerges as a multidisciplinary approach to face uncertainties on how to handle natural resources (JEFFREY \& GEAREY, 2006). This change of perspective has contributed significantly to the rise of a new concept of urban drainage, sustainable urban drainage (SUD).

SUD research can be classified into: alternative techniques (Tim D. Fletcher et al., 2014), best management practices (Davis, Hunt, Traver, \& Clar, 2009; Tim D. Fletcher et al., 2014; Zhou, 2014;), bioretention systems (R. A. Brown \& Hunt III, 2010; Davis, 2008; Lucas \& Sample, 2015; Sample et al., 2012; Sample \& Liu, 2014), compensatory techniques (Tim D. Fletcher et al., 2014), design stormwater (Park, Chung, Yoo, \& Kim, 2012), diffuse pollution control (Panagopoulos, Makropoulos, \& Mimikou, 2013), green infrastructure (Tim D. Fletcher et al., 2014), integrated urban water management (Tim D. Fletcher et al., 2014), low impact development (Tim D. Fletcher et al., 2014; T. J. Scott et al., 2014; Zhou, 2014), low impact urban design and development (Tim D. Fletcher et al., 2014; Zhou, 2014), management of urban drainage (Tim D. Fletcher et al., 2014), management of urban water (R. Brown, 2005; Lee \& Yigitcanlar, 2010), source control (Tim D. Fletcher et al., 2014), stormwater control measures (Tim D. Fletcher et al., 2014), stormwater management (Davis et al., 2009; Roseen et al., 2009; T. J. Scott et al., 2014; Zakaria, Ab Ghani, Abdullah, Mohd. Sidek, \& Ainan, 2003), stormwater quality improvement devices (Begum, Rasul, \& Brown, 2008), stormwater quality studies (T. D. Fletcher, Andrieu, \& Hamel, 2013; Newman, Aitken, \& Antizar-Ladislao, 2013; Zakaria et al., 2003), stormwater quantity studies (R. Brown, 2005; Zakaria et al., 2003), stormwater treatment efficiency (Zhang, Zhou, Li, \& Yu, 2010), sustainable drainage systems (Lee \& Yigitcanlar, 2010), sustainable urban drainage systems (Tim D. Fletcher et al., 2014; Zhou, 2014), and water Sensitive Urban Design (Davis et al., 
2009; Tim D. Fletcher et al., 2014; Lee \& Yigitcanlar, 2010; Sharma, Gray, Diaper, Liston, \& Howe, 2008).

The increase and spread of different approaches to understand a phenomenon tends to demonstrate its importance and dynamic. However, in this case, it complicates effectively understanding the domain and its central themes. In this study, we investigate the direction of SUD research.

\subsubsection{Methodological approach to the comprehension of the theoretical field of urban} drainage

Considering this complexity, we contend that clarity and direction of the research themes within SUD can be enhanced through domain analysis. According to Argas-Quesada and de Moya-Anegón (2007), domain analysis is one of the novel fronts of research emerging from advancements in information visualization of networks and this approach helps reveal the essence of scientific knowledge, especially in multidisciplinary fields with intense changes.

Domain analysis is based upon the concept that the best way to comprehend a knowledge field is through analysis of speech patterns, and identifying the networks that provide structure to knowledge areas. Knowledge domains contain unique structures and organization, and standards of cooperation, language, and communication means (ArgasQuesada \& de Moya-Anegón, 2007; Hjørland \& Albrechtsen, 1995). Based on sociometric criteria, domain mapping generates images that express the networks, relationships, and roles that scientific communities play in society (Argas-Quesada \& de Moya-Anegón, 2007; Hood \& Wilson, 2000).

In addition, bibliometric analysis reduces subjectivity by informing statistics such as the number of authors, of publications, and of countries of origin in the citations of a domain category (Price, 1976, p. 39). Bibliometric studies use statistical and mathematical methods to identify historical trends in the literature and assess emerging standards, mainly through analysis of the relationship between authors and the use of domain knowledge and themes. In these studies, a sociometric technique known as the Social Network Analysis (SNA) perspective is often used. SNA views the researcher as a socially interconnected actor. Advancing science and producing knowledge requires interactions, associations and the union of abilities according to common views. This is especially the case with collaborative works. 
The central-periphery model provides an important tool for SNA, facilitating the evaluation of cohesion between nodes in a network. This evaluation algorithm calculates the proximity values in relation to the center and, from that, the correlation between the empirical matrix and the theoretical one. The evaluation was conducted with continuous method to attribute a score to the relationships of each node to the center (Borgatti \& Everett, 1999).

\subsection{Material and Methods}

The bibliometric analysis was conducted in two phases. First, was performed under a qualitative method through the choice of expressions from a body of text comprised of 50 papers that address different perspectives of SUD studies; the papers served as a basis to the construction of a research project under the theme. The objective was to make a systematic survey of the most relevant terms and expressions. That survey resulted in 22 expressions, which are listed in Table 2.1

Second, phase was conducted using a quantitative method, exploring research papers and reviews that contained high information credibility and authored by prominent researchers in the SUD field. The data was compiled in August 2015, from the Web of Science database, covering all complete papers and reviews registered since the year 1864. The software VantagePoint (Search Technology, 2006) was used to house and structure the data and assist in further analysis.

Initially, 18,662 documents were identified, which reduced to 3,805 , in the second phase. A filter was used in the following areas: Environmental Science Ecology, Engineering, Water Resources, Agriculture, Geography, Architecture, Science technology other topics, Urban Studies, Biodiversity Conservation, Physical Geography, Chemistry and Public Administration. This refinement was necessary because many expressions have multiple meanings, outside the interest of SUD research.

The queries in the 'Web of Science' were based on the expressions in the first column of Table 2.1. The searches included each expression altogether in quotation marks. Thus, abbreviations and acronyms were omitted.

The data in the last column of Table 2.1 was condensed, for each expression, in a matrix of co-citation in the software VantagePoint. These databases were converted into edglist1 files through Visual Basic for Applications (VBA) codes run inside Microsoft Excel, to be imported by the software Ucinet. The visualization of the networks was made with the software NetDraw. 
Finally, the evaluation of the centrality of countries, institutions, themes and authors occurred using the Core/Periphery model of Ucinet (Borgatti, Everetti, \& Freeman, 2002), with 1,000 interactions processed based on continuous method. Centrality was evaluated using the Gini index, where 0 stands for complete equality and 1 stands for complete inequality.

\subsection{Results analysis}

In the following topics, there is a first a characterization of the body of analysis comprised by the documents resulting from the search on Web of Science. Subsequently, it is presented the global result based on the centrality relationships between authors relative to locations. Then, the centrality and peripheral relationships of universities or research centers, to which the authors are affiliated were characterized, as well as the themes reviewed in this research; and finally, the relationship between authors without an institutional mediation.

\subsubsection{Characterization of the analysis Basin representation}

All documents selected by the search terms from the first phase, i.e., without any filter are contained in column (b) of Table 2.1 There are the number of documents in the research fields with affinity with the theme in column (c). Finally, the remaining documents used in body of analysis of this paper is provided in column (d).

\begin{tabular}{|c|c|c|c|}
\hline \multirow{2}{*}{ (a) Searched expression } & \multicolumn{3}{|c|}{ Number of publications resulted from the search } \\
\hline & (b) Found & (c) Refined & (d) Used \\
\hline 1) Alternative techniques & 2025 & 249 & 239 \\
\hline 2) Best management practices & 5388 & 1156 & 1122 \\
\hline 4) Compensatory techniques & 32 & 3 & 2 \\
\hline 5) Design stormwater & 5 & 4 & 4 \\
\hline 6) Diffuse pollution control & 31 & 26 & 24 \\
\hline 8) Integrated urban water management & 86 & 69 & 66 \\
\hline 9) Low impact development & 349 & 249 & 215 \\
\hline 10) Low impact urban design and development & 6 & 4 & 3 \\
\hline 11) Management of Urban Drainage & 12 & 11 & 11 \\
\hline 12) Management of Urban Water & 51 & 28 & 26 \\
\hline 13) Source control & 8107 & 319 & 298 \\
\hline 17) Stormwater quality & 298 & 210 & 207 \\
\hline 18) Stormwater quantity & 34 & 27 & 25 \\
\hline 19) Stormwater treatment efficiency & 5 & 5 & 5 \\
\hline 20) Sustainable drainage systems & 64 & 59 & 59 \\
\hline 21) Sustainable urban drainage systems & 65 & 57 & 57 \\
\hline 22) Water Sensitive Urban Design & 106 & 82 & 82 \\
\hline TOTAL & 18.662 & 3979 & 3805 \\
\hline
\end{tabular}

Table 2.1 - Expressions searched in the Web of Science base 
There are disparities among the results in Table 2.1 regarding the number of documents found, refined and used for each searched term. That happens because some terms are considered as techniques or a set of techniques in a global scope - for example, Alternative techniques, Best management practices, Source control and Stormwater management - and others can be applied in different knowledge fields.

\subsubsection{Global network of authors and countries}

The global network showed in Figure 2.1 express the relational logic of the community studying SUD. This community is comprised of 8,237 authors from 82 countries. The authors relate to each other through 11,957 bonds stablished by their location.

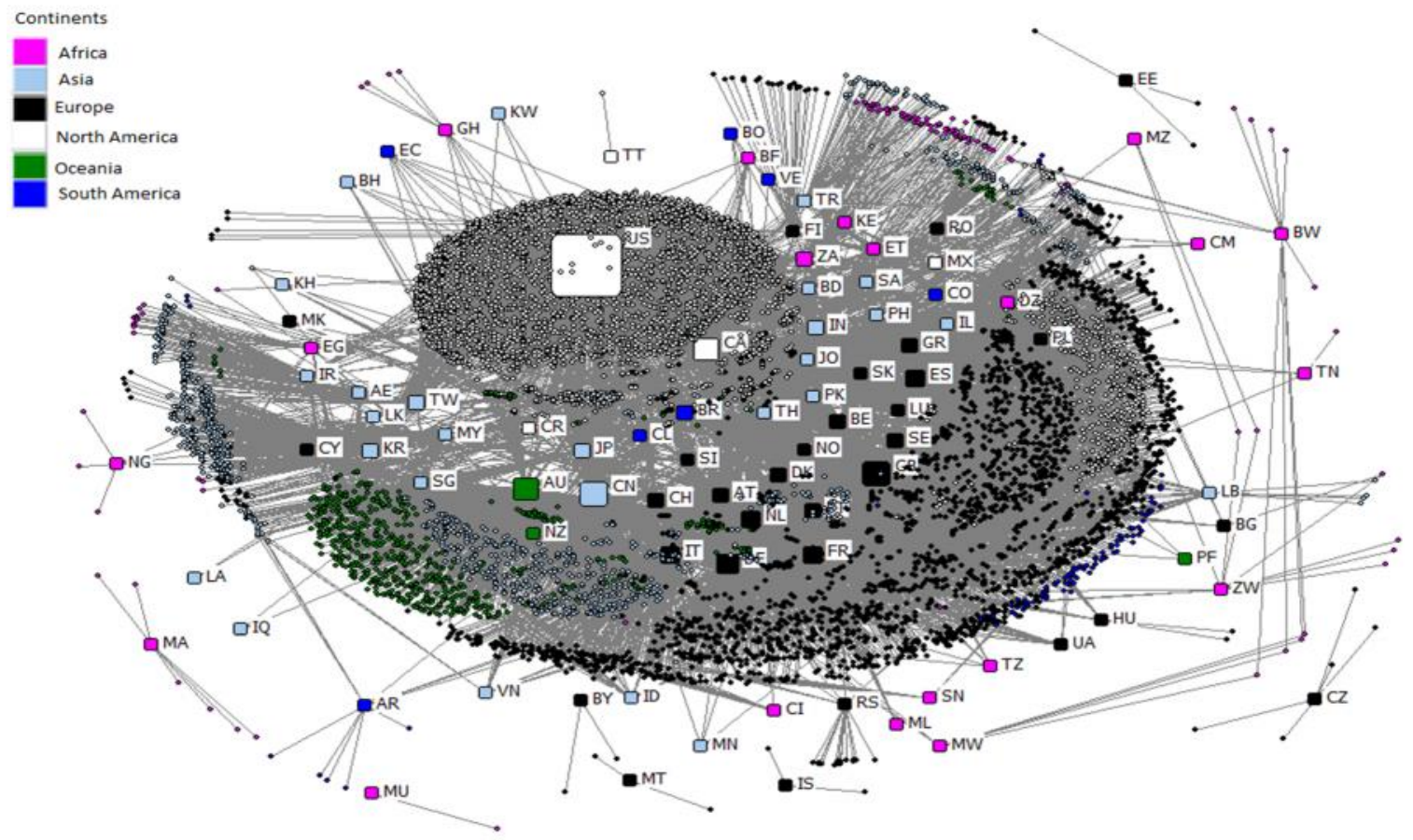

Figure 2.1 - Global network

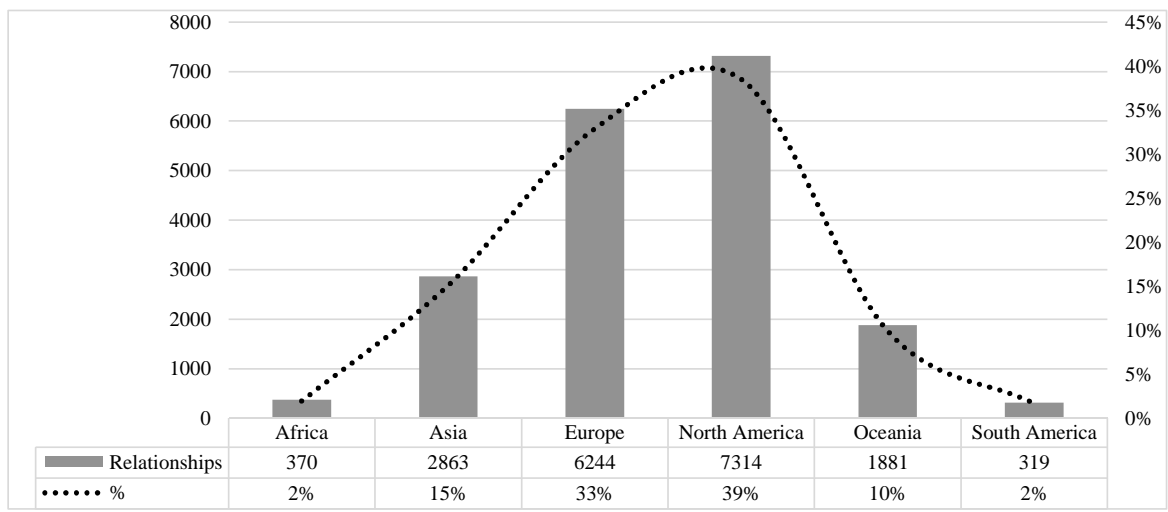

Figure 2.2 - Relationships between authors and countries related to continent 


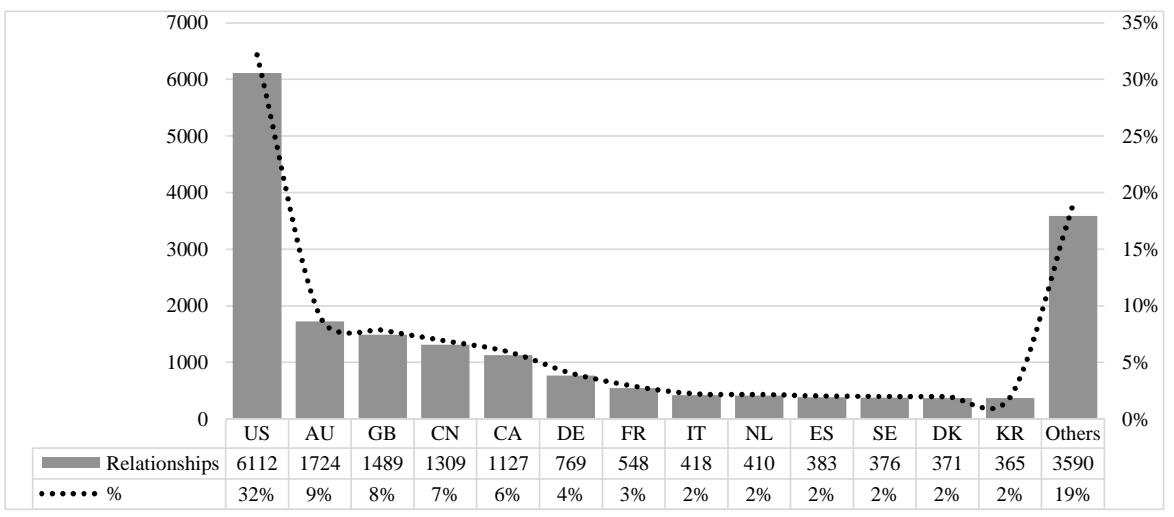

Figure 2.3 - Relationships between authors and countries related to countries

In the global network, $32 \%$ of authors are from the USA. An intermediary group formed by 12 countries sums up 49\% of authors. Finally, a last group of 80 countries gathers $19 \%$ of the authors. This distribution is verified in detail in the Figure 2.2. When author locations are consolidated from country to continent, it is apparent that $72 \%$ comes from North America and Europe, 25\% from Asia and Oceania, and 4\% from South America or Africa Figure 2.3. When internal and external relationships of the authors are considered, the central countries in the SUD research network are the USA, Australia, Canada, England, and Germany, as marked by a dashed line in Figure 2.4.

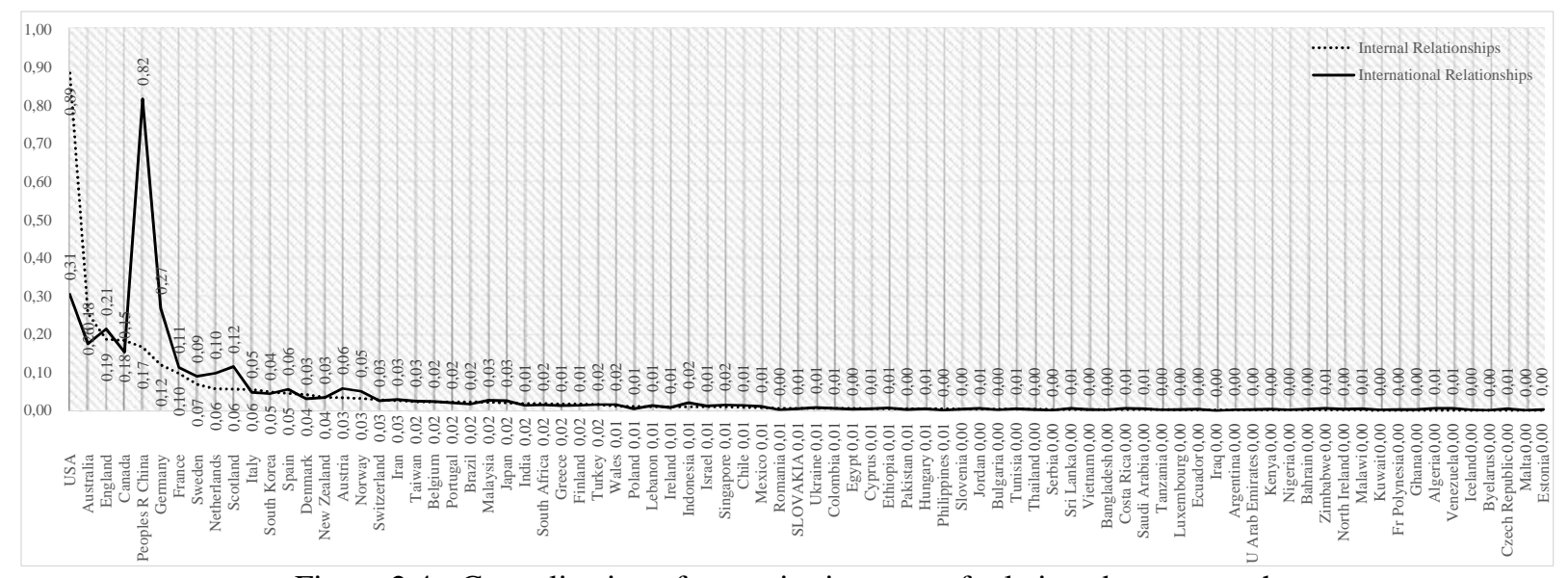

Figure 2.4 - Centralization of countries in terms of relations between authors

In Figure 2.4, the solid line represents the centrality of authors exclusive of their external relationships, i.e., international relationships. In this perspective, there is a shift of the order of the countries in terms of centrality. In order of importance, the sequence becomes the Peoples Republic of China (PRC), USA, Germany, England, Australia, and Canada. The centrality index considering internal and external relationships are 0.786 , considering only international relationships, the centrality index is 0.770 . 


\subsubsection{Relationship between research institutes}

Regarding the relation between centrality and peripheral of institutions to which the authors are affiliated, in the universe of 2,027, 12 are from the USA, 3 from Australia, 2 from China, 1 from Sweden, 1 from Austria and 1 from Denmark. In Figure 2.5, the first 14 institutions were classified as central by the central-periphery model. From North Caroline State University onwards, the following 2,020 institutions are considered peripheral.

With the application of the core-periphery model considering the internal relationships of the authors from the institutions, the correlation coefficient was 0.197 and the Gini index, 0.909. The model 'reclassified as core members the first 14, with a concentration correlation coefficient of 0.879 . When only external relationships were considered, the correlation coefficient was 0.236 . The Gini index was the same, as well as the number of core authors. In both evaluations there was no alteration in the centrality indices of the institutions. The 20 most central institutions are shown in Figure 2.5.

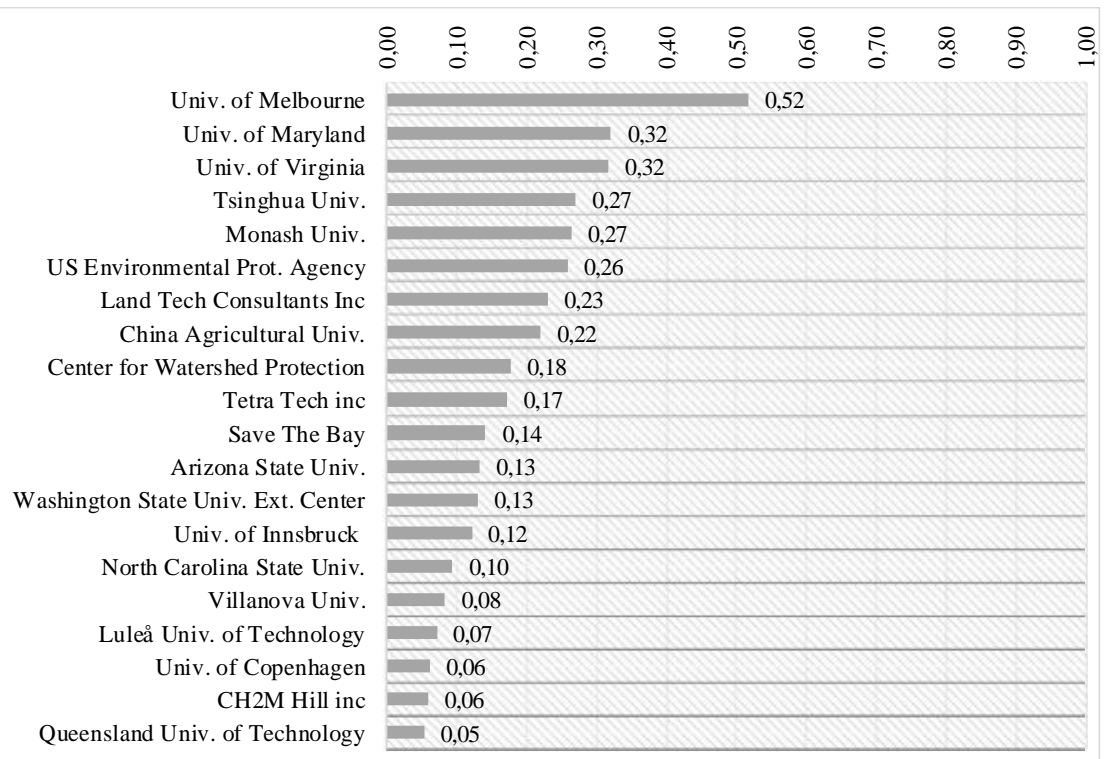

Figure 2.5 - Institutions centrality

The Australian universities took the $1^{\text {st }}$ position (Melbourne), $5^{\text {th }}$ (Monash) and $20^{\text {th }}$ (Queensland). In this list, in quantitative terms, prevail the universities and institutes from USA as $2^{\text {nd }}$ position (Univ. of Maryland), $3^{\text {rd }}$ (Univ. of Virginia), $6^{\text {th }}$ (U.S. Environmental Protection Agency), 12 ${ }^{\text {th }}$ (Arizona State Univ.), 15 $5^{\text {th }}$ (North Carolina State Univ.), and $19^{\text {th }}$ (CH2M Hill Inc.). Although the literature does not place PRC with a history of publications, Tsinghua Univ. takes the $4^{\text {th }}$ place and China Agriculture Univ., as $8^{\text {th }}$. Among the European 
universities, the Austrian Univ. of Innsbruk stands in $14^{\text {th }}$, the Swedish Lulea Univ. of Technology in $17^{\text {th }}$, and the Danish Univ. of Copenhagen in $18^{\text {th }}$.

\subsubsection{Relationship between research themes}

The 22 themes assessed in terms of the internal and external relationships are shown in Figure 2.6. The relationships built on similar themes are quantified in the diagonal, highlighted in black in the matrix. These relationships are important to evaluate a discussion concentration levels within each theme.

In the upper right frame of the matrix (Figure 2.6) lie the five most densely related themes. Faced with the set of relationally evaluated themes, the subgroup - formed by (3) Bioretention, (2) Best management practices (BMPs), (9) Low impact development (8) Integrated urban water management, and (15) Stormwater management - is considered core in the discussions about SUD. The themes (2) Best management and (8) Integrated urban water stand out as internal cohesive elements in the discussion, while (15) Stormwater management stands out as the most important intermediate topic in the central themes set.

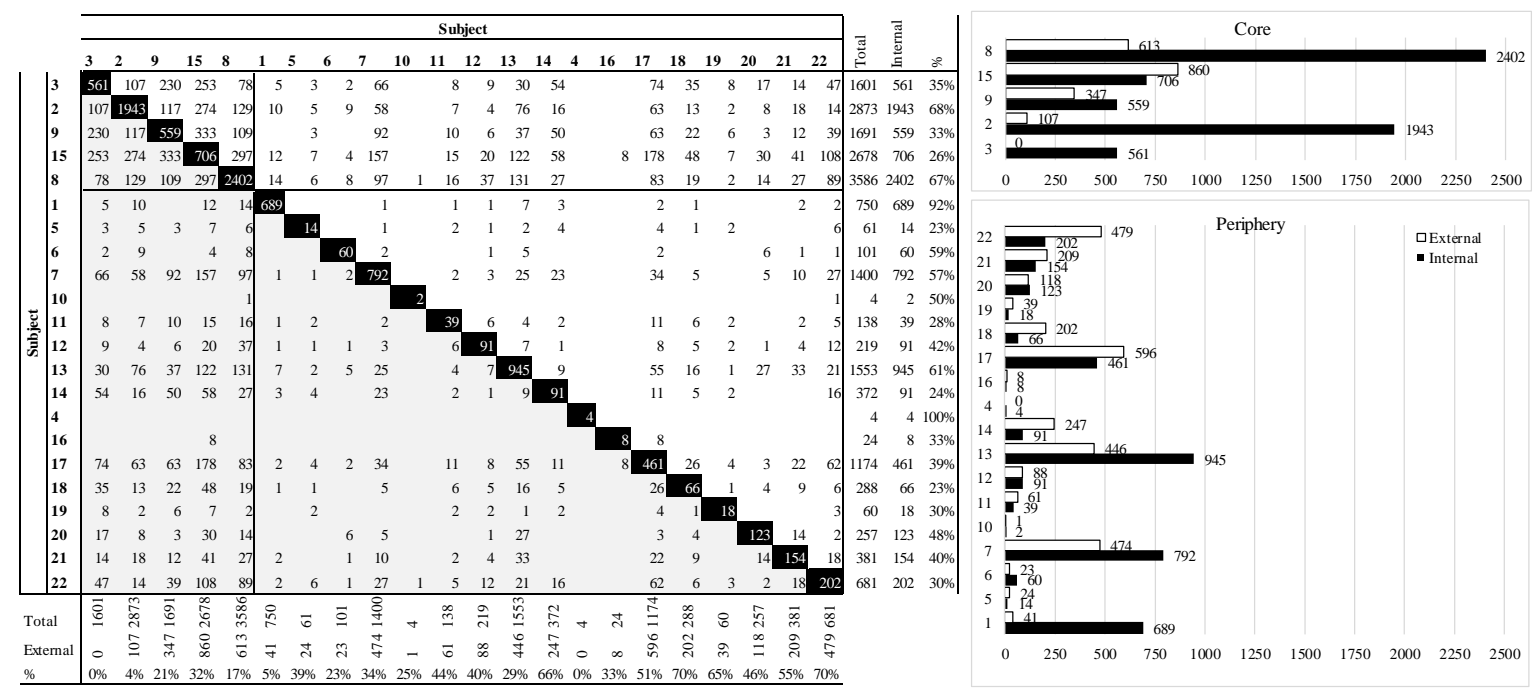

Figure 2.6 - Core and peripheral themes of the net

In the above matrix, the data found above and below the diagonal are symmetric; thus, in terms of the analysis, location on either side of the diagonal does not make a difference. These data assist in the evaluation of diversity of terms. This evaluation helps identify research gaps in the reviewed literature.

Some of the peripheral themes include: (7) Green infrastructure and (13) Source control; and these themes assume a leading role in discussions for they concentrate the 
number of intra-thematic relations. The themes (17) Stormwater quality and (22) Water Sensitive Urban Design are easily identified as nodal elements of external thematic relationships, and in effect, serve as a focal points in the network for important themes.

The core-periphery model, using the continuous method, indicated a correlation coefficient of 0.971 and Gini index of 0.625 . The model re-concentrated as core members the first five themes, with a correlation of 0.838 . When only external relationships of the institutions were considered, correlation was reduced to 0.236. The Gini index remained similar to the previous evaluation, as did the number of core authors. The centralization indices of the themes were not changed in both evaluations. A diagram of the classification of themes is provided in Figure 2.7.

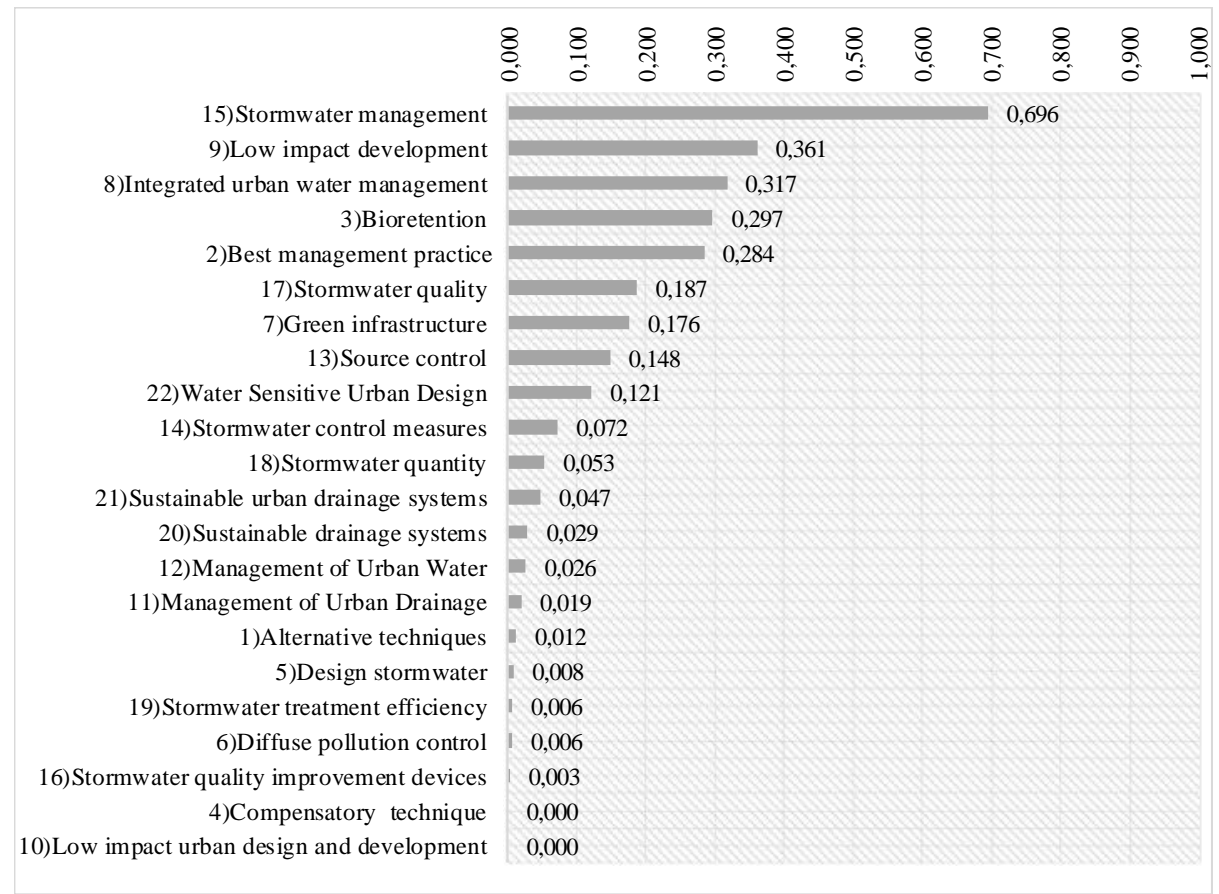

Figure 2.7 - Expressions searched in the Web of Science base

Historically, SUD research has focused upon hydraulic treatment to conduct superficial flow, resulting in the conception of drainage systems based on conduits (Pompêo, 2000). That started to change in the 90 s, when experience and adaptation of compensatory techniques received more attention by research groups from Europe, USA and Australia. Currently this new approach has provoked reflections and pointed to a paradigm shift in the urban drainage area. The Figure 2.7 brings a ranking of themes that takes prominent position related to urban drainage management practices, techniques and technologies of adaptive methods. This set of novel concepts has in common the same principles and types of solution, 
being those structural and/or non-structural, Generally, the principles are the same, the goal is to maintain the natural water cycle and improve sustainability.

\subsubsection{Relationships of centrality among author}

The global network of researchers in the SUD is shown in Figure 2.8. The network formed by the core authors is highlighted in black. According to the results of the Core/Periphery model, using the categorical method, the core authors network is comprised by Fletcher, TD; Deletic, A; Rauch, W; McCarthy, DT; Hatt, BE; Kleidorfer, M; Sitzenfrei, R; Bach, PM; and Urich, C. The density of relationships between the core authors was of 7.083 while for the peripheral model, was 0.001 .

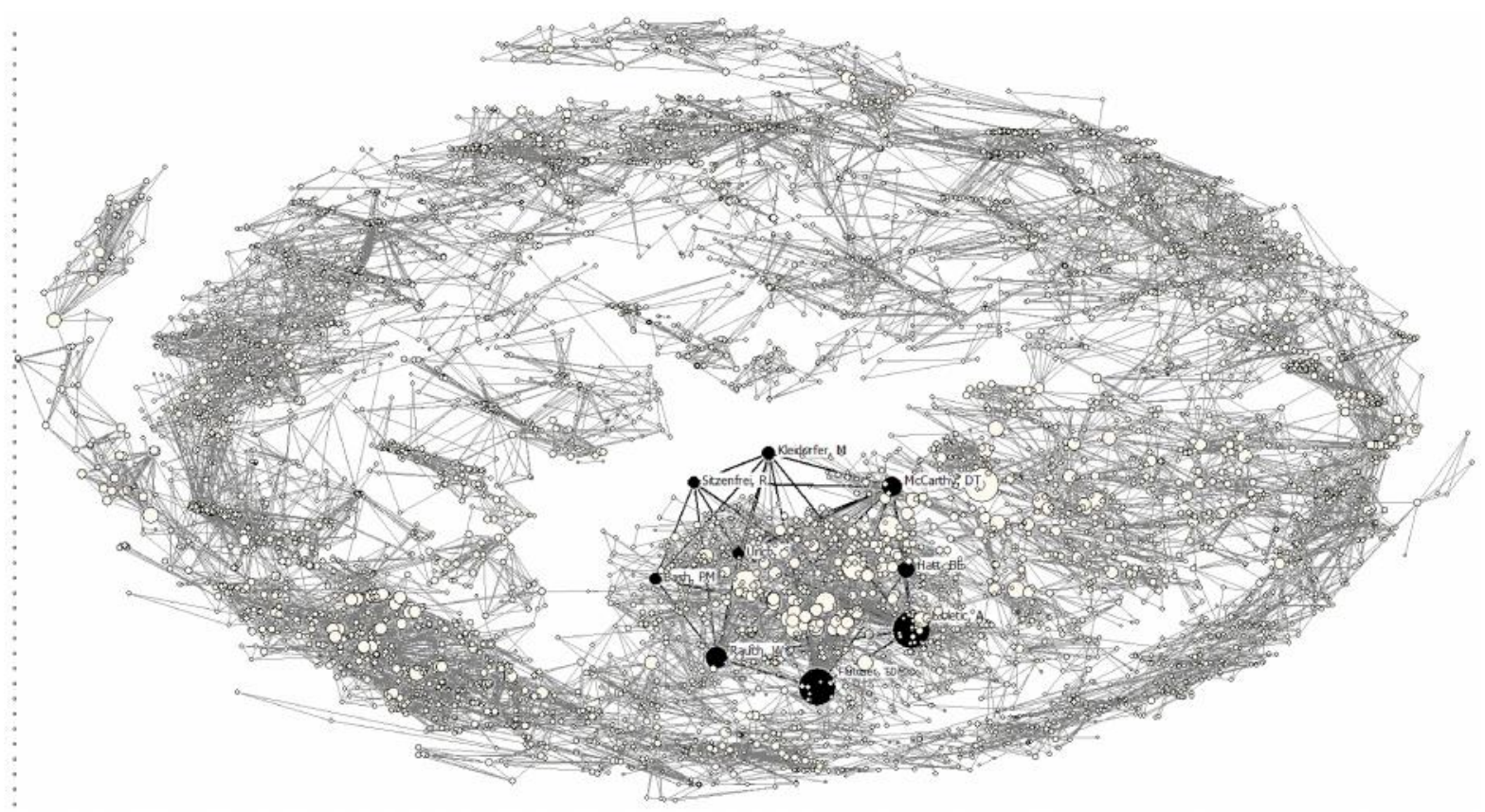

Figure 2.8 - Global authors network

The relationships between core authors shown in Figure 2.8 are detailed and quantified in Figure 2.9. In these two networks, the node size is proportional to the degree of centrality of each author. 


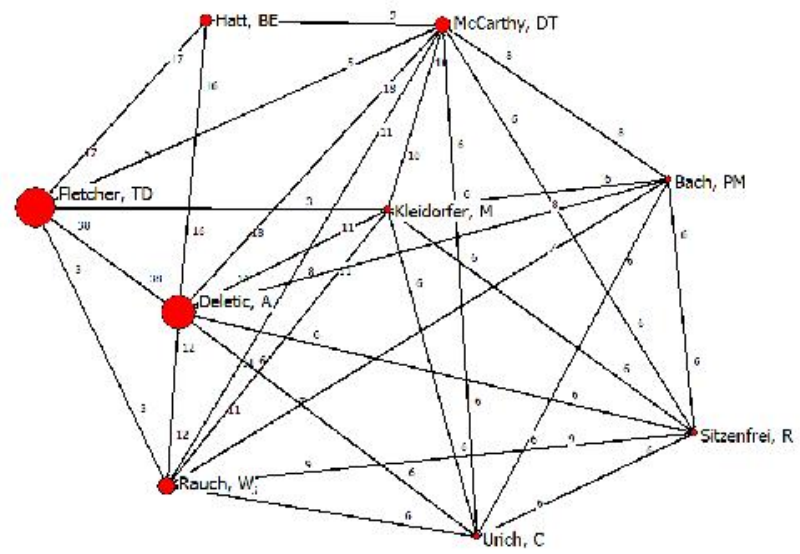

Figure 2.9 - Core authors network

Table 2.2 complements the data presented in Figure 2.9 with data from the affiliation and publication history. This set of authors that takes a core position in the network belongs to four universities, which also stood out in Figure 2.9. The majority of the authors has a publication history of approximately two decades.

\begin{tabular}{lllll}
\hline Author & Filiation & Start & Publications & Citations \\
\hline Rauch, W & University of Innsbruc & 1996 & 15 & 6305 \\
Fletcher,TD & The Univ. of Melbourne and Monash Univ. & 1996 & 10 & 2292 \\
Deletic, A & Monash Univ. & 1997 & 11 & 1804 \\
Hatt, BE & Monash Univ. & 1996 & 2 & 671 \\
McCarthy, DT & Monash Univ. & 1996 & 8 & 361 \\
Kleidorfer, M & Minnesota Univ. & 2007 & 5 & 193 \\
Bach, PM & Monash Univ. & 1996 & 2 & 180 \\
Urich, C & Monash Univ. & 1996 & 3 & 106 \\
Sitzenfrei, R & Univ. of Innsbruck & 2009 & 3 & 84 \\
\hline
\end{tabular}

Table 2.2 - History of publications of core authors

The classification of authors through the continuous method is shown in Figure 2.10, when Gini index was of 0.961 , and the concentration index of 0.880 . In this chart, the group of authors considered core are easily identified by the point of abrupt drop of the centrality indices.

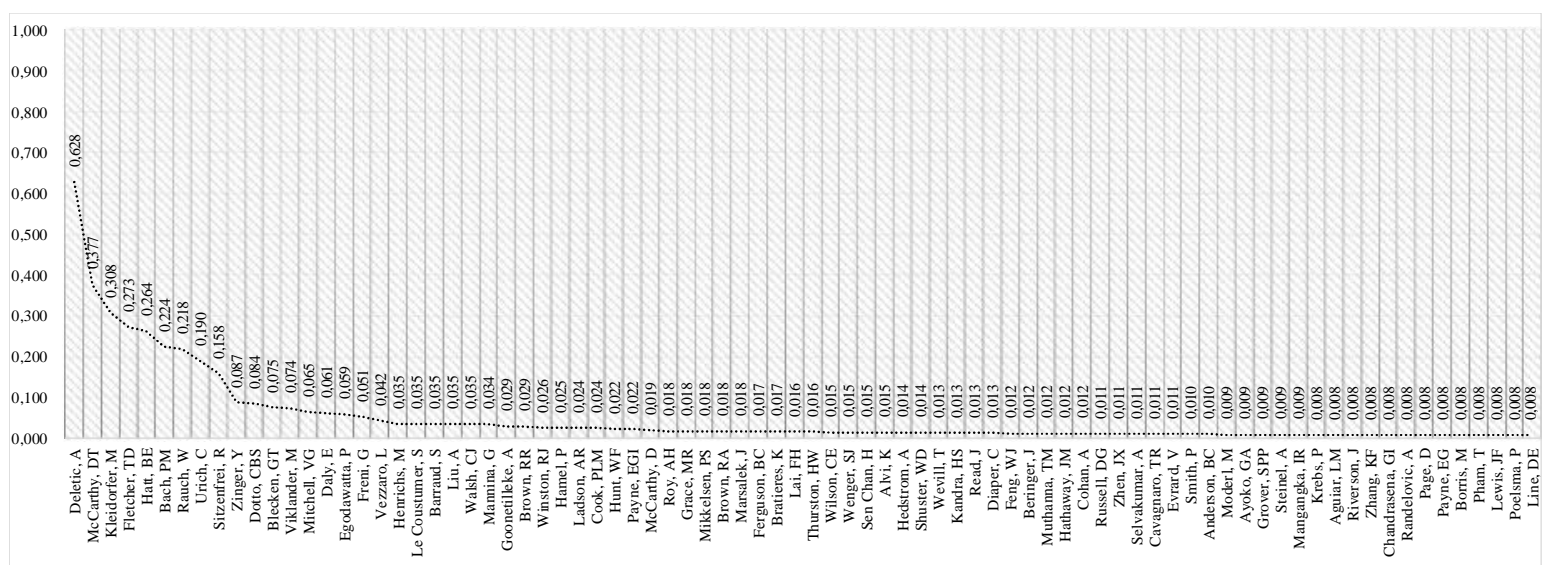

Figure 2.10 - Authors centrality 
With the purpose of exploring structures underlying the network shown above, the Figure 2.11 represents all authors with degree equal or greater than 10. This set of authors, formed by 21 communities, is comprised of 543 authors and 4826 relationships. The nodes identified in black represent the principal authors, classified according to the core-periphery model.

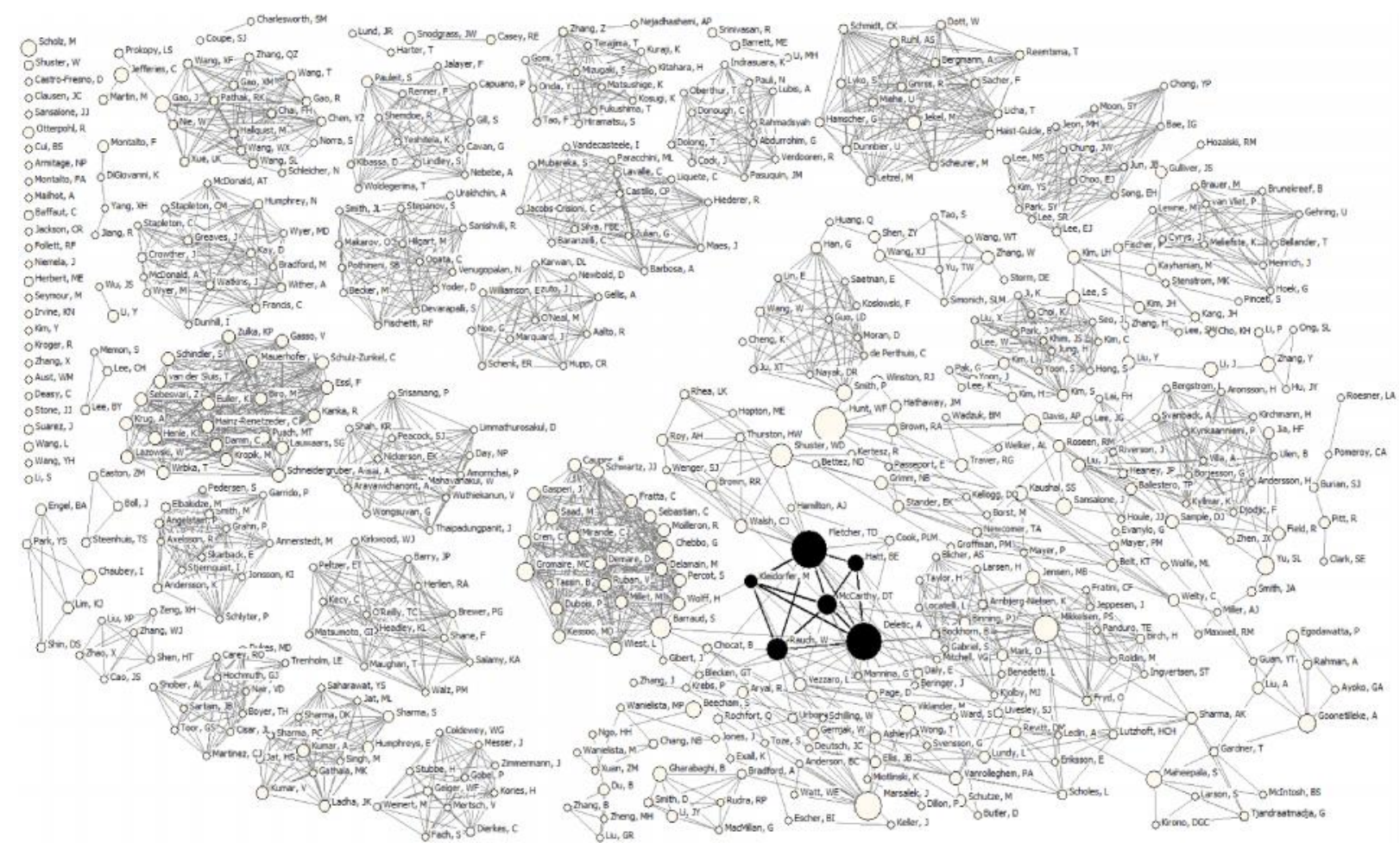

Figure 2.11 - Network of authors with degree higher than 10

In Figure 2.11, it is worth noting the broad network located in the bottom right corner is dominated by the core authors. Regarding the other smaller networks, interesting perspectives arise for investigations into which methods or interests structure the relationship between authors.

\subsubsection{Relationships of intermediation capacity}

The betweenness centrality index considers a network as a whole and is an expression of the capacity of each author to establish relationships between other two nonneighboring authors in the network. The relationships between the two non-neighboring authors depends on the intermediary authors, which implies that the latter has a greater influence over the social network. The authors with higher level of intermediation are 
considered core connectors because they provide the connection for a large number of authors in the network.

This metric enables the evaluation of importance of a particular author as a function of the flow passing by that author. The 70 authors with the highest intermediate centrality index in 2,012 relationships are shown in the network of Figure 2.12, with indices ranging from 249.2 to 2341.6 .

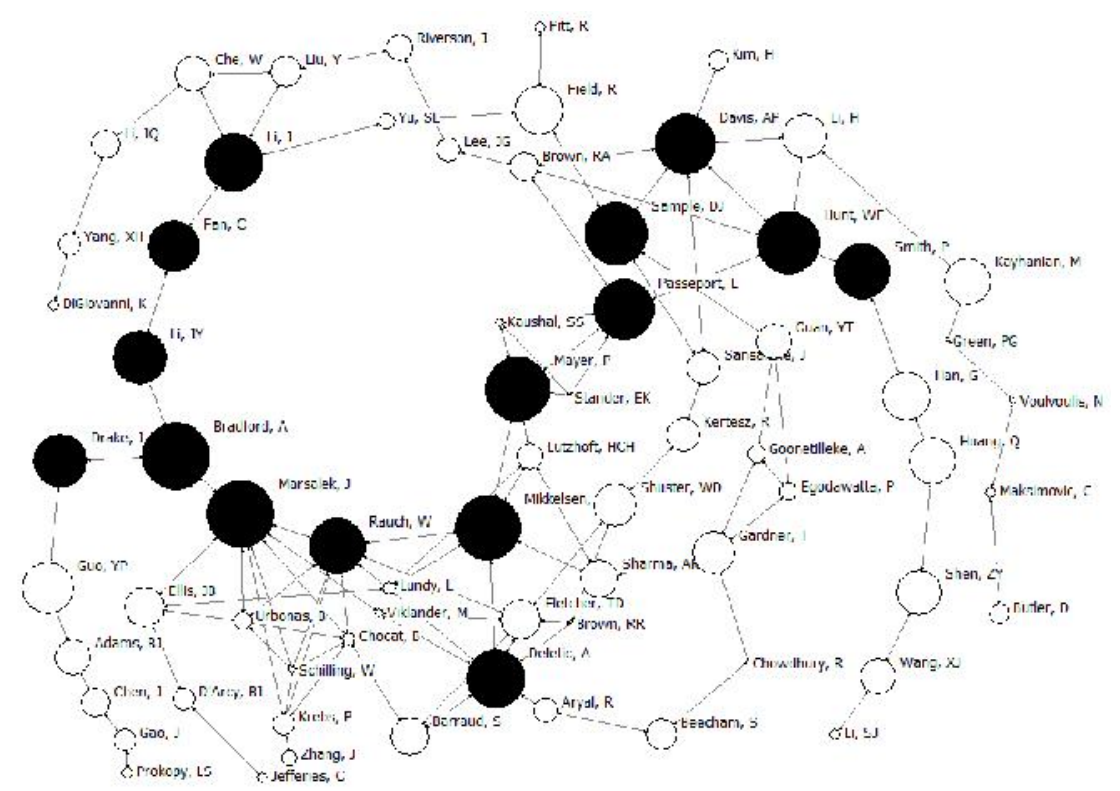

Figure 2.12 - Betweenness centrality

The 15 most relevant authors in terms of intermediation centrality are Marsalek, J (2,341.6), Bradford, A (2,291. 2), Meyer, P (2,078.3), Mikkelsen, PS (1,901.4), Hunt, WF (1,770.8), Sample, DJ (1,677.3), Pesseport, E (1,650.6), Davis, AP (1,509.8), Li, J (1,505.1), Deletic, A (1,482.3), Rauch, W (1,374.8), Smith, P (1,254.9), Drake, J (1,242.0), Li, JY $(1,225.9)$, Fran, $C(1,205.7)$. In the intermediation network, the authors are identified as strategically located in a central position within the network; and they have an important role in the flux by their capacity to concentrate and make directly available information of other authors. They are authors that facilitate direct contact with many others without the necessity of intermediates, and exert important influence in the network information flux.

\subsection{Conclusions}

The sociometric and bibliometric techniques described in this paper helped identify, map and objectively evaluate the domain formed by scientific publications related to a set of 
22 themes related to SUD, involving researchers from 82 countries, 2,027 research centers, 8,237 authors interacting through 11,857 citation relationships. In this domain, $72 \%$ of the relationships occurred between authors from European and North American countries.

The research supporting SUDS has drawn attention from a large number of countries. From the results, it can be inferred that the central locations, in terms of relationships between researchers and research centers, are USA, Australia, Canada, England, and Germany. When the internal relationships of each author of each location are considered, the PRC takes the second place among the core countries. Considering the great number of authors that articulate themselves in a large international, it is difficult to generalize tendencies in the area guided only by the geographical location of the authors of seminal texts. On the other hand, the domain shows that, if there are such pretensions, research should be expanded to capture local and regional nuances to fully explore SUD. From that expanded domain, generalizations would become more realistic.

Among the 8,237 authors, the ones considered as core authors in terms of density of citation relationships with authors from other countries are Fletcher, TD; Deletic, A; Rauch, W; McCarthy, DT; Hatt, BE; Kleidorfer, M; Sitzenfrei, R; Bach, PM; and Urich, C. Although these pose as references to the domain due to their relationships in the central network, there are other authors that stand out with relevant levels of leadership in 20 smaller networks. Moreover, if the evaluation is accomplished under the perspective of intermediation, the 15 most relevant authors are Marsalek, J; Bradford, A; Meyer, P; Mikkelsen, OS; Hunt, WF; Sample, DJ; Pesseport, E; Davis, AP; Li, J; Deletic, A; Rauch, W; Smith, P; Drake; Li, JY; and Fran, C. While authors from the first core group dominates in terms of strong relationships among each other, mainly because they belong to a selective group of 4 universities, the second group stand out because their publications broaden the reach of SUD knowledge produced by other authors.

The majority of research conducted on SUD has been conducted within developed countries. That probably derives from the investment capability of these countries and their concerns with alternative solutions based on the SUD perspective, assigning greater importance to the environmental issues. The low participation of African and South-American countries, which provided only $2 \%$ of the citation relationships, can be explained by the lower priority environmental issues may have in developing countries. However, it may represent a missed research and development opportunity if not corrected.

The most active themes in the academic community included: Stormwater management, Low impact development, Integrated urban water management, bioretention 
and best management practice. The nuclear position of these themes may indicate interesting paths to future research regarding SUD and may suggest analytical efforts to try to unify the nomenclature and form a domain of scientific research. The formation of a domain would facilitate, on the one hand, a deepening of research, and on the other hand, bring benefits to policymakers so they may understand and justify public policies based on a more consistent theoretical diagnosis about how important it is to follow up such references on SUD.

In the present research, it was verified that the Brazilian researchers appear isolated, not getting any prominence in any of the connections presented. This may occur because of the different terminologies used from those considered in this study. Also, this groups have published in other languages than English or because Brazilian academic production is not indexed in the platform web of Science. The language variable can be a considerable limitation, even if the possibilities of articles written in a language other than English have a very low probability of being cited in the international scientific community, which uses English as the basis for scientific communication in studies on the subjects covered by this research. However, before being a limitation, this last hypothesis can be seen as an important discovery that can be evaluated by the methodology developed, for example, by expanding the databases used in future research. This could open interesting ways to objectively evaluate whether such limitation arises from the intentional strategy of the Brazilian scientific community to refrain from publishing in English or from a limitation imposed by the English language as a barrier to international insertion.

\section{Acknowledgements}

The authors acknowledge the support of projects: (1) MAPLU2 - Stormwater Management in Urban Environment/FINEP, (2) Thematic Project 2008/15161-1 FAPESP "Assessment of Impacts and Vulnerability to Climate Change in Brazil and Strategies for Adaptation Options" (3) Casadinho/PROCAD CNPq 552494/2011-9 (UFAL-EESC / USP) "Advanced monitoring of biotechnological processes and environmental quality" and (4) CNPq 307637/2012-3 of Scientific Productivity. FAPESP 2013/06611-1 Detention and Biorretention for Control of the Diffuse Pollution in the Urban Drainage: Approach Experimentaladaptativa by Ecohydrologic Base.

\section{References}

ARGAS-QUESADA, B., \& de MOYA-ANEGÓN, F. (2007). Visualizing the structure of science. New York: Springer-Verlag.

BEGUM, S., RASUL, M. G., \& BROWN, R. J. (2008). A comparative review of stormwater treatment and reuse techniques with a new approach: Green Gully. WSEAS Transactions 
on environment and development.

BORGATTI, S. P., \& EVERETT, M. G. (1999). Models of core/periphery structures. Social Network.

BORGATTI, S. P., EVERETTI, M. G., \& FREEMAN, L. C. (2002). Ucinet 6 for social Network Analysis (Version 6.487). Needham: Analytic Technologies.

BROWN, R. (2005). Impediments to Integrated Urban Stormwater Management: The Need for Institutional Reform. Environmental management, 36(3), 455-468.

BROWN, R. A., \& HUNT III, W. F. (2010). Impacts of Construction Activity on Bioretention Performance. Journal of Hydrologic Engineering, 15(6), 386-394.

DAVIS, A. P. (2008). Field Performance of Bioretention: Hydrology Impacts. Journal of Hydrologic Engineering, 13(2), 90-95.

DAVIS, A. P., HUNT, W. F., TRAVER, R. G., \& CLAR, M. (2009). Bioretention Technology: Overview of Current Practice and Future Needs. J.of Envir. Engineering..

FLETCHER, T. D., ANDRIEU, H., \& HAMEL, P. (2013). Understanding, management and modelling of urban hydrology and its consequences for receiving waters: A state of the art. Advances in Water Resources, 51, 261-279.

FLETCHER, T. D., SHUSTER, W., HUNT, W. F., ASHLEY, R., BUTLER, D., ARTHUR, S., VIKLANDER, M. (2014). SUDS, LID, BMPs, WSUD and more - The evolution and application of Terminology surrounding urban drainage. Urban Water Journal.

GELDOF, G. D. (1995). Adaptive water management: Integrated water management on the edge of chaos. Water Science and Technology, 32(1), 7-13.

GELDOF, G. D. (2005). Coping with complexity in integrated water management: on the road to interactive implementation. Deventer: Tauw.

HANNEMAN, R. A., \& Riddle, M. (2005). Introduction to social Network methods. Riverside: University of California.

HJØRLAND, B., \& ALBRECHTSEN, H. (1995). Toward a new horizon in information science: Domain-analysis. Journal of the American Society for Information Science.

HOOD, W. W., \& WILSON, C. S. (2000). The literature of bibliometrics, scientometrics, and informetrics. Scientometrics, 52(2), 291-314.

JEFFREY, P., \& GEAREY, M. (2006). Integrated water resources management: lost on the road from ambition to realisation? Water Science \& Technology, 53(1), 1-8.

KUHN, T. S. (2000). A estrutura das revoluções científicas (5ª ed.). SP: Ed. Perspectiva.

LEE, S., \& YIGITCANLAR, T. (2010). Sustainable urban stormwater management : water sensitive urban design perceptions, drivers and barriers. In T. Yigitcanlar (Ed.), Rethinking Sustainable Development : Urban Management, Engineering, and Design.

LUCAS, W. C., \& SAMPLE, D. J. (2015). Reducing combined sewer overflows by using outlet controls for Green Stormwater Infrastructure: Case study in Richmond, Virginia. $J$. Hydrology.

NEWMAN, A. P., AITKEN, D., \& ANTIZAR-LADISLAO, B. (2013). Stormwater quality performance of a macro-pervious pavement car park installation equipped with channel drain based oil and silt retention devices. Water Research, 47(20), 7327-7336.

PANAGOPOULOS, Y., MAKROPOULOS, C., \& MIMIKOU, M. (2013). Multi-objective optimization for diffuse pollution control at zero cost. Soil Use and Management.

PARK, M., CHUNG, G., YOO, C., \& KIM, J.-H. (2012). Optimal design of stormwater detention basin using the genetic algorithm. KSCE Journal of Civil Engineering.

POMPÊO, C. A. (2000). Sustainable Urban Drainage. Brazilian J. of Water Resources. RS.

PRICE, D. D. S. (1976). O desenvolvimento da ciência: análise histórica, filosófica, sociológica e econômica. RJ: Livros Técnicos e Científicos.

PROCOPIUCK, M., \& ROSA, A. (2015). Evaluation of communities' perception on public policies, urban rivers functions, and qualities: the Belém River case in Curitiba. Urban 
Water $J$.

ROSEEN, R. M., BALleStero, T. P., HOUle, J. J., AVELlanedA, P., BRIGGS, J., FOWLER, G., \& WILDEY, R. (2009). Seasonal Performance Variations for Storm-Water Management Systems in Cold Climate Conditions. J. of Env. Engineering.

SAMPLE, D. J., GRIZZARD, T. J., SANSALONE, J., DAVIS, A. P., ROSEEN, R. M., \& WALKER, J. (2012). Assessing performance of manufactured treatment devices for the removal of phosphorus from urban stormwater. Journal of Environmental Management.

SAMPLE, D. J., \& LIU, J. (2014). Optimizing rainwater harvesting systems for the dual purposes of water supply and runoff capture. Journal of Cleaner Production, 75, 174-194.

SCOTT, J. (2000). Social Network Analysis: a handbook (2a ed.). Thousand Oaks: Sage Pub.

SCOTT, T. J., POLITTE, A., SAATHOFF, S., COLLARD, S., BERGLUND, E., BARBOUR, J., \& SPRINTSON, A. (2014). An evaluation of the Stormwater Footprint Calculator and the Hydrological Footprint Residence for communicating about sustainability in stormwater management. Sustainability: Science, Practice, \& Policy.

SEARCH TECHNOLOGY. (2006). VantagePoint (Version 5.0.10506): Search Technology.

SHARMA, A. K., GRAY, S., DIAPER, C., LISTON, P., \& HOWE, C. (2008). Assessing integrated water management options for urban developments: Canberra case study. Urban Water Journal, 5(2), 147-159.

ZAKARIA, N. A., AB GHANI, A., ABDULLAH, R., MOHD. SIDEK, L., \& AINAN, A. (2003). Bio ecological drainage system (BIOECODS) for water quantity and quality control. International Journal of River Basin Management, 1(3), 237-251.

ZHANG, R., ZHOU, W., LI, J., \& YU, S. (2010). Field evaluation of an innovative stormwater treatment device: the StormvaultTM system. Environmental Monitoring and Assessment.

ZHOU, Q. (2014). A review of sustainable urban drainage systems considering the climate change and urbanization impacts. Water, 6, 976-992. 


\title{
3. MODULAR SIZING FOR BIORETENTION SYSTEMS TO URBAN SCENARIOS CONSIDERING TIME SCALE AND INCREASING URBANIZATION - A CASE STUDY IN THE CITY OF SÃO CARLOS, BRAZIL*
}

*ROSA, A.; MACEDO, M. B.; SAMPLE, D.; SOUZA, V. C. B.; MENDIONDO, E. M. Modular sizing for bioretention systems to urban scenarios considering time scale and increasing urbanization - a case study in the city of São Carlos, Brazil. Submitted to Journal of Hydrology. Protocolo HYDROL21595

\begin{abstract}
Especially after the 90s, the literature and research addressing the theme of sustainable urban drainage systems have expanded. However, there is still a gap in the supply of bioretention systems sizing methods that consider the characteristics and climatic conditions of different regions where these practices are to be implemented. This paper presents a new bioretention sizing methodology called BIoREteNtIon CEll method - BIRENICE, with a focus in subtropical climates. The method presents, as innovation, the modular sizing with simulation scenarios. The methodology details the sizing and simulation method proposed by BIRENICE. A case study with a bioretention field application was made for a microcatchment at Campus 2 of University of São Paulo, in São Carlos, Brazil. We then compared the results with HEC-HMS (Hydrologic Modeling System - Hydrologic Modeling System), an already consolidated model. The proposed model, BIRENICE, makes possible to calculate the dimensions of a bioretention cell for future scenarios. The simulation module presented the water balance behavior over time, allowing the confirmation of the sizing. The results demonstrate that the simulations for BIRENICE method are accurate and have a similar behavior with HEC-HMS. In addition, BIRENICE shows that the stored volume decays by percolation over time, while in HEC-HMS, this loss is not estimated in reservoirs. By comparison, the sizing and simulation method proposed, BIRENICE, has little difference in front of results found with HEC-HMS, showing its applicability. For further research, we recommend to monitor bioretention cell in field for comparing actual data with simulated data by the proposed method.
\end{abstract}

Keywords - LID, urban drainage, stormwater practice design, subtropical

\subsection{Introduction}

According to Pômpeo (2000), in Brazil, urban drainage and runoff treatment have been focused on hydraulic conveyance, which remains the prevailing design objective. Traditional stormwater drainage has been found to be incapable of handling the impacts of urban development (Dietz, Clausen, 2008). Therefore, the development of alternative technologies emerged to deal with the impacts of urbanization. As an alternative to traditional drainage measures, Low Impact Development (LID) practices have emerged and have become increasingly popular (Sample \& Liu, 2014). LID practices handles urbanization impacts in a holistic manner and seeks to counterbalance their effects systematically. Recently, the conservation of the water balance prior to urbanization has been a relevant focus 
and is employed by reducing impermeable surface creation and increasing infiltration through a variety of means. LID practices also reduces runoff volume and slows the speed as the volume moves downstream (Prince George's County, 2000). Baptista et al. (2005) presented an overview of types and operation of several LID practices. Those alternative technologies for urban drainage, which are focused on low impact and sustainable urban drainage, have other names according to different authors, such as: Alternative Techniques (Fletcher et al., 2014); Best Management Practices (BMP) (Davis et al., 2009; Fletcher et al., 2014; Zhou, 2014); Compensatory Techniques (Fletcher et al., 2014); Diffuse Pollution Control (Panagopoulos et al., 2013); Management of Urban Drainage (Fletcher et al., 2014); Sustainable Urban Drainage Systems (SUDS) (Fletcher et al., 2014; Zhou, 2014), and Water Sensitive Urban Design (WSUD) (Davis et al., 2009; Fletcher et al., 2014; Lee \& Yigitcanlar, 2010; Sharma et al., 2008). However, the most common terms are LID, BMP, WSUD e SUDS.

The practices within LID technologies can be applied in three major scales: font control, micro drainage and macro drainage (Marsalekk and Schereier, 2009). A great number of practices, such as infiltration trenches, permeable pavements and green roof are usually employed in a large scale with a better interaction between user and technology. The bioretention practices, on the other hand, are also known as rain gardens, and even though they can be used in a large scale they are a good option for micro-drainage (Sample et al., 2013). Two treatment processes within the bioretention practices are filtration and infiltration (Erickson et al., 2013), which contribute to both water retention as well as the treatment of the water runoff quality (Sample et al., 2013).

Although there are over two decades of studies in LID operation and sizing, most studies have been focused upon hydrologic performance and water quality limited to the laboratory-scale, once field studies are more difficult, more expensive and harder to isolate single variables (Liu et al., 2014). There also remain gaps on how to predict the hydrologic effectiveness and water quality of bioretention (Lucas \& Sample, 2015). Additionally, little has been conducted in subtropical climates, which presents distinct hydrologic characteristics with high temperatures and evapotranspiration rates. Nonetheless, developing countries are located in these regions, which have different socioeconomic conditions, large urban agglomerations and megacities associated with a lack of urban planning and economic contrasts. There is a lack of understanding in the basic physical processes through which LID practices actually works when applied in field (interaction with the user, visual integration issues, waste and water quality issues, and potential risk of environmental degradation) (Liu et 
al., 2014, Sample \& Liu, 2014). A particular need is to concern the sizing issue, i.e., what size is appropriate for a real watershed (Roy-Poirier et al., 2010).

Many authors have been working on developing models, simulations and standardized methods and parameters aiming at a proper evaluation and design of LID practices. Elliott \& Trowsdale (2007) reviewed appropriate evaluation models for SUDS, LID, BMPs, WSUD and more. Winston et al. (2011), Lintern et al. (2011) and Fletcher et al. (2015) discussed how to choose the key parameters that can be used as a sizing criteria and its influence in bioretention performance and useful life. In Brazil, Souza et al. (2011) adapted a rainfall-runoff model to simulate LID practices in urban drainage systems under different mitigation scenarios.

Table 3.1, adapted from Liu et al. (2014), presents different models used to simulate and measure LID practices, including bioretention. The first column on the left brings the model used; the middle column describes briefly the model; and the right column cites some researchers that have used the correspondent model on their research. The models SWMM, HEC-HMS, RECARGA and DRAINMOD present the advantage of being public-domain, which makes its acquisition easier. The DRAINMOD and RECARGA are less used models once the first was originally developed to simulate agricultural fields and has been adapted to bioretention and the last was developed to simulate a single bioretention cell. However, SWMM and HEC-HMS are hydrologic models employed for distinct purposes, including LID practices and bioretention and are more internationally supported. 


\begin{tabular}{|c|c|c|c|c|c|c|c|}
\hline Model & Brief description & Capabilities & Processing & LID application & References & $\begin{array}{c}\text { Quali-quantitative } \\
\text { assessment }\end{array}$ & $\begin{array}{l}\text { Spatio-temporal } \\
\text { Module Sizing }\end{array}$ \\
\hline SWMM & $\begin{array}{lr}\text { Public-domain; } & \text { hydrologic, } \\
\text { hydraulic and water quality model } \\
\text { with optional r continuous } \\
\text { simulation (note: several } \\
\text { proprietary, value-added versions } \\
\text { exist). }\end{array}$ & $\begin{array}{l}\text { Detailed analysis of watershed } \\
\text { with storage-focused LID }\end{array}$ & $\begin{array}{l}\text { Running under Windows, SWMM5; } \\
\text { running hydrologic, hydraulic and water } \\
\text { quality simulations; and viewing the results } \\
\text { in a variety of formats. USEPA version is } \\
\text { free, including code }\end{array}$ & Included & $\begin{array}{l}\text { Lucas (2010); Mais } \\
\text { (2011); Neilson \& } \\
\text { Turney (2010); Wang et } \\
\text { al. (2013); Aad et al. } \\
\text { (2010) }\end{array}$ & Yes & No \\
\hline Hydro-CAD & $\begin{array}{l}\text { Hydrologic model that uses a } \\
\text { design storm methodology to } \\
\text { calculate runoff and detention } \\
\text { pond routing with exfiltration } \\
\text { option. }\end{array}$ & $\begin{array}{l}\text { Analysis of storage and } \\
\text { infiltration based LID within a } \\
\text { watershed }\end{array}$ & $\begin{array}{l}\text { Running under Windows requires a CAD } \\
\text { software. analysis, design, and } \\
\text { documentation of complete drainage } \\
\text { systems using standard hydrograph } \\
\text { techniques. It is not free. }\end{array}$ & Not included & $\begin{array}{l}\text { Lucas (2010); Jacobson } \\
\text { (2011) }\end{array}$ & No & No \\
\hline HEC-HMS & $\begin{array}{l}\text { Public-domain; hydrologic model } \\
\text { to develop standard hydrograph } \\
\text { based on precipitation input. The } \\
\text { user can choose from several } \\
\text { hydrologic algorithms. }\end{array}$ & $\begin{array}{l}\text { It obtains standard, non-adjusted } \\
\text { hydrographs. Not recommended } \\
\text { for modelling integrated practices }\end{array}$ & $\begin{array}{l}\text { Simulate the precipitation-runoff processes } \\
\text { of dendritic drainage basins. Require faster } \\
\text { desktop computers for all operational } \\
\text { systems. The U.S. Army Corps of } \\
\text { Engineers version is free. }\end{array}$ & Not included & $\begin{array}{l}\text { Heasom et al. (2006); } \\
\text { Giacomoni et al. (2012); } \\
\text { He \& Davis (2011) }\end{array}$ & No & No \\
\hline RECARGA & $\begin{array}{l}\text { Public-domain; hydraulic model } \\
\text { of a single bioretention cell for an } \\
\text { event or continuous simulation. }\end{array}$ & $\begin{array}{l}\text { Detailed analysis for bioretention } \\
\text { hydraulics and runoff retention }\end{array}$ & $\begin{array}{l}\text { Evaluating the performance of bioretention } \\
\text { facilities, rain gardens, and infiltration } \\
\text { basins, running under Windows, fast } \\
\text { processing. It is s not free. }\end{array}$ & Included & $\begin{array}{l}\text { Wisconsin Department } \\
\text { of Natural Resources } \\
\text { (2004); Carpenter \& } \\
\text { Hallam (2010); Turney } \\
\text { \& Neilson (2010) }\end{array}$ & Yes & No \\
\hline DRAINMOD & $\begin{array}{l}\text { Public-domain hydrologic model } \\
\text { based upon agricultural field } \\
\text { drainage, and treatment, which is } \\
\text { to bioretention. }\end{array}$ & $\begin{array}{l}\text { It simulates water table and soil } \\
\text { moisture profile. }\end{array}$ & $\begin{array}{l}\text { Simulates the hydrology of poorly drained, } \\
\text { high water table soils on an hour-by-hour, } \\
\text { day-by-day basis for long periods of } \\
\text { climatological record, Running under } \\
\text { Windows. It is free. }\end{array}$ & Included & $\begin{array}{l}\text { Brown et al. (2013); } \\
\text { Bechtold et al. (2007); } \\
\text { Youssef et al. (2005) }\end{array}$ & No & No \\
\hline WinSLAMM & $\begin{array}{l}\text { The proprietary hydrologic model } \\
\text { that uses a derived distribution } \\
\text { based upon small storm hydrology } \\
\text { to simulate the performance of } \\
\text { controls. }\end{array}$ & $\begin{array}{l}\text { Pollutant washoff calculated } \\
\text { based upon land characteristics. } \\
\text { Model traces pollutants from } \\
\text { sources and predicts effects of } \\
\text { controls }\end{array}$ & $\begin{array}{l}\text { Evaluates runoff volume and pollution } \\
\text { loading for each source area within each } \\
\text { land use for each rainfall event, low } \\
\text { processing operational, running under } \\
\text { Windows. It is free. }\end{array}$ & Included & $\begin{array}{ll}\text { Pitt \& Voorhes } & (2004) ; \\
\text { Neilson \& } & \text { Turney } \\
\text { (2010); Talebi \& Pitt } \\
\text { (2012) }\end{array}$ & Yes & No \\
\hline IDEAL & $\begin{array}{l}\text { Hydrologic model that uses a } \\
\text { derived distribution to simulate } \\
\text { performance of controls, for both } \\
\text { quality and quantity. }\end{array}$ & $\begin{array}{l}\text { Process-based pollutant loading } \\
\text { and treatment model, includes } \\
\text { decay, settling and infiltration, } \\
\text { focused upon evaluation of a site } \\
\text { before and after development. }\end{array}$ & $\begin{array}{l}\text { Used for stormwater best management } \\
\text { practices (BMP) simulations and } \\
\text { calculating their effectiveness in removing } \\
\text { common stormwater pollutants. Low } \\
\text { processing operational, running under } \\
\text { Windows. It is not free. }\end{array}$ & Included & Alexander et al. (2011) & Yes & No \\
\hline WWHM & $\begin{array}{l}\text { Hydrologic model based upon } \\
\text { HSPF adapted for control practice } \\
\text { design using continuous } \\
\text { simulation. }\end{array}$ & $\begin{array}{l}\text { Calibrated regional parameters } \\
\text { for the } 19 \text { counties of Western } \\
\text { Washington, Version } 2012 \\
\text { includes modeling elements to } \\
\text { more accurately model } \\
\text { bioretention and other LID } \\
\text { practices. }\end{array}$ & $\begin{array}{l}\text { Helps scale projects with low processing for } \\
\text { all versions of Windows, using peak } \\
\text { discharge, duration and volume. It is free } \\
\text { and open code. }\end{array}$ & Included & Beyerlein (2011) & No & No \\
\hline BIRENICE & $\begin{array}{l}\text { Method to size a bioretention cell, } \\
\text { which has a computer-based } \\
\text { simulation module, using a simple } \\
\text { method known as loads detention, } \\
\text { to verify the dimensioning }\end{array}$ & $\begin{array}{l}\text { Integrated the detention and } \\
\text { bioretention process and is valid } \\
\text { for hydrological simulation. }\end{array}$ & $\begin{array}{l}\text { Developed in VBA (Visual Basic for } \\
\text { Applications) }\end{array}$ & $\begin{array}{l}\text { Just } \\
\text { Bioretention }\end{array}$ & $\begin{array}{l}\text { Developed by the } \\
\text { authors }\end{array}$ & No & Yes \\
\hline
\end{tabular}

Table 3.1 - Computational models and it assignments for simulation in alternative methods of urban drainage (Source: Liu et al., 2014) 
The integration of runoff performance and sizing methodology has recently been explored. Silveira and Goldenfum (2007) present a pre-sizing "general methodology" for LID practices. However, their methodology only considers quantitative aspects in peak flows and volume controls. Akan \& Houghtalen (2003) developed a detention basin sizing methodology that integrated sediment removal as assessed by total suspended solids (TSS), but no other water quality constituents.

Given the increasing adoption of biofilters and bioretention, it is critical that their size should incorporate key design parameters within an integrative approach. In this paper, we present a method to size a bioretention cell, which has a computer-based simulation module, using a simple method known as loads detention to verify the dimensioning. The proposed methodology considers the range of hydrological effects (Figure 3.1) guiding treatment processes from the individual lot to the micro drainage scale. Figure 3.1 shows the variables of the water balance and theirs expected temporal variation. Sizing is made based on the quantification of the cell storage volume, calculated by the difference between inflow and outflow hydrogram peak, in order to find the water balance as closely as possible to the pre urbanization period. The hydrograms used are obtained by the computer-based simulation module.
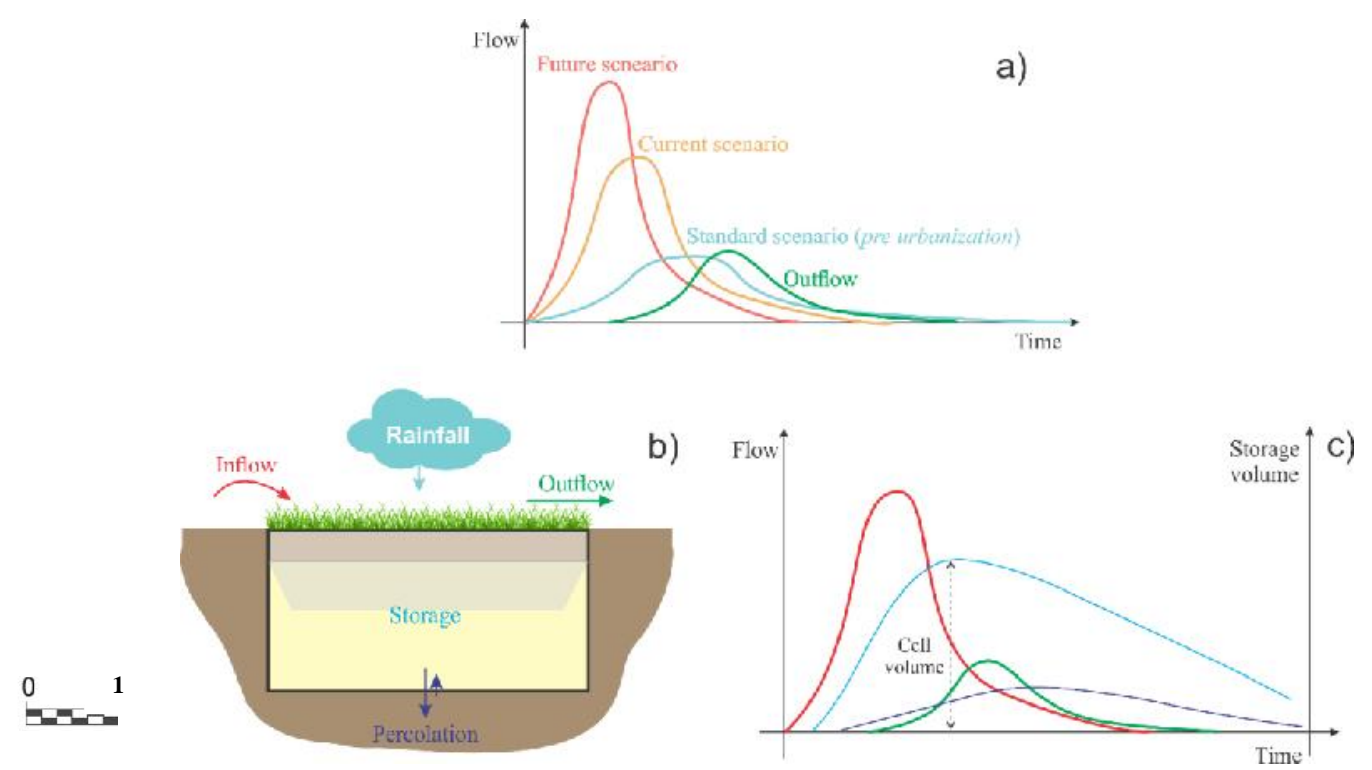

Figure 3.1 - Hydrograms for sizing scenarios and water balance to the proposed bioretention basin, with its inflow, storage and outflow variables. The line colours of the graph at (c) corresponds to the inputs and outputs represented in (b). In (b), it is possible to observe the temporal variation of each variable as it is the expected in the observation from the computer-based simulation. In (c), more specifically, it is possible to see the volume of the cell shown by the dotted lines, which is equivalent to the peak of the stored volume. After reaching the peak. it begins to be output flow by the spillway. 
As part of the innovation, we also propose the construction of bioretention cells using an incremental approach, as a time-adapted strategy to improve the overall life of bioretention structure. The method proposed is the construction of a bioretention cell structured to use multiple gradual scenarios as opposed to building a single structure to meet the final plan (Figure 3.2). Then, it is possible to develop a plan to supply the long-term demand with amortized costs during the lifetime of the work.

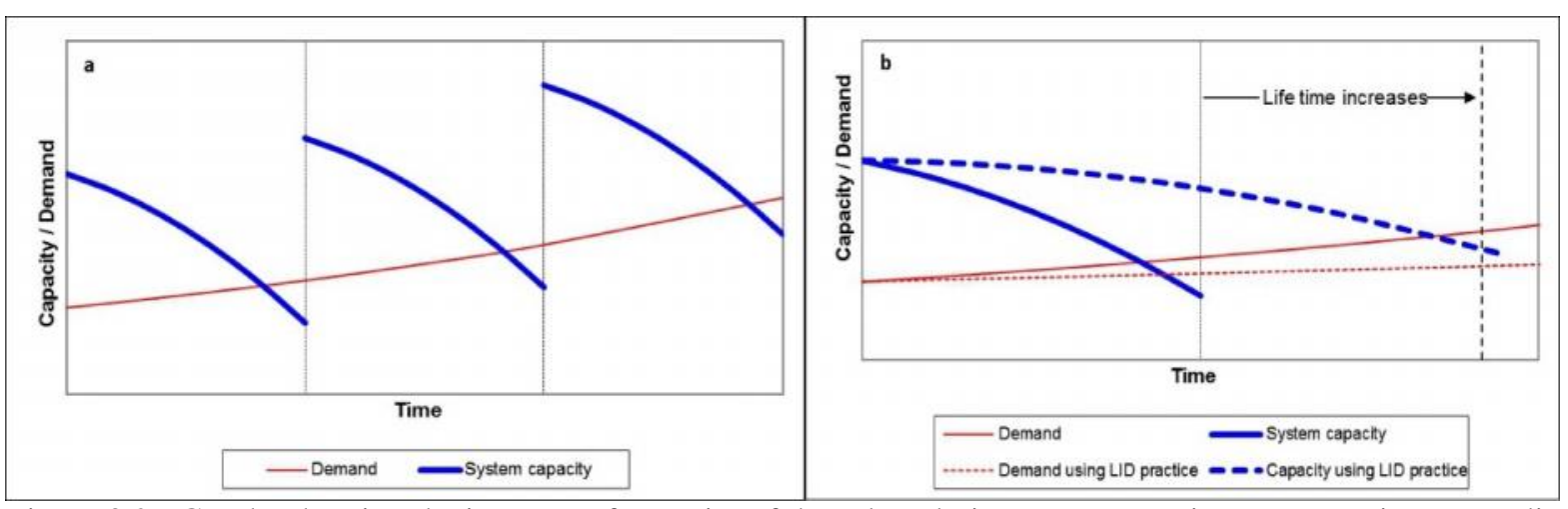

Figure 3.2 - Graphs showing the increase of capacity of the urban drainage system using LID practices according to its demand. In (a), we have the behavior of modular design, in which system capacity is increased by three different modules

Finally, it was developed a case study in an urban basin in the city of São Carlos to verify the real application of the model and the modular design. The model's performance is assessed and compared with another commonly accepted model, HEC-HMS, using designbased examples with a range of event-based simulation. With this comparison, we intend to show that the proposed model presents similar results as an established model, but it has the advantage of being focused on bioretention and ease to use, beyond enabling the user to make changes in the equation used for better meeting their goals.

\subsection{Methods}

In this section, it will be presented the conceptual methods of dimensioning proposed by many authors, directing to a discussion about the development of the model design and methodology. In order to verify its applicability, the developed model was compared to an established model (HEC-HMS) and a bioretention cell was built in the field. 


\subsubsection{Sizing theory}

Sizing by runoff retention ( $\left.V_{\text {mas, quanti, eff }} Q_{\text {quanti }}\right)$

For calculation purposes, we define the following mass variables as a function of time: $\mathrm{H}_{\mathrm{E}}$ as the accumulated water depth at the input and $\mathrm{H}_{\mathrm{S}}$ as accumulated water depth at the output, both of them are measured over the drainage area. The maximum potential treatment volume can be estimated by solving a set of equations (Eq. 3.1 - 4), obtained from Silveira \& Goldenfun (2007). See the illustrative scheme of parameters used in the sizing in appendix C.

$\mathrm{H}=\frac{V_{m} q}{\eta}=\left(\sqrt{a / 60 \beta} \times T^{\frac{b}{2}}-\sqrt{c / 60 \gamma q_{s}}\right)^{2}$

$\beta=\frac{C \times A}{B \times L}$

$\mathrm{q}_{\mathrm{s}}=q_{p}+\alpha \times K_{\mathrm{S}_{1}}$

$\operatorname{eff}_{\Delta Q_{q}}=\frac{\Delta P_{e}-q_{s} \times t_{r}}{\Delta P_{e}}$

Eq. 3.4

Where: Vmax quanti is the pre-sizing volume ( $\mathrm{mm}$ height equivalent) to mitigate excessive urban runoff volume. The total volume can be expressed as $V_{\text {bioretention }}=V \max _{\text {quanti }} \bullet A$, which can be simplified as Vbioretention $=h_{\max }$ - $A_{\text {bioretention }}$ (plant) $\approx h_{\max } \cdot A_{\text {biofilter }}$ (plant). $\beta$ is the runoff coefficient with the ratio between percolation area and implementation area; $A$ is the contribution area; $C$ is the runoff coefficient of contribution area; $L$ and $B$ represent length and width dimensions (m) and $\mathrm{T}$ represents return time (years); $\eta$ is the filler material porosity; $\gamma$ is the ratio between the percolation area and volume $(\mathrm{mm}) ; K_{\text {sat }}$ is the soil saturated hydraulic conductivity $\left(\mathrm{mm} \mathrm{h}^{-1}\right) ; \alpha$ is the infiltration efficiency reduction coefficient due to clogging and, finally, $q_{p r e}$ is the desired flow goal, which is an environmental or pre-development flow established in the Drainage Master Plan.

Sizing by pollution charge retention ( $V_{\left.\text {mas, quali, eff } Y_{\text {quali }}\right)}$

Quality parameters are normally incorporated based upon the methodology proposed by Akan \& Houghtalen (2003), and Hatt et al. (2009). The hypothesis considers a trial size based upon solids mass transport retention time ( $\mathrm{t}_{\mathrm{TSS}}$ quali-IN), derived from urban drainage, and the bioretention evacuation time ( $\mathrm{t}_{\mathrm{TSS}}$ quali-OUT), which set an extra volume, Vmax $x_{\text {quali. }}$ Akan \& Houghtalen (2003), and Hatt et al. (2009) discuss the relationship between Vmaxquali and output structure size and type using the set of Eq. 3.5 - 9. See the illustrative scheme of parameters used in the sizing in appendix $\mathrm{C}$.

$$
\begin{aligned}
& \mathrm{V}_{\mathrm{q}}=b_{q} \quad \times h^{c_{q}} \\
& \text { Eq. } 3.5 \\
& \mathrm{P}=\frac{k_{\mathrm{U}} a_{\mathrm{U}} \sqrt{2 g}}{i_{p}}\left(\frac{i_{p} \times t_{p}}{b_{q}}\right)^{0,5 / c_{q}} \quad \text { (Orifice output) }
\end{aligned}
$$


$\mathrm{P}=\frac{k_{w} L \sqrt{2 g}}{i_{p}}\left(\frac{i_{p} \times t_{p}}{b_{q}}\right)^{1,5 / c_{q}} \quad$ (Spillway output)

Eq.3.7

$\mathrm{W}=\frac{w_{9}}{t_{p}} ; R=\frac{T_{9}}{t_{p}} ; S_{u}=\frac{V_{m}, q}{i_{p} \times t_{p}} ; t_{d} \quad(j)=\frac{V_{m}, q}{u_{S}(j)}$

$\operatorname{eff}_{\Delta Y, q} \cong \operatorname{eff}_{\mathrm{r} \epsilon} \quad, 9 \% \Delta \mathrm{Y}=0,9 \sum_{j=1}^{N_{T}} \frac{t_{r_{i}}}{t_{d} \quad t \quad(j)}$

Where: $V_{\text {quali }}$ and $\mathrm{h}_{\text {quali }}^{\mathrm{c}}$ respectively represent the volume and the detention water depths for quality control measured at the outlet structure; $c_{\text {quali }}$ and $b_{\text {quali }}$ are considered parameters; $k_{o}$ is the dimensionless orifice discharge coefficient; $a_{o}$ is the orifice area; $g$ represents the gravitational acceleration, $i_{p}$ is the maximum input discharge, $t_{p}$ is the maximum discharge time; $k_{w}$ is the dimensionless discharge coefficient; $L$ represents the spillway width; $w_{90}$ is the period in which at least $90 \%$ of runoff will be held; $r_{90}$ as the time to which $90 \%$ of the flow will be evacuated; $V_{\max }$,quali is the maximum water detention volume; $t_{\text {retention }}$ is the required time for TSS retention; $t_{\text {detention }(j)}$ as the required detention time, and $u_{S T T}(j)$ represents the settling velocity of the TSS j-th fraction; and, finally, effremotion $90 \% \quad Y$ is the overall removal efficiency for $90 \%$ of diffuse pollution charged by TSS transport.

Sizing for bioretention device ( $V_{\text {mas,bio, }}$ eff $\left.x_{\text {bio }}\right)$

Eq. 3.10 to 13 constitute the set of equations, presented in the Technical Design Guidelines (McAuley, 2009), to estimate the efficiency of bioretention design. See the illustrative scheme of parameters used in the sizing in appendix $\mathrm{C}$.

$$
\begin{aligned}
& L_{b}=\frac{Q_{m}, \Delta P}{h_{m}\left(\frac{B_{h, f}}{t_{c}}+\frac{K_{s} \cdot B_{h, f}}{a_{b}}\right)} \\
& f_{m, b}=K_{S} \cdot L_{b} \quad \cdot B_{b} \cdot \frac{h_{m}+d_{b}}{d_{b} \quad l t} \\
& T_{b} \quad=\frac{L_{b}}{f_{h=0.5 m}} \cdot\left(\varnothing \cdot B_{b}+B_{h, f} \quad . h_{m}\right) \\
& \text { e. } \left.\Delta X, b=1-\left[1+\frac{1}{n} \cdot \frac{u_{S}}{Q_{m}, \Delta \mu / A_{b}} \cdot \frac{\left(h_{S}+h_{m}\right.}{\left(h_{m}+h_{m}\right.}\right)\right]^{-n}
\end{aligned}
$$

In wich: $L_{b i o}$ is the length of bioretention cell; $Q_{\max , \Delta \mathrm{Pe}}$ is the maximum discharge rate entering the bioretention cell, $B_{\mathrm{h}, \text { flooded }}$ and $B_{\text {bio }}$ respectively represent the mean width of the transversal flooded area and the width in bioretention cell; $K_{S}$ is the soil saturated hydraulic conductivity; $h_{\max }$ is the maximum flooding depth above the bioretention cell; $\mathrm{d}_{\text {biofilter }}$ is the biofilter depth; $t_{c}$ is the concentration time of contribution area; $f_{\mathrm{h}=0,5 \mathrm{hmax}}$ is the infiltration rate for water height equal to half of the maximum flooding depth; $\varnothing$ is the soil porosity; $n$ is a turbulence empirical hydraulic parameter proposed by Fair \& Geyer (1954). For preliminary design, it is recommended that it is assigned the value of 1.33 (PGC, 2009).

The bioretention efficiency eff $\Delta \mathrm{X}$,bio depends on the hydraulic loading rate, defined as the ratio between $Q_{\max , \Delta \mathrm{Pe}}$ and $A_{\text {bio, }}$ on $h_{S T T}$, defined as the biofilter clogging depth, and on $h_{\text {meta }}$, defined as an intermediate flooding depth to remove pollutants loads via filtration. The advantage of using specific bioretention equations is that it can incorporate parameters such as basin concentration time $\left(t_{c}\right)$ and hydraulic criteria for the hydrologic regime under which the bioretention is subjected to. 


\section{Sizing by computational simulation}

This fourth method integrates the detention and bioretention process and is valid for hydrological simulation. It is used the level pool flow lamination (PULS method) and total percolation in potential wet area (Aw), by the Green-Ampt method (Tucci 1993). The discharge structure in bioretention cell output is sized in order to preserve the predevelopment of water balance. Infiltration at the bottom and the sidewalls depends on the particle size and geometry of the soil that surrounds the device. Assuming the bioretention cell with rectangular area plant (ATC) and maximum depth $\left(\mathrm{h}_{\max , \mathrm{LID}}\right)$, the criterion is summarized as: optimize Vcell, hmaxLID and lip, subject to restrictions in Eq. 3.14 - 16.

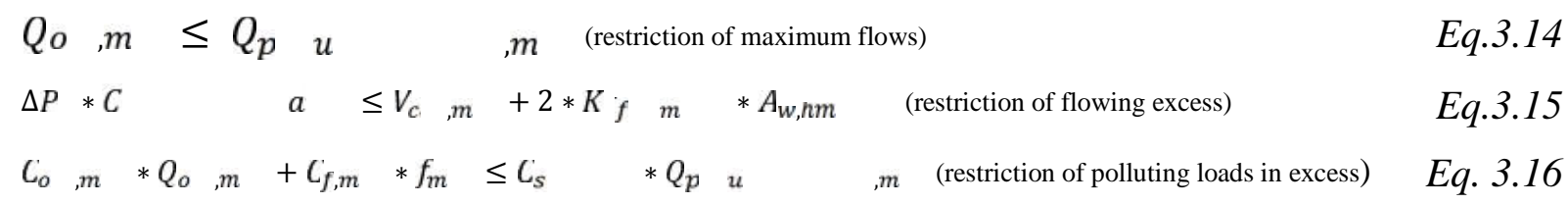

where: $C_{\text {out,max }} * Q_{\text {out,max }}$, max maximum pollution load (concentration $*$ flow) coming out of flow device, $\mathrm{C}_{\mathrm{f}, \max } * \mathrm{f}_{\max }$ the maximum pollutant load that seeps into the device and Cstandard $* \mathrm{C}_{\text {standard }} * \mathrm{Q}_{\text {preurbanization,max }}$, max maximum pollution load allowed the legal standard (see CONAMA 357/05).

\subsubsection{Bioretention Cell Method-BIRENICE}

Bioretention cells have multiple functions, including the reduction of runoff volume (by increasing infiltration), the reduction of peak runoff and the reduction of pollutants in discharge flows through both mass reduction and physical and biological treatment (LIU et $a l ., 2014)$, favoring the maintenance of water balance based on a pre urbanization period. Bioretention can affect both water quantity and quality. Predicting hydrological and water quality results, as a function of changing bioretention design parameters, is essential to improve performance.

To facilitate the design of a bioretention cell, we have developed a computational model to simulate the design, using unique parameters to each cell given its specific location. A key feature of the method is that it estimates the eventual size of the bioretention cell in multiple, cumulative scenarios. This enables the designer to select a variety of trial sizes and iteratively simulate each bioretention cells in steps, by setting the desired time intervals and the input parameters. 
The computational model, BIRENICE, was developed in VBA (Visual Basic for Applications). The BIRENICE method allows the adoption of two rain duration values as sizing criteria. In addition, the user can choose either a single design event or continuous simulation. In the simple mode, the structure simulation is done for a single design event, in continuous simulation; it is possible to simulate multiple events, creating a worksheet containing graphs for comparison of results from each simulated event. The model runs for the present time and, then, continues until the bioretention cell is completely drained.

The proposed model follows the script shown in Figure 3.3. The bioretention design input parameters are in blue, which include: return period, rain duration, contributing drainage area, soil properties, occupation scenario and filtration material medium (\% empty). The gray color shows the intermediate parameters, calculated by the model, as follows: rainfall intensity, rainfall, effective rainfall, runoff coefficient and peak flow. As the main system output, there is the cell volume, from which it will be sized and designed based on the available field area. In simulation module, used to verify the sizing (represented by the pink part in Figure 3.3), it is used PULS method, which has as outputs the hydrograph for: inflow, storage, outflow and percolation. These parameters, metrics and methods for computing them are explained in the following sections.

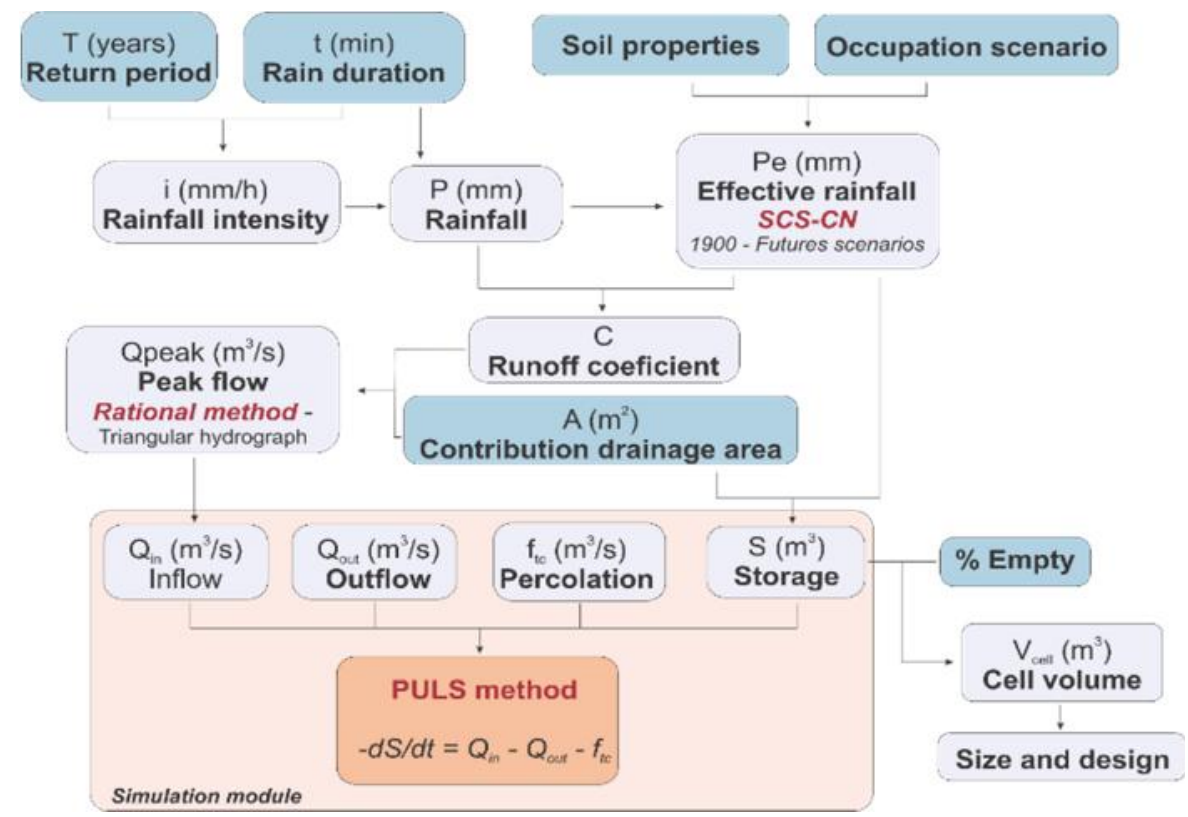

Figure 3.3 - Diagram used for modeling and computational simulation. The model input parameters are in blue. The pink part is the simulation module. The methods used in the intermediate and output variables calculus are in red color. 


\subsubsection{Hydrological risk and return period}

The risk adopted for designing stormwater management systems is defined as the probability of occurrence or when overcoming a considered critical event for a given return period (T). On risk analysis, it is implied that events have their origin in natural phenomena and that there are statistical hypotheses related to the processing of hydrological variables as being random. In this case, if $\mathrm{P}(\mathrm{X} \geq \mathrm{x})$ is the probability of an $\mathrm{X} \geq \mathrm{x}$ event, then the probability of $\mathrm{R}$ (hydrological risk) that $\mathrm{X} \geq \mathrm{x}$ occurs at least once in $n$ years is given by Eq. 3.17. Knowing that Eq. $3.18(\mathrm{~T})$ gives the return period, the hydrological risk can be written as in Eq. 3.19.

$R=1-[1-P(X \geq x)]$

$T=\frac{1}{P(X \geq x)}$

$R=1-\left\lfloor 1-\frac{1}{T}\right\rfloor^{n}$

According to this definition, it is known that the smaller the hydrological risk is, the higher is the return period. The adoption of a higher return period implies to size a device for increased flow, i.e., the structure will have higher cost. Considering the lack of resources, the choice of return period is economically limited.

\subsubsection{Soil properties}

Determining the soil type and hydrologic group is important to set the runoff division. In this model, the curve number method was chosen, identifying the $\mathrm{CN}$ coefficient according to Drainage Manual and Stormwater Management (São Paulo, 2012). The coefficient is, then, applied in the Natural Resources Conservation Service/Soil Conservation Service - NRCS/SCS hydrologic method (USDA, 1986) to determine the runoff. Another important soil property is the permeability coefficient, in order to quantify the percolation over time.

\subsubsection{Contribution of a drainage area and occupation scenario}

The contribution of a drainage area is determined to quantify the peak flow runoff and total rainfall volume. In urban areas, there is a great difficulty in defining the contribution 
area due to lack of alignment between the drainage projects and their implementation, as well as the large number of illegal foreign contributions.

It must also be determined the current land use area and occupation, as well as for future planning scenarios. Future scenarios should be determined in accordance with the guidelines of the local master plan.

\subsubsection{Rainfall intensity and total rainfall}

To calculate rainfall intensity the model uses the IDF equation (Eq. 3.20) with the coefficients $\mathrm{a}, \mathrm{b}, \mathrm{n}$ and $\mathrm{m}$ to the desired location. Then, we calculated total rainfall using the rainfall intensity (i) and the duration of the rain (t), according to Eq. 3.21.

$i=\frac{a \cdot T^{n}}{(t+b)^{m}}$

$P=i . t$

Eq. 3.21

\subsubsection{Effective rainfall}

Effective rainfall is calculated by the method of the Soil Conservation Service (SCS$\mathrm{CN}$ ) represented by Eq. 3.22 and 3.23.

$$
\begin{aligned}
& \text { Ii } P>0.2 S \rightarrow P=\frac{(P-0.2 S)^{2}}{P+0.8 S} ; I i P \leq 0.2 S \rightarrow P=0 \\
& S=\frac{2}{C}-254
\end{aligned}
$$

Where: Pe corresponds to effective rainfall; $\mathrm{P}$ to rainfall; and $\mathrm{S}$ to ground potential retention.

The $\mathrm{CN}$ coefficient represents the soil ability to retain runoff, ranging according to land use and occupation and soil type. Their values are tabulated (Drainage Manual and Water Management Stormwater - Stormwater Drainage Manual and Management, 2012), and use, as input, the soil hydrologic group and its use and occupation. If the area has more than a soil group and more than one use and occupation, the $\mathrm{CN}$ average value is then computed by means of Eq. 3.24.

$$
C=\frac{\sum A \cdot C}{\sum A}
$$

Where: Ai corresponds to the area of $\mathrm{i}$-th basin portion corresponding to $\mathrm{CN}_{\mathrm{i}}$ coefficient. 


\subsubsection{Runoff coefficient}

The use of rational method for the peak flow forecast requires determining the runoff coefficient $\mathrm{C}$. It represents the runoff generation percentage for the contribution area. The calculation was done according to Eq. 3.25 (KAWATOKO, 2012).

$C=\frac{P}{P}$

Eq. 3.25

\subsubsection{Peak flow}

For bioretention basins application as stormwater treatment practices, it is recommended small areas of contribution and microdrainage scale. Thus, it is considered the basins as small ones, when they are smaller than $3 \mathrm{~km}^{2}$, following the recommendations of the Stormwater Management Drainage Manual of São Paulo, and it is used the rational method (Eq. 3.26) to calculate the peak flow ( $\left.Q_{\text {peak }}\right)$.

$Q_{p} \quad=$ C.i.A

Eq. 3.26

\subsubsection{Inflow, outflow, percolation and storage}

One can make the inflow determination through rational triangular hydrograph method, taking as input to its construction the peak flow previously calculated and the basin concentration time. As the basin has small dimensions, it is reasonable to assume that the rain duration is equal to the basin concentration time. Thus, the hydrogram is represented as an isosceles triangle.

For the outflow, it was proposed a triangular weir with a $90^{\circ}$ opening angle. Thus, the flow rate is calculated by the Thomson equation (Eq. 3.27) as a function of water height (h) above vertex of the weir.

$Q_{o}=1.4 \cdot h^{2.5}$

Percolation flow is compounded by the percolation on the structure base and walls (Eq. 3.28). The flow is calculated based on the Green-Ampt and Darcy method (Eq. 3.29) (ERICKSON et al., 2013). 
$f_{T}=f_{b} \quad+f_{l l}$

Eq. 3.28

$f_{b} \quad=K \cdot A_{b} \quad \cdot\left(\frac{\psi+L+h}{L}\right)$

In which: $\mathrm{f}_{\text {base }}$ is percolation flow in the base; $\mathrm{f}_{\text {lateal }}$ is percolation flow in the walls; $\mathrm{K}$ is hydraulic conductivity; $A_{\text {base }}$ is the structure base area; $\Psi$ is wetting front suction; $\mathrm{L}$ is the saturated area length; and $\mathrm{h}$ is water level height above the base device.

Considering the saturated soil, the hydraulic unit gradient can be obtained in literature (Souza, 2002). Thus, it is possible to calculate the percolation on the sidewalls using Eq. 3.30. The total area of the sidewalls, as a function of time (t), is calculated through Eq. 3.31 .

$f_{l,} \quad=K \cdot \nabla \phi \cdot A_{l l}$

$A_{l l} \quad(t)=2 .(L+W+2 \cdot h(t))$

Where: $\mathrm{A}_{\text {lateral }}(\mathrm{t})$ is the sidewalls area and $\mathrm{h}(\mathrm{t})$ is the height of the water depth.

The purpose of the LID device in this project is to mitigate the effects of urbanization so that the effective rainfall is equal to, or less than, the prior urbanization situation, i.e. the situation described in the year 1900. According to Tucci et al. (1993), the dimensioning of intensive measures for flood control of hydraulic structures, such as reservoirs, is made to operate the reservoir in such a way to dispose the natural flow until it damps the peak flow and it is transferred downstream. In Tucci et al. (1995), simplified methods to scale flood control structures in holding a tank are presented and they use only a few input hydrograph information such as the value of peak, peak time and/or time of concentration. Considering these elements and establishing a critical flow output, which is less than or equal to the natural flow of the river, it is estimated the volume of the required reservoir. Thus, in this case, the storage $(\mathrm{S})$ is calculated using the difference in depth minus the peaks, according to Eq. 3.32.

$S=\frac{P_{i}-P p u}{1} . A$

Eq. 3.32

The bioretention cell is filled with a granular material. By knowing the medium material porosity, the estimated volume of the compensatory structure is calculated using Eq. 3.33 .

$V_{c}=\frac{1 . S}{n}$

Where: $\mathrm{n}$ is media material porosity. 
The PULS method is also known as the "Level Pool Routing" and it is used to simulate retention device-behavior. It considers the continuous equation, described in Eq. 3.34 (CHOW et al., 1998). Adjusting to a bioretention cell inputs and outputs, we obtain the Eq. 3.35 , which describes output mainly as a function of the percolation and outflow spillway geometry. Dividing the flood hydrograph propagation into discrete intervals of width $t$, the continuity equation is integrated during each interval, providing the retained volume in the device. In this paper, we used the tabular method with automation in BIRENICE.

$\frac{\partial}{\partial}+\frac{\partial}{\partial}=0$

$\frac{\Delta S_{t}}{\Delta t}=\overline{I_{t}}-\overline{O_{t}}-\overline{f_{T, t}}$

Where: $S_{t}$ is storage volume; $I_{t}$ represents inputs (runoff $\left(Q_{i n}\right)$ and rainfall directly in the bioretention cell); $\mathrm{O}_{\mathrm{t}}$ represents the outputs corresponding to the outflow ( $\left.\mathrm{Q}_{\text {out }}\right)$; and $\mathrm{f}_{\mathrm{TC}, \mathrm{t}}$ corresponds to soil percolation.

Applying the previously described parameters, each bioretention cell should be sized to meet specific runoff reduction and retention goals. Any considerations should be based upon its individual layout.

\subsection{Case Study - Field Application}

\subsubsection{Study site}

The field application of the proposed simulation method was made for a micro drainage system located at Campus - Area 2 of University of São Paulo, located in São Carlos, SP, Brazil (Figure 3.4). The study area is located in the sub-basin that belongs to São Carlos's urban basin, but with different soil occupancy levels, since it is located on a stillexpanding campus. Figure 3.5 shows contribution area layout, indicating the paths that contribute to runoff. The sub-basin has a total area of 2,3 ha. 


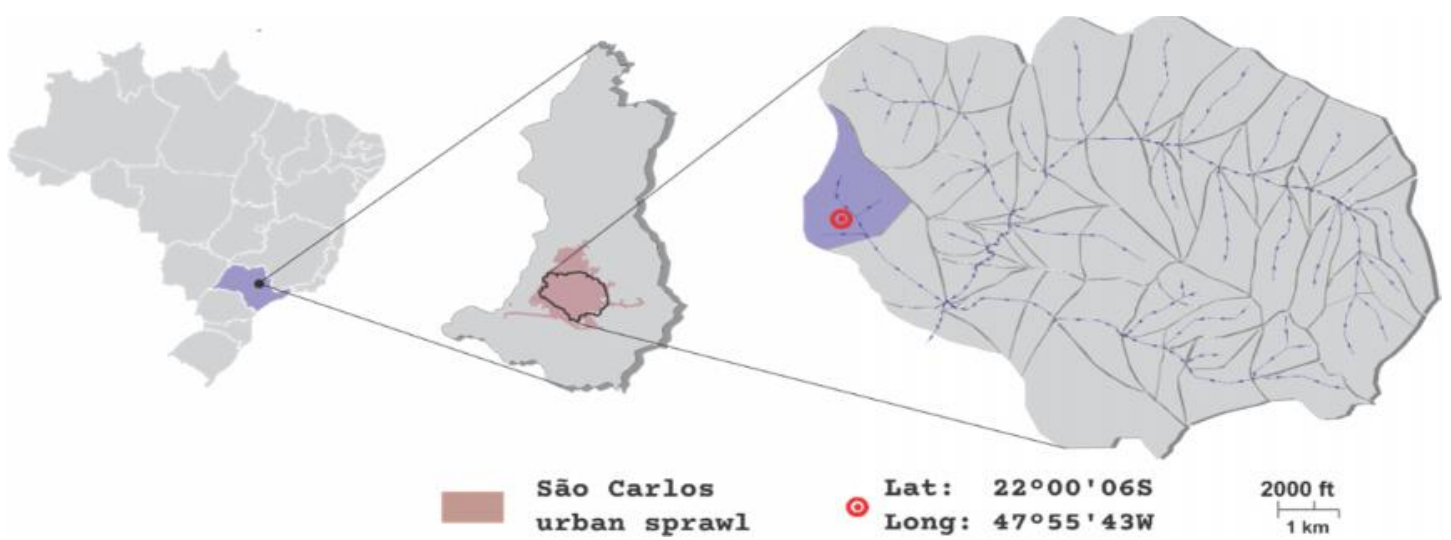

Figure 3.4 - Application field of experimental bioretention system - the red point represents its location in the Mineirinho sub-basin, which comprises São Carlos urban basin.

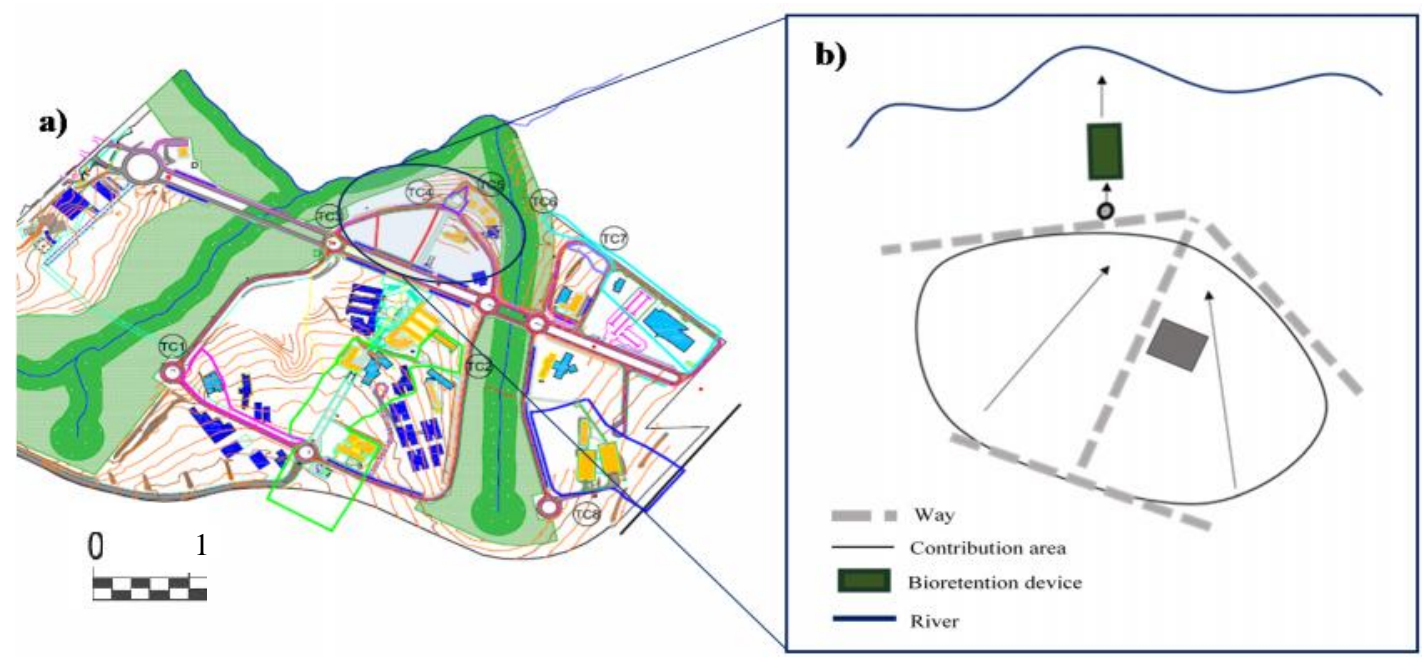

Figure 3.5 - Bioretention implementation area - a) Map of the Campus - Area 2 of USP- São Carlos, containing all eight basins proposed for a bioretention technique installation; b) Contribution area scheme

Scenarios were developed projecting the size of the campus at pre development (year 1900), current (year 2013) and future (year 2025); the existent bioretention cell was incrementally expanded.

Overall, the retention catchments are sized based on a quota limit, which aims to the volume that is reached when critical flow occurs. In the case of bioretention cell, it also scales to a critical flow to be transferred to the receiving body. However, in this case, as the goal is to restore pre-settlement patterns to avoid impacts on the adopted downstream critical flow, it is that which of them had for the natural environment. For this case study, the 1900 scenario represents the natural environment.

Otherwise, the site of application is in the expansion process and is not fully occupied, according to his master plan. Thus, it is important to establish scenarios to assess how the progressive increase in the land use and occupation impact the runoff production. Considering this forecast, the method developed also scales future modular expansions to meet increased demands due to changes in land use. 


\subsubsection{Determination of model parameters}

\section{Hydrological Risk and Return Period}

According to the Drainage Manual and Stormwater Management (São Paulo, 2012) for microdrainage, it is recommended to use return period values ranging between 2 to 10 years. Tucci et al. (1993) and Tucci et al. (1995) also recommend that, for micro drainage articles, time ranging used stays between 2 to 10 yeas. Considering the Brazilian situation and its financial constraints, long-term investments t imply high construction costs. Thus, Tucci et al. (1993) recommends different values of $\operatorname{Tr}$ for various occupations and, for occupancy by public buildings, it is recommended the value of 5 years. Thus, it was selected a value of 5 years, representing medium hydrological risk. The hydrological risk was calculated based on Eq. 3.36.

$R=1-\left[1-\frac{1}{T}\right]^{n}$

\section{Rainfall intensity}

Using the IDF curve (Eq. 3.20), parameters proposed by Barbassa (1991) for the city of São Carlos, it was possible to calculate rainfall intensity relative to the application field. In Eq. 3.36, $i(\mathrm{~mm} / \mathrm{h})$ represents rainfall intensity; $T$ (years) is return period; and $t(\mathrm{~min})$ is rain duration.

$i=\frac{1519 \cdot T^{0,2}}{\left(t+16^{0,9}\right)}$

\section{Rain duration}

To estimate total precipitation, departing from rainfall intensity, it was used a 20minute rainfall duration. To select the time of precipitation, the precipitation intensity variations were studied as a function of time $t$ of precipitation and the return time $\operatorname{Tr}$ by varying them. It was observed that from the time $\mathrm{t} 25 \mathrm{~min}$, the precipitation intensity curves for different $\operatorname{Tr}$ are almost coincident. As Barbassa (1991) noted, the more frequent rain time in the city of São Carlos is 20 min. 


\section{Contributing drainage area and occupation scenarios}

We delineated the contributing drainage areas using an updated version of Campus Area 2 map and field visits - some during rain period, for better observation of the contribution of the sub-basins and its limits. We also manually completed the delineations using AutoCAD 2010. The contribution area has a total of 2.3ha.

The updated map of Campus - Area 2 also comprises existing buildings, the buildings in construction and those approved for construction in the near future. Given the obvious lack of information corresponding to the completion of construction, all of these areas were considered as complete in 2013. Additionally, the map shows the Permanent Preservation Areas (APP), a strict conservation area, which comprises, among others, riverbanks, to some extent proportional to the river width. The non-occupied areas and those outside the APPs were classified as pasture, due to the vegetation in the area, once it is undergrowth and predominantly Brachiaria sp. According to the campus master plan, the future occupation scenario was assumed to be at $50 \%$ in $2025,75 \%$ in 2050 and $85 \%$ in 2100 . To simulate the past scenario, setting the year 1900 as reference, the entire area was assumed to consist of native forest.

\section{Soil properties}

The determination of the soil type was based on particle size analysis. According to the distribution curve of ground particle size, the soil belongs to group C - loamy soils with total clay content of $20 \%$ to $30 \%$ - but with no impervious clay layer or containing rocks at depths up to $1.2 \mathrm{~m}$. For forested areas, it was forests in poor condition, with $\mathrm{CN} 77$. The occupied areas were considered industrial districts ( $72 \%$ waterproofing) with $\mathrm{CN} 91$. For the pasture areas, it was adopted CN 79, pasture in average conditions. For APP, there were adopted CN 73, forest in good condition in 2013, and in the years 2025, 2050 and 2100, forest on bad terms with CN 77.

Infiltration tests were also carried out in the original soil of the area, for further identification of flow percolation. As results, the hydraulic conductivity coefficient was $1.62 \times 10^{-4} \mathrm{~cm} . \mathrm{s}^{-1}$, which classified the soil as low permeability. 


\section{Filtration media material}

As filtering material it was selected a composition of a $0.70 \mathrm{~m}$ gravel layer and a $2 \mathrm{~m}$ sand layer. These materials have the respective $45 \%$ and $30 \%$ as $\%$ empty.

\subsubsection{HEC-HMS simulation}

In order to verify the applicability for the proposed method, we compared it with another numerical model, Hydrologic Modeling System (HEC-HMS 3.5) (USACE, 2010). HEC-HMS is a rainfall-runoff model, which allows simulations in concentrated or semidistributed forms. It has been successfully used in impacts caused by climate change and land use change in small basins studies (MEENU, et al., 2012; SAMIRAN, et al., 2012; SIMONOVIC, 2010; McENROE, 2010; CUNDERLIK, 2005).

For the simulation with HEC-HMS, the study used the curve number method in order to determine effective rainfall and peak flow. The same two scenarios were adopted: with land use in 1900 as a period of unchanged vegetation and the altered (urbanized) scenario projected to 2013 - 2025, both represented by the change in $\mathrm{CN}$ values in each simulation.

We also propose the evaluation of the catchment's response to a 20-minute rainfall event of 10-year return period, same parameters as BIRENICE. For the simulation, we assumed a short-term water balance in order to estimate the bioretention cell's size. In the HEC-HMS structure, a reservoir represents the bioretention cell at the output, composed by a triangular spillway. The useful volume of the cell is adopted as the soil empty ratio. A stagevolume curve characterizes the cell's geometry. In this case, the calculation of hydrograms is made using the unit hydrogram method and, to quantify the storage and discharge variation, it is used the Muskingum method.

\subsection{Results and Discussion}

\subsubsection{BIRENICE sizing}

The model was structured to be used with multiple scenarios as opposed to building a single structure to meet a final plan (in 2100). Table 3.2 shows the main results of BIRENICE method (Calculation memorial is attached at the end of this chapter). From the construction area availability and storage and cell volume calculated, it was determined the practice dimensions. Initially, only the first module is built, which will meet the first stage (20132025). In 2025, to attend the urbanization expansion, the second module will be recalculated 
and built as an expansion of the first one, which will attend the second stage (2025-2050). Then, in 2050, the same process will be conducted and the third module will be constructed, which will meet the third stage (2050-2100).

The structure should be built from upstream to downstream, so that the input structure can be used in all stages, avoiding rebuilding. The area required for the final plan (2100) has been put apart since the beginning. Figure 3.6 depicts the scheme by which the bioretention dimensions are incrementally in expansion with each interaction, sized by the methodology described in this paper. In short, for 2025, the first module dimensions are: 12.99 (height) x 5.6 (width) x 3.2 (depth) $\mathrm{m}$. The highlighted area in red shows the modular expansion planned. Parameters considered to size all bioretention cell modules and its final dimensions are in Table 3.2.

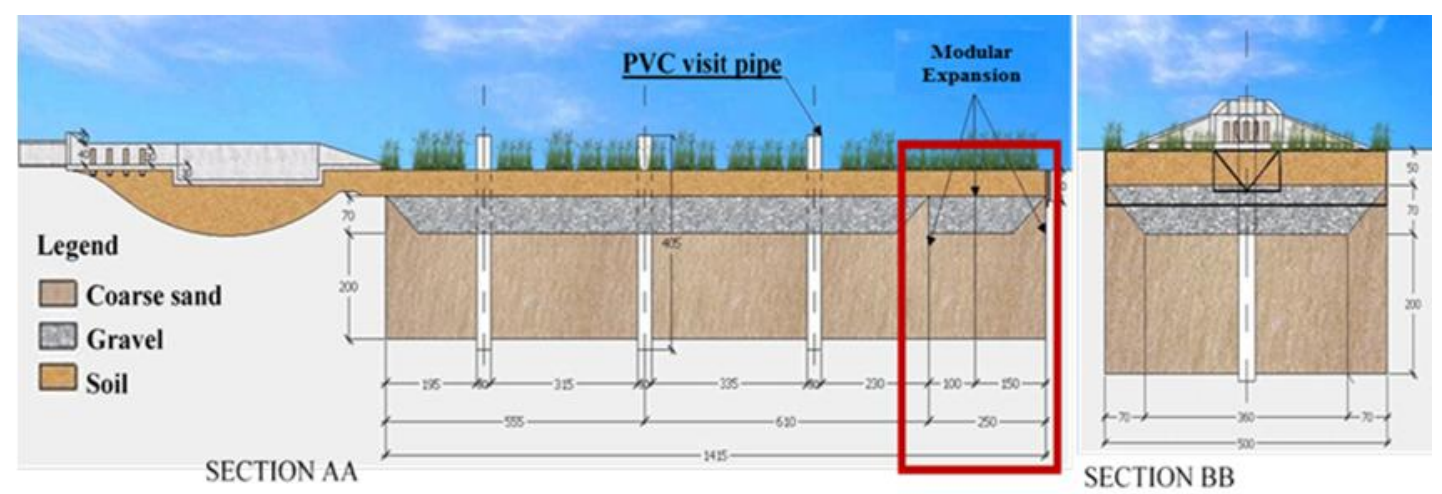

Figure 3.6 - Bioretention dimensions considering modular expansion (in red).

\begin{tabular}{|c|c|c|c|c|}
\hline & 1900 & 2025 & 2050 & 2100 \\
\hline $\mathrm{CN}$ & & 85 & 88 & 89.2 \\
\hline Impervious area (\%) & & $50 \%$ & $75 \%$ & $85 \%$ \\
\hline $\mathrm{T}$ (years) & & 5 & 5 & 5 \\
\hline $\mathrm{t}$ (minutes) & & 20 & 20 & 20 \\
\hline $\mathrm{i}(\mathrm{mm} / \mathrm{h})$ & & 91.7 & 91.7 & 91.7 \\
\hline $\mathrm{P}(\mathrm{mm})$ & & 26 & 26 & 26 \\
\hline Peak Flow* $\left(\mathrm{m}^{3} / \mathrm{s} / \mathrm{mm}\right)$ & 0.027 & $0.092 / 1.34$ & $0.133 / 1.19$ & $0.153 / 1.15$ \\
\hline Storage $\left(\mathrm{m}^{3}\right)$ & & 78.9 & 128.2 & 152.2 \\
\hline Vcell $\left(\mathrm{m}^{3}\right)$ & & 232.9 & 378.3 & 449.0 \\
\hline Length (m) & & 12.99 & 21.11 & 25.05 \\
\hline Width (m) & & 5.60 & 5.60 & 5.60 \\
\hline Depth (total) (m) & & 3.20 & 3.20 & 3.20 \\
\hline
\end{tabular}

Table 3.2 - Bioretention cell modular sizing for application field

To confirm the sizing obtained, a simulation module was used. The results are presented in Figure 3.7 for the year 2025 (first module - bioretention area of $72.74 \mathrm{~m}^{2}$ ) (Figure 
3.7a), 2050 (second module - bioretention area of $118.22 \mathrm{~m}^{2}$ ) (Figure 3.7b) and 2100 (third module- bioretention area of $140.28 \mathrm{~m}^{2}$ ) (Figure 3.7c). It has been noted an increasing runoff for future scenarios (with increased urbanization) resulting consequently in an increase in storage and bioretention cell volume (Table 3.3).

As for storage, we have observed that the structure reaches its peak around $30 \mathrm{~min}$ for all scenarios, at the time the outflow starts. The results of simulation module display a reduction in the peak flow to none and total volume transferred to downstream, accomplishing one of the goals of using LID practices. It also states that the transferred volume difference is stored in the soil and percolates through the ground, replenishing the groundwater. Therefore, there is a water balance closest to pre-urbanization scenario.

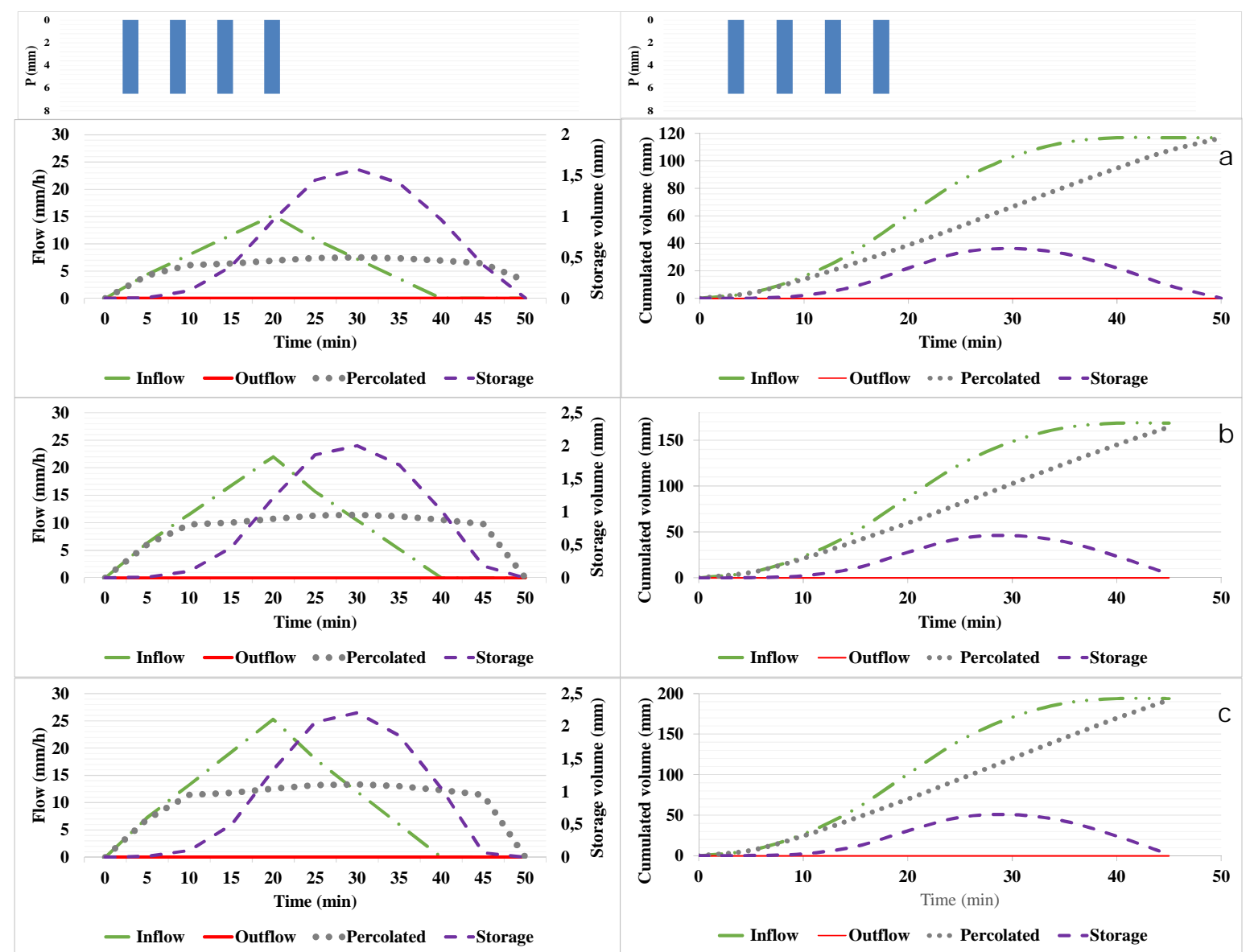

Figure 3.7 - Internal water dynamics hydrographs and cumulative volumes obtained with BIRENICE simulation for (a) 2025, (b) 2050 and (c) 2100 .

Modular sizing conserves limited financial resources and more closely follows future needs. Resources are finite; so building a smaller structure leads to a cost reduction; consequently, so the saved capital can be spent on other projects. This hedges risk, as the predictions of future conditions at the campus are by nature uncertain, thus the structure is sized for immediate needs during each scenario. Predictions can be as close to reality as closer they are performed, thus, a three-step sizing was done. In the future, before the following 
modules are constructed, new designs and associated sizing will have evaluated with the model using updated (and hence more accurate) input data.

\subsubsection{BIRENICE AND HEC-HMS simulations}

To simulate and compare with BIRENICE and HEC-HMS methods, the return period of 5 years and 20-minute rainfall duration were selected as input data. The rainfall intensity was then calculated, giving a value of $77.87 \mathrm{~mm} / \mathrm{h}$. The comparative results for the year 1900 (pre urbanization) and 2025 (first stage) will be presented in this section.

The comparison between BIRENICE and HEC-HMS was done for the years 1900 (pre-urbanization) and 2025 (corresponding to the first module, therefore, the field implantation for monitoring).

We first determined input hydrographs for the corresponding bioretention cell catchment area. Figure 3.8 shows the results obtained with both methods for the years 1900 (pre-urbanization) (Figure 3.8a) and 2025 (Figure 3.8b). It can be noted that, for both scenarios, the peak flow occur 20 min after the rainfall starts, for BIRENICE and HEC-HMS. However, there is a little difference in hydrograph shape and peak. This difference is associated with the different methods used by the two models. Once BIRENICE uses the rational method triangular hydrograph; HEC-HMS uses the SCS-CN with the unit hydrograph. Moreover, BIRENICE estimates greater peak flows than HEC-HMS; (Table 3.3). The difference between the peak flows of the two methods is lower for a greater level of urbanization (2025), presenting a percentage difference of $6 \%$.

\begin{tabular}{lcc}
\hline & $\mathbf{1 9 0 0}$ & $\mathbf{2 0 2 5}$ \\
\hline BIRENICE $(\mathrm{mm} / \mathrm{h})$ & 4824 & 1296 \\
$\operatorname{HEC}(\mathrm{mm} / \mathrm{h})$ & 4536 & 900 \\
$\operatorname{Dif}(\mathrm{mm} / \mathrm{h})$ & 288 & 396 \\
$\operatorname{Dif}(\%)$ & $6 \%$ & $30 \%$ \\
\hline \multicolumn{2}{c}{ Table 3.3 - Peak flow comparison between BIRENICE and HEC-HMS method }
\end{tabular}

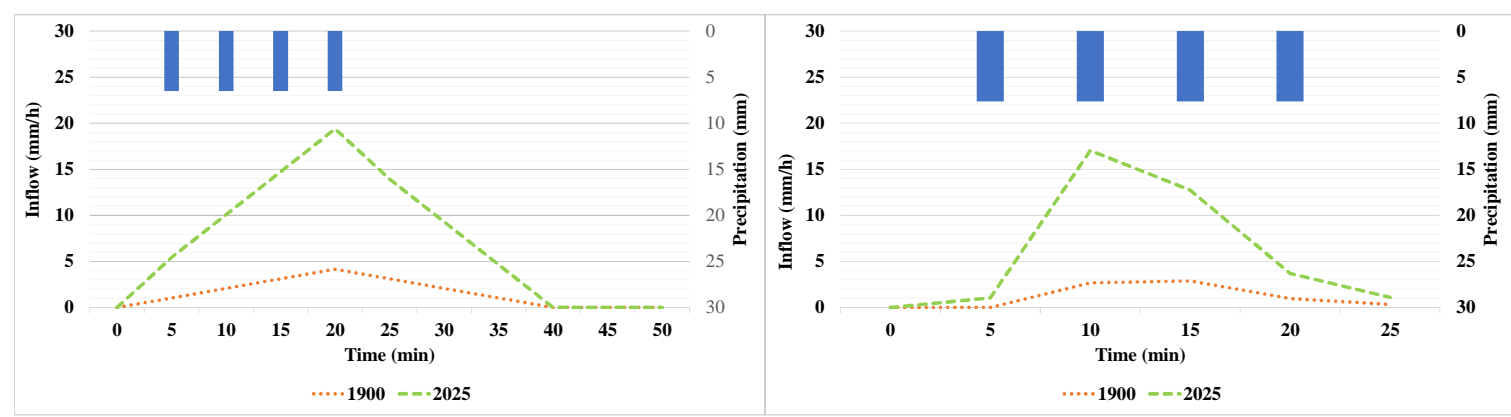

Figure 3.8 - Comparative inlet hydrographs between BIRENICE (a) and HEC-HMS (b) for 1900 and 2025 
The inflow hydrograph obtained through BIRENICE method was used as input data to size the bioretention cell, as shown in the previous section. BIRENICE and HEC-HMS also simulate the internal water dynamics in the basin for 2025 (Figure 3.9).

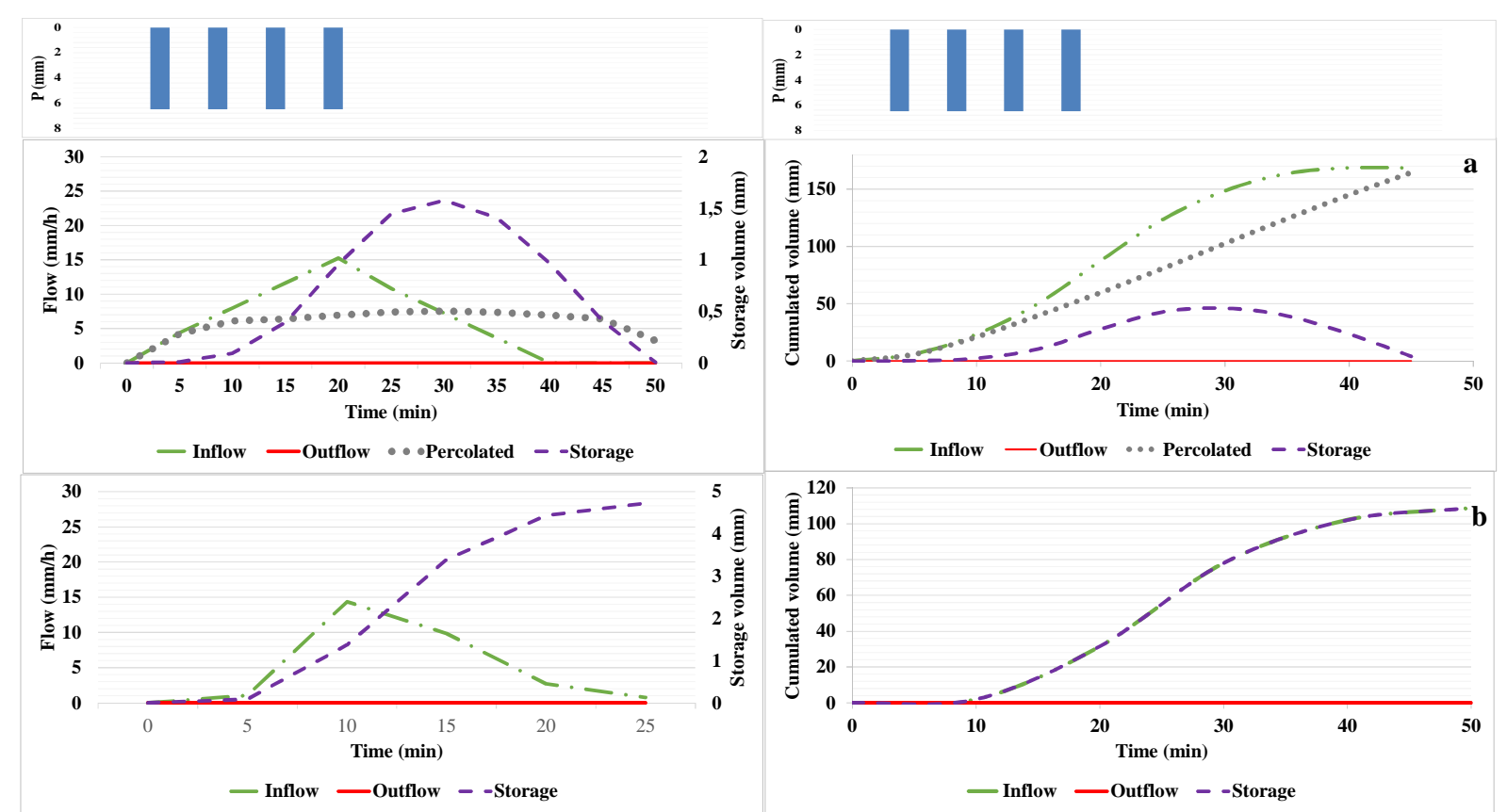

Figure 3.9 - Internal water dynamics simulation and cumulative volumes for 2025 with methods (a) BIRENICE and (b) HEC-HMS

For the volume stored in the basin, in 2025, the BIRENICE method gives a storage peak in $30 \mathrm{~min}$ (10 min after the peak flow from inlet hydrograph), presenting a volume value around $500 \mathrm{~mm}$ (Figure 3.9a). After the peak, the storage decreases quickly and continuous due to the percolation process. On other hand, for HEC-HMS method the storage peak volume is around $1500 \mathrm{~mm}$ and occurs in $50 \mathrm{~min}(30 \mathrm{~min}$ after the peak flow from inlet hydrograph) (Figure 3.9b). The simulations have a difference in the order of $70 \%$ as the basin storage capacity, for both scenarios, being the most significant difference between the two methods. To explain this difference, it should be noted that the HEC-HMS does not have a specific option for LID practices, thus simulating the bioretention cell was done through an adaptation in a reservoir simulation. In this program function, it is not possible to insert percolation losses directly in the ground, so it was not considered. Therefore, in Figure 3.9b the storage reaches its peak and remains constant, as for BIRENICE it is noted the decrease in time and less important storage peak, once the percolation represents a water loss.

To value the behavior storm of the bioretention technique, the calculations of the hydric concentration were done and the results were introduced in Table 3.4 . Note that both BIRENICE and HEC show no outflow during the event. It could have occurred, for example, 
that there was $100 \%$ of water retention efficiency for the simulated scenarios. You can also note that for BIRENICE, despite having a peak of expressive flow, the runoff that enters the technique fully percolates, helping to restore the water balance of pre-urbanization. The HEC, in turn, does the forecast percolated volume. It is estimated that all the runoff is stored in bioretention basin, leading to the storage's highest peak.

\begin{tabular}{lcccccc}
\hline & & \multicolumn{4}{c}{ Equivalent depth $(\mathrm{mm})$} \\
\cline { 3 - 7 } & & Precipitation & Inflow & Outflow & Percolated & Storage peak \\
\hline \multirow{3}{*}{ BIRENICE } & 2025 & & 5.1 & 0 & 5.1 & 1.6 \\
& 2050 & 26 & 7.3 & 0 & 7.3 & 2.0 \\
& 2100 & & 8.4 & 0 & 8.4 & 2.2 \\
\hline \multirow{2}{*}{ HEC-HMS } & 2025 & 26 & 4.8 & 0 & - & 4.8 \\
\hline \multicolumn{5}{c}{} \\
\cline { 3 - 6 }
\end{tabular}

With this comparison, it is clear that the differences in simulations for both methods are small, which corroborates for using the developed method (BIRENICE) for future applications, since it is targeted to bioretention basin. However, the study recommends further comparison of its simulation with data obtained by monitoring the practice in the field for actual method confirmation.

\subsubsection{Comparison between to the sizing methods described}

The BIRENICE method was executed based on the effective precipitation difference projected in a year and standing urbanization period for peak flow retention. The simulation showed that the module design is efficient so that the entire volume of accumulated rain is retained in a bioretention bowl. This result can be confirmed by the simulation performed on HEC-HMS, confirming the applicability of the method.

It performed a comparative evaluation between the scaling performed by the proposed method (BIRENICE) with the methods presented by Silveira \& Goldenfun (2007), Sizing by runoff retention by Akan \& Houghtalen (2003) Sizing by pollutant charge retention and (McAuley, 2009) Sizing by bioretention. The results are shown in Table 3.4, which are matched dimensions and volumes obtained from each useful as a storage volume. It is possible to observe the runoff sizing methods by the size and retention of the bioretention, which resulted in volumes up to 500\% higher than for BIRENICE, as pollution by the sizing method resulted in retention volume close to that BIRENICE. 


\begin{tabular}{|c|c|c|c|c|c|c|c|c|}
\hline Method & Equation & Reference & $\mathrm{L}(\mathrm{m})$ & $\mathrm{B}(\mathrm{m})$ & $\mathrm{h}(\mathrm{m})$ & Vutil $\left(\mathrm{m}^{3}\right)$ & $\begin{array}{c}\text { Vutil/ } \\
\text { Vutilbirenice } \\
(\%)\end{array}$ & $\begin{array}{c}\text { Efficiency } \\
(\%)\end{array}$ \\
\hline $\begin{array}{l}\text { Sizing by } \\
\text { runoff } \\
\text { retention }\end{array}$ & Eq 3.1 to 3.4 & $\begin{array}{l}\text { Silveira \& } \\
\text { Goldenfun } \\
\text { (2007). }\end{array}$ & 29 & 10 & 1,4 & 406,8 & -473 & 97 \\
\hline $\begin{array}{l}\text { Sizing by } \\
\text { pollutant } \\
\text { charge } \\
\text { retention }\end{array}$ & Eq 3.5 to 3.9 & $\begin{array}{l}\text { Akan \& } \\
\text { Houghtalen } \\
(2003) \text { and } \\
\text { Hatt et al. } \\
(2009)\end{array}$ & 10 & 6 & 1,4 & 79,5 & +92 & 88 \\
\hline $\begin{array}{l}\text { Sizing by } \\
\text { bioretention } \\
\text { device }\end{array}$ & $\begin{array}{c}\text { Eq } 3.10 \text { to } \\
3.13\end{array}$ & $\begin{array}{l}\text { McAuley } \\
\text { (2009) }\end{array}$ & 29,5 & 10 & 1,4 & 412 & -479 & 55 \\
\hline BIRENICE & & & 12 & 5,6 & 3,2 & 86 & - & 100 \\
\hline
\end{tabular}

Table 3.5 - Comparative results of sizing methods (see equations and criteria in the text)

In Table 3.5, it is possible to analyze the calculated efficiencies presented for each method, using the empirical data presented about the area and compare it with the BIRENICE method. For Sizing method by runoff retention, it was reached an efficiency of $97 \%$ retention of runoff volume. The Sizing methods by pollutant retention and Sizing charge by device bioretention have an efficiency of $88 \%$ and $55 \%$ respectively. It is noteworthy that for these two methods, the efficiency was considered only for parameter SS of solids.

Note that the useful volume calculated is quite different, which would entail the construction of a system with different relations and dimensions. So, the research considered the specific area to be built as well, proposing an easily applicable system, which does not demand large investments in infrastructure and is easy to perform and understand. It was built a system which has advantages regarding to the qualitative treatment, using a pre-treatment primarily to retain sediment and solids. It is also considered a deeper system than the conventional one, with a significant filter layer, which, consequently, increases the area storage.

Despite the significant difference, simulations made by BIRENICE and HEC-HMS showed that the dimensions obtained are able to retain all the flow. All in all, these other methods have a greater number of variables and, sometimes, it is difficult to determine (such as $b$ the Akan method) the results, becoming complex to implement. The large volume estimated by these methods also makes deployment costs higher.

Compensatory techniques are implemented and disseminated as part of public policies in countries with financial constraints. Thus, it is necessary that its design method be simpler to use and with lower deployment costs, especially when compared to conventional systems. Considering this, the BIRENICE method, which uses the difference of effective rainfall, meets these needs and limitations when compared to other methods, without losing efficiency. 


\subsection{Conclusion}

The objective of this research was to propose a design method for a bioretention cell that addresses system sizing and uses a computational model to perform evaluation. This method is proposed as an alternative technology for improving the performance of urban drainage systems. The case study was conducted in a drainage area located at Campus - Area 2 of USP São Carlos.

The bioretention cell designed for this basin was sized for a 5-year return period, seeking to attenuate peak flow and to reduce runoff volume. A 20-minute rainfall was used in BIRENICE method and the eventual bioretention cell was sized in a way that no overflows would occur during the next 5 years. Device storage peak occurs shortly after the hydrograph runoff peak and the structure emptying time is around 50 minutes for all scenarios. The outflow passing through the spillway, in all cases, is null. It represents an output hydrograph temporal rearrangement, because of the bioretention device. The comparison to the HECHMS method was used to validate the results obtained by the computational model.

We conclude that:

- $\quad$ The sizing and simulation method proposed, BIRENICE, has little difference with HEC-HMS results. Therefore, it is an efficient method and recommended for further research of the presented topic.

- $\quad$ BIRENICE method allows planned sizing for future expansion, called modular sizing. Thus, it also allows lower initial investment and appropriateness to the objective dimensions.

- Inside its simulation, it is included storage decay, through percolation process.

- It is easy to use the model, which was designed to subtropical areas, but also allows the user to customize the parameters for local needs.

\section{Acknowledgments}

The authors acknowledge the support of the projects: (1) MAPLU2 - Stormwater Management in Urban Environment/FINEP, (2) Thematic Project 2008/15161-1 FAPESP "Assessment of Impacts and Vulnerability to Climate Change in Brazil and Strategies for Adaptation Options" (3) Casadinho/PROCAD CNPq 552494/2011-9 (UFAL-EESC / USP) "Advanced monitoring of biotechnological processes and environmental quality" and (4) CNPq 307637/2012-3 of Scientific Productivity. 


\section{References}

AKAN, O \& HOUGHTALEN, R, 2003. Urban hydrology, Hydraulics \& Stormwater Quality: Engineering Application and Computer Modelling, Hoboken, J Wiley.

BAPTISTA, M.;CBARRAUD, S.; NASCIMENTO, N.O., 2005. Compensatory techniques in urban drainage. Porto alegre: Editora ABRH.

BARBASSA, A. P., 1991. Simulation of Urbanization Effect on Rain Drain the City of San Carlos), SP.Thesis (PhD in Hydraulics and Sanitation - USP, EESC, São Carlos).

CUNDERLIK, J., 2005. Simonovic, S. Hydrological extremes in a southwestern Ontario river basin under future climate conditions. Hydrological Science-Journal-des Science Hydrologiques, 50(4), 631-654. August.

CHOW, V.T., MAIDMENT, D.R., MAYS, L.W., 1988. Applied Hydrology. McGraw-Hill, Singapure.

CORDERO, W., 2012. Multi-objective oprimization for urban drainage rehabilitation. Thesis., TU-Delft \& UNESCO-IHE, Delft Netherlands.

DAVIS, A. P., HUNT, W. F., TRAVER, R. G., \& CLAR, M. 2009. Bioretention Technology: Overview of Current Practice and Future Needs. Journal of Environmental Engineering, 135(3), 109-117.

DIETZ, M.E. and J.C. CLAUSEN. 2008. Stormwater runoff and export changes with development in a traditional and low impact subdivision. J. Environ. Manage. 87: 560566. doi:http://dx.doi.org/10.1016/j.jenvman.2007.03.026.

ELLIOTT, A. H.; TROWSDALE, S. A., 2007. A review of models for low impact urban stormwater drainage. Environmental Modelling \& Software, v. 22, p. 394-405.

ERICKSON, A. J.; WEISS, P. T.; GULLIVER, J. S., 2013. Optimizing Stormwater Treatment Practices: A handbook of assessment and maintenance. Springer, New York.

FAIR, G.M.,GEYER, J.C., 1954. Water supply and waste-water disposal. John Wiley \& Sons, Inc., New York.

FLETCHER, T. D., et al. 2014. SUDS, LID, BMPs, WSUD and more - The evolution and application of Terminology surrounding urban drainage. Urban Water Journal.

HATT, B; FLETCHER, T.; DELETIC, A., 2009. Hydrologic and pollutant removal performance of stormwater biofiltration systems at the field scale. Journal of Hydrology, v. 365,n. 3-4, p. 310-321.

KAWATOKO, I. E. S., 2012. Establishing Scenarios of Structural and Non-Structural measures For Management of Urban Water Lot Scale. Master in Hydraulics and Sanitation - USP, EESC, São Carlos.

LEE, S., \& YIGITCANLAR, T., 2010. Sustainable urban stormwater management : water sensitive urban design perceptions, drivers and barriers. In T. Yigitcanlar (Ed.), Rethinking Sustainable Development: Urban Management, Engineering, and Design (pp. 1072-1083). Hershey: IGI Global.

LINTERN, A. et al., 2011. Key design characteristics that influence the performance of stormwater biofilters. In Proceedings of 12th International Conference on Urban Drainage, Porto Alegre/Brazil, 11-16 September.

LIU, J., D. SAMPLE, C. BELL and Guan, Y. 2014. Review and Research Needs of Bioretention Used for the Treatment of Urban Stormwater. Water 6: 1069-1099.

LUCAS, W. C., \& SAMPLE, D. J. (2015). Reducing combined sewer overflows by using outlet controls for Green Stormwater Infrastructure: Case study in Richmond, Virginia.

Journal of Hydrology, 520, 473-488. http://doi.org/10.1016/j.jhydrol.2014.10.029

McAUlEY, A., 2009. Technical Design Guidelines. Nothern Territpty Department of Planning and Infrasctructure. 
McENROE, B., 2010. Guidelines for Continuous Simulation of Streamflow in Johnson County, Kansas, with HEC-HMS. Report: Johnson County Public Works and Infrastructure Storm water Management Program.

MEENU, R. REHANA, S. MUJUMDAR, P., 2012. Assessment of hydrologic impacts of climate change in Tunga-Bhadra river basin, India with HEC-HMS and SDSM. HYDROLOGICAL PROCESSES. DOI: 10.1002/hyp.9220. Hydrol. Process.

PANAGOPOULOS, Y., MAKROPOULOS, C., \& MIMIKOU, M., 2013. Multi-objective optimization for diffuse pollution control at zero cost. Soil Use and Management.

PGC - PRINCE GEORGE'S COUNTY. Bioretention Manual. Department of Environmental Resources, Maryland. 206p. 2007.

PRINCE GEORGE'S COUNTY. 2000. Low-Impact Development Design Strategies, An Integrated Design Approach. Department of Environmental Resources, Programs and Planning Division, Largo, MD.

ROY-POIRIER, A.; CHAMPAGNE, P.; FILION, Y., 2010. Bioretention processes for phosphorus pollution control. Environ. Rev. 18, 159-173.

SAMIRAN, D. SIMONOVIC, S., 2012. Assessment of Uncertainty in Flood Flows under Climate Change Impacts in the Upper Thames River Basin, Canada. British Journal of Environment \& Climate Change 2(4): 318-338.

SAMPLE, D. J., GRIZZARD, T. J., SANSALONE, J., DAVIS, A. P., ROSEEN, R. M., \&

WALKER, J. (2012). Assessing performance of manufactured treatment devices for the removal of phosphorus from urban stormwater. Journal of Environmental Management, 113, 279-291. http://doi.org/10.1016/j.jenvman.2012.08.039

SAMPLE, D. J., \& LIU, J. (2014). Optimizing rainwater harvesting systems for the dual purposes of water supply and runoff capture. Journal of Cleaner Production, 75, 174194. http://doi.org/10.1016/j.jclepro.2014.03.075

SÃO PAULO (city). Municipal Department of Urban Development. Drainage Manual and Stormwater Management: management of urban drainage system. São Paulo: SMDU, 2012. <http://www.habisp.inf.br/>

SHARMA, A. K., et al. 2008. Assessing integrated water management options for urban developments: Canberra case study. Urban Water Journal, 5(2), 147-159.

SILVEIRA, A. L. L.; GOLDENFUM, J. A., 2007. Generalized Methodology for PreDimensioning of Rain Control Devices in the Source. Brazilian Journal of Water Resources, v. 12, n. 2, p. 157-168.

SIMONOVIC, S., 2010. A new methodology for the assessment of climate change affects a watershed scale. Climate change and water resources. Vol. 98, No 8, 1047-1045.

SOUZA, C. F.; CRUZ, M.A.S.; TUCCI, C.E.M., 2011. Adapting a rainfall-runoff model to simulate LID stormwater systems. In:Proceedings of 12th International Conference on Urban Drainage, POA/Brazil, 11-16 September.

TUCCI, C. E. M.; da SILVEIRA, A. L. L.; [et al.]. Hydrology: Science and Application . 4 ed, ABRH, Porto Alegre, 1993.

TUCCI, C. E. M.; PORTO, R. L. L.; de BASTOS, M. T. Urban Drainage. 1 ed, ABRH, Porto Alegre, 1995.

USDA (U.S. Department of Agriculture). 1986. Urban Hydrology for Small Watersheds (TR55). United States Department of Agriculture, Natural Resources Conservation Service, Conservation Engineering Division, Washington D.C.

WINSTON, R. J.; LUELL, S. K.; HUNT, W. F., 2011. Evaluation of Undersized Bioretention for Treatment of Highway Bridge Deck Runoff. In Proceedings 12th International Conference on Urban Drainage, Porto Alegre, Brazil.

ZHOU, Q., 2014. A review of sustainable urban drainage systems considering the climate change and urbanization impacts. Water, 6, 976-992. 
APPENDIX A - Calculation memorial

Calculation for 2025

Hydrological risk and return period

$R=1-[1-P(X \geq x)]$ Eq. 1

$T=\frac{1}{P(X \geq x)}$ Eq. 2

$R=1-\left\lfloor 1-\frac{1}{T}\right\rfloor$ Eq. 3

Adopting T 5 years (as recommended by Tucci et al.,1993), we have:

$\mathrm{R}=1-(1-1 / 2)=\mathbf{R}=\mathbf{0 , 2}$

\section{Contribution drainage area and occupation scenario}

The determination of the contribution area was based on topological map and on verification in the field. For the area 4 (deployment of bioretention basin) the contribution of the total area $A=23714 m^{2}$.

\section{Soil properties}

Soil types were divided into sealed area, APP (vegetation) and pasture, having respective CNs 91,77 and 79.

In 2025, occupation was considered on campus 50\%, with a total area of APP $0 \%$ and $50 \%$ pasture. As the area has more than a group of land use and occupation, an average CN was calculated according to Eq. 8 .

$$
C=\frac{\sum A \cdot C}{\sum A}
$$

Where: Ai corresponds to the area of i-th basin portion corresponding to $\mathrm{CN}_{\mathrm{i}}$ coefficient.

Then:

$\mathrm{CN}=(0,5 * 10337 * 91)+(0 * 10337 * 73)+(0,5 * 10337 * 79) / 10337=\mathbf{C N}=\mathbf{8 5}$

Rainfall intensity and total rainfall

$i=\frac{a \cdot T^{n}}{(t+b)^{m}}$ Eq. 4

$P=i . t$ 
It was used as coefficients $\mathrm{a}, \mathrm{b}, \mathrm{n}$ and $\mathrm{m}$ to the equation proposed by Barbassa (1991), where a $=1519, \mathrm{~b}=16, \mathrm{n}=0.236 \mathrm{~m}=0.935$.

To the time $\mathrm{T}$ rain, there were several rainfall intensity curves as a function of time $t$ rain. The return time was ranging from 2 to 10 years. It was found that for the 20 minutes before beginning the curves almost coincide.

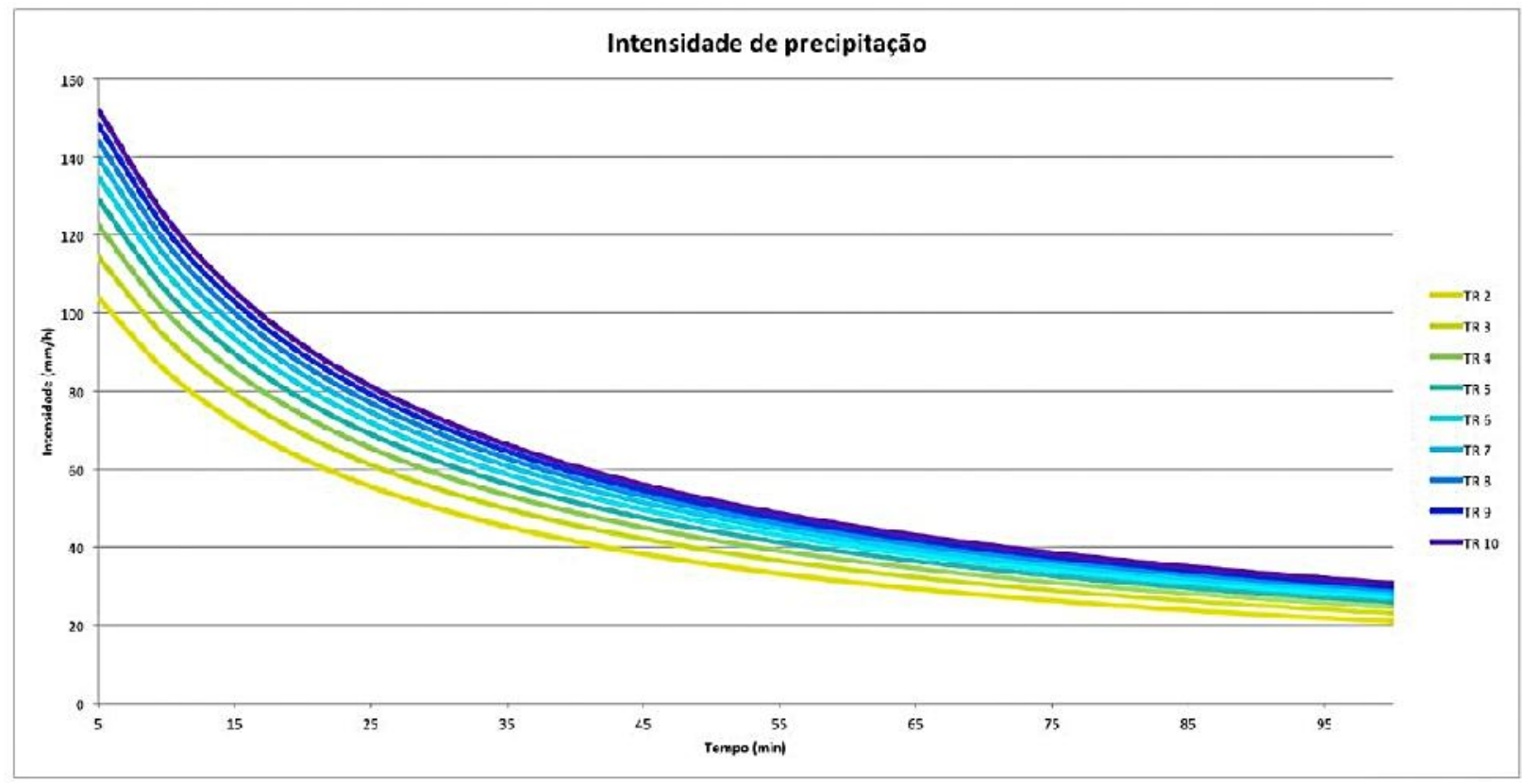

Rainfall intensity curves for return times of 2 to 10 years

Thus, adopting $\mathrm{T}=5$ years and $\mathrm{t}=20$ minutes, we have:

$\mathrm{i}=1519 * 5^{0,236} /(20+16)^{0,935}=\mathrm{i}=\mathbf{7 7 . 8 7} \mathbf{m m} / \mathbf{h}$

The precipitation was, then, calculated:

$\mathrm{P}=77.87 \mathrm{~mm} / \mathrm{h} .20 \mathrm{~min}=\mathbf{P}=\mathbf{2 6} \mathbf{~ m m}$

Effective rainfall

I $P>0.2 S \rightarrow P=\frac{(P-0.2 S)^{2}}{P+0.8 S} ; I: P \leq 0.2 S \rightarrow P=0 \quad$ Eq. 6

$\begin{array}{lll}S=\frac{2}{C}-254 & \text { Eq. } 7\end{array}$

Where: Pe corresponds to effective rainfall; $\mathrm{P}$ to rainfall; and $\mathrm{S}$ to ground potential retention.

$\mathrm{S}=(25400 / 85)-254=44,823 ; 0,2 \mathrm{~S}=8,96$

As $\mathrm{P}>0,2 \mathrm{~S}$, we have: $\mathrm{Pe}=(26-8,96)^{2} / 26+0,8.44,823=\mathbf{P e}=\mathbf{4 , 7} \mathbf{m m}$ 
Runoff coefficient

$C=\frac{P}{P}$

Eq. 9

$\mathrm{C}=4.7 / 26=\mathbf{C}=\mathbf{0 , 1 8}$

Peak flow

$Q_{p} \quad=$ C.i.A

Eq. 10

Qpeak $=0,18.77,87 \mathrm{~mm} / \mathrm{h} \cdot 23714 \mathrm{~m}^{2}=$ Qpeak $=\mathbf{0 , 0 9 2} \mathbf{~ m}^{3} / \mathbf{s}$

Calculation for 1900

Soil properties

For the year of 1900 , it was considered the pre-urbanization, so $100 \%$ of vegetable type was forest cover, and $\mathbf{C N} 77$.

Effective rainfall

I $P>0.2 S \rightarrow P=\frac{(P-0.2 S)^{2}}{P+0.8 S} ; I \quad P \leq 0.2 S \rightarrow P=0 \quad$ Eq. 6

$S=\frac{2}{C}-254$ Eq. 7

Where: Pe corresponds to effective rainfall; $\mathrm{P}$ to rainfall; and $\mathrm{S}$ to ground potential retention.

$\mathrm{S}=(25400 / 85)-254=75,9 ; 0,2 \mathrm{~S}=15,18$

As $\mathrm{P}>0,2 \mathrm{~S}$, we have: $\mathrm{Pe}=(26-15,18)^{2} / 26+0,8.75,9=\mathbf{P e}=\mathbf{1 , 3 5} \mathbf{m m}$

Runoff coefficient

$C=\frac{P}{P}$

Eq. 9

$\mathrm{C}=1,35 / 26=0,0519 ; \mathbf{C}=\mathbf{0 , 0 5 2}$

Peakflow

$Q_{p} \quad=$ C.i.A

Eq. 10

Qpeak $=0,052.77,87 \mathrm{~mm} / \mathrm{h} .23714 \mathrm{~m}^{2}=$ Qpeak $=\mathbf{0 , 0 2 7} \mathbf{m}^{3} / \mathbf{s}$ 
Calculation of sizes

Storage

Having pre-urbanization data (1900) and scenario building (2025), so it made a difference of pre-urbanization and current blades, as Eq 16 and 17:

$\begin{array}{lr}S=\frac{P_{i}-P p u}{1} . A & \text { Eq. } 16 \\ V_{C}=\frac{1 . S}{n} & \text { Eq. } 17\end{array}$

Where: $\mathrm{n}$ is media material porosity.

$\mathrm{S}=((4,7 \mathrm{~mm}-1,35 \mathrm{~mm}) / 1000) .23714=\mathbf{S}=\mathbf{7 8 , 9} \mathbf{m}^{\mathbf{3}}$

Adopting porosity of $34 \%$ (weighted average of sand and gravel), we have:

Vcell $=100.78,9 / 34=$ Vcell $=\mathbf{2 3 2 , 9} \mathbf{m}^{3}$

Considering fixed depth of $\mathbf{P}=\mathbf{3 , 2} \mathbf{m}$ and surface area of rectangular $\mathrm{CT}$ width $\mathbf{L}=\mathbf{5 , 6} \mathbf{m}$, we have:

Vcell $=$ P.L.C

Thus, length of $\mathrm{C}$ bioretention basin is equal to:

$\mathrm{C}=\mathrm{V} / \mathrm{P} . \mathrm{L}=232,9 / 3,2 \times 5,6=12,99 \mathrm{~m} ; \mathbf{C}=\mathbf{1 3} \mathbf{m}$

For the years 2015 and 2100, the same way calculations were made, considering the values of the parameter for the respective years.

Simulations of input hydrograph, output, storage volume and infiltration were based on PULS method and extensive calculations that have been developed in Excel spreadsheets.

Through the mosaic images, it is possible to view the progress of the construction of bioretention system. The images show the evolution from the choice of the area, even with the native vegetation, as well as the demarcation of the boundary, through all construction stages, reaching the operation of the input spillway. 
APPENDIX B -Photographic memorial
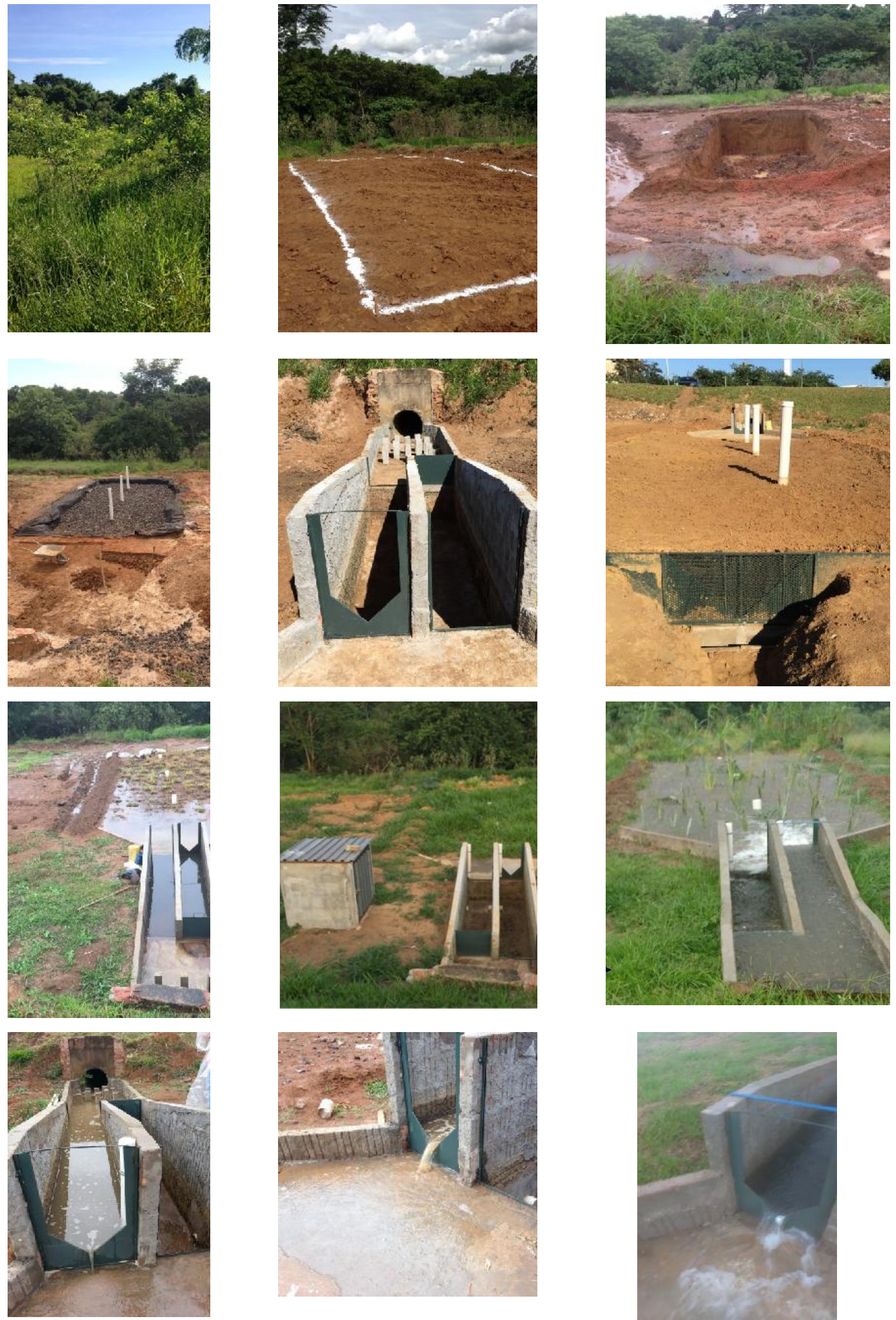

Steps of the construction of CT at campus area 2. 
APPENDIX C - Illustrative scheme of parameters of sizing equations

Flow detention sizing $\left(V_{\text {max,quanti }}, e f f \Delta Q_{\text {quanti }}\right)$
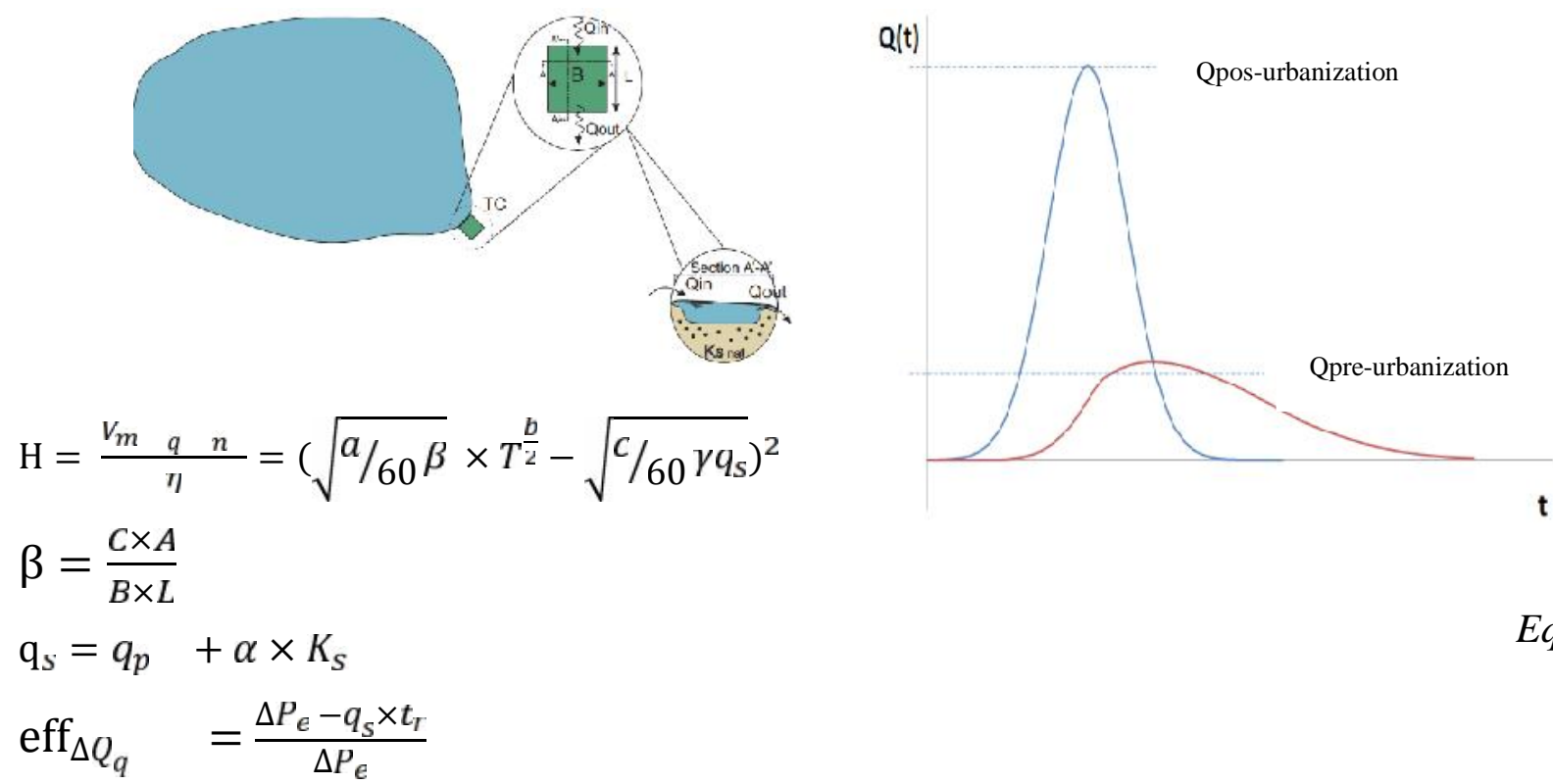

\section{,}

Eq. 18

Demonstrative scheme of compensatory technique

where $V \max _{\text {quanti }}$ is the pre-sizing volume (mm) to mitigate the excess of urban drainage $\Delta P_{e} ; a, b$ and $c$ are the parameters of the IDF equation; $i$ is the rain intensity $\left(\mathrm{mm} \mathrm{h}^{-1}\right) ; T$ is the return period (years); $\mathrm{t}_{\mathrm{r}}$ the rain duration $(\mathrm{min}) ; q_{s}$ is the outflow of the device $\left(\mathrm{mm} \mathrm{h}^{-1}\right) ; A$ is the area contributing to the device; $C$ is the flow coefficient of the contribution area; $L$ and $B$ represent the length and width of the device (m); $\eta$ is the porosity of the filler material of the device; $\gamma$ is the ratio between the percolation area and volume of the device $(\mathrm{mm}) ; \beta$ is the flow coefficient product for the ratio between the contributing area and the device area; $K_{\text {sat }}$ is the saturated hydraulic conductivity of the soil $\left(\mathrm{mm} \mathrm{h}^{-1}\right) ; \alpha$ is the reducing coefficient of the infiltration efficiency due to clogging; and $q_{\text {pre }}$ is the flow restriction, according to an environmental flow or pre-development set in the Drainage Master Plan. 
Pollutant load detention sizing ( $V_{\text {max,quali }}, e f f \Delta Y$, quali $)$

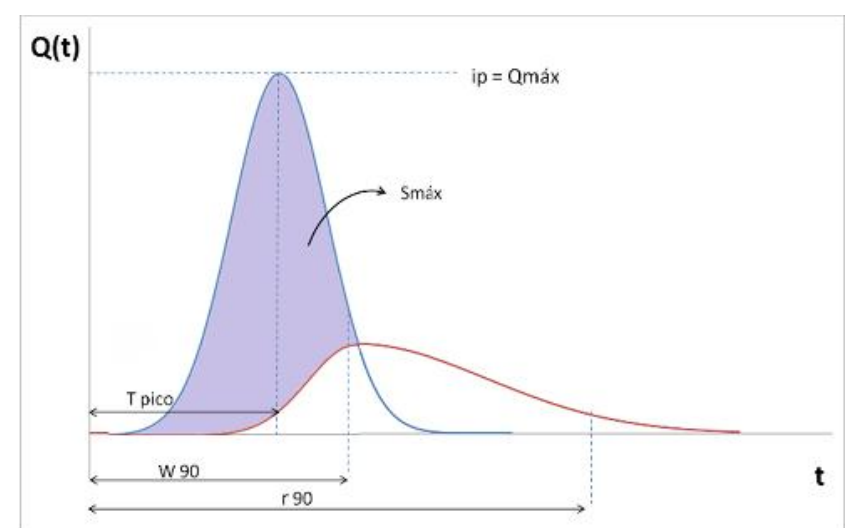

$\mathrm{V}_{\mathrm{q}}=b_{q} \quad \times h^{c_{q}} \quad \mathrm{P}=$

$\frac{k_{U} u_{0} \sqrt{2 g}}{i_{p}}\left(\frac{i_{p} \times t_{p}}{b_{q}}\right)^{0,5 / c_{q}} \quad$ (Orifice output)

$\mathrm{P}=\frac{k_{w} L \sqrt{2 g}}{i_{p}}\left(\frac{i_{p} \times t_{p}}{b_{q}}\right)^{1,5 / c_{q}} \quad$ (Spillway output)

$\mathrm{W}=\frac{w_{9}}{t_{p}} ; R=\frac{r_{9}}{t_{p}} ; S_{a}=$

$\frac{v_{m, q}}{i_{p} \times t_{p}} ; t_{d} \quad(j)=\frac{v_{m}, q}{u_{S}(j)}$

$\operatorname{eff}_{\Delta Y, q} \cong \operatorname{eff}_{\mathrm{re}} \quad, 9 \% \Delta \mathrm{Y}=0,9 \sum_{j-1}^{N_{T}} \frac{t_{r_{1}} \quad 0}{t_{d} \quad t \quad(j)}$

Illustration by maximal volume graph retained by Compensatory Technique. Noteworthy are the periods of time Tpeak, W90 and r90, explained below

where $V_{\text {quali }}$ and $h_{\text {quali }}^{c}$, respectively, are the volume and detention water depth to control the drainage quality, measured above the outflow structure; $\mathrm{c}_{\text {quali }}$ and $\mathrm{b}_{\text {quali }}$ represent the parameter; $k_{o}$ is the dimensionless discharge coefficient of the orifice; $a_{o}$ is the orifice area; $g$ is the gravitational acceleration; $i_{p}$ the maximum discharge of the input flow; $t_{p}$ the maximum discharge time; $k_{w}$ the dimensionless discharge coefficient; $L$ is the width of the spillway crest; $w_{90}$ is the time period in which at least $90 \%$ of the runoff will be detained in the CT; $r_{90}$ is the time in which $90 \%$ of the flow will be evacuated from the CT; $V_{\text {max, quali }}$ is the maximum volume of water that will be stored in the CT; $t_{\text {retention }}$ is the time required for the retention of total suspended solids; $t_{\text {detention(j) }}$ is the detention time required; and $u_{S T T(j)}$ is the settling velocity of the $j$-th fraction of the total suspended solids; and effremoval, $90 \% \Delta_{\mathrm{Y}}$ represents the overall removal efficiency of $90 \%$ of the diffuse pollution load by the transport of suspended solids. 
Sizing with bioretention $\left(V_{\max , b i o}, e f f_{\Delta X, b i o}\right)$

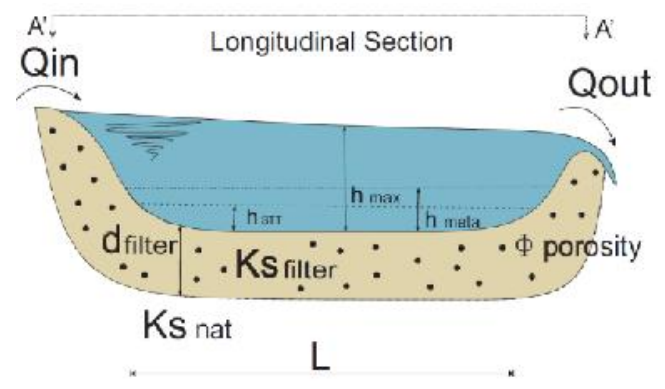

Sizing with bioretention $\left(V_{\max , \text { bio }}, e f f_{\Delta X, \text { bio }}\right)$

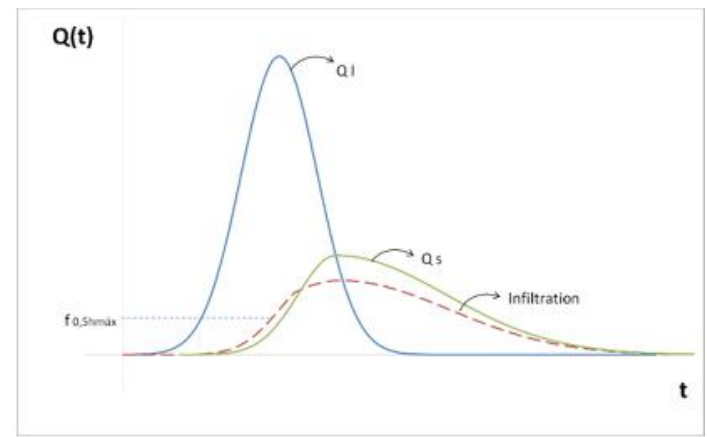

Flow detention sizing ( $\left.V_{\text {max,quanti }}, e f f \Delta Q_{\text {quanti }}\right)$

$$
L_{b}=\frac{Q_{m}, \Delta P}{n_{m}\left(\frac{B_{h, f} d}{t_{b}}+\frac{K_{S} \cdot B_{h, f}}{d_{b}}\right)} f_{m}, b=
$$$$
K_{S} \cdot L_{b} \cdot B_{b} \cdot \frac{n_{m}+d_{b}}{a_{b}}
$$

$$
\begin{aligned}
& T_{b i} \quad=\frac{L_{b}}{f_{h-0.5 m}} \cdot\left(\varnothing \cdot B_{b}+B_{h, f} \quad . h_{m} \quad e . \Delta X, b\right. \\
& =1-\left[1+\frac{1}{n} \cdot \frac{u_{S}}{Q_{m}, \Delta P / A_{b}} \cdot \frac{\left(h_{S}+h_{m}\right)}{\left(h_{m}+h_{m}\right)}\right]^{-n}
\end{aligned}
$$
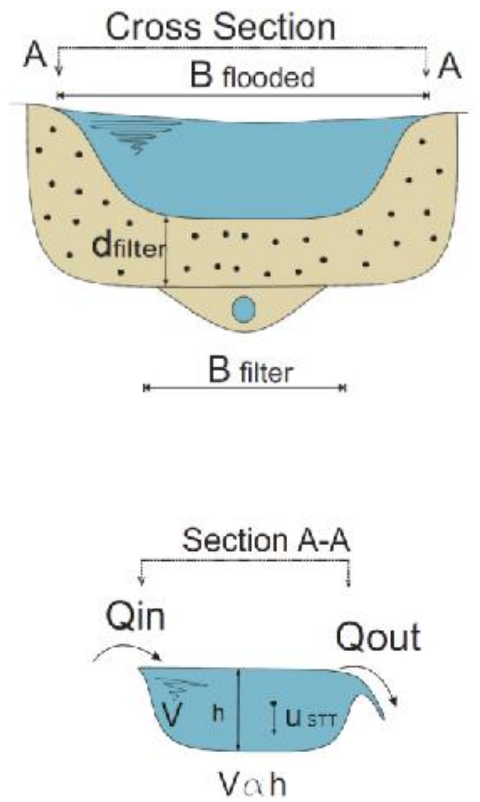

Pollutant load detention sizing ( $V_{\text {max,quali }}$, eff $\Delta Y$, quali)

Schematic sections of Compensatory Technique, demonstrating the retention and infiltration.

where $L_{\text {bio }}$ is the length of the bioretention zone in the CT; $Q_{\text {max, } \Delta \mathrm{Pe}}$ is the maximum discharge rate that enters the bioretention zone according to the increase of the runoff range; $B_{\mathrm{h}, \text { alagado }}$ and $B_{\text {bio }}$ represent, respectively, the average width of the flooded cross-sectional area in the bioretention zone and width of the bioretention zone; $K_{\mathrm{s}}$ is the saturated hydraulic conductivity of the soil; $h_{\max }$ represents the maximum flooding depth above the bioretention zone; $d_{\text {biofilter }}$ is the depth of the biofilter; $C T$ is the concentration time of the drainage area of the micro-basin tributary to the $\mathrm{CT} ; f_{\mathrm{h}=0,5 \mathrm{hmax}}$ represents the infiltration rate for water height equal to half of the maximum flooding layer; $\varnothing$ is the soil porosity; $n$ an empirical hydraulic parameter of turbulence proposed by Fair \& Geyer (1954), and for pre-sizing purposes, it is used close to 1.33 (PGC, 2009, p. 47); the bioretention efficiency eff $\Delta \mathrm{X}$,bio depends on the hydraulic load rate, defined as the quotient $Q_{\max , \Delta \mathrm{Pe}}$ and $A_{\text {bio }}$; $h_{\text {STT }}$ which is the clogging depth of the biofilter; and $h_{\text {meta }}$ which is the intermediate depth to meet the removal goal of pollutant loads by means of the flooding biofilter. The advantage of using the bioretention equations is the incorporation of parameters such as the basin concentration time and hydraulic criteria for the system on which the CT will be sized. 


\title{
4. BIORETENTION AS A CONTROL TO URBAN DRAINAGE SYSTEM WITH AN ECOHYDROLOGICAL BASE: GIS AS A TOOL ON DECISION MAKING
}

\begin{abstract}
Ecohydrology indicators stand out as tools for analyzing the human connection with the environment. Such indicators, together with cleared technology of Geographic Information Systems (GIS) can assist in planning the sustainable use of urban areas susceptible to flooding. In this regard, the present research demonstrates, using GIS tools, along with the study of ecohydrology indicators a more precise analysis of likely areas to build bioretention techniques. The study area is located in São Carlos- São Paulo - Brazil. It can be verified, with the results of the comparison between the scaling method proposed, BIoREteNtIon CEll method - BIRENICE, and the consolidated model, Hydrologic Engineering Center Hydrologic Modeling System (HEC-HMS), that the proposed method is, in fact, effective. This affirmation is based upon the good results found in both parameters analysis, qualitative and quantitative. Through GIS, it is possible to obtain further details of the concerning area, considering the terrain peculiarities as waterproof cutouts, vegetated areas and the distance from water bodies, favoring the magnitude analysis of the impact the bioretention implementation technique considering a temporal evolution of the use and occupation of the area between 2004 and 2014. The results of the qualitative and quantitative monitoring of the implemented system showed a considerable improvement in the analyzed parameters, thus, contributing to the sustainability of the watershed. Through maps, it was possible to observe changes in land use and occupation, identifying decreased features related to area permeability. The image processing favored quantification. That, therefore, favored calculation through a natural runoff coefficient method in conjunction with the rational method. From the preparation of flow scenarios, it was possible to observe the extents of the impact on the runoff, land use and occupation. It is concluded that this methodology is efficient and can be considered as a support tool for watersheds management.
\end{abstract}

Keywords: GIS, bioretention, ecohydrology, urban drainage, land use.

\subsection{Introduction}

Since the 1960s, the urban drainage started to appear as a solution to public policies. Considering this, master plans started to aim the development bases aligned with the protection of the natural resources. The attention of researchers and technicians tended to transcend the water courses to tackle problems from an external approach. This happened mainly because of the development (Geldof, 1995; Pompeo, 2000).

Continuous urban development has resulted in a number of negative environmental impacts. An example of impact this is the increase in impermeable areas (Hatt et al., 2004) reflecting on the increase of surface runoff (Wenguer et al, 2009; Debusk, Hunt \& Line, 2010) and the carriage of pollutants to water bodies, compromising the natural ecosystems (Cianfrini, Hession \& Rizzo, 2006). 
The increase in the use of impermeable surfaces that follows urban growth in recent decades has raised the volume of drained rainwater and pollution that is carried from these waters to the receiving water bodies. Therefore, the management of stormwater in urban areas has become a priority for new planning projects and urban water managements (Lucke \& Nichols, 2015).

The bioretention techniques for urban drainage systems transpas the mitigation potential impacts caused by urbanization, promoting the improvement of the water quality stemmed from catchments (Barbosa et al., 2012), considering the different levels of development of urban infrastructure. Therefore, these techniques can generate alternatives for the management of water resources and environmental protection (Azami et al, 2015; Colson, 2015; Liu et al, 2015; Gessner et al, 2014; McCleary \& Hassan., 2008).

Bioretention systems have been widely implemented in urban areas over the past decade to manage stormwater, reducing peak flows and downstream pollution loads (Lucke \& Nichols, 2015). Part of the reason for the recent popularity of bioretention systems is the flexibility of its design, that helps with its relatively simple integration in existing urban areas. They are also considered supplement to a range of benefits, in addition to the conventional functions of stormwater management, also including aesthetic and social benefits (Chahal et al., 2016). Bioretention systems are generally systems based on plants and soil that typically consists of a filter media (typically sand) and also comprises a drainage layer of gravel (Li \& Davis, 2016; Sample \& Lucas, 2014). The systems can be assembled with any type of geotextile to allow infiltration or include a waterproof lining to help capturing rainwater and reuse it (FAWB, 2009). Bioretention systems treats stormwater through a range of physical, chemical and biological processes. These include mechanical filtration, sedimentation, adsorption, absorption plant and microbial (Mullane, et al., 2015).

Although promising, there are still some difficulties in the implementation of bioretention techniques to consider. Some variables, such as: proximity to water bodies, builtup areas and preservation areas, soil type, contribution points and climatic characteristics of the region should be observed and studied thoroughly to meet the specific standards to enhance the process's efficiency. (Dokulil, 2015).

In parallel, the ecohydrology emerges as a tool that assists the understanding of hydrological mechanisms (Zalewski, 2002) through ecological paths and processes and must observe the dynamics of ecological systems, hydrology and types of land use and occupation by establishing connections between them (Liu, 2011; Zalewski, 2000; Zalewski et al, 2016.). 
Geoprocessing tools help in urban planning and managing areas in its several aspects, allowing the interpretation of satellite and mapping of urban areas images, showing different levels of details and spatial spectrum (Martin-Mikle et al., 2015).

In this perspective, the objective of this study is to evaluate the susceptibility of the area to the implementation of compensatory techniques through ecohydrological and geoprocessing base. The methodology addresses the observation of local characteristics, the inflow of catchment area, building bioretention systems, water quality in the system and its possible interference with the basin. In case of flood events, the assessment is technically guided with the use of GIS to raise images and maps that describes pre-established situations and future scenarios, determining the $\mathrm{CN}$ (Curve Number) average for sub-areas.

\subsection{Methods}

The data and information collection needed for this study involved the following steps: (I) Identification of areas that are adversely affected by flooding events; (II) Defining the time interval needed to assess growth and urbanization of the area from satellite images; (III) construction of thematic maps from digital images to identify different situations using a geoprocessing tool, so that the identified classes were represented spatially.

Five categories of classification related to land use were created: I) existing forest cover; II) used area for reforestation for commercial purposes; III) area occupied by buildings; IV) paved areas for people to transit; and V) areas with low vegetation and bare ground.

The treatment and digital processing were performed using ArcMap 9.1 software, one component of ArcGis platform of ESRI. The GIS incorporated dataframe layers for Permanent Preservation Areas (APP) and Legal Reserve Area (RL). The Hydro APP layers were developed in consideration of a 50-meter distance from the source and a 30-meter distance from draining areas. These distances follow the guidelines established on the new Brazilian Forest Code (BRAZIL, 2012). A polynomial file was created and the types of land cover were delimited (I to $\mathrm{V}$ described above). Through some image analysis of Google Earth ${ }^{\circledR}$ from 2004 and 2010, a comparison can be made and, thus, assess the incremental change year by year. 


\subsubsection{Study Area}

The selected study area is located in the city of São Carlos in the State of São Paulo Brazil, and makes part of Mineirinho's River Basin. The Mineirinho River supplies $40 \%$ of the water demand of the city of São Carlos (Figure 4.1).

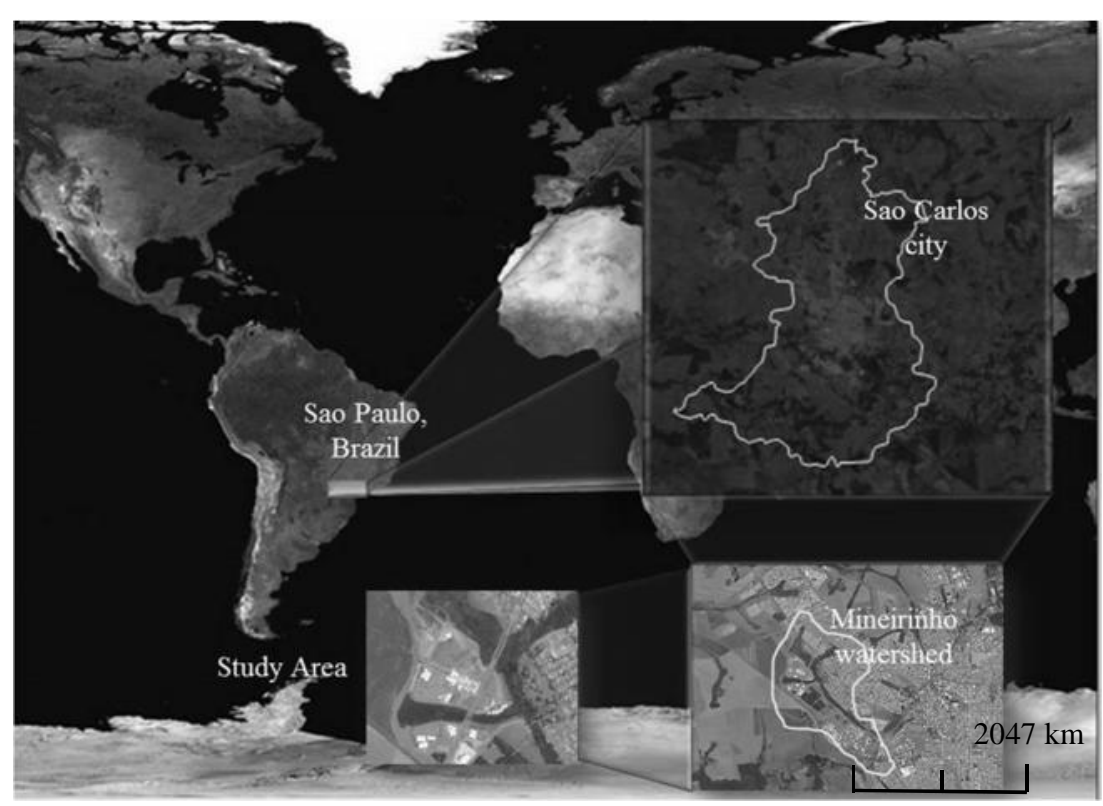

Figure 4.1 - Location map for the Mineirinho’s River basin inside São Carlos

Campus Area 2 of the University of São Paulo - USP - São Carlos has an area of approximately 73 ha, which started to be developed during the late 90s. An additional 29.4 ha. was added to create a total campus size of 102.4 ha., when the university officially opened on April 11 th, 2005. Along side the construction of the university, legal reserves and APPs were recovered. (BENINI, 2005; PUSP-SC, 2015).

Support surveys indicate that the current campus drainage system is insufficient, as periodically several areas of the campus flood during year events. Eight critical areas with inadequate drainage were identified. The implementation of Compensatory Techniques (CTs) in these points can excel as a solution, being investigated in the present work.

The Mineirinho River did not receive a classification by appropriate agencies. However, in consideration of its current conditions in accord with the method developed by Zaffani (2013), Negrão (2015) and Aprígio (2012), we considered that this river is a class 2. According to the Resolution No. 357 of March 17th, 2005 of the Brasilian National Environment Council - CONAMA, which established criteria for the classification of surface 
water bodies and environmental guidelines for its framework, as well as the conditions and effluent discharge Standards, waters from Class 2 Rivers may be used for:

a) The supply for human consumption after conventional treatment;

b) The protection of aquatic communities;

c) The primary contact recreation such as swimming, water skiing and diving;

d) The irrigation of vegetables, fruit trees and parks, gardens, sports and leisure fields, with which the public might have a direct contact with;

e) Aquaculture and fishing activity.

\subsubsection{Runoff Calculation - CN Method}

One of the simplest and most used methods to estimate runoff volume (effective rainfall) resulting from a rainfall event is the method developed by the National Resources Conservation Service of the U.S. (1972) (formerly Soil Conservation Service - SCS). In this method, after determining the total drained volume, one must calculate the peak flow. The Drainage City Manual of São Paulo (São Paulo, 2012) recommends the use of rational method for basins with less than $3 \mathrm{~km}^{2}$. As the application of bioretention catchments occurs even in microdrainage level, the recommendations of the manual and the rational method for calculating the drained peak flow were used. First, it was calculated from the total runoff volume from the determination of effective precipitation, based on Eq. 4.1 and 4.2.

$$
\begin{aligned}
& S \quad>0.2 S \rightarrow P=\frac{(P-0.2 S)^{2}}{P+0.8 S} ; S \quad \leq 0.2 S \rightarrow P=0 \\
& S=\frac{25400}{C}-254
\end{aligned}
$$

Where: $\mathrm{P}$ is the total precipitation in the área; Pe is the effective precipitation; $\mathrm{S}(\mathrm{mm})$ is the ground retention potential, and $\mathrm{CN}$ is the coefficient nunber.

The $\mathrm{CN}$ value depicts the conditions and the soil coverage, varying from a very permeable cover (lower limit value $=0$ ) to a completely impervious cover (upper limit value $=100$ ). The values were tabulated and the hydrologic group of soil and its use and occupation were used as input data. For cases that there are more than one group of soil or use and occupation, the value of $\mathrm{CN}$ was obtained by Eq. 4.3.

$$
C=\frac{\sum A_{i} \times C_{i}}{\sum A_{i}}
$$

Where $A_{i}$ is the $\mathrm{i}$-th portion of the basin which has the $C_{i}$ coefficient ; $C_{i}$ is the coefficient of the $\mathrm{i}$-th portion of the basin. 
The drained peak flow was then calculated using the rational method. The determination of runoff coefficient $(\mathrm{C})$ results from the ratio between the total precipitation volume and the total drained volume, i.e. the ratio between the precipitation and effective precipitation, as shown in Eq. 4.4 (Kawatoko, 2012). This ratio represents the percentage of generation of surface runoff for the contribution area of interest. From the $\mathrm{C}$ relating to the contribution area and the intensity of rainfall, one can obtain the drained peak flow as Eq. 4.5.

$C=\frac{P}{P}$

Eq 4.4

$Q_{p} \quad=$ C.i.A

$E q 4.5$

\subsubsection{Water quality}

Next, the improvement in runoff quality as a result of the bioretention system must be estimated. Samples were collected upgradient of the bioretention system (Figure 4.2a), within the bioretention -system, here called "storage" (Figure 4.2b) and downgradient of the bioretention system (Figure 4.2c). At the upgradient location, samples were collected every five minutes by an autosampler in order to obtain the concentration on the washoff load following the procedure of SILVA et al. (2009). For storage and downgradient locations, samples were collected every 20 minutes throughout the rainfall event.

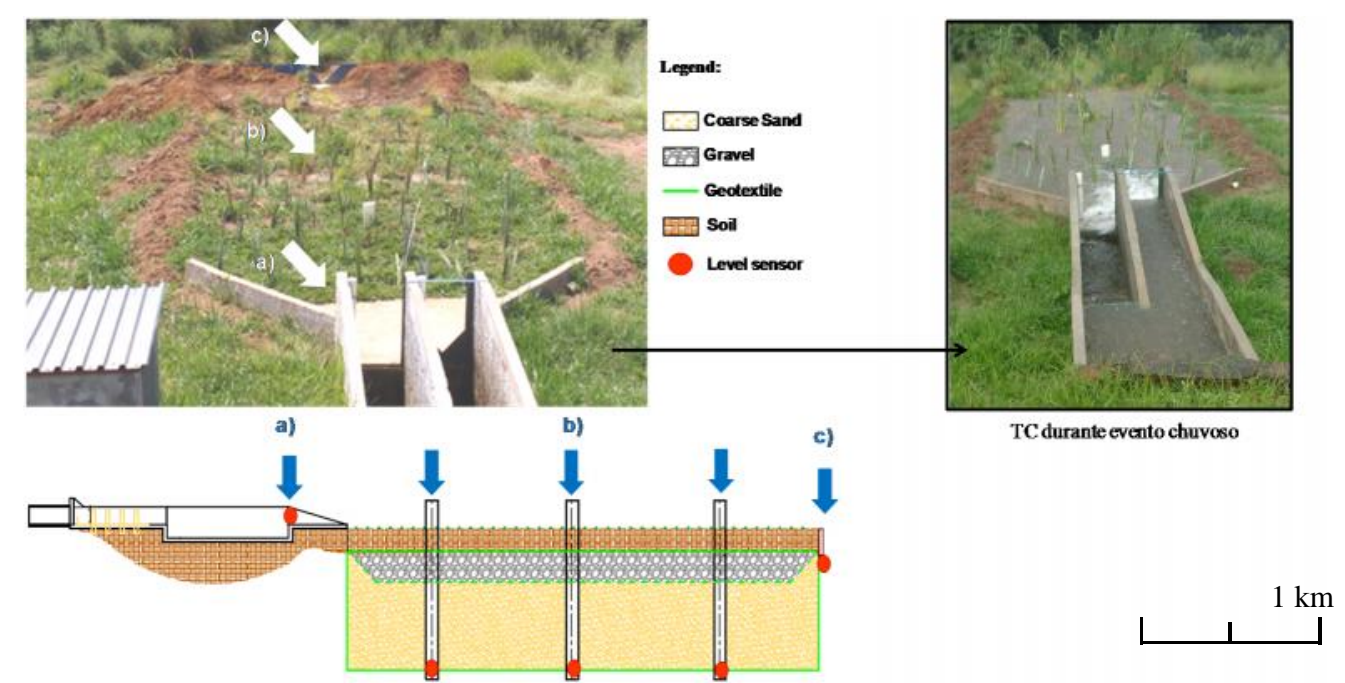

Figure 4.2 - Collecting point for water samples a) input; b) storage, and C) output.

The mass balance, in order to calculate the efficiency of the bioretention system, was done through Eq. 4.6, adapted from Erickson et al. (2013).

$$
M_{S}(t)=\left(M_{i 1}+M_{P}\right)-\left(M_{o}(t)+M_{l}(t)\right)
$$


Where: $M_{s}(t)=$ Polutant's mass stored inside the bioretention system; $M_{\text {in }}(t)=$ Inflow polutant's mass trough runoff; $\mathrm{M}_{\mathrm{P}}(\mathrm{t})=$ Inflow polutant's mass trough precipitation; $\mathrm{M}_{\mathrm{I}}(\mathrm{t})=$ Polutant's mass infiltrated/treated by the CT; $\mathrm{M}_{\text {out }}(\mathrm{t})=\mathrm{CT}$ 's Outflow polutant's mass; $\mathrm{t}=$ interval time.

The studied water quality variables were chosen based upon references from the basic literature. Some works, such as Barbassa (2011) and Vasconcelos (2008), featuring the rainwater drained by a roof in the peripheral region of São Carlos and the main pollutants, were the typical ones of organic contamination by nutrients and metals.

Currently, a great part of studies conducted in this area, analysed the CT's effects on metal treatment. (WANG et al., 2016; WANG et al., 2015; HATT et al., 2009). Therefore, in order to compare the efficiency of the bioretention system in other places, iron - Fe, zinc $\mathrm{Zn}$, lead - Pb, nickel - Ni, manganese - Mn copper - $\mathrm{Cu}$, chromium - $\mathrm{Cr}$ and cadmium - $\mathrm{Cd}$, some parameters were selected as metal contamination of quality variables.

The mass balance's time control and the period of collection of samples, to determine the concentration, at points 1 and 5, are shown in Table 4.1.

\begin{tabular}{lrrr}
\hline & Event 1 & Event 2 & Event 3 \\
\hline Time Control & $0-123$ minutes & $0-136$ minutes & $0-593$ minutes \\
Samples collected (inflow) & $0-30$ minutes & $0-26$ minutes & $0-26$ minutes \\
Samples collected (outflow) & 1 sample at the minute 6 & $25-45$ minutes & $0-60$ minutes \\
\hline
\end{tabular}

Table 4.1 - Time control and collection times of the events.

The time control, applied for this balance, was considered the same as the inflow occurrence duration. However, this period is much longer than the time covered by the sample collection, for the concentration measurements. To overcome this issue, the total inlet and outlet masses, for the events 2 and 3, were calculated through the Event Mean Concentration (EMC). The EMC is given by Eq. 4.7

$E \quad=\frac{\int c_{t} \cdot Q_{t} \cdot d_{t}}{\int Q_{t} d_{t}}=\frac{\sum c_{t} \cdot Q_{t} \cdot \Delta}{\sum Q_{t} \Delta}$

Where the $\mathrm{C}_{\mathrm{t}}$ and $\mathrm{Q}_{\mathrm{t}}$ are the analyzed concentration parameters and the flow rate, at time $\mathrm{t}$, respectively, and $\Delta t$ the interval of each sample collation.

In theory, the event load is calculated by Eq. 4.8, and can be simplified to Eq. 4.9:

$$
\begin{array}{llr}
L & =Q_{m} \cdot C \cdot \Delta t_{c} & E q 4.8 \\
T & L \quad=E \quad . V_{t} & E q 4.9
\end{array}
$$

Where $Q_{m}$ is the mean flow rate, $C$ the concentration and $t_{c}$ the time control. 
Three series of data were obtained from the bioretention system, placed in the Mineirinho's river watershed, for three rainy events, between the months of August and September 2015.

\subsection{Results and Discussion}

\subsubsection{Geoprocessing use}

Using ArcMap 9.1 software we have developed maps for classification of land use and occupation. For the construction of the maps, we considered images taken in 2004, 2010 and 2014 (Figure 4.3). This period was chosen due to the construction of the university's campus: this area passed through very significant changes in its land use and occupation.
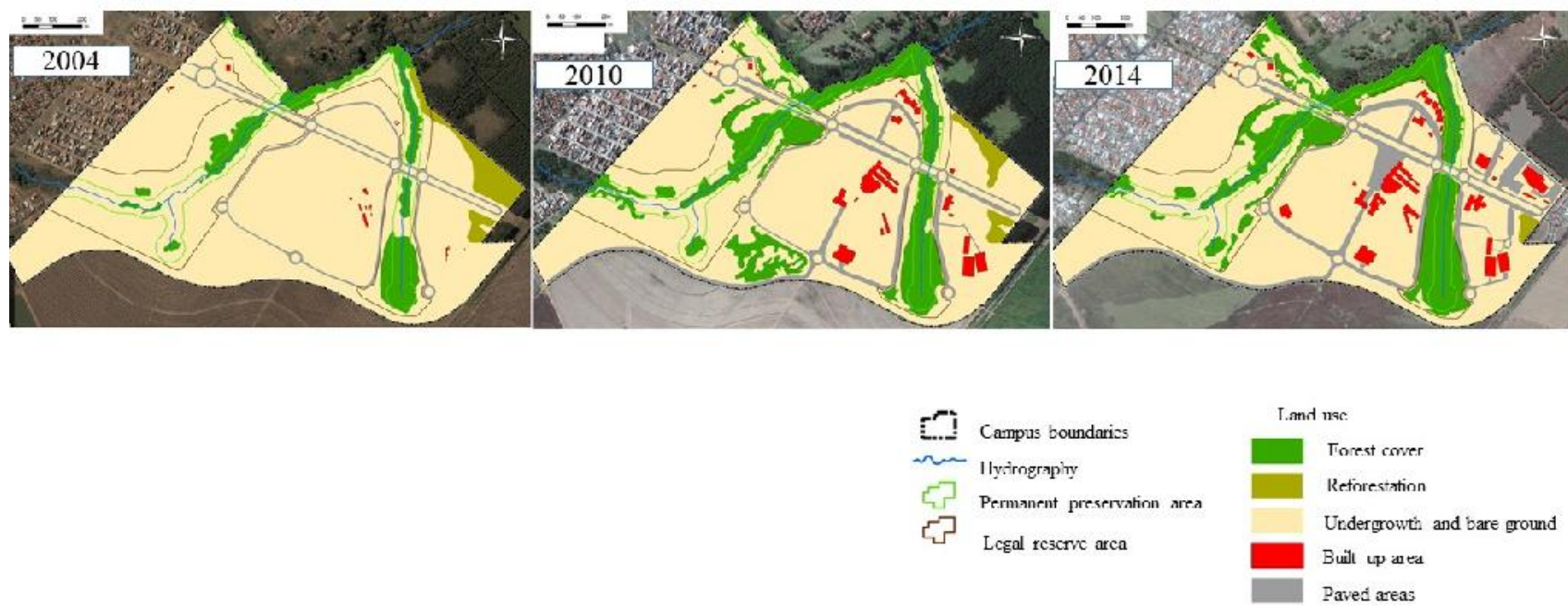

Figure 4.3 - Use and Occupation - Mapping for 2004, 2010 e 2014.

In Figure 4.3 , it is possible to identify features that indicate a decrease of the permeable area, which may result in increased formation of sediment targeted to the water body.

The mapping shows the permanence of underbrush and riparian vegetation at the locations all over time, showing the preservation of these areas, despite moderate changes in the region. So, the bioretention techniques to be adopted should primarily support the preservation of these areas.

The identification of changes in the features on the maps as the borders of built-up area and reforestation indicates changes in both the soil morphology and the areas of use, which implies a decrease in soil permeability. These changes may also be associated with climatic variations of the region. Gordon and Meentemeyer (2006) demonstrated, in their study, the effects of urban drainage systems on the ground vegetation. The formation of 
climatic cores in regions, where there are built-up areas facing ciliary forests, are common and changes the local environment. Thus, the flow associated with soil disturbance causes major impact on local environment.

The variables identified in the features of the maps strongly justify flood zones and suggests that conventional drainage methods would not cause improvements in the region. The patterns of the maps suggest that urban drainage techniques for bioretention should consider the hydro-geomorphologic and ecohydrological processes and, also, the relationship between discharge and sediment carried in their constructive step.

\subsubsection{Use Quantification}

Through the processing of the images, it was possible to identify and quantify the types of soil use and occupation at campus 2 of USP São Carlos (Table 4.2).

\begin{tabular}{lrrr}
\hline Area $\left(\mathrm{m}^{2}\right)$ & $2004\left(\mathrm{~m}^{2}\right)$ & $2010\left(\mathrm{~m}^{2}\right)$ & $2014\left(\mathrm{~m}^{2}\right)$ \\
\hline Built-up Area & 2142 & 22584 & 36230 \\
Paved area & 36521 & 72916 & 111619 \\
Forest cover & 85156 & 179839 & 184368 \\
Comercial Reforestation Area & 36026 & 17924 & 4303 \\
Bare or ground vegetation area & 863886 & 730467 & 687210 \\
\hline
\end{tabular}

Table 4.2 - Evolution of land use at Campus 2 - São Carlos (USP).

Based on the data presented in Table 4.2, it can be observed that there was an increase in built-up and paved areas as well as forest coverage area over the years. It is possible to infer that there was an increase in the sealed area within the campus from the increase in paved and built-up areas, which changed from $3.78 \%$ to $14.44 \%$ of the total area of the campus. The increase of built-up area reflected in increased soil sealing, raising the water runoff. Therefore, there is greater amount of sediment taken at a higher speed to the receiver body and it may increase its sedimentation level.

In 2014 , the sealed area was around $14.44 \%$ of the total of Campus 2. It was also identified that the area of legal reserve represents around $20.7 \%$ of the campus. According to the Forest Code, the area required by law is $20 \%$, leaving approximately $0.7 \%$ of the area suitable for further construction of techniques that allows better water runoff such as bioretention systems.

While Evaluating the results with previous research on the characterization of the Mineirinho Stream Basin, in terms of use and occupation, it is clear that Campus 2 followed the pattern of occupation of other areas of the basin, with an increase in impervious areas by construction of paved roads and built-up areas. Benini (2005) reports that for the year of 1972 
about $75 \%$ of the area comprised pastures and grasses, corresponding to the permeable areas, while little more than 5\% corresponded to impervious areas. In 2000 this scenario changed, increasing to $35 \%$ of impervious areas, with areas of grass reduced to less than half of the coverage. Remaining forest areas decreased from just over $10 \%$ to approximately $5 \%$. Aprígio (2012) reported that in 2012 about $45 \%$ of the area was built with $20 \%$ grasses.

The data obtained from the construction of maps for use and occupation land at Campus 2 demonstrate that, despite following the trend of the surrounding region that also comprises the Mineirinho Stream Basin, this site has a moderately accelerated growth, increasing about $10 \%$ the permeable areas corresponding to reduction in areas with ground vegetation. This demonstrates the need for future planning.

\begin{tabular}{lccc}
\hline Area $\left(\mathrm{m}^{2}\right)$ & $2004\left(\mathrm{~m}^{2}\right)$ & $2010\left(\mathrm{~m}^{2}\right)$ & $2014\left(\mathrm{~m}^{2}\right)$ \\
\hline Forest cover area & 65060 & 96496 & 96088 \\
Comercial Reforestation Area & 78890 & 48315 & 48723 \\
Ground vegetation or bare land area & 860 & 0 & 0 \\
\hline
\end{tabular}

Table 4.3 - Evolution of land uses in the APPs Campus 2 - São Carlos (USP).

\begin{tabular}{lccc}
\hline Area $\left(\mathrm{m}^{2}\right)$ & $2004\left(\mathrm{~m}^{2}\right)$ & $2010\left(\mathrm{~m}^{2}\right)$ & $2014\left(\mathrm{~m}^{2}\right)$ \\
\hline Forest cover area & 19486 & 57974 & 83508 \\
Comercial Reforestation Area & 188771 & 153793 & 128259 \\
Ground vegetation or bare land area & 3509 & 0 & 0 \\
\hline
\end{tabular}

Table 4.4 - Evolution of land uses in the RL Campus 2 - São Carlos (USP).

Table 4.3 and Table 4.4 present data related to the historical evolution in terms of areas of legal reserve (RL) and permanent preservation areas (APP), whose objectives are to correlate with the patterns presented by photo-interpretation. In technical terms, there was no change in the identification method with the respective collected data, indicating that the patterns relate to the decrease in drainage area of the region that enables entrainment of solids to the/a water body. Unlike the surrounding region (Benini, 2005; Aprígio, 2012), one can note that for Campus 2, there was an increase over the years in the area of forest cover and the APP and RL ground vegetation were entirely converted to forest vegetation. This behavior demonstrates the university administration's concern with the improvement of environmental quality and commitment to follow the law.

\subsubsection{Calculation of runoff}

The confirmation and quantification of an increase in the surface runoff were made through the peak flow calculation using the method CN - SCS conjugate with the rational method. To this end, it was adopted different $\mathrm{CN}$ values corresponding to every area of different land use and occupation. The general $\mathrm{CN}$ value was calculated in accordance with 
Eq. 3 and peak flow. For the runoff, it was calculated from Eq. 4.5. In this calculation, a rainfall intensity of $91.7 \mathrm{~mm} / \mathrm{hr}$ was considered, calculated from rain time of $20 \mathrm{~min}$ (more common for the city of São Carlos) and return period of 10 years, set from the Drainage Manual and Stormwater Management recommendations (São Paulo, 2012) for microdrainage. With these input values, the value of precipitation obtained was $30.6 \mathrm{~mm}$

From the $\mathrm{CN}$ distribution calculations and expert analysis, it was considered CN 77 for forest areas - forests in poor condition. The occupied areas were considered industrial districts (72\% waterproofing) with $\mathrm{CN} 91$. For the pasture areas, CN 79 was adopted - pasture in average conditions. For APP (Area of Permanent Protection), CN 73 was adopted - forest in good condition.

To complement the analysis of the increase in runoff with increased urbanization, it was also made a forecast for future scenarios of urban drainage condition in the Campus, in view of the occupations provided by the Master Plan of the Campus Area 2 and the city of São Carlos. Thus, the $\mathrm{CN}$ calculations and drained peak flow were made for the scenarios of 2025 (50\% occupancy), 2050 (75\% occupancy) and 2100 (85\% occupancy) (Figure 4.4). For these scenarios the same $\mathrm{CN}$ values determined previously were considered, with the exception of APP areas, which was adopted CN 77, representing forests in poor condition.

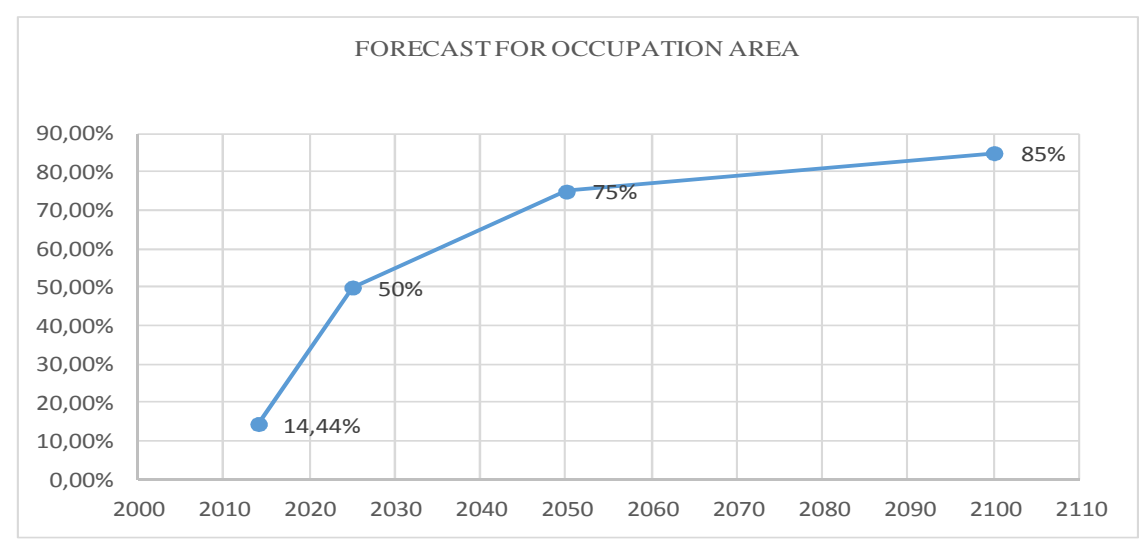

Figure 4.4 - Forecast for occupation of the area.

Table 4.5 shows the flow scenarios obtained for each of the eight catchments (contribution areas) that cover the study area. The drained peak flow rates were calculated based on the $\mathrm{CN}$ values for each contribution area varying according to the percentage of occupation of the campus. The results presented illustrate how changes in the land use and occupation affects indeed the runoff. It may be noted that between the years 2014 and 2025, in which the Campus occupation would double its size, there is a percentage increase in runoff ranging from $13 \%$ (basin 5) to $100 \%$ (basin 7). The maximum expected increase is $214 \%$ occurring in the basin 7 for the 2100 scenario, with higher occupancy rate. 


\begin{tabular}{ccccccccc}
\hline \multirow{2}{*}{ Basin } & \multicolumn{2}{c}{2014} & \multicolumn{2}{c}{2025} & \multicolumn{2}{c}{2050} & \multicolumn{2}{c}{2100} \\
\cline { 2 - 8 } & $\mathrm{CN}$ & Qpeak $\left(\mathrm{m}^{3} / \mathrm{s}\right)$ & $\mathrm{CN}$ & Qpeak $\left(\mathrm{m}^{3} / \mathrm{s}\right)$ & $\mathrm{CN}$ & Qpeak $\left(\mathrm{m}^{3} / \mathrm{s}\right)$ & $\mathrm{CN}$ & Qpeak $\left(\mathrm{m}^{3 / \mathrm{s})}\right.$ \\
\hline 1 & 81,0 & 0,030 & 85,0 & 0,048 & 88,0 & 0,065 & 89,2 & 0,073 \\
2 & 82,0 & 0,246 & 85,0 & 0,346 & 88,0 & 0,472 & 89,2 & 0,532 \\
3 & 81,5 & 0,126 & 85,0 & 0,187 & 88,0 & 0,255 & 89,2 & 0,288 \\
4 & 80,6 & 0,036 & 85,0 & 0,061 & 88,0 & 0,083 & 89,2 & 0,093 \\
5 & 85,6 & 0,009 & 86,8 & 0,010 & 88,0 & 0,011 & 89,2 & 0,013 \\
6 & 83,2 & 0,118 & 84,9 & 0,142 & 87,9 & 0,193 & 88,9 & 0,214 \\
7 & 79,0 & 0,005 & 85,0 & 0,010 & 88,0 & 0,014 & 89,2 & 0,016 \\
8 & 81,3 & 0,141 & 85,0 & 0,215 & 88,0 & 0,293 & 89,2 & 0,331 \\
\hline
\end{tabular}

Table 4.5 - CN Values for contribution areas.

The scenarios observed on the maps composition denote a significant increase of the impermeable area through the classes that indicate constructed areas and by the objects that indicate road expansion. Under these conditions, after local consultations, it can be noticed an increase in volumes of water running into the river studied. Additionally, the hydrological performance can also be compromised over time, because, besides the running, the cycle as a whole is influenced by the permeability coefficients.

\subsubsection{Bioretention based on ecohydrological principles}

The dimensions of the bioretention system followed the criteria, general efficiencies and joint performance and can be checked by comparing the qualitative and quantitative efficiency. In this work, only the qualitative results will be shown, guided by ecohydrological principles, as seen in Figure 4.5, which is illustrative and is not on scale. The diagram shows the contribution areas of the studied catchment regarding the bioretention technique. The influence zones that emerge from the urban growth in the region are also considered. The Mineirinho River has dense riparian vegetation and small pockets of water along its route. The contribution flow is basically from the campus drainage system and rainwater capture. All these components are evaluated in correlation to the ecosystem interactions. Figure 4.6 shows the constructive parameters of implementation of bioretention project.

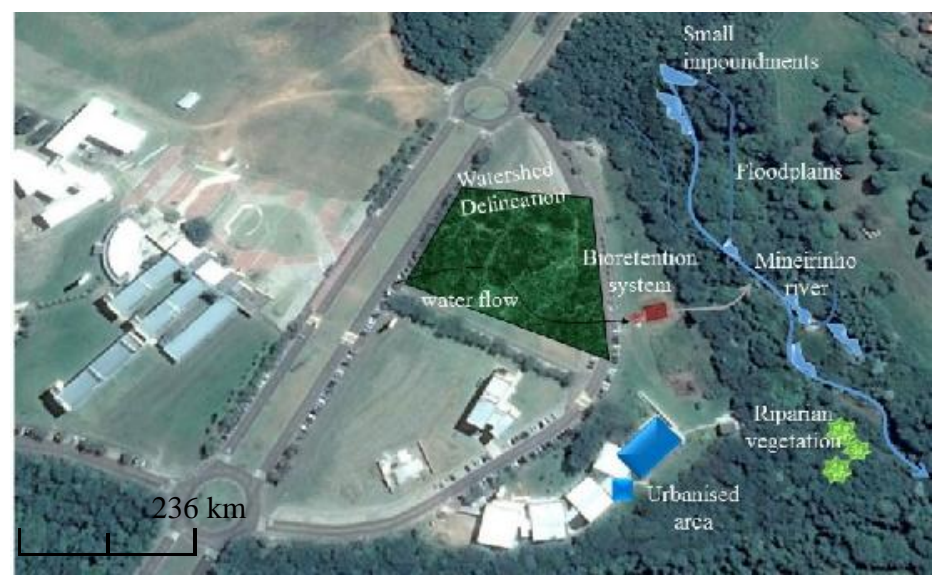

Figure 4.5 - Influence zones and contribution areas for the bioretention technique. 

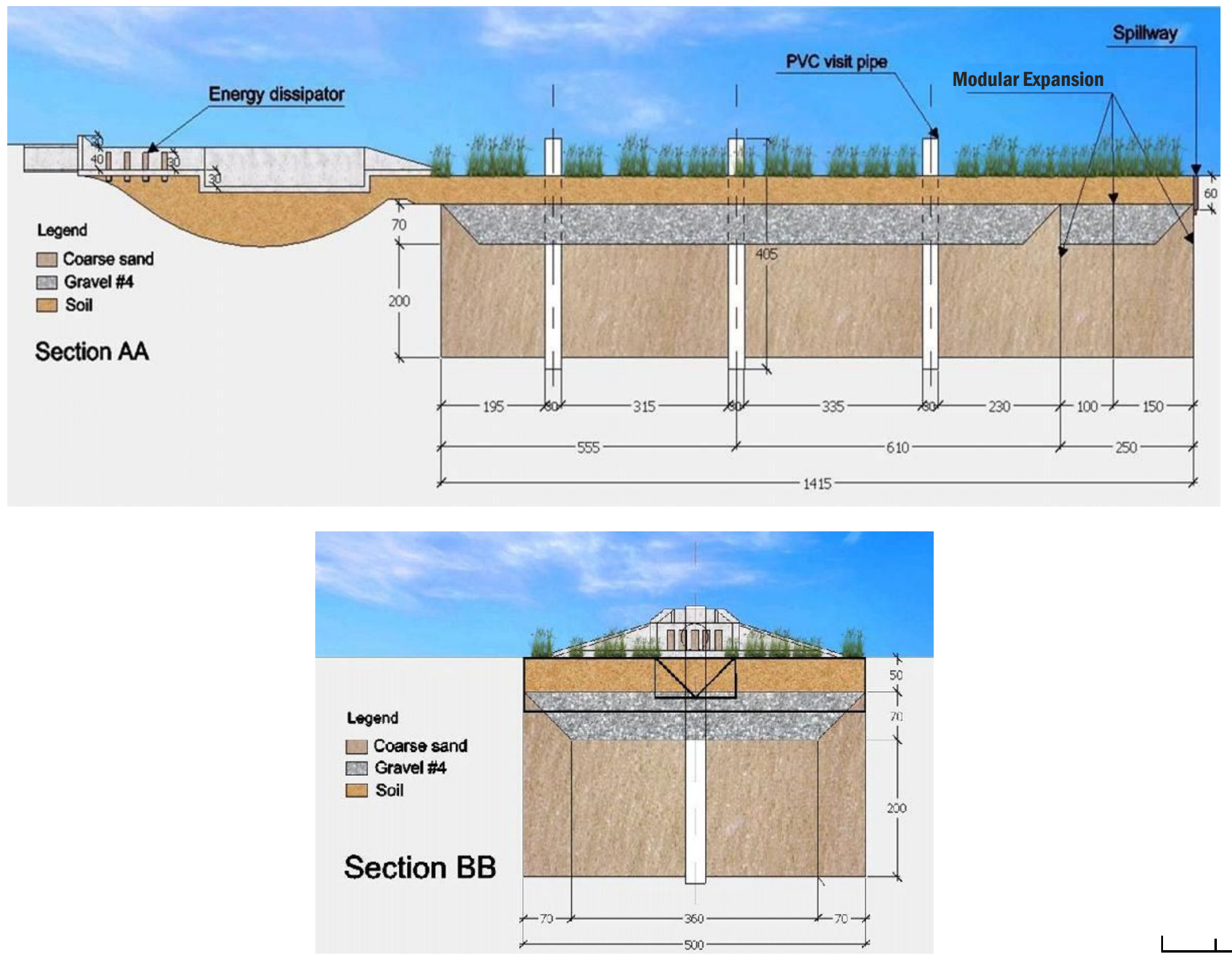

Figure 4.6 - Perspective for implanting the bioretention technique 
The proposed system allows this temporal evaluation for being modularly dimensioned. It allows, without much effort, to expand its size over time. This issue has been considered by the fact that the study area is recent and is in full expansion. It is known that the more urbanized the space is, the more increased the runoff and, hence, larger the bioretention system must be.

\subsubsection{Water quality in Bioretention Systems}

Some analysis of water quality were made at three points in this bioretention experiment - inlet, storage and outlet - in order to characterize the pollution present in the surface runoff and evaluate the efficiency of the technique in removing pollutants. Three rainfall events were considered, in the months of August and September 2015. The Table 4.6 also shows, for means, characteristics of events.

\begin{tabular}{|c|c|c|c|c|c|c|}
\hline \multirow{3}{*}{$\begin{array}{r}\text { Date } \\
\text { 25/ago }\end{array}$} & \multicolumn{4}{|c|}{ Time start /end } & \multirow{3}{*}{$\begin{array}{c}\text { Total precipitation before sampling }(\mathrm{mm}) \\
3.8\end{array}$} & \multirow{3}{*}{$\begin{array}{c}\text { Event total precipitation }(\mathrm{mm}) \\
5.8\end{array}$} \\
\hline & \multicolumn{2}{|r|}{ Rainfall } & \multicolumn{2}{|c|}{ Sampling } & & \\
\hline & $9 \mathrm{~h} 42$ & $14 \mathrm{~h} 17$ & $10 \mathrm{~h} 04$ & $10 \mathrm{~h} 50$ & & \\
\hline 27/ago & $14 \mathrm{~h} 53$ & $17 \mathrm{~h} 47$ & $15 \mathrm{~h} 28$ & $17 \mathrm{~h} 28$ & 2.4 & 2.6 \\
\hline $08 /$ set & $15 \mathrm{~h} 59$ & 1h55 (next day) & $16 \mathrm{~h} 03$ & $17 \mathrm{~h} 59$ & 29 & 39 \\
\hline
\end{tabular}

Table 4.6 - Characteristics of events

The Table 4.7 shows the EMC obtained for the variables: $\mathrm{Fe}, \mathrm{Zn}, \mathrm{Pb}, \mathrm{Ni}, \mathrm{Mn}, \mathrm{Cu}, \mathrm{Cr}$ and $\mathrm{Cd}$, and shows, for means of comparison, the standards established for the effluent released in a Class 2 river, which is Mineirinho's class, according to Brazilian Federal CONAMA 357/2005 resolution. It can be observed that the outlet EMC for $\mathrm{Fe}, \mathrm{Ni}, \mathrm{Cu}$, and $\mathrm{Cd}$, at all three events, and for $\mathrm{Pb}$, in events 2 and 3, presents higher values than the limits established by the CONAMA. However, the total inlet and outlet mass of the parameters should be analyzed to verify the bioretention efficiency and how this system reduces the impact on the receiving water body.

\begin{tabular}{cccccccc}
\hline & \multicolumn{2}{c}{ Event 1 } & \multicolumn{2}{c}{ Event 2 } & \multicolumn{2}{c}{ Event 3 } & Conama 357 \\
\hline & $\begin{array}{c}\text { EMC Inlet } \\
(\mathrm{mg} / \mathrm{l})\end{array}$ & $\begin{array}{c}\text { EMC Outlet } \\
(\mathrm{mg} / \mathrm{l})\end{array}$ & $\begin{array}{c}\text { EMC Inlet } \\
(\mathrm{mg} / \mathrm{l})\end{array}$ & $\begin{array}{c}\text { EMC Outlet } \\
(\mathrm{mg} / \mathrm{l})\end{array}$ & $\begin{array}{c}\text { EMC Inlet } \\
(\mathrm{mg} / \mathrm{l})\end{array}$ & $\begin{array}{c}\begin{array}{c}\text { EMC Outlet } \\
(\mathrm{mg} / \mathrm{l})\end{array} \\
\text { Standars (mg/l) }\end{array}$ \\
\hline $\mathrm{Fe}$ & 15.54 & 36.59 & 10.71 & 4.76 & 0.34 & 1.74 & 0.3 \\
$\mathrm{Zn}$ & 0.143 & 0.123 & 0.230 & 0.09 & 0.09 & 0.09 & 0.18 \\
$\mathrm{~Pb}$ & 0.05 & 0.010 & 0.070 & 0.02 & 0.06 & 0.05 & 0.01 \\
$\mathrm{Ni}$ & 0.068 & 0.095 & 0.070 & 0.09 & 0.06 & 0.11 & 0.025 \\
$\mathrm{Mn}$ & 0.047 & 0.040 & 0.040 & 0.020 & - & - & 0.1 \\
$\mathrm{Cu}$ & 0.014 & 0.014 & 0.020 & 0.01 & - & - & 0.009 \\
$\mathrm{Cr}$ & $<0.005$ & $<0.005$ & $<0.005$ & $<0.005$ & $<0.005$ & $<0.005$ & 0.005 \\
$\mathrm{Cd}$ & 0.03 & 0.033 & 0.03 & 0.03 & 0.08 & 0.08 & 0.001 \\
\hline
\end{tabular}

Table 4.7 - Event Mean Concentration for pollutants in each event 
The rainfall measurements were $6.0 \mathrm{~mm}$ in the first event, $3.0 \mathrm{~mm}$ in the second event and $39.0 \mathrm{~mm}$ in the third event. The Figure 4.7 shows the accumulated and instantaneous water depth, generated by these rainfalls, for each event. It can be observed the infiltration depth in the bioretention, being the difference of the inlet and outlet the water depth. In event one (1) the infiltration rate was approximately $34 \%$, to event two (2) $41 \%$ and, to event three (3), it was $64 \%$. The dashed lines on the graphics delimit the sampling period.
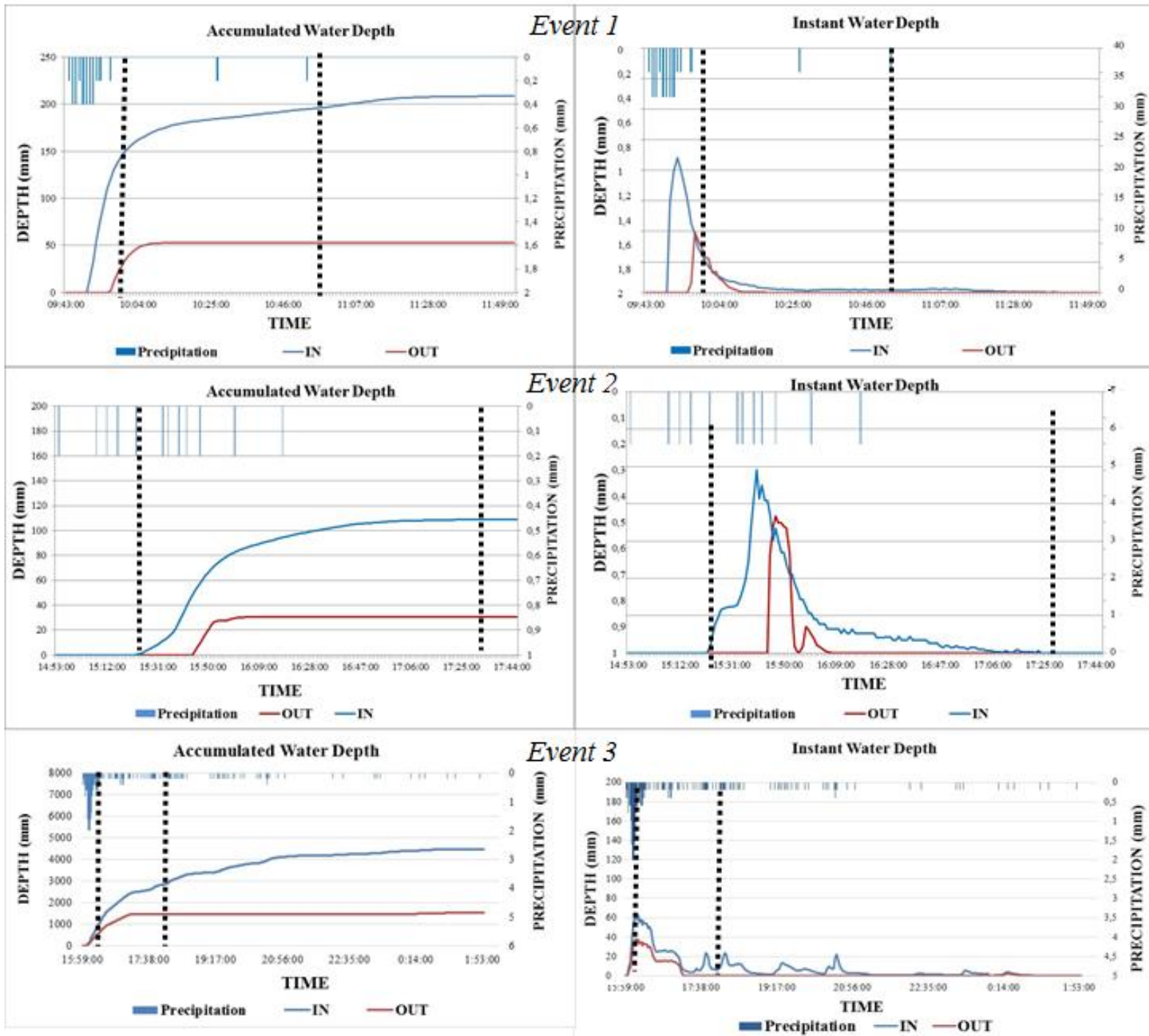

Figure 4.7 - Accumulated and instant depth for events

The inlet and outlet mass of each parameter analyzed and the removal efficiency are shown in Table 4.8. It shows the removal efficiency for the monitored events. It is possible to notice, for most of the parameters analyzed, that the practice decreases the pollutants load, that would have reached the water body, considerably. The chrome concentration measured was insignificant and it is not shown in the table. 
The metal removal efficiency varies from $40.3 \%$ to $97.8 \%$. Lead was the parameter with the higher removal rates $(94.0 \%$ and $91.8 \%$ for the events 1 and 2$)$. Iron had the worst removal efficiency: $40.3 \%$ in event 1 and it had even, for event 3, a higher outlet mass than inlet, resulting in a negative efficiency $(-74.84 \%)$. This can be explained due to the Brazilian soil chemical composition. Due to the geological characteristics and its high weathering levels in tropical regions, it is common to find high iron oxides in the soils like the one used to the superficial and vegetated layer of the $\mathrm{CT}$ in which an erosion occurrence was observed during the event 3. Besides the iron, all other metals, in event 3, had a lower removal efficiency when compared to the events 1 and 2 . The reason may also be related to the soil type in the study area, latosol and erosion events.

\begin{tabular}{|c|c|c|c|c|c|c|c|c|c|}
\hline \multicolumn{4}{|c|}{ Event 1} & \multicolumn{3}{|c|}{ Event 2} & \multicolumn{3}{|c|}{ Event 3} \\
\hline & \multicolumn{2}{|c|}{ Load } & \multirow{2}{*}{ Efficiency } & \multicolumn{2}{|c|}{ Load } & \multirow{2}{*}{ Efficiency } & \multicolumn{2}{|c|}{ Load } & \multirow{2}{*}{ Efficiency } \\
\hline & In (g) & Out (g) & & In $(\mathrm{g})$ & Out (g) & & In (g) & Out (g) & \\
\hline $\mathrm{Fe}$ & 197.70 & 117.93 & $40.3 \%$ & 71.05 & 8.85 & $87,5 \%$ & 92.57 & 161.86 & $-74.8 \%$ \\
\hline $\mathrm{Zn}$ & 1.82 & 0.40 & $78.2 \%$ & 1.50 & 0.17 & $88,7 \%$ & 24.74 & 8.64 & $65.1 \%$ \\
\hline $\mathrm{Pb}$ & 0.64 & 0.03 & $94.9 \%$ & 0.46 & 0.04 & $91,8 \%$ & 15.23 & 4.66 & $69.4 \%$ \\
\hline $\mathrm{Ni}$ & 0.87 & 0.31 & $64.6 \%$ & 0.47 & 0.16 & $65,8 \%$ & 17.12 & 10.14 & $40.8 \%$ \\
\hline $\mathrm{Mn}$ & 0.60 & 0.01 & $97.8 \%$ & 0.23 & 0.04 & $83,4 \%$ & - & - & - \\
\hline $\mathrm{Cu}$ & 0.18 & 0.05 & $74.7 \%$ & 0.12 & 0.01 & $89,4 \%$ & - & - & - \\
\hline $\mathrm{Cr}$ & - & - & - & - & - & - & - & - & - \\
\hline $\mathrm{Cd}$ & 0.38 & 0.11 & $72.1 \%$ & 0.22 & 0.06 & $71,9 \%$ & 20.84 & 7.80 & $62.6 \%$ \\
\hline
\end{tabular}

To complement the results analysis, a review of the metal removal rates obtained by other authors was performed. Wang et al. (2016) studied the Cd removal in several filtrating materials and had over $95 \%$ of efficiency. Wang et al. (2015) also evaluated the $\mathrm{Cu}, \mathrm{Pb}$ and Cd removal by filtration of wastes from construction sites and obtained more than $90 \%$ of efficiency. These values are much higher than those found in this study. However, Wang et al. (2016) and Wang et al. (2015) did these studies under a laboratorial scale with no adversities faced in a field experiment. Hatt et al. (2009), otherwise, analysed the removal efficiency of a bioretention system applied on the field and obtained an efficiency of $67 \%$ and $80 \%$ for $\mathrm{Cu}$ and $\mathrm{Pb}$ respectively. It is important to highlight, that the removal efficiency of a bioretention system varies with its location, due to the different climate conditions and the filtrating material characteristics, as the vegetated layer has a great influence on the runnoff treatment.

Despite the Mineirinho's River Basin be classified as a Class 2 - under Brazilian law, which allows for a more noble use of its waters such as supply for human use and 
primary contact recreation, Aprígio (2012) found illegal contribution of domestic sewage in regions on its head. This may contribute to a loss of environmental quality of the basin, an increase of pollutant concentration in its water and risks to the surrounding population. Thus, some actions to reduce the amount of pollution and consequent improvement in water quality to match its intended uses are important for this region.

\subsection{Conclusion}

The method used for mapping land use and occupation allowed to check and compare the increase in the urban area and its interference with the local environment. Hence, the criteria to define the study area were satisfactory and provided a study model and characterization of the area - more comprehensive and accurate to select sites for construction of bioretention techniques - based on ecohydrological principles. The mapping of land use and occupation groups simplifies the procedures for integrating information regarding the priority areas for the construction of bioretention systems and the particular characteristics of each region, providing the implementation of resource of georeferenced bases directed to ecohydrological issues.

The comparative visual analysis allows an initial assessment, although more superficial, on the quality of the method applied to determine the CN. It is clearly noticeable that there are bigger $\mathrm{CN}$ values in more urbanized areas, where waterproofing percentage is high, associated with soil conditions showing infiltration capacity below the average. The regions of forests and fields are clear indicators of areas where there is less runoff (lower $\mathrm{CN}$ ).

The increase in impermeable areas, even with a slow rate of advancement, increases the quantities of sediments during periods of heavy rainfall, making a high input of sediments in the receiving body, causing the increase of various parameters related to water quality and peak flow. With the implementation of compensatory techniques, this problem is mitigated, lowering the impact in water ecosystems downstream of bioretention technique.

The quality of the output effluent from the bioretention system confirms a significant improvement in the analyzed parameters. It was possible to verify that there is a decrease in the mass loading and, accordingly, improvement in water quality parameters, which contributes to lower of pollutants and contaminants to the receiver. This feature reinforces the capacity of treatment of bioretention technique.

Guided by our studies, we can say that applying this methodology to select areas to implement bioretention system is efficient and proves, with the data presented, the reduction 
of pollutant load directed to the river, being understood that the construction of bioretention techniques, in addition make lower impacting to the river, brings benefits to it. This is justified by the thematic maps, where one can see that there is considerable natural vegetation covering the area, as well as areas that were reforested over time. As for the quality of the output effluent from the bioretention system, it is possible to verify that there is a significant improvement of the analyzed parameters.

The study clearly shows the importance of using a georeferencing tool for analysis of areas, since it enables a rapid and consistent analysis of the study area. When correlation occurs with ecohydrological indicators, the perception of the process efficiency supported with physical elements becomes believable when it is noticed. An example is the investigation of vegetal areas, that together with the results of qualitative parameters, demonstrate that the implementation of a bioretention system attenuates the peak flow effects for a specific region. Studies of this size can support a feasibility analysis and is more accurate in efficiency for regions with different climatic and physical characteristics.

\section{References}

AZAMI, K., SUZUKI, H., \& TOKI, S. (2004). Changes in riparian vegetation communities below a large dam in a monsoonal region: Futase Dam, Japan. River Research and Applications, 20(5), 549-563. http://doi.org/10.1002/rra.763

BARBOSA, A. E., FERNANDES, J. N., \& DAVID, L. M. (2012). Key issues for sustainable urban stormwater management. Water Research, 46(20), 6787-6798. http://doi.org/10.1016/j.watres.2012.05.029

BARBASSA, A. P., SOBRINHA, L. A., \& MORUZZI, R. B. (2014). Infiltration well for local flood control: evaluation of operation and maintenance. Ambient. Constr., 14(2), 91-107.

BENINI, R. M. (2005 Scenarios of urban occupation and its hydrologic impacts in the Mineirinho river basin. M.Sc. Dissertation. School of Engineering at São Carlos, University of São Paulo, São Carlos, Brazil..

BRATIERES, K., FLETCHER, T. D., DELETIC, A., \& ZINGER, Y. (2008). Nutrient and sediment removal by stormwater biofilters: A large-scale design optimisation study. Water Research, 42(14), 3930-3940. http://doi.org/10.1016/j.watres.2008.06.009

CHAHAL, M. K., SHI, Z., \& FLURY, M. (2016). Nutrient leaching and copper speciation in compost-amended bioretention systems. Science of the Total Environment, 556, 302309. http://doi.org/10.1016/j.scitotenv.2016.02.125

COLSON, A. J. B. (2010). Land: its Occupation, Management, Use and Conceptualization. The Case of the Akawaio and Arekuna of the Upper Mazaruni District, Guyana-By Audrey J Butt Colson. Geographical Journal, 176(4), 371-371. http://doi.org/10.1111/j.1475-4959.2010.00380.x

CONAMA, Resolution. 357, de March, 17, 2005. National Environment -CONAMA, v. 357, 2005.

DOKULIL, M. T. (2015). Climate impacts on ecohydrological processes in aquatic systems. Ecohydrology and Hydrobiology, 16(1), 66-70. http://doi.org/10.1016/j.ecohyd.2015.08.001 
FAWB. (2009). Guidelines for filter media in biofiltration systems (Version 3.01), (June), 18.

GESSNER, M. O., HINKELMANN, R., NÜTZMANN, G., JEKEL, M., SINGER, G., LEWANDOWSKI, J., BARJENBRUCH, M. (2014). Urban water interfaces. Journal of Hydrology, 514, 226-232. http://doi.org/10.1016/j.jhydrol.2014.04.021

GELDOF, G. (1995). Adaptive water management: integrated water management on the edge of chaos. Water Science and Technology. Retrieved from http://www.sciencedirect.com/science/article/pii/027312239500532R

GOEDERT, W. J., \& LACERDA, P. C. (2007). Soil Quality Under Different Uses And Native Cerrado, 1. R. Bras. Ci. Solo.099-1108.

GORDON, E., \& MEENTEMEYER, R. K. (2006). Effects of dam operation and land use on stream channel morphology and riparian vegetation.Geomorphology, 82(3), 412-429.

HATT, B. E., FLETCHER, T. D., \& DELETIC, A. (2009). Hydrologic and pollutant removal performance of stormwater biofiltration systems at the field scale. Journal of Hydrology, 365(3-4), 310-321. http://doi.org/10.1016/j.jhydrol.2008.12.001

HATT, B. E., FLETCHER, T. D., WALSH, C. J., \& TAYLOR, S. L. (2004). The influence of urban density and drainage infrastructure on the concentrations and loads of pollutants in small streams. Environmental Management, 34(1), 112-124. http://doi.org/10.1007/s00267-004-0221-8

KAWATOKO, I. E. S. (2012). Establishment of non-structural measures as tools for urban water management in school lot. M.Sc. Dissertation. School of Engineering at São Carlos, University of São Paulo, São Carlos, Brazil.

LINE, D. E., \& ASCE, M. (2011). Bioretention Outflow: Does It Mimic Nonurban Watershed Shallow Interflow?, $\quad$ (March), 274-279. http://doi.org/10.1061/(ASCE)HE.1943-5584.0000315.

LI, J., \& DAVIS, A. P. (2016). A unified look at phosphorus treatment using bioretention. Water Research, 90, 141-155. http://doi.org/10.1016/j.watres.2015.12.015

LIU, H. H. (2011). Impact of climate change on groundwater recharge in dry areas: An ecohydrology approach. Journal of Hydrology, 407(1-4), 175-183. http://doi.org/10.1016/j.jhydrol.2011.07.024

LIU, Y., TANG, W., HE, J., LIU, Y., AI, T., \& LIU, D. (2015). A land-use spatial optimization model based on genetic optimization and game theory. Computers, $\begin{array}{lllll}\text { Environment } \text { and Urban } & \text { Systems, }\end{array}$ http://doi.org/10.1016/j.compenvurbsys.2014.09.002

LUCKE, T., \& NICHOLS, P. W. B. (2015). The pollution removal and stormwater reduction performance of street-side bioretention basins after ten years in operation. Science of the Total Environment, 536, 784-792. http://doi.org/10.1016/j.scitotenv.2015.07.142

MACHADO, J. L., TORMENA, C. A., FIDALSKI, J., \& SCAPIM, C. A. (2008). Interrelationships between physical properties and the coefficients of soil water retention curve in an oxisol under different soil use. Rev. Bras. Ciênc. Solo, 32(2), 495-502. http://doi.org/10.1590/S0100-06832008000200004

MARTIN-MIKLE, C. J., BEURS, K. M. DE, JULIAN, J. P., \& MAYER, P. M. (2015). Landscape and Urban Planning Identifying priority sites for low impact development ( LID ) in a mixed-use watershed. Landscape and Urban Planning, 140, 29-41. http://doi.org/10.1016/j.landurbplan.2015.04.002

MCCLEARY, R. J., \& HASSAN, M. A. (2008). Predictive modeling and spatial mapping of fish distributions in small streams of the Canadian Rocky Mountain foothills. Canadian Journal of Fisheries and Aquatic Sciences, 65(2), 319-333. http://doi.org/10.1139/f07161 
MUllane, J. M., FlURY, M., IQBAL, H., FREEZE, P. M., HINMAN, C., COGGER, C. G., \& SHI, Z. (2015). Intermittent rainstorms cause pulses of nitrogen, phosphorus, and copper in leachate from compost in bioretention systems. Science of the Total Environment, 537, 294-303. http://doi.org/10.1016/j.scitotenv.2015.07.157

NEGRÃO, A. C. (2015). One-dimensional hydrodynamic modeling of flood wave passage in an urban stream considering transcritical flow.. M.Sc. Dissertation. School of Engineering at São Carlos, University of São Paulo, São Carlos, Brazil.

O’DRISCOLL, M. A., SOBAN, J. R., \& LECCE, S. A. (2009). Stream Channel Enlargement Response to Urban Land Cover in Small Coastal Plain Watersheds, North Carolina. Physical Geography, 30(6), 528-555. http://doi.org/10.2747/0272-3646.30.6.528

POMPÊO, C. A. (2000). Sustainable Urban Drainage. Brazilian Journal of Water Resources. Rio Grande do Sul.

PUSP-SC - PREFEITURA DO CAMPUS USP DE SÃO CARLOS. Source: (http://www.puspsc.usp.br/ins_campus2.htm\#2) acesso em: 22/07/2015.

ZALEWSKI, M. (2002). Ecohydrology - the use of ecological and hydrological processes for sustainable management of water resources / Ecohydrologie-la prise en compte de processus écologiques et hydrologiques pour la gestion durable des ressources en eau. Hydrological Sciences Journal, 87(5), 823-832. http://doi.org/10.1080/02626660209492986

ZALEWSKI, M. (2000). Ecohydrology - the scientific background to use ecosystem properties as management tools toward sustainability of water resources. Ecological Engineering, 16, 1-8. http://doi.org/10.1016/S0925-8574(00)00071-9

ZALEWSKI, M., MCCLAIN, M., \& ESLAMIAN, S. (2016). New challenges and dimensions of Ecohydrology - Enhancement of catchments sustainability potential. Ecohydrology and Hydrobiology, 16(1), 1-3. http://doi.org/10.1016/j.ecohyd.2016.01.001

SAMPLE, D., LUCAS, W.L., JANESKI, T., ROSEEN, R.M., POWERS, D., FREEBORN, J., AND FOX, L.J., 2014. Greening Richmond, USA: a sustainable urban drainage demonstration project, P. I. Civil Eng., 167 (2), pp. 88-95, doi: 10.1680/cien.13.00036.

SÃO PAULO (city). Municipal Department of Urban Development. Drainage Manual and Stormwater Management: management of urban drainage system. São Paulo: SMDU, 2012. <http://www.habisp.inf.br/>

SILVA, L. A., \& NAZARENO, N. D. (2009). Análise do padrão de exatidão cartográfica da imagem do Google Earth tendo como área de estudo a imagem da cidade de Goiânia. Simpósio Brasileiro de Sensoriamento Remoto (SBSR), 14, 1723-1730.

UNITED STATES. SOIL CONSERVATION SERVICE. (1972).SCS national engineering handbook, section 4: hydrology. The Service.

VASCONCELOS, A. F. (2008). Análise da qualidade da água pluvial para sistemas de aproveitamento com separadores automáticos.

WENGER, S. J., ROY, A. H., JACKSON, C. R., BERNHARDT, E. S., CARTER, T. L., FILOSO, S., ... WALSH, C. J. (2009). Twenty-six key research questions in urban stream ecology: an assessment of the state of the science. Journal of the North American Benthological Society, 28(4), 1080-1098. http://doi.org/10.1899/08-186.1

WINSTON, R. J., HUNT, W. F., KENNEDY, S. G., MERRIMAN, L. S., CHANDLER, J., \& BROWN, D. (2013). Evaluation of floating treatment wetlands as retrofits to existing stormwater retention ponds. Ecological Engineering, 54, 254-265. http://doi.org/10.1016/j.ecoleng.2013.01.023

ZAFFANI, A. G. (2012). Diffuse Pollution from Urban Drainage based on ecohydrology: Diagnosis and Long Term Scenarios in Urban Watershed in São Carlos, SP. M.Sc. Dissertation. School of Engineering at São Carlos, University of São Paulo, São Carlos, Brazil. 


\title{
5. USING PCSWMM TO EVALUATE THE EFFICIENCY OF A BRAZILIAN MODULAR BIORETENTION DESIGN FOR STORMWATER TREATMENT
}

\begin{abstract}
Bioretention is a low impact development (LID) practice that has emerged as one of the best solutions for mitigating the impacts of urban development. Prior to characterizing future implementation of these systems, it is necessary to fully evaluate the efficiency of the systems already implemented. This work simulates future scenarios through quali-quantitative monitoring of a bioretention modular experimental system, which can be expanded in order to deal with an increase in output. After developing and calibrating the model, It was used to simulate one recent (2015) and three future (2025, 2050 and 2100) scenarios, based on the LID modular design proposed and on the changes in impervious area over the years. This evaluation can be assisted by the use of a numerical model, in this case the Storm Water Management Model (SWMM). This model was used to characterize the hydrology and water quality of an upstream subcatchment and downstream bioretention system in São Carlos, Brazil. The chosen area has recurrent flooding and water runoff quality issues. The model was calibrated with data from rainfall events that occurred on August and September 2015. The 2015 scenario presented the highest quality and quantity efficiency, with an average of 90,9 and 91,2\% respectively, and in 2025 with the same parameter, the lowest numbers with, 81,8 and $82,3 \%$. As the results by simulations suggest, the modular sizing methods are sufficient to maintain the performance until 2100 , with a simulated quantity efficiency of 85,1 and $89,2 \%$ for quality efficiency. The study shows how modular bioretention is an efficiency system for treat diffuse pollution in urban areas.
\end{abstract}

Keywords: urban drainage, stormwater, quali-quantitative efficiency, modelling.

\subsection{Introduction}

As the world's population grows, urban areas have grown even faster. According to the United Nations (2014), approximately 54\% of the world population currently lives in urban areas, which will likely rise to $66 \%$ by 2050 . Urban development to accommodate this population results in increased imperviousness, altering the natural hydrologic cycle by reducing infiltration (Elliot \& Trowsdale, 2007), depletion of evapotranspiration from removal of vegetation (Smith \& Banting, 2005), reduction of recharge and base flows because of the paving of the surface (Loc eta 1., 2015), and an increase in runoff volume and peak flows (Lucas and Sample 2015). Due to the direct connection between urban impervious areas and the drainage system, the increased frequency and magnitude of runoff is directly conveyed to some receiving water bodies without attenuation, shortening, because of that, the time period to the peak (Sabouri et al., 2013). In addition, pollutants are now washed off more easily and quickly (Alberti et al., 2007). Streams degrade rapidly as they accommodate the 
new flows and pollutant loads, causing a general decline in aquatic health (Kaushal \& Belt, 2012).

These widespread impacts from urban development can be mitigated by Best Management Practices - BMPs, that restore natural conditions by increasing infiltration, reducing runoff and improving water quality in runoff (Tillinghast \& Jennings, 2011; Mangangka et al., 2014; LaBarre et al., 2015; Ghodsi et al., 2016). Houdeshel et al., 2015; Ghodsi et al., 2016; Palanisamy \& Chui, 2015; and Lim \& Lu, 2016 suggest that runoff should be viewed as a resource, transforming it from a waste product through reuse, thus creating a more sustainable development practice. These mitigation techniques are collectively known as Low Impact Development (LID). In addition to runoff reduction, implementing LID may reduce flooding (Klenzendorf et al., 2015), conserve water supplies (Pongmala et al., 2015) and reduce urban heat islands that are now becoming prevalent in many cities (Loc et al., 2015).

Bioretention cells are shallow depressions filled with a filtration media and resistant drought, but with a hydrophilic vegetation. Their main purpose is to reduce runoff volume through infiltration into surrounding soils, attenuating peak flows through available storage and improving discharge water quality through filtration (Smith \& Banting, 2005; Liu et al., 2012; Lucas \& Sample, 2015). The extent of these benefits depends on some hydraulic and hydrologic factors of the upstream subcatchment and bioretention design.

The urban center of São Carlos, (the location of this study), currently experiences a higher flood frequency, due to urbanization and discontinuities in the drainage system. Imperviousness in the city varies from $55 \%$ to $100 \%$, with resulting curve numbers $(\mathrm{CN})$ from 58 to 95 (Zaffani, 2012). The Mineirinho's River, which accounts for $40 \%$ of supply from São Carlos, experiencing significant flooding as well as poor water quality.

To explore the benefits of implementing LID practices to remediate drainage and water quality issues in São Carlos, a bioretention system was installed in Campus 2 of University São Paulo, in an area experiencing high runoff peak flows. In order to evaluate this system, understanding the influence of the hydraulic and hydrological factors of the upstream subcatchment and the bioretention cell on treatment performance is needed (Mangangka et al., 2014; Sample et al., 2012). A computational model provides a tool to accomplish this goal, because of its ability to generalize system behavior and explore variations in design and other spatial and temporal factors (Smith \& Banting, 2004; Sample \& Liu, 2014). The NorthAmerican EPA's Storm Water Management Model or SWMM (Rossman, 2014) is a broad computational model for water quality and quantity analysis of urban drainage (Loc et al., 
2015; Sample et al., 2012). This model was chosen for simulating the deployed bioretention system and its upstream subcatchment due to its high spatial and temporal resolution, and its explicit hydraulic simulation of channels and pipes (Talbot et al., 2016). SWMM simulates rainfall-runoff response of a watershed, given precipitation and other meteorologial inputs and predicts the quantity and quality of the runoff (Sovan et al., 2015; Smith \& Banting, 2004).

The objective of this study is to evaluate the impacts of urban development in the flow during storm events and verify the effectiveness of a bioretention project in particular, and to generally assess LID application through computer modeling, evaluating interference the bioretention technique on both the quality and quantity of the drained water.

\subsection{Materials and Methods}

\subsubsection{Study area}

The area of study comprises the campus 2 of University of São Paulo, in São Carlos, Brazil, which is approximately 102,4 ha, and is located approximately $203 \mathrm{~km}$ in the centraleastern region of São Paulo state. (Figure 5.1). About 30\% of the area surrounding the campus is classified as environmental protected area. The region is a tributary of the Mineirinho River, whose length is approximately $4 \mathrm{~km}$, surrounded by native vegetation, forest areas and urban areas.

The region incorporates $86 \%$ of the permanent preservation area and $14 \%$ of the protection area. Rapid growth of the campus has caused deficiencies in the drainage system, resulting in floods and erosion of stream channels and streambanks. The subject bioretention has a contributing drainage area of 2,3ha, and covers $63 \mathrm{~m}^{2}$.

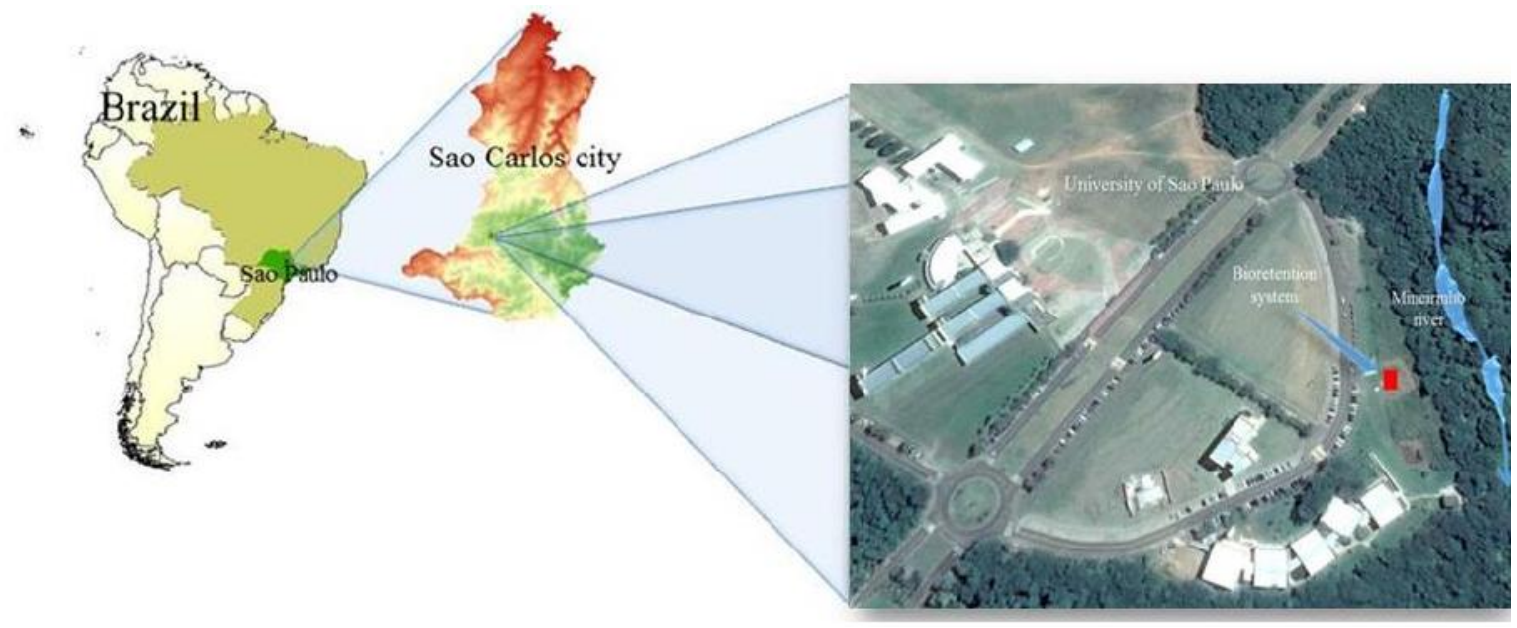

Figure 5.1 - Location of the study area. 


\subsubsection{Used Data}

The hydraulic components of the upstream subcatchment and bioretention system, (e.g., Manning's roughness coefficient, hydraulic width, slope, inverts, etc.) were estimated according to a site survey and Geographic Information System (GIS) analysis of spatial data. Hydro meteorological data included precipitation and temperature. Precipitation was measured by two rain gauges on the campus. The data were verified for homogeneity using a double mass verification method, which compared stations operated by the National Institute of Meteorology (INMET) with those from the National Center for Monitoring and Warning Natural Disasters (CEMADEN). Other meteorological data collected included wind, atmospheric pressure and temperature from the Center of Weather Forecasting and Climate Studies (CPTEC/INPE).

Water quality samples were taken based upon the methodology proposed by Macedo et al. (2015). Sample were collected from fixed locations, and were made by an automatic sampler at the entrance of the bioretention system and manually in all other points. Collected samples were analyzed in a laboratory for nitrogen, in form of nitrate and nitrite, chemical oxygen demand (COD), phosphate, iron, zinc, cadmium, lead and nickel using the analytical method recommended by Standard Methods (APHA, 1999). Table 5.1 shows the collection scheme performed for the qualitative data.

\begin{tabular}{|c|c|c|c|c|c|c|c|c|c|c|c|}
\hline \multirow[b]{3}{*}{ Date } & \multicolumn{4}{|c|}{ Before the event } & \multicolumn{7}{|c|}{ During the event } \\
\hline & \multirow{2}{*}{$\begin{array}{l}\text { Antecedent } \\
\text { dry days }\end{array}$} & \multirow{2}{*}{$\begin{array}{l}\text { Accumulated } \\
\text { precipitation } \\
\text { between events } \\
(\mathrm{mm})\end{array}$} & \multirow{2}{*}{$\begin{array}{c}\text { API } \\
30 \\
(\mathrm{~mm})\end{array}$} & \multirow{2}{*}{$\begin{array}{l}\text { API } 5 \\
(\mathrm{~mm})\end{array}$} & \multicolumn{4}{|c|}{ Time start /end } & \multirow{2}{*}{$\begin{array}{c}\text { Total } \\
\text { precipitation } \\
\text { before } \\
\text { sampling }(\mathrm{mm})\end{array}$} & \multirow{2}{*}{$\begin{array}{l}\text { Event total } \\
\text { precipitation } \\
(\mathrm{mm})\end{array}$} & \multirow{2}{*}{$\begin{array}{c}\text { Average } \\
\text { precipitation } \\
\text { intensity } \\
(\mathrm{mm} / \mathrm{h})\end{array}$} \\
\hline & & & & & & infall & Sam & pling & & & \\
\hline 25/ago & 29 & 0 & 0 & 0 & $9 \mathrm{~h} 42$ & $14 \mathrm{~h} 17$ & 10h04 & $10 \mathrm{~h} 50$ & 3.8 & 5.8 & 1.26 \\
\hline 27/ago & 1 & 6.8 & 3.6 & 3.6 & $14 \mathrm{~h} 53$ & $17 \mathrm{~h} 47$ & $15 \mathrm{~h} 28$ & $17 \mathrm{~h} 28$ & 2.4 & 2.6 & 0.89 \\
\hline 08/set & 0 & 31.2 & 31.2 & 30.3 & $15 \mathrm{~h} 59$ & $\begin{array}{c}1 \mathrm{~h} 55 \\
\text { (next day) }\end{array}$ & $16 \mathrm{~h} 03$ & $17 \mathrm{~h} 59$ & 29 & 39 & 3.93 \\
\hline
\end{tabular}

Table 5.1 - Samplings performed by rainfall event for qualitative data.

\subsubsection{Hydrological model}

A SWMM model was developed based on the drainage area characteristics, types of soil, imperviousness, among other aspects. The USEPA Storm Water Management Model (SWMM) is a computer program that computes dynamic rainfall-runoff for single event and long-term (continuous or period-of-record) runoff quantity and quality from developed urban and undeveloped or rural areas. The runoff component of SWMM operates on a collection of subcatchment areas that receive precipitation and generate runoff and pollutant loads. The 
routing portion of SWMM transports this runoff overland and underground through a system of pipes, channels, storage and treatment devices, pumps and regulators. SWMM tracks the quantity and quality of runoff generated within each subcatchment and the flow rate, flow depth and quality of water in each pipe and channel during a simulation period comprised of multiple time steps. The Figure 5.2 show a flowchart modeling with PCSWMM.

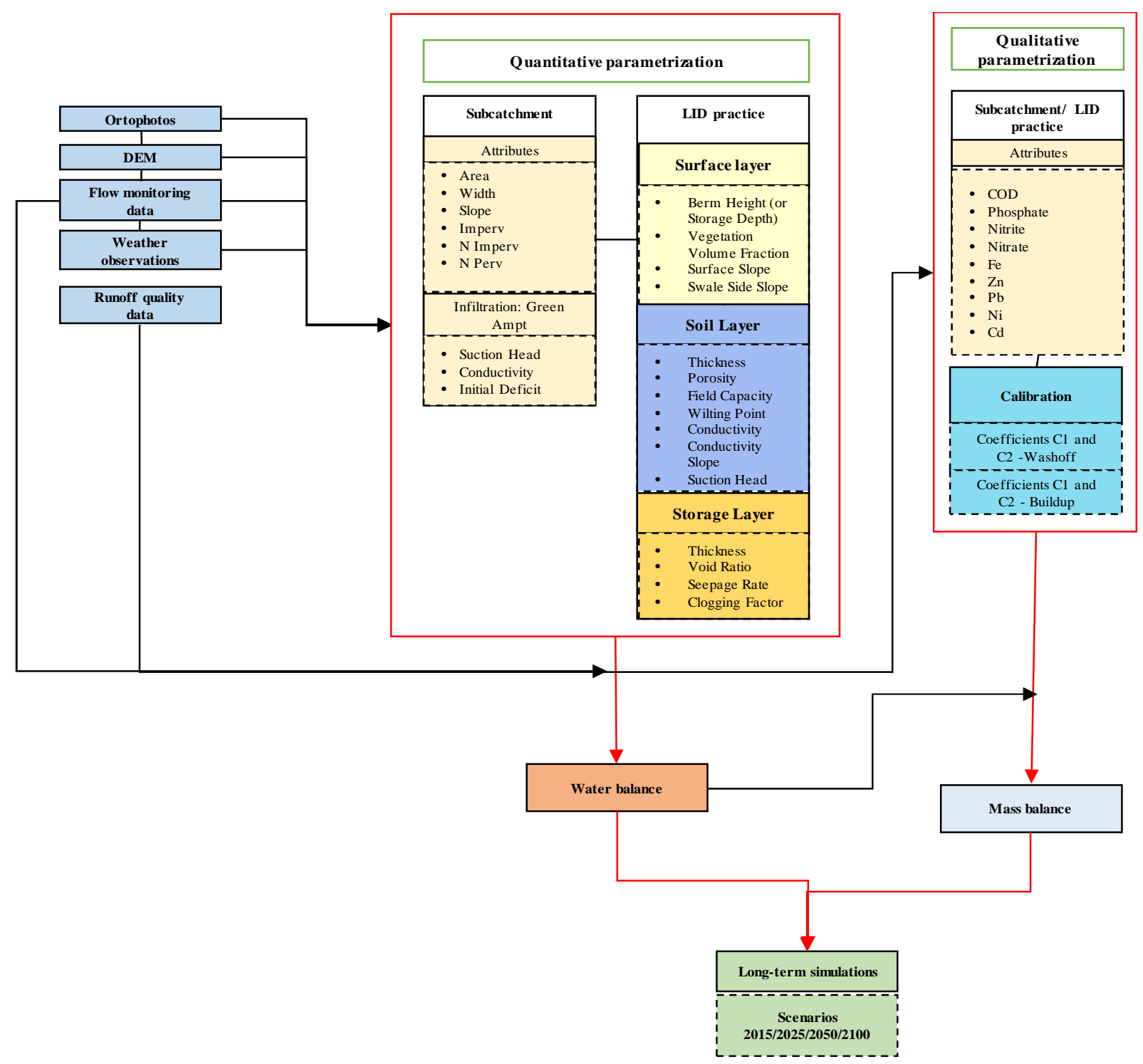

Figure 5.2 - Flowchart of the methodological steps of the research in PCSWMM.

A digital elevation model (DEM) was developed based on satellite image. DEM and an aerial photography with $1 \mathrm{~m}$ and $0,2 \mathrm{~m}$ horizontal resolution, respectively, were used as a data sources. Hydraulic features were confirmed through field inspection. Based on the analysis of GIS data and aerial images, the surface was classified as either buildings (roof), footpaths paved, roadway, parking lots and permeable areas. 
Each of these areas was then analyzed for their hydraulic and hydrological parameters. After manipulating the storage behavior, according to the rules defined by the theories used in the model elaboration (James, 1985), the tool gives temporary results to be reintroduced into the SWMM for hydraulic analysis. The areas were delineated into two subcatchments, i.e., the bioretention area and its contributing drainage area, which was determined to be $75 \%$ impervious by analysis of GIS data.

SWMM version 5.1.010 includes an LID computational model which simulates the hydrological response of each practice as part of its respective subcatchment. SWMM allows runoff to be routed from impervious to pervious areas, and takes the additional infiltration into account. Within the bioretention submodel, a report provides key characteristics such as water level, soil moisture, evaporation, infiltration, soil percolation, runoff and continuity error of the bioretention system. The model scheme can be observed in Figure 5.3.

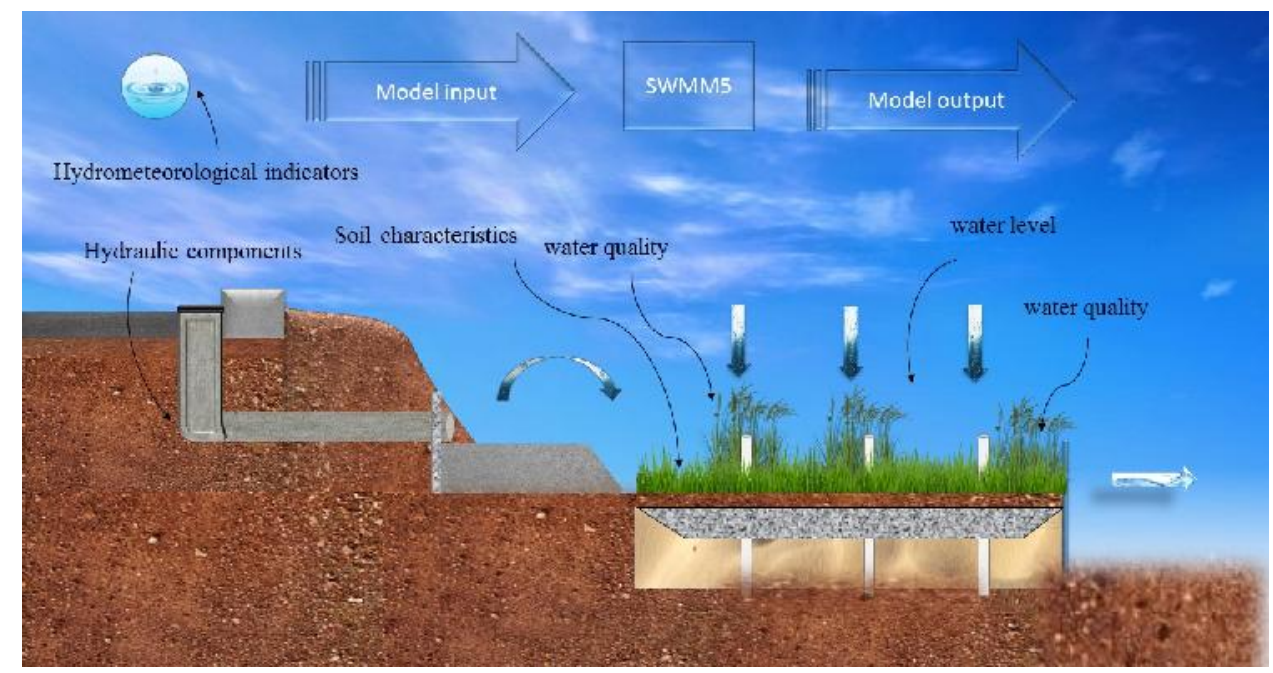

Figure 5.3 - Model building scheme based on real scenario data.

\subsubsection{Model calibration and validation}

Model calibration provides means of verifying the model with respect to observed physical scenarios. Monitoring the discharge into and out of the bioretention and the water quality for selective rain events was performed. Calibration was done using a sensitivity analysis by the Sensitivity-based Radio Tuning Calibration (SRTC) tool in PCSWMM version 6.3 (CHI, 2007).

Water quantity calibration was performed using monitored events from August to September, 2015. The parameters used for calibration were the contributing area, hydraulic width, average slope and the imperviousness. These parameters were chosen based on the 
sensitivity analysis known in literature (e.g. Dudula, J., \& Randhir, T., 2016). The SRTC allows the user to define the uncertainty associated with the parameters and to execute the model multiple times within the uncertainty limits. Once completed, adjustments were made to individual parameters manually without the pre-defined uncertainty intervals, using the observed data and the model response. The model performance was evaluated by the NashSutcliffe Efficiency (NSE) and the correlation coefficient $\left(\mathrm{R}^{2}\right)$.

Infiltration was compared to soil moisture sensor data, installed in the bioretention cell. The Green-Ampt method was used to calculate infiltration within each time step. Soil laboratory analysis indicated the local soils were a medium to fine sand to dark brown silt. Parameters for this type of soil were taken from Rawls, W.J. et al., (1983), and can observed the contribution area characteristics observed in Table 5.2. These parameters values were used for the calibration of the drainage area and for the bioretention system subcatchments, for more details can be found in appendix c. Manning's coefficient for the impermeable areas was estimated as 0.06 .

\begin{tabular}{|c|c|c|c|c|c|c|c|c|c|}
\hline & $\begin{array}{c}\text { Area } \\
\text { (ha) }\end{array}$ & $\begin{array}{c}\text { Width } \\
(\mathrm{m})\end{array}$ & $\begin{array}{c}\text { Slope } \\
(\%)\end{array}$ & $\begin{array}{c}\text { Imperv. } \\
(\%)\end{array}$ & $\begin{array}{c}\mathrm{N} \\
\text { Imperv }\end{array}$ & $\begin{array}{c}\mathrm{N} \\
\text { Perv } \\
\end{array}$ & $\begin{array}{c}\text { Suction Head } \\
(\mathrm{mm})\end{array}$ & $\begin{array}{c}\text { Conductivity } \\
(\mathrm{mm} / \mathrm{hr})\end{array}$ & $\begin{array}{c}\text { Initial Deficit } \\
\text { (frac.) }\end{array}$ \\
\hline \multicolumn{10}{|l|}{ Subcatchments } \\
\hline Contr. Area & 2,37 & 240 & 3 & 85 & 0,05 & 0,3 & 170 & 6 & 0,6 \\
\hline
\end{tabular}

Table 5.2 - Simulation parameters.

Water quality calibration used data obtained from storm event on August and September, 2015. To find the wash off coefficients a plot of load (mg. $\left.\mathrm{s}^{-1}\right)$ versus flow $\left(\mathrm{L} . \mathrm{s}^{-1}\right)$ was made for each parameter to be analyzed and then a power equation for the curve adjustments were determined from least squares analysis, resulting in the wash off coefficient (C1) and the wash off exponent (C2) to be used in the Rating Curve. Table 5.3 shows the $\mathrm{C} 1$ and $\mathrm{C} 2$ coefficients, and the $\mathrm{R}^{2}$ for the adjustment of each parameter. The plotted graphs, for each parameter, can be seen in the appendix. Fourteen points were considered to the entrance regression and five to the outflow regression.

The wash off calibration is representative as indicated by the $\mathrm{R}^{2}$, with the exception of Fe. The low adjustment efficiency for iron can be explained by the erosion that occurred in the area during the monitored events. 


\begin{tabular}{|c|c|c|c|c|c|c|}
\hline \multirow{3}{*}{ Parameter } & \multicolumn{3}{|c|}{ In } & \multicolumn{3}{|c|}{ Out } \\
\hline & $\mathrm{kg} / \mathrm{m}^{3}$ & & & $\mathrm{~kg} / \mathrm{m}^{3}$ & & \\
\hline & $\mathrm{C} 1$ & $\mathrm{C} 2$ & $\mathrm{R}^{2}$ & $\mathrm{C} 1$ & $\mathrm{C} 2$ & $\mathrm{R}^{2}$ \\
\hline COD & 41,58 & 0,5981 & 0,87 & 16,98 & 0,87 & 0,99 \\
\hline Phosphate & 0,12 & 0,8397 & 0,98 & 0,11 & 0,87 & 0,98 \\
\hline Nitrite & 0,02 & 0,8257 & 0,95 & 0,0098 & 0,88 & 0,99 \\
\hline Nitrate & 1,75 & 0,388 & 0,89 & 1,33 & 0,5 & 0,96 \\
\hline $\mathrm{Fe}$ & 15,51 & 0,0071 & 0,0002 & 3,3 & 0,74 & 0,85 \\
\hline $\mathrm{Zn}$ & 0,18 & 0,8367 & 0,95 & 0,1 & 0,96 & 1 \\
\hline $\mathrm{Cd}$ & 0,03 & 1,2133 & 0,95 & 0,043 & 1,19 & 0,99 \\
\hline $\mathrm{Pb}$ & 0,03 & 1,2045 & 0,89 & 0,024 & 1,22 & 0,99 \\
\hline $\mathrm{Ni}$ & 0,07 & 0,9581 & 0,99 & 0,0998 & 1,02 & 1 \\
\hline
\end{tabular}

Table 5.3 - Values of calibration coefficients for pollution concentrations in the wash water (Washoff)

For the buildup calibration, the data acquired from event 1 was used, since it is the only monitored event preceded by dry days (29 in total). The buildup EXP function was used for this calibration, requiring two coefficients, $\mathrm{C} 1$ and $\mathrm{C} 2$, to be calculated. The $\mathrm{C} 1$, or maximum accumulation constant, was calculated through the total income mass ( $\mathrm{kg})$, divided by the contribution area (ha). The accumulation constant (C2) is the inverse of the number of dry days. The $\mathrm{C} 1$ and $\mathrm{C} 2$ were used in the EXP function for Buildup and are shown in Table 5.4. The Buildup coefficients were adjusted according to the methodology proposed by (Alvarez 2010, Zaffani, 2012) and are shown in Table5.4.

\begin{tabular}{lrr}
\hline & $\mathrm{C} 1$ & $\mathrm{C} 2$ \\
$\mathrm{COD}$ & $\mathrm{kg} / \mathrm{ha}$ & $1 / \mathrm{dia}$ \\
\hline Phosphate & 0,20466 & 0,04 \\
Nitrite & 0,00072 & 0,04 \\
$\mathrm{Nitrate}$ & 0,00005 & 0,04 \\
$\mathrm{Fe}$ & 0,00824 & 0,04 \\
$\mathrm{Zn}$ & 0,08596 & 0,04 \\
$\mathrm{~Pb}$ & 0,00079 & 0,04 \\
$\mathrm{Ni}$ & 0,00028 & 0,04 \\
$\mathrm{Cd}$ & 0,00038 & 0,04 \\
\cline { 2 - 3 } Table 5.4 - Values of calibration coefficients for pollution accumulation concentrations (Buildup)
\end{tabular}

Pollutant accumulation on urban impermeable surfaces, such as roads, sidewalks and rooftops during dry periods is referred as build-up pollutant. The accumulated pollutants wash off load varies according to the deposition rates, the duration of prior drought period and the effects of redistribution over the drought of the previous period. However, due to different results coming out of different investigation studies, researchers began to question the relationship between pollutant accumulation versus deposition speed over the prior drought period (Chiew et al, 1999). The influence of many other factors, such as land use, traffic 
volume and weather, play different roles over the accumulation of different pollutants (Egodawatta and Goonetilleke, 2006).

\subsubsection{Future scenarios}

Scenarios were created for the model runs, as the years 2015, 2025, 2050, and 2100, considering the possible evolution of the population and land use within the area and the need to augment the bioretention dimensions. The dimensions of the bioretention system and the percentage of impermeable areas of each scenario are shown in Table 5.5.

These values were obtained using the sizing method and simulation developed by Rosa et al. (submitted) and presented in Rosa et al. (2015) and Rosa et al. (2016). In this methodology, the following parameters have to be considered for the calculation: hydrological risk, rainfall intensity, contributing drainage area, soil properties, precipitation, runoff coefficient, drained peak flow, stored volume, bioretention geometry, mass reduction, inflows, spillway and infiltration outflows, pollution load, reductions in inflows and discharges and PULS routing method. To facilitate design of a bioretention cell, a computational model was developed to simulate and optimize its design, using unique parameters to each cell given its specific location. A key feature of the method is that it estimates the eventual size of the bioretention cell for multiple, cumulative scenarios. This allows the designer to select a variety of trial sizes and iteratively simulate each bioretention cell by steps, by setting the desired time intervals and the input parameters.

\begin{tabular}{ccccc}
\hline Year & Width $(\mathrm{m})$ & Length $(\mathrm{m})$ & Area $\left(\mathrm{m}^{2}\right)$ & Occupation $(\%)$ \\
\hline 2015 & 5,6 & 10,9 & 63 & 25 \\
2025 & 5,6 & 13 & 72,8 & 50 \\
2050 & 5,6 & 21 & 117,6 & 75 \\
2100 & 5,6 & 25 & 140 & 85 \\
\hline
\end{tabular}

Table 5.5 - Dimensions of bioretention techniques for future scenarios.

For the qualitative simulation, the pollutants concentration in rainwater should be inserted, which was obtained from Galavoti (2010) shown in Table 5.6.

\begin{tabular}{cc}
\hline Parameters & Concentration $(\mathrm{mg} / \mathrm{l})$ \\
\hline BOD & 15,00 \\
Phosphate & 0,07 \\
Nitrite & 0,09 \\
Nitrate & 0,01 \\
$\mathrm{Fe}$ & 0,11 \\
$\mathrm{Zn}$ & 0,33 \\
$\mathrm{~Pb}$ & 0,05 \\
$\mathrm{Ni}$ & 0,02 \\
$\mathrm{Cd}$ & 0,02 \\
\hline
\end{tabular}

Table 5.6 - Rain concentration Galavoti according to method (2010) 


\subsection{Results and discussion}

\subsubsection{PCSWMM Calibration and validation}

The three rainfall events quantity calibration, by the SRTC tool, is provided in Figure 5.4. The three events were calibrated simultaneously, achieving a NSE of 0,64 and $R^{2}$ of 0,66 for the entrance, and a NSE of 0,79 and a $\mathrm{R}^{2}$ of 0,83 for the exit. In general, NSE and $\mathrm{R}^{2}$ higher than 0,5 are considered satisfactory for model calibration (Moriasi et al., 2007). Based upon these results, the calibration in PCSWMM, with the SRTC has shown to be reasonably capable of predicting runoff within this study.

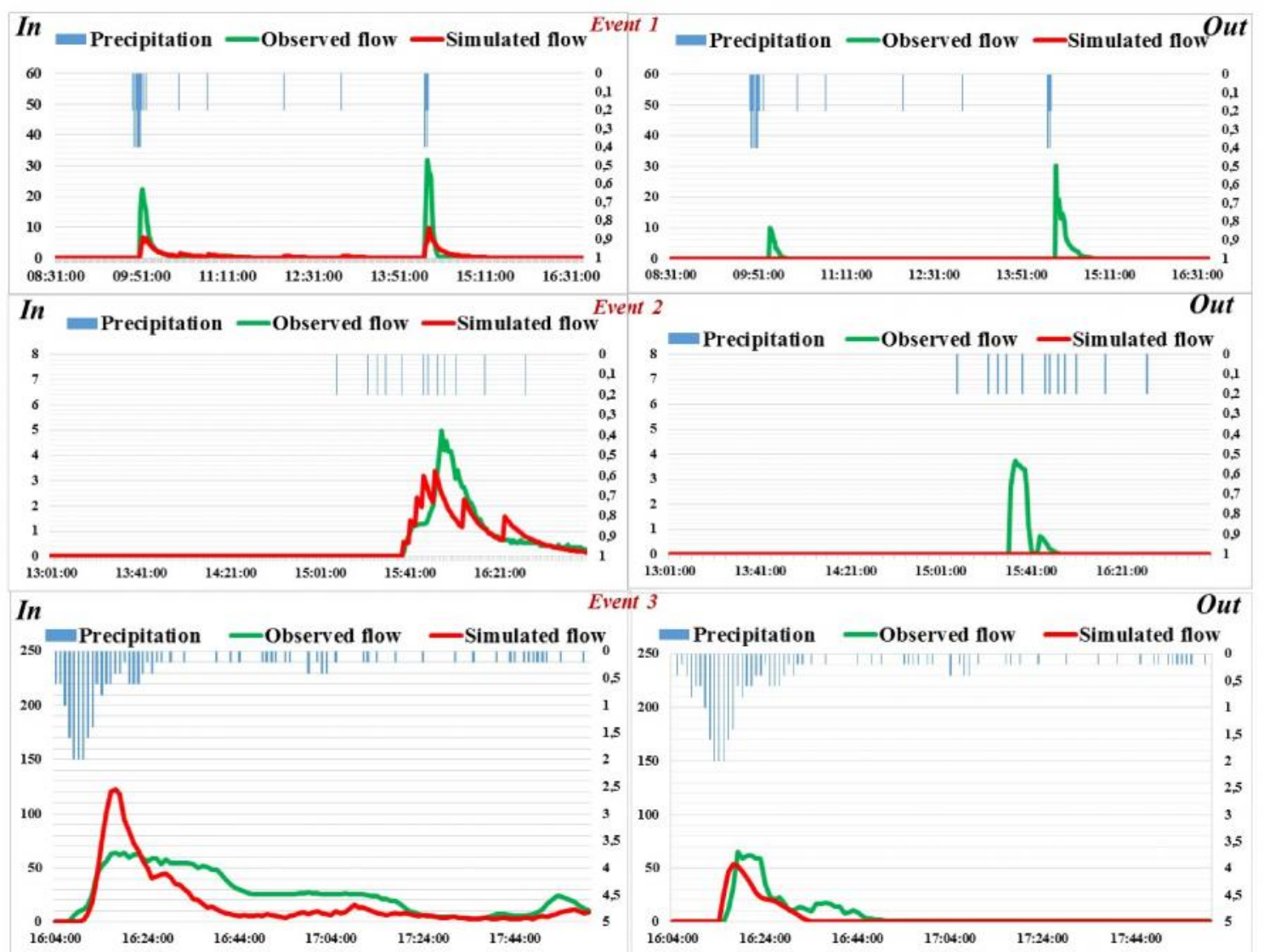

Figure 5.4 - Results for calibration based on rain-flow profile in bioretention technique of entry for each rainfall event

\subsubsection{Future scenarios Simulation}

This research considers the simulation of future scenarios for the expansion of land use and occupation to evaluate the integrated efficiency of the bioretention technique, for quality and quantity control of the urban runoff. In the following items, we present the results generated by PCSWMM's simulations. 


\subsubsection{Quantitative efficiency}

Table 5.7 provides inlet, outlet and the infiltrated runoff volumes for the years of 2015, 2025, 2050 and 2100. The simulation results indicated that the predicted runoff reduction will reduce from present day to 2025. However, it will increase in the following simulated years. Considering this, the planned adaptations in the bioretention, for the changes in the contribution area, may be beneficial.

\begin{tabular}{lcccc}
\hline & \multicolumn{4}{c}{ Volume in Millions of liters } \\
\cline { 3 - 5 } Inlet & 2015 & 2025 & 2050 & 2100 \\
\cline { 3 - 5 } Outlet & 8,8 & 17,4 & 25,9 & 29,5 \\
Stored volume & 0,8 & 3,2 & 4,1 & 4,2 \\
\hline Efficiency \% & 8 & 14,2 & 21,9 & 25,1 \\
\hline & Table 5.7 - Input volumes, output, and infiltration to the simulated scenarios
\end{tabular}

The design and simulate a bioretention cell is proposed by Rosa et al. (submitted). Thus, it was developed a computational model in VBA (Visual Basic for Applications), the model called BIRENICE (BIoREteNtIon CEll method). A key feature of the method is to estimate the eventual size of the bioretention cell for multiple, cumulative scenarios. This enables the designer to select a variety of trial sizes and iteratively simulate each bioretention cells in steps, by setting the desired time intervals and the input parameters.

This proposed modular sizing aimed to keep the quantity efficiency constant through the increase of the impervious area, due the occupation over the years. However, the SWMM model differs from the BERENICE, which can alter the storage rate from the designed and the difference in efficiency over the simulated years. In addition, the sizing for the proposed efficiency was done for a rainfall intensity of $77,9 \mathrm{~mm} / \mathrm{h}$ (a $20 \mathrm{~min}$ rainfall for 5 return years) and the simulation covers different precipitations and, consequentially, different income discharges. The 2015 scenario presents the highest quantity efficiency of $90,7 \%$ and the 2025 , the lowest with $81,4 \%$. The efficiency is improved from 2025 to 2050 with $84,3 \%$ and continues to raise to 2100 , reaching $85,9 \%$.

The accumulated volume at the entrance and at the exit of the bioretention system was analyzed for each scenario. From January to April of the each scenario-year, totalizing 15 months, the historic precipitation from January 2015 to April 2016 was used (Figure 5.5). 


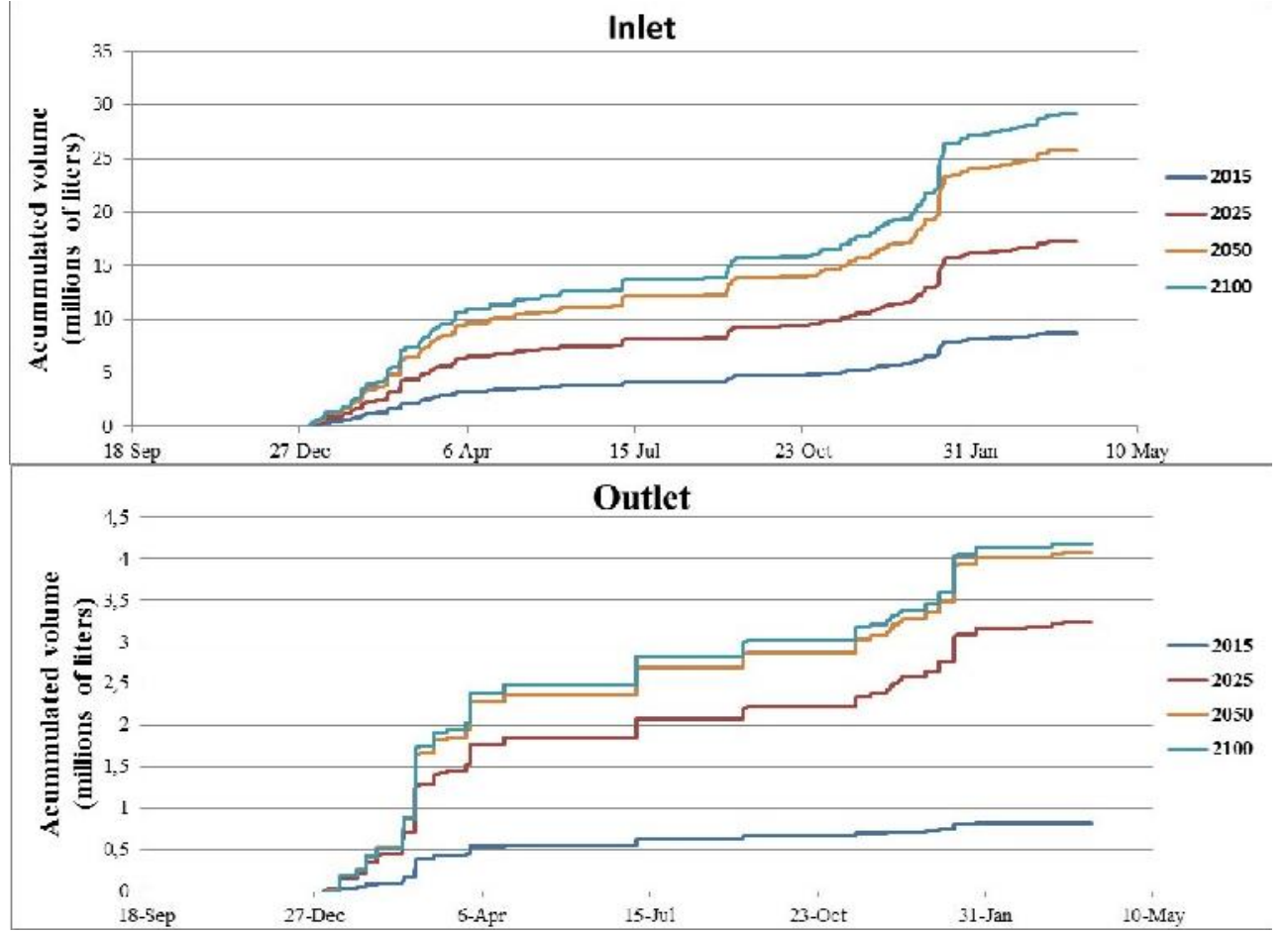

Figure 5.5 - Accumulated volume for each scenario

The accumulated volume curve behavior (Figure 5.5) reacts as expected in the dry and rainy period, with a more accentuated accumulation in the rainy months. However, for the outlet, the accumulation tends to be more uniform during the year, which suggests that bioretention provides some resilience in operating under the both weather conditions (dry or rainy).

\subsubsection{Qualitative efficiency}

The pollutant removal efficiency is directly related to the percentage of the volume of the water infiltration and exhibits similar behaviour with all constituents. It should be emphasized that the analysis was made for the total amount of precipitated rain during the day, not considering the rain duration, which can explain some differences in efficiency for near precipitated volumes values.

For a better comprehension of the bioretention removal capacity, the average removal efficiency of all pollutants was grouped into precipitation intervals in Figure 5.6, considering the same number of days in each group. The days, with precipitations lower than $10 \mathrm{~mm}$, were not considered in Figure 5.6, since it is almost $100 \%$.

Comparing the scenario of 2025 to 2100 , the nearer and farther future scenarios, it is possible to verify that the removal efficiency for smaller amounts of precipitation is greater 
for future scenarios, thanks to a greater holding capacity resulting from the increase of the total area of the technique. However, these scenarios efficiency tends to be lower with higher precipitation volumes due to the fact that with a larger percentage of impervious area, higher input flow rates compromise the ability to store larger percentages of input volume.

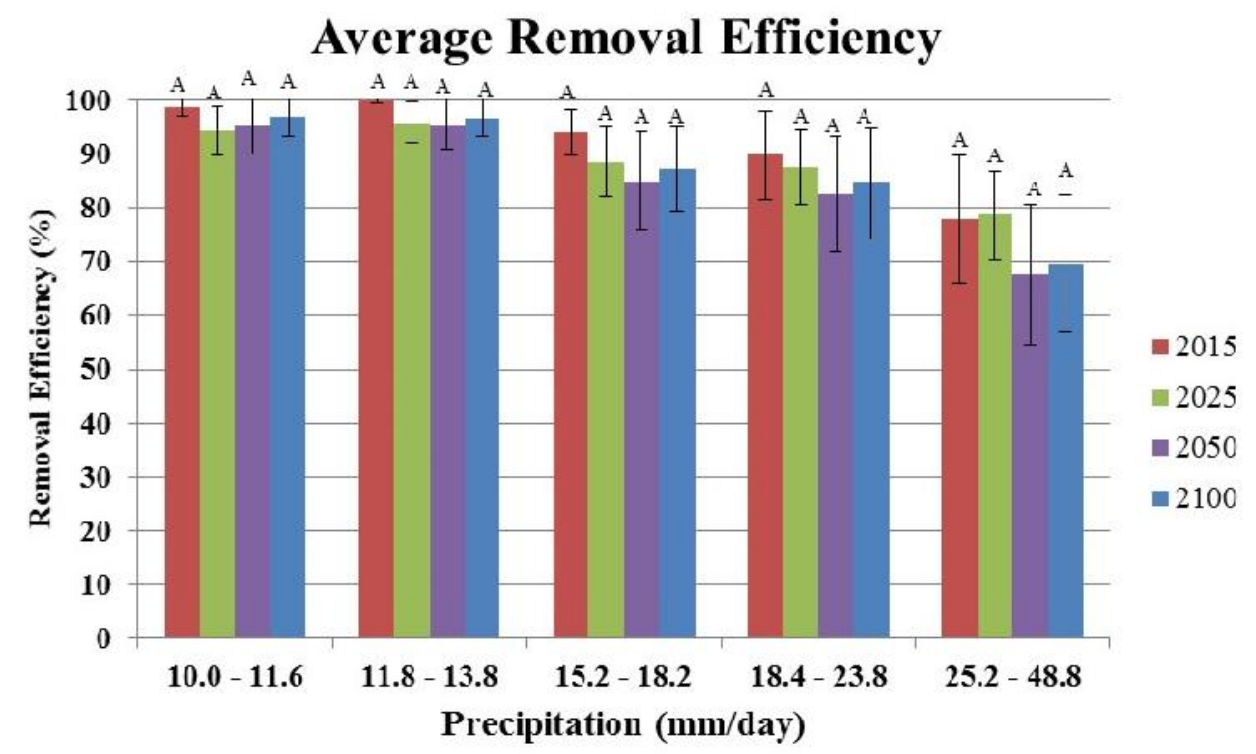

Figure 5.6 - Average removal efficiency by depth

It is possible to notice that the average bioretention removal efficiency for all scenarios keep constant. With Minitab 17 software support was performed variance analysis, the results are shown in Table 5.8. Using a significance $(\alpha)$ of 0,05 the p-value, that indicates the probability of falsely reject the null hypothesis when it is true, can be lower than or equal to significance level $(\alpha)$. The result obtained was $p=0,106$, providing evidences to conclude that scenarios average efficiencies analyzed are equal.

\begin{tabular}{lccccc}
\hline Source & GL & SQ (AJ.) & QM (Aj.) & Valor F & Valor-P \\
\hline Scenario & 3 & 1422 & 474 & 2.06 & 0.106 \\
Error & 2016 & 49616 & 229.7 & & \\
Total & 2019 & 51038 & & & \\
\hline
\end{tabular}

Table 5.8 - Variance analysis

To verify the information veracity the Tukey's method was applied with a trust interval of $95 \%$. The method expresses that averages that does not shares the same letter are significantly different. Through Table 5.9 it is assumed that all scenarios belong to group A, in other words, the analyzed efficiencies for the scenarios are very similar between each other. 


\begin{tabular}{cccc}
\hline Scenário & N & Average & Grouping \\
\hline 2015 & 55 & 91.97 & $\mathrm{~A}$ \\
2025 & 55 & 88.89 & $\mathrm{~A}$ \\
2050 & 55 & 86.89 & $\mathrm{~A}$ \\
2100 & 55 & 85.12 & $\mathrm{~A}$ \\
\hline
\end{tabular}

Table 5.9 - Grouping using Tukey's method

Through variance analysis and Tukey's test, it is possible to conclude that beyond efficiencies being similar, the precipitation intensity does not interfere on system performance.

Table 5.10 shows that the current scenario, of 2015, which has the highest simulated efficiency, between $90,0 \%$ and $94,7 \%$, dropping down on the 2025 scenario, varying from $81,3 \%$ to $86,5 \%$. For the following year, the efficiency, in general, raised compared to 2025 between $84,3 \%$ to $87,5 \%$ in 2050 and 85,8 to $88,3 \%$ in 2100 . The highest removal efficiency, in all scenarios, was for iron, contradicting the efficiency, measured in the field, in which iron presented the lowest efficiency of all parameters. That supported that the wash off quality calibration for this parameter was failed. The parameters with the lowest removal efficiency, however, varies according to the scenarios.

\begin{tabular}{|c|c|c|c|c|c|c|c|c|c|c|c|c|}
\hline & \multicolumn{3}{|c|}{2015} & \multicolumn{3}{|c|}{2025} & \multicolumn{3}{|c|}{2050} & \multicolumn{3}{|c|}{2100} \\
\hline & Inlet & Outlet & & Inlet & Outlet & & Inlet & Outlet & & Inlet & Outlet & \\
\hline & $\begin{array}{c}\text { Mass } \\
(\mathrm{kg})\end{array}$ & $\begin{array}{l}\begin{array}{l}\text { Mass } \\
(\mathrm{kg})\end{array} \\
\end{array}$ & $\begin{array}{c}\text { Effi. } \\
(\%)\end{array}$ & $\begin{array}{c}\text { Mass } \\
(\mathrm{kg})\end{array}$ & $\begin{array}{c}\text { Mass } \\
(\mathrm{kg})\end{array}$ & $\begin{array}{l}\text { Effi. } \\
(\%)\end{array}$ & $\begin{array}{c}\text { Mass } \\
(\mathrm{kg})\end{array}$ & $\begin{array}{l}\begin{array}{l}\text { Mass } \\
(\mathrm{kg})\end{array} \\
\end{array}$ & $\begin{array}{l}\text { Effi. } \\
(\%)\end{array}$ & $\begin{array}{c}\begin{array}{c}\text { Mass } \\
(\mathrm{kg})\end{array} \\
\end{array}$ & $\begin{array}{c}\text { Mass } \\
(\mathrm{kg})\end{array}$ & $\begin{array}{c}\text { Effi. } \\
(\%)\end{array}$ \\
\hline $\mathrm{Cd}$ & 0,18 & 0,02 & 91,01 & 0,35 & 0,07 & 81,43 & 0,52 & 0,08 & 84,42 & 0,59 & 0,08 & 85,86 \\
\hline COD & 134,21 & 12,35 & 90,80 & 263,03 & 48,54 & 81,54 & 390,38 & 60,94 & 84,39 & 441,00 & 62,53 & 85,82 \\
\hline $\mathrm{Fe}$ & 1,71 & 0,09 & 94,69 & 2,64 & 0,36 & 86,53 & 3,57 & 0,45 & 87,46 & 3,93 & 0,46 & 88,33 \\
\hline $\mathrm{Ni}$ & 0,62 & 0,06 & 90,66 & 1,22 & 0,23 & 81,44 & 1,82 & 0,28 & 84,37 & 2,05 & 0,29 & 85,78 \\
\hline Nitrate & 0,86 & 0,07 & 91,43 & 1,64 & 0,29 & 82,20 & 2,40 & 0,37 & 84,74 & 2,70 & 0,38 & 86,12 \\
\hline Nitrite & 0,01 & 0,00 & 90,00 & 0,02 & 0,00 & 83,33 & 0,03 & 0,00 & 85,19 & 0,03 & 0,00 & 86,67 \\
\hline $\mathrm{Pb}$ & 0,44 & 0,04 & 90,77 & 0,87 & 0,16 & 81,44 & 1,30 & 0,20 & 84,36 & 1,47 & 0,21 & 85,82 \\
\hline Phosphate & 0,63 & 0,06 & 90,72 & 1,23 & 0,23 & 81,48 & 1,82 & 0,28 & 84,40 & 2,06 & 0,29 & 85,80 \\
\hline $\mathrm{Zn}$ & 2,93 & 0,27 & 90,70 & 5,76 & 1,07 & 81,46 & 8,56 & 1,34 & 84,34 & 9,68 & 1,38 & 85,78 \\
\hline
\end{tabular}

Table 5.10 - Removal efficiency in future scenarios

In order to compare the overall quality efficiencies between the scenarios, the average for all simulated scenarios was done, shown in Figure 5.7.

It can be noticed that, from 2015 to 2025 , the proposed modulation is not sufficient to keep the same efficiency. The reason is the sudden growth of the impervious area, from $25 \%$ to $50 \%$, and, consequently, the increase of water volume into the bioretention. In the other scenarios, it can be noticed that the proposed modulation to the $\mathrm{CT}$ area increment will be enough to improve the efficiency in the following scenario. Another factor that may 
interfere with the desired efficiency is that the proposed modulation is not a linear growth that accompanies the growth of the urban area.

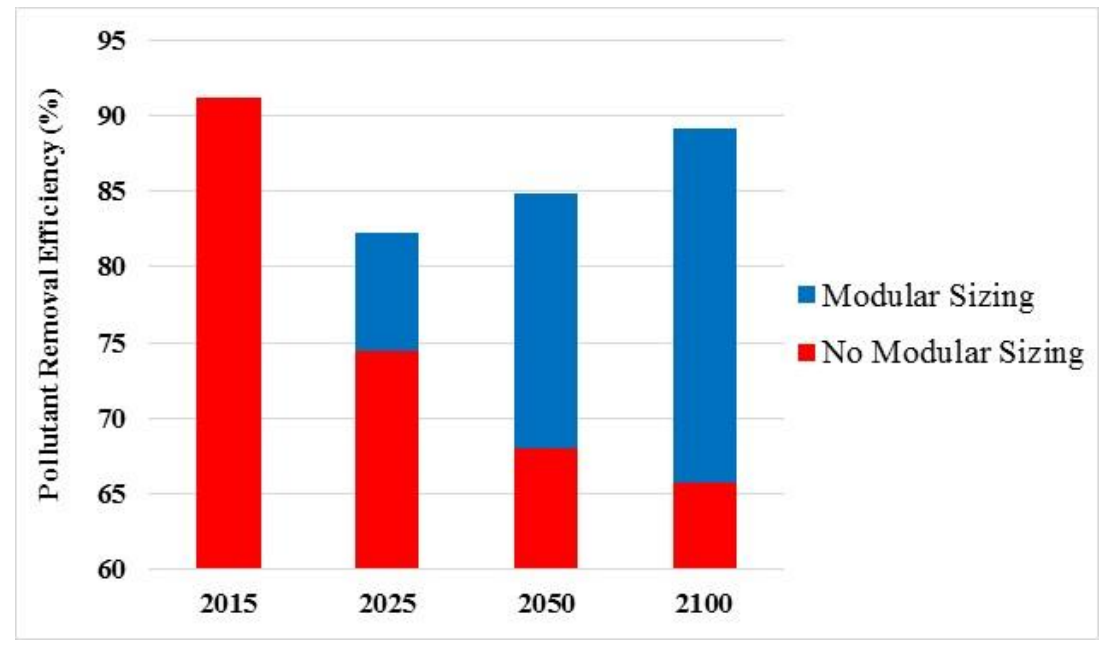

Figure 5.7 - Average Efficiency for scenarios

Comparing the quality efficiency with the quantity, in Table 5.7, it is noticeable these values proximity: 90,9 and $91,2 \%$ in $2015,81,8$ and $82,3 \%$ in $2025,84,6$ and $84,9 \%$ for 2050 ; 85,1 and $89,2 \%$ in 2100 , for quantity and quality efficiencies respectively. This comparison shows the importance of water retention for the pollutant removal rate and how the quality efficiency depends on quantity efficiency.

A research indicates a relationship between the contribution area and the area of bioretention system: WSUD Manual (MELBOURNEWATER, 2003) presented efficiency fractions of pollutant removal for bioretention system with $2 \%$ of the catchment area reaching up to $99 \%$ efficiency. The system presented here has a unique design methodology, not following the mentioned relationship, with approximately $0,3 \%$ of the drainage area. However, it has different construction characteristics, as being deeper than the commonly used with pre-treatment for solids removal and having an expansion of the modular system, allowing the achievement of the presented efficiency.

\subsection{Conclusions}

This study showed that implementing LID practices such as bioretention can mitigate the impacts of urban development, in terms of both runoff and pollution excess. Thereby, the risk of flooding in urban watersheds is reduced.

Simulations were conducted in PCSWMM in order to evaluate the expected LID practice performance over the incoming years. The quality calibration model was satisfactory, 
indicated by high NSE and $\mathrm{R}^{2}$ values, for both the subcatchment and the LID practice. The quality calibration, however, was poor, due to the data limitation.

Simulated pollutant removal efficiency for all scenarios was high, reaching values between $80 \%$ to $90 \%$, with the 2015 scenario receiving the highest efficiencies. The positive impact of increasing the size of the bioretention (on removal efficiency) appears to offset the negative impact of increasing urban development. Thus, the model has been demonstrated as an effective designing tool for evaluating the effects of LID implementation. The steps described in this study can be customized and applied to similar LID practices in various climate regimes to more generally evaluate the effectiveness of LID.

The modular sizing, as the simulation has shown, is effective in maintaining the quality efficiency until 2100. However, the LID practice area, proposed for 2025, should be reviewed by other methods, in order to improve the LID practice efficiency for the corresponding year and land use characteristics and to prevent higher pollutants load to go to the receiving water body.

Given the difficulty to determine the adjustment coefficients for the wash off and build up steps, this article wanted to elucidate these steps in order to contribute to the protocol of low-impact techniques modeling for urban drainage.

\section{Acknowledgements}

The authors acknowledge the support of projects: (1) MAPLU2 - Stormwater Management in Urban Environment/FINEP, (2) Thematic Project 2008/15161-1 FAPESP "Assessment of Impacts and Vulnerability to Climate Change in Brazil and Strategies for Adaptation Options" (3) Casadinho/PROCAD CNPq 552494/2011-9 (UFAL-EESC / USP) "Advanced monitoring of biotechnological processes and environmental quality" and (4) CNPq 307637/2012-3 of Scientific Productivity. FAPESP 2013/06611-1 Detention and Bioretention for Control of the Diffuse Pollution in the Urban Drainage: Approach Experimentaladaptation by Ecohydrologic Base.

\section{References}

AHIABLAME, L., \& SHAKYA, R. (2016). Modeling flood reduction effects of low impact development at a watershed scale. Journal of Environmental Management, 171, 81-91. http://doi.org/10.1016/j.jenvman.2016.01.036

ALBERTI, M., BOOTH, D., HILL, K., COBURN, B., AVOLIO, C., COE, S., SPIRANDELLI, D., (2007). The impact of urban patterns on aquatic ecosystems: An empirical analysis in Puget lowland sub-basins. Landscape Urban Plan. 80, 345-361.

ALVAREZ, R. P. P. (2010). Experimental and theoretical study of the water quality in urban draining based on ecohydrology. PhD Thesis. School Of Engineering At São Carlos, University Of São Paulo, São Carlos, Brazil. 
APHA, A. (1999). WPCF, Standard methods for the examination of water and wastewater. American Public Health Association/American Water Works Association/Water Environment Federation, Washington DC, USA..

BLOORCHIAN, A., BLOORCHIAN, A. A., AHIABLAME, L., OSOULI, A., \& ZHOU, J. (1800). Modeling BMP and Vegetative Cover Performance for Highway Stormwater Runoff Reduction. Procedia Engineering, 145, 1-15. http://doi.org/10.1016/j.proeng.2016.04.074

BROWN, R. A., SKAGGS, R. W., \& HUNT, W. F. (2013). Calibration and validation of DRAINMOD to model bioretention hydrology. Journal of Hydrology, 486, 430-442. http://doi.org/10.1016/j.jhydrol.2013.02.017

CHEN, Y., SAMUELSON, H. W., \& TONG, Z. (2016). Integrated design workflow and a new tool for urban rainwater management. $J$ Environ Manage, 180, 45-51. http://doi.org/10.1016/j.jenvman.2016.04.059

CHIEW, F. H. S., \& MCMAHON, T. A. (1999). Modelling runoff and diffuse pollution loads in urban areas. Water Science and Technology, 39(12), 241-248. http://doi.org/10.1016/S0273-1223(99)00340-6

CHUI, T. F. M., LIU, X., \& ZHAN, W. (2016). Assessing cost-effectiveness of specific LID practice designs in response to large storm events. Journal of Hydrology, 533, 353-364. http://doi.org/10.1016/j.jhydrol.2015.12.011

Computational Hydraulics International (CHI), (2007). Development of Automated Radar Acquisition and Processing Tools for Hydrologic Modelling in Flood Forecasting. Report prepared for the Toronto and Region Conservation Authority (TRCA), Toronto, Ontario, p. R229.

DIETZ, M. E., \& CLAUSEN, J. C. (2008). Stormwater runoff and export changes with development in a traditional and low impact subdivision. Journal of Environmental Management, 87(4), 560-566. http://doi.org/10.1016/j.jenvman.2007.03.026

DUDULA, J., \& RANDHIR, T. (2016). Modeling the influence of Climate Change on Watershed Systems: Adaptation through. Journal of Hydrology. http://doi.org/10.1016/j.jhydrol.2016.07.020

ELLIOTT, A. H., \& TROWSDALE, S. A. (2007). A review of models for low impact urban stormwater drainage. Environmental Modelling and Software, 22(3), 394-405. http://doi.org/10.1016/j.envsoft.2005.12.005

FRIEDL, F., MÖDERL, M., RAUCH, W., LIU, Q., SCHROTTER, S., \& FUCHSHANUSCH, D. (2012). Failure propagation for large-diameter transmission water mains using dynamic failure risk index. In World environmental and water resources congress. American Society of Civil Engineers (ASCE), Albuquerque..

GALAVOTI, R. C., VASCONCELlOS, A. F., JR, A. O., ANDRADE, J. P. M. DE, DE, P., NETO, A., ... MENDIONDO, E. M. (2010). Sustainable Handling of the River Basin / River / Floodplain System for the Conservation of Water Resources in Urban Areas Gestion durable du système bassin versant / rivière / plaine $\mathrm{d}$ ' inondation pour la conservation des ressources en eau dans les zone, 1-10.

GHODSI, S. H., KERACHIAN, R., \& ZAHMATKESH, Z. (2016). A multi-stakeholder framework for urban runoff quality management: Application of social choice and bargaining techniques. Science of the Total Environment, 550, 574-585. http://doi.org/10.1016/j.scitotenv.2016.01.052

HOUDEShEL, C. D., HUltiNE, K. R., JOHNSON, N. C., \& POMEROY, C. A. (2015). Evaluation of three vegetation treatments in bioretention gardens in a semi-arid climate. Landscape $\quad$ and $\quad$ Planning, 62-72. http://doi.org/10.1016/j.landurbplan.2014.11.008

JAMES, W. (1985). PCSWMM User Manual Runoff Module. 
JOKSIMOVIC, D., \& ALAM, Z. (2014). Cost efficiency of Low Impact Development (LID) stormwater management practices. Procedia Engineering, 89(Lid), 734-741. http://doi.org/10.1016/j.proeng.2014.11.501

KAUSHAL, S.S., BELT, K.T., (2012). The urban watershed continuum: evolving spatial and temporal dimensions. Urban Ecosyst. 15, 409-435.

KLENZENDORF, B., PORESKY, A., KELLY, M., \& CHRISTMAN, M. (2015). Mitigation in Austin, Texas, 1-10.

LABARRE, W. J., OWNBY, D. R., LEV, S. M., RADER, K. J., \& CASEY, R. E. (2016). Attenuation of copper in runoff from copper roofing materials by two stormwater control measures. Water Research, 88, 207-215. http://doi.org/10.1016/j.watres.2015.10.009

LIM, H. S., \& LU, X. X. (2016). Sustainable urban stormwater management in the tropics: an evaluation of Singapore's ABC Waters Program. Journal of Hydrology, 538, 842-862. http://doi.org/http://dx.doi.org/10.1016/j.jhydrol.2016.04.063

LIU, A., GOONETILLEKE, A., \& EGODAWATTA, P. (2012). Taxonomy for rainfall events based on pollutant wash-off potential in urban areas. Ecological Engineering, 47(October), 110-114. http://doi.org/10.1016/j.ecoleng.2012.06.008

LIU, Y., CIBIN, R., BRALTS, V. F., CHAUBEY, I., BOWLING, L. C., \& ENGEL, B. A. (2016). Optimal selection and placement of BMPs and LID practices with a rainfallrunoff model. Environmental Modelling and Software, 80, 281-296. http://doi.org/10.1016/j.envsoft.2016.03.005

LOC, H. H., BABEL, M. S., WEESAKUL, S., IRVINE, K. N., \& DUYEN, P. M. (2015). Exploratory Assessment of SUDS Feasibility in Nhieu Loc-Thi Nghe Basin, Ho Chi Minh City, Vietnam. British Journal of Environment and Climate Change, 5(2), 91-103. http://doi.org/10.9734/BJECC/2015/11534

LUCAS, W. C., \& SAMPLE, D. J. (2015). Reducing combined sewer overflows by using outlet controls for Green Stormwater Infrastructure: Case study in Richmond, Virginia. Journal of Hydrology, 520, 473-488. http://doi.org/10.1016/j.jhydrol.2014.10.029

MACEDO, M. B.. ; ROSA, A. MENDIONDO, E. M. ; de SOUZA, V. C. B. Otimização da eficiência de técnicas compensatórias de bioretenção em clima subtropical. XXI Simpósio Brasileiro de Recursos Hídricos, Novembro, 2015.

MANGANGKA, I. R., LIU, A., EGODAWATTA, P., \& GOONETILLEKE, A. (2015). Performance characterisation of a stormwater treatment bioretention basin. Journal of Environmental Management, $150, \quad 173-178$. http://doi.org/10.1016/j.jenvman.2014.11.007

MELBOURNEWATER (2003) WSUD Technical Manual Scoping Study. Disponível em http://www.melbournewater.com.au/content/library/wsud/wsud_technical_manual.pdf. Acesso em outubro de 2012.

MElorose, J., PERROY, R., \& CAREAS, S. (2015). No Title No Title. Statewide Agricultural Land Use Baseline 2015, 1. http://doi.org/10.1017/CBO9781107415324.004

MIKOVITS, C., RAUCH, W., \& KLEIDORFER, M. (2014). Dynamics in urban development, population growth and their influences on urban water infrastructure. Procedia Engineering, 70, 1147-1156. http://doi.org/10.1016/j.proeng.2014.02.127

MORIASI, D. N. ET AL. (2007). Model evaluation guidelines for systematic quantification of accuracy in watershed simulations. Transactions of the ASABE, v. 50, n. 3, p. 885-900.

PALANISAMY, B., \& CHUI, T. F. M. (2015). Rehabilitation of concrete canals in urban catchments using low impact development techniques. Journal of Hydrology, 523, 309319. http://doi.org/10.1016/j.jhydrol.2015.01.034

PENN, C., BOWEN, J., MCGRATH, J., NAIRN, R., FOX, G., BROWN, G., ... GILL, C. (2016). Evaluation of a universal flow-through model for predicting and designing 
phosphorus removal structures. Chemosphere, 151, 345-355. http://doi.org/10.1016/j.chemosphere.2016.02.105

PONGMALA, K., AUTIXIER, L., MADOUX-HUMERY, A. S., FUAMBA, M., GALARNEAU, M., SAUVÉ, S., DORNER, S. (2015). Modelling total suspended solids, E. coli and carbamazepine, a tracer of wastewater contamination from combined sewer overflows. Journal of Hydrology, 531, 839. http://doi.org/10.1016/j.jhydrol.2015.10.042

RANDELOVIC, A., ZHANG, K., JACIMOVIC, N., MCCARTHY, D., \& DELETIC, A. (2016). Stormwater biofilter treatment model (MPiRe) for selected micro-pollutants. Water Research, 89, 180-191. http://doi.org/10.1016/j.watres.2015.11.046

RAWLS, W. J., BRAKENSIEK, D. L., \& SAXTON, K. E. (1982). Estimation of Soil Water Properties. Transactions of the ASAE. http://doi.org/10.13031/2013.33720

RIAÑO-BRICEÑO, G., BARREIRO-GOMEZ, J., RAMIREZ-JAIME, A., QUIJANO, N., \& OCAMPO-MARTINEZ, C. (2016). MatSWMM - An open-source toolbox for designing real-time control of urban drainage systems. Environmental Modelling \& Software, 83, 143-154. http://doi.org/10.1016/j.envsoft.2016.05.009

ROSA, A.; MACEDO, M. B.; SOUZA, V. C. B.; MENDIONDO, E. M. (2015). Learning From Risk-Based SUDS at Changing Subtropical Conditions. New Insights for Sizing Stormwater Treatment Practices Using Experimental Layouts in Brazil. International conference on Water, Megacities and global change - 2015 December 1st - 4th 2015 at UNESCO HQ - Paris - France.

ROSA, A.; MACEDO, M. B.; SOUZA, V. C. B.; MENDIONDO, E. M. (2016). Validating new insights for sizing stormwater of treatment practices using an own computational model compared to HEC HMS. 9th International conference NOVATECH - 2016 June 28 to July 1. Lyon - France.

SABOURI, F., GHARABAGHI, B., MAHBOUBI, A. A., \& MCBEAN, E. A. (2013). Impervious surfaces and sewer pipe effects on stormwater runoff temperature. Journal of Hydrology, 502, 10-17. http://doi.org/10.1016/j.jhydrol.2013.08.016

SABOURI, F., GHARABAGHI, B., SATTAR, A. M. A., \& THOMPSON, A. M. (2016). Event-based stormwater management pond runoff temperature model. Journal of Hydrology, 540, 306-316. http://doi.org/10.1016/j.jhydrol.2016.06.017

SHINMA, T. A. (2011). Multiobjective calibration of SWMM applied to rainfall-runoff transformation. M.Sc. Dissertation. School of Engineering at São Carlos, University of São Paulo, São Carlos, Brazil Retrieved from http://www.teses.usp.br/teses/disponiveis/18/18138/tde-18072011-135212/pt-br.php.1

SMITH, D., LI, J., \& BANTING, D. (2005). A PCSWMM/GIS-based water balance model for the Reesor Creek watershed. Atmospheric Research, 77(1-4 SPEC. ISS.), 388-406. http://doi.org/10.1016/j.atmosres.2004.12.010

SOVANN, C., IRVINE, K., SUTHIPONG, S., KOK, S., \& CHEA, E. (2015). Dynamic Modeling to Assess Natural Wetlands Treatment of Wastewater in Phnom Penh, Cambodia: Towards an Eco-City Planning Tool. British Journal of Environment and Climate Change, 5(2), 104-115. http://doi.org/10.9734/BJECC/2015/12101

TALBOT, M., MCGUIRE, O., OLIVIER, C., \& FLEMING, R. (2016). Parameterization and Application of Agricultural Best Management Practices in a Rural Ontario Watershed Using PCSWMM. Journal of Water Management Modeling, 1-10.

TILLINGHAST, E. D., HUNT, W. F., \& JENNINGS, G. D. (2011). Stormwater control measure (SCM) design standards to limit stream erosion for Piedmont North Carolina. Journal of Hydrology, 411(3-4), 185-196. http://doi.org/10.1016/j.jhydrol.2011.09.027

TOBERGTE, D. R., \& CURTIS, S. (2013). No Title No Title. Journal of Chemical Information and Modeling, 53(9). 
ROON, M. (2007). Water localisation and reclamation: Steps towards low impact urban design and development. Journal of Environmental Management, 83(4), 437-447.

ROSSMAN, L.A., (2004). Storm Water Management Model User's Manual, Version 5.0, Cincinatti, $\mathrm{OH}$.

SAMPLE, D. J., GRIZZARD, T. J., SANSALONE, J., DAVIS, A. P., ROSEEN, R. M., \& WALKER, J. (2012). Assessing performance of manufactured treatment devices for the removal of phosphorus from urban stormwater. Journal of Environmental Management.

SAMPLE, D. J., \& LIU, J. (2014). Optimizing rainwater harvesting systems for the dual purposes of water supply and runoff capture. Journal of Cleaner Production, 75, 174 194. http://doi.org/10.1016/j.jclepro.2014.03.075

ZAFFANI, A. G. (2012). Diffuse Pollution from Urban Drainage based on ecohydrology: Diagnosis and Long Term Scenarios in Urban Watershed in São Carlos, SP. M.Sc. Dissertation. School of Engineering at São Carlos, University of São Paulo, São Carlos, Brazil.

ZHANG, K., RANDElOVIC, A., DELETIC, A., PAGE, D., \& MCCARTHY, D. T. (2016). Stormwater biofilters: A new validation modelling tool. Ecological Engineering, 87, 5361. http://doi.org/10.1016/j.ecoleng.2015.11.014

ZOPPOU, C. (2001). Review of urban storm water models. Environmental Modelling and Software, 16(3), 195-231. http://doi.org/10.1016/S1364-8152 
APPENDIX A - Plotted graphs for washoff IN

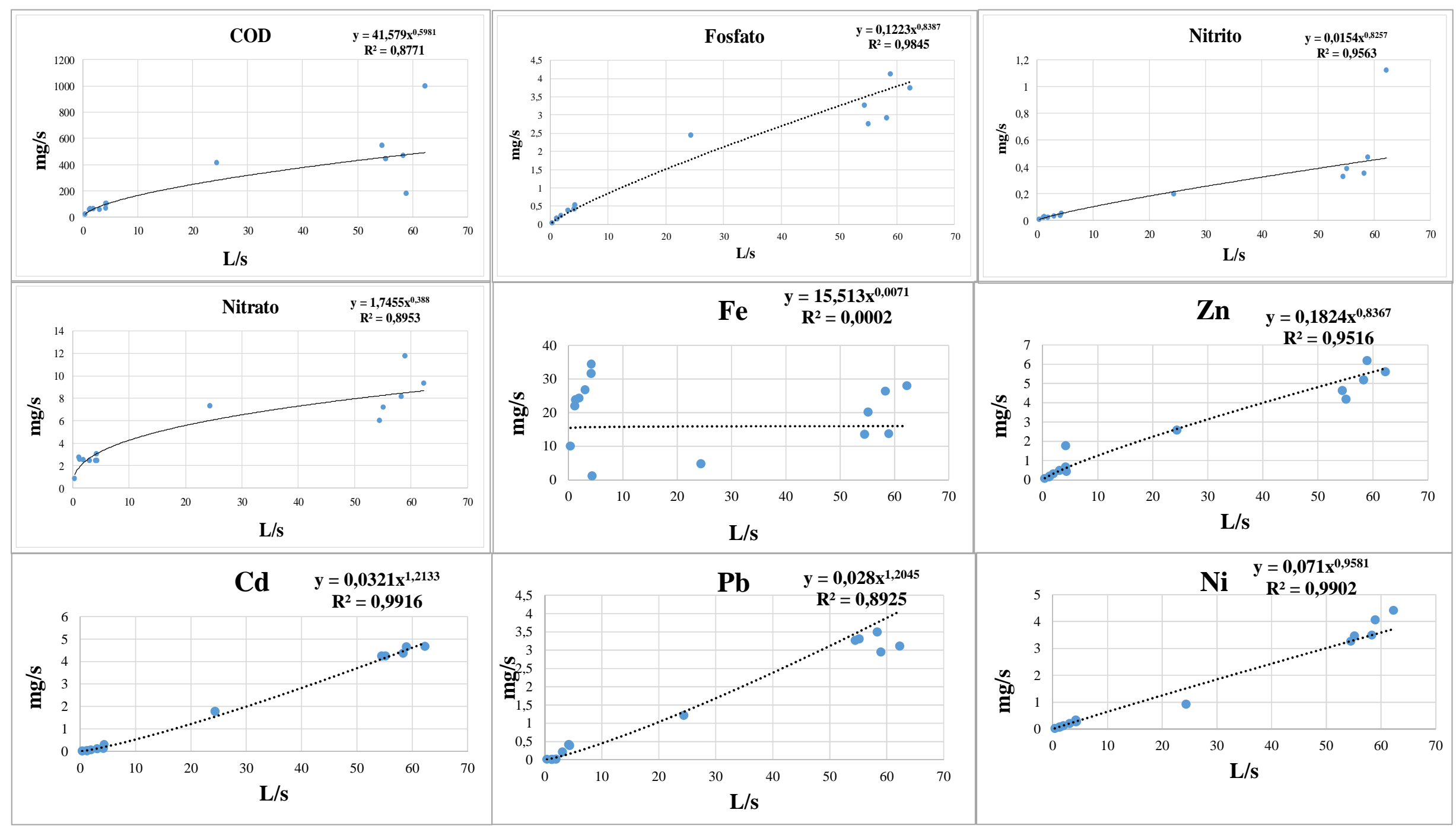


APPENDIX B - Plotted graphs for washoff OUT
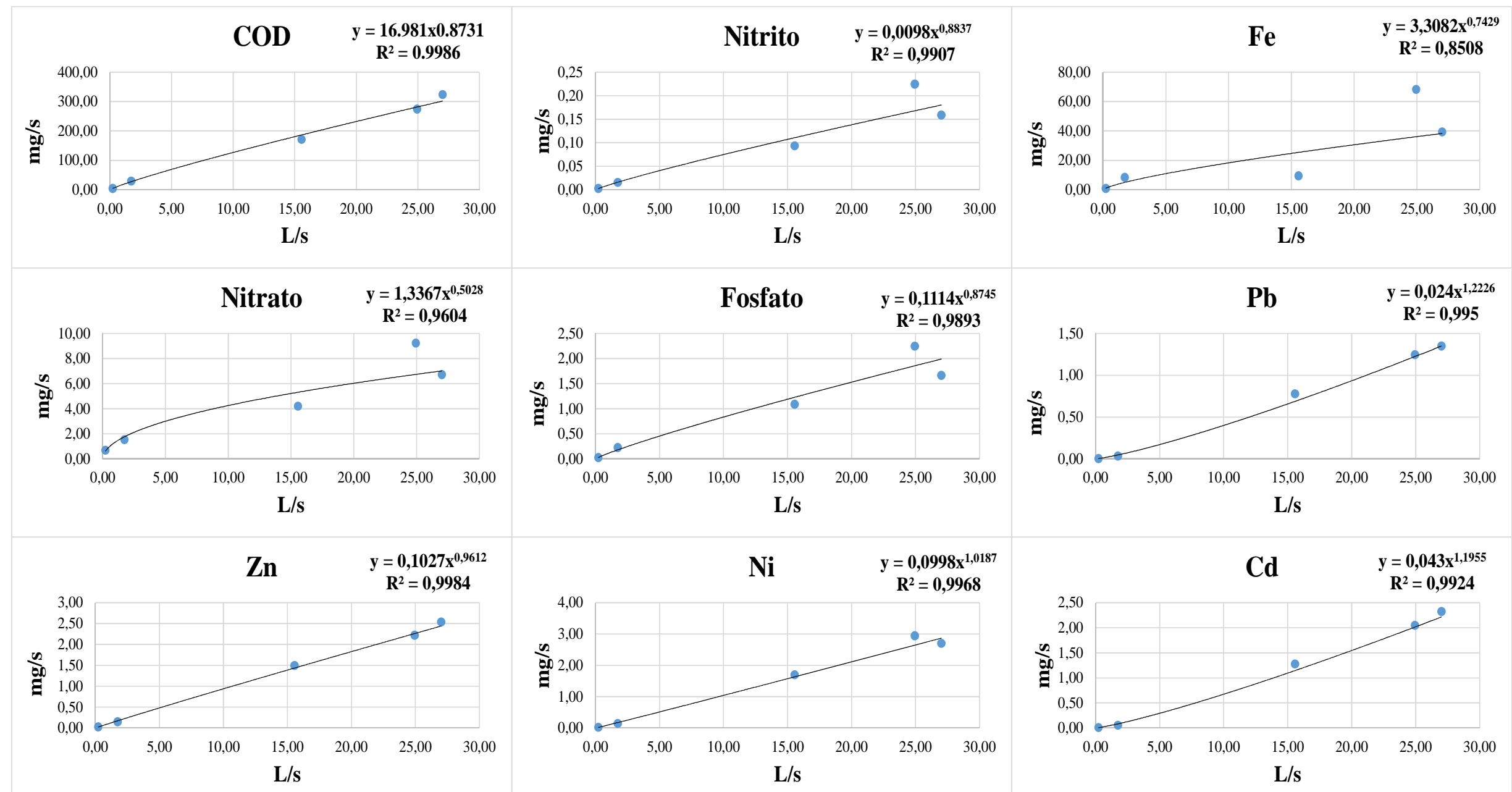
APPENDIX C - Table of parameters values were used for the calibration

\section{PARAMETER}

X-Coordinate

Y-Coordinate

Area (ha)

Width (m)

Slope $(\%)$

Imperv. $(\%)$

$\mathrm{N}$ Imperv

N Perv

Dstore Imperv (mm)

Dstore Perv (mm)

Zero Imperv (\%)

Suction Head (mm)

Conductivity $(\mathrm{mm} / \mathrm{hr})$

Initial Deficit (frac.)

K

C

$\mathrm{P}$

LS

Evaporation (mm)

Berm height $(\mathrm{mm})$

Vegetative Cover (fraction)

Surface roughness (Manning's n)

Soil Thickness (mm)

Porosity (volume fraction)

Field capacity (volume fraction)

Wilting point (volume fraction)

Soil Conductivity $(\mathrm{mm} / \mathrm{hr})$

Conductivity slope

Suction Head (mm)

Storage Height (mm)

Storage Void Ratio (voids / solids)

Storage Conductivity $(\mathrm{mm} / \mathrm{hr})$
LID1

$$
-5.335 .357 .475
$$$$
-2.511 .792 .284
$$

0.0061

11

0.001

0

0

0.6

2.5

5

0

170

400

6

0.4

0.1

0.75

1.91

4.99

300

0.1

0.45

700

0.5

0.2

0.05

11415

40

70

1000

0.4

870

CONTRIBUTION AREA

$-5.335 .451 .648$

$-2.511 .799 .704$

2.37

240

3

25

0.05

0.3

0.1

0.2

0

170

6

6

0.4

0.1

0.75

1.91

4.99
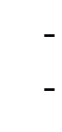


\section{GENERAL CONCLUSION}

The conclusion will be presented in the form of answers to the proposed objectives and, subsequently, a section of recommendations for future works.

The research objective is to study the generalized efficiency of combined detention and bioretention compensatory techniques to control diffuse pollution, with the introduction of new experiments coupled to long-term adaptation strategies for qualitative and quantitative urban drainage aspects based on ecohydrology.

On the one hand, this thesis suggests that compensatory techniques can be used not only for evaluation of the impacts of diffuse pollution from urban drainage, but also as a way of contributing to the sustainability of watersheds, favouring the maintenance of the hydrological cycle, and, consequently, of the cycling of water bodies. On the other hand, the thesis also presents theoretical, practical and model examples of how compensatory techniques can also be approached as in-site, local long-term adaptation and mitigation strategies for qualitative and quantitative risks linked to urban drainage. Thus, CTs, as engineered devices under the concept of Sustainable Urban Drainage Systems would hit multi-purpose targets reaching out a great variety of stakeholders.

One specific objective is "To discuss the scope and limitations of sizing methodologies and criteria and evaluate the efficiency of compensatory measures in the control of urban drainage quantity and quality". Across the Thesis is clearly depicted how scopes and limits of the up-to-date sizing methodologies and criteria introduce a great range of outputs. Contrasting methods of addressing CT's efficiency changes alter projects, budgets and people's experience. Thus, different CT's sizing criteria perform a real gap of knowledge that: (1) directly impacts on the physical and cost of the nature of CTs, and (2) inherently exerts and prioritizes bias on forthcoming plans of operation and maintenance during the CT's lifetime to maintain a minimum, but theoretical, efficiency.

The quali-quantitative efficiency of methods proposed in specialized literature were compared with the model performance proposed in this Thesis, making this as innovative research by presenting the modular sizing system and the future scenarios simulation to improve the use of compensatory techniques on drainage management in urban scenarios.

Therefore, the Thesis assumes that this gap of knowledge must be analyzed with a deeper discussion on the worldwide state-of-the-art nomenclature of terms, approaches, techniques and research groups on SUDS. Then, the Thesis' second chapter presents the technique of bibliometrics, an innovative and multidisciplinary tool in the area of engineering, 
for the survey of bibliographic data, construction of databases and guidance for research of bioretention and CTs. Cognitive and relative maps of authors and techniques also show that still: (1) neither complete standards, nor norms are completely gathered among worldwide research groups, which have interesting high auto-citation or indexing, and (2) local scales, contexts and knowledge are crucial factors affecting a priori the assumptions for whichever sizing of CT`s and even global vision of SUDS.

The set of 22 themes presented in this research and related to SUD, involved researchers from 82 countries, 2,027 research centers and 8,237 authors interacting through 11,857 citation relationships. In this domain, $72 \%$ of the relationships occurred between authors from European and North American countries. The topics most widely used in the academic community are Stormwater management, Low impact development, integrated Urban water management, Bioretention and best management practice.

The second specific objective of this thesis is to evaluate the applicability of ecohydrological indicators in the generalized evaluation of the efficiency of compensation mechanisms for the quantity and quality of water.

Through the fourth chapter and, based on the legal framework and ecohydrological indicators using geoprocessing tools, it was possible to evaluate proper areas to implement the bioretention techniques, evaluating the impacts of urban growth through maps of land use and occupation. It also helped to choose the area for the constructions of the bioretention system. After the construction of the system, it is proven by the results of quali-quantitative limits that the system can corroborate (help) with the sustainability of Mineirinho's river basin. Besides that, the construction of compensatory techniques to treat diffuse pollution provided with drainage systems which are planned considering ecohydrology indicators, is also revealed as a promising mechanism for maintaining urban watersheds.

As the third specific objective, which is to study experimentally, in the micro drainage pilot devices, the detention effects combined with bioretention, including design, sizing, installation, monitoring, modeling and efficiency analysis during the lifetime of the devices.

One of the greatest challenges faced when coming to CT's is the integration between runoff quantitative, qualitative performance and sizing methodology. This Thesis presents on its third chapter a sizing methodology for bioretention systems, called BIRENICE and its performance compared with HEC -HMS model.

It is proved, by the results found in the comparison between the sizing method of bioretention proposed systems, BIRENICE and HEC-HMS that the proposed method is 
efficient, based on the presented results of the quali-quantitative parameters. It is innovative, because it is planned and executed considering the modulation by predicting the growth and development of the areas in question and, through the simulation of dimensioning, the extension of the proposed systems, making it applicable to the conditions of urban drainage, which can be adapted to other realities.

The last specific objective is simulating long-term adaptation scenarios to compare the effects of combined detention and bioretention devices of macro-drainage on the selected critical watersheds.

In this step of the research (the fifth chapter), the focus is to evaluate the performance of a bioretention system and to simulate long-term scenarios using a PCSWMM model. The simulation model PCSWMM has a quick and concise manner of using its interface, allowing the user to have instant access to calibration components of the SWMM 5, providing an effective calibration for the aspects used in the preparation of future scenarios. Through the fifth chapter, it is possible to conclude, that the employment of PCSWMM tool for simulation of future scenarios is efficient for any proposed adjustments in CT, considering the changes in land use and occupation for future scenarios. The PCSWMM stands out as an important model for simulation and a tool for managing water resources for decision making. Comparing the results of quality and quantity efficiency, it can be noticed that even though there is an efficiency variation between scenarios, it remained satisfactory, between $81,8 \%$ and $91,2 \%$ in the simulated scenarios.

By the experience obtained with this research together with the experimental results found by monitoring of compensatory techniques, it was possible to evaluate the control of diffuse pollution parameters in micro drainage and its computational modelling of qualiquantitative aspects, which were considered in this study. However, it is noted that there are still some gaps while inserting these types of technologies: (I) methods for generalized dimensioning; (II) lack of experimental data; (III) needs maintenance and enhancement of meteorological monitoring network; (IV) bureaucratic matters, involving the construction of the experiment in the Brazilian territory.

Through experience, it is possible to conclude that compensatory techniques of bioretention are promising alternatives to corroborate witch the water resources management, mainly in relation to the quantitative and qualitative aspects of water from the diffuse pollution of urban drainage caused by floods in urban centers. 


\section{Recommendations for Future Researches}

Through the experience obtained during this thesis, it was possible to make some recommendations for future work:

- Studying the methodology of sizing that considers what you want to monitor;

- Knowledge of the proper technique to be implemented;

- Characterization of the soil;

- Detailed knowledge of the existing drainage system;

- Reliable delimitation of the area of assistance;

- Construction in periods of drought;

- Depending on the used technique, implementation of drains for draining the excess flow;

- Planting vegetation as soon as the construction is finished;

- Choice of vegetation that contributes to the quality aspects;

- Access to topographic maps and details of land use and occupation;

- Detailed planning of the monitoring to be carried out;

- Monitoring type to be employed;

- Using proper equipment;

- Need or inclusion of quality/quantity parameters in monitoring;

- Consider monitoring of precipitation in all events;

- Analyze the possibility of water reuse. 